JULIANA DE PAULA MARTINS

EVOLUÇÃO DA MICROESTRUTURA E DA TEXTURA DURANTE O PROCESSAMENTO DE CHAPAS DA LIGA Al-Mn-Fe-Si (3003) PRODUZIDAS POR LINGOTAMENTO CONTÍNUO: UM ESTUDO COMPARATIVO COM O PROCESSO SEMI-CONTÍNUO.

Tese apresentada à Escola Politécnica da Universidade de São Paulo para obtenção do Título de Doutor em Engenharia.

São Paulo 
JULIANA DE PAULA MARTINS

\section{EVOLUÇÃO DA MICROESTRUTURA E DA TEXTURA DURANTE O PROCESSAMENTO DE CHAPAS DA LIGA Al-Mn-Fe-Si (3003) PRODUZIDAS POR LINGOTAMENTO CONTÍNUO: UM ESTUDO COMPARATIVO COM O PROCESSO SEMI-CONTÍNUO.}

Tese apresentada à Escola Politécnica da Universidade de São Paulo para Obtenção do Título de Doutor em Engenharia.

Área de Concentração:

Engenharia Metalúrgica e de Materiais

Orientador:

Prof. Dr. Angelo Fernando Padilha

São Paulo 
Este exemplar foi revisado e alterado em relação à versão original, sob responsabilidade única do autor e com a anuência de seu orientador.

São Paulo, 9 de junho de 2005.

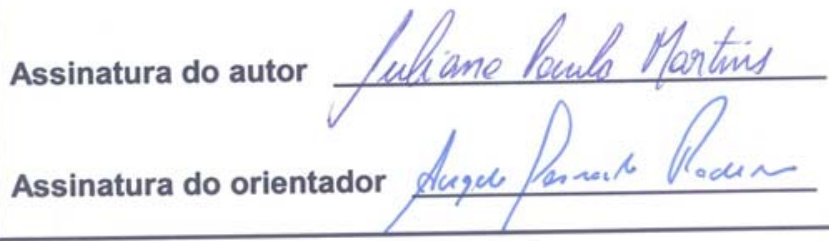

FICHA CATALOGRÁFICA

Martins, Juliana de Paula

Evoluçăo da microestrutura e da textura durante o processamento de chapas da liga Al-Mn-Fe-Si (3003) produzidas por

lingotamento contínuo: um estudo comparativo com o processo semi-contínuo / J.P. Martins. -- ed.rev. -- São Paulo, 2005.

$171 \mathrm{p}$.

Tese (Doutorado) - Escola Politécnica da Universidade de Paulo. Departamento de Engenharia Metalúrgica e de Materiais.

1.Roll caster 2.Alumínio 3.Difração de raios $X$ 4.EBSD I.Universidade de São Paulo. Escola Politécnica Departamento de Engenharia Metalúrgica e de Materiais Il.t. 
À minha mãe e meu irmão cujo amor permite manter minha perseverança. E principalmente ao André Luís pelo constante incentivo e confiança para a realização do presente trabalho. 


\section{AGRADECIMENTOS}

À Fundação de Amparo à Pesquisa do Estado de São Paulo - FAPESP, pela concessão da bolsa de doutorado (Processo ${ }^{\circ}$ 02/03252-6) e suporte financeiro (Processo $n^{\circ}$ 99/10796-8) para a realização deste trabalho;

Ao Prof. Dr. Angelo Fernando Padilha pela convivência e orientação sempre precisa durante o doutorado;

À Companhia Brasileira de Alumínio - CBA, pelo desenvolvimento da parceria de cunho técnico-científico;

Ao MSc. Eng. Ricardo C. Fernandes - CBA, pelo fornecimento do material da liga de alumínio pelo processo "roll caster";

Ao MSc. Eng. Antenor Ferreira Filho, por permitir a utilização de equipamentos da Brasmetal Waelzholz para análise de anisotropia nas chapas provenientes do processo "roll caster";

Ao Prof. Dr.Hugo Ricardo Zschommler Sandim - DEMAR - FAENQUIL pela colaboração prestada na utilização de fornos e microdurômetro;

Ao Prof. Dr. Durval Rodrigues Junior - DEMAR-FAENQUIL pela colaboração prestada nas medidas de resistividade elétrica;

Ao Eguiberto Galego, a MSc. Marilene Morelli Serna e ao Nildemar Aparecido Messias pela colaboração na utilização de equipamentos nos laboratórios de difração de raios $\mathrm{X}$ e de microscopia eletrônica de transmissão do IPEN;

Ao Prof. Dr.Waldemar Alfredo Monteiro - IPEN - por disponibilizar o laboratório de microscopia eletrônica e pela contribuição em interpretação de difração de elétrons;

Ao Prof. Dr. Nelson B. Lima - IPEN- por disponibilizar o laboratório de difração de raios $\mathrm{X}$ e pela convivência durante o doutorado;

Ao técnico Nildemar Torres do Instituto de Química-USP, pela contribuição nas dissoluções químicas para extração de precipitados;

Ao técnico Eliseu Evangelista pela colaboração em preparação metalográfica; Aos colegas da pós-graduação e funcionários do Departamento de Engenharia Metalúrgica e de Materiais da EPUSP, que de uma forma direta ou indiretamente, na troca de informações e discussões contribuíram com o enriquecimento deste trabalho. 


\section{SUMÁRIO}

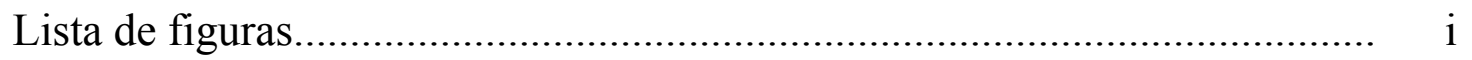

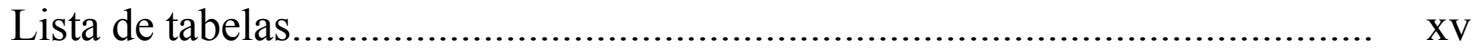

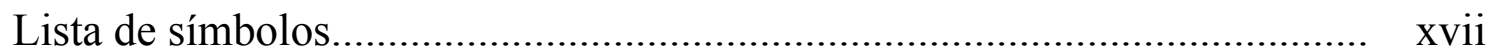

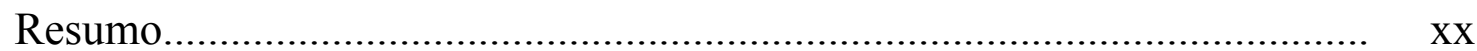

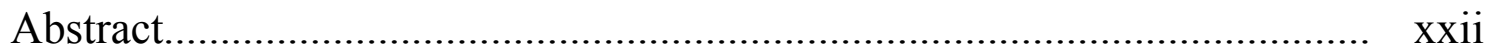

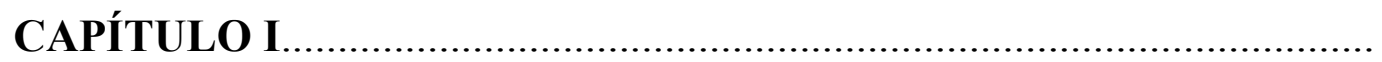

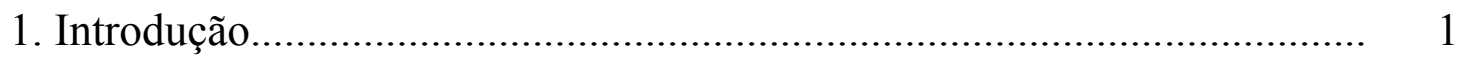

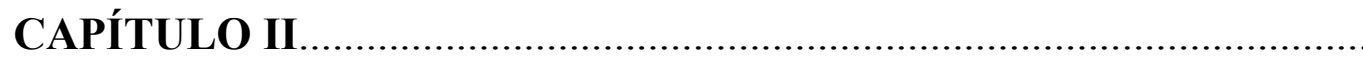

2. Revisão da literatura.............................................................................

2.1 - A indústria de alumínio no Brasil........................................................... 3

2.2 - Propriedades e aplicações da liga 3003 .......................................................... 5

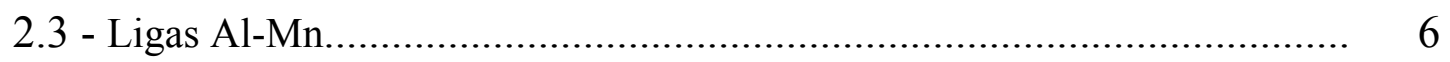

2.3.1 - Processo de solidificação........................................................................ 8

2.3.2 - Homogeneização.......................................................................... 9

2.4 - Processo roll caster....................................................................... 14

2.5 - Deformação, recristalização e precipitação em ligas Al-Mn............... 16

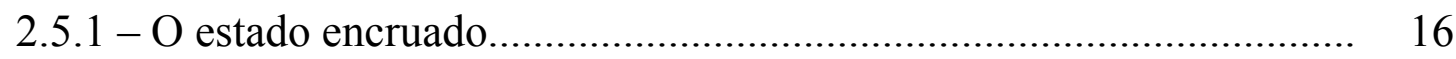

2.5.2 - Recuperação............................................................................... 20

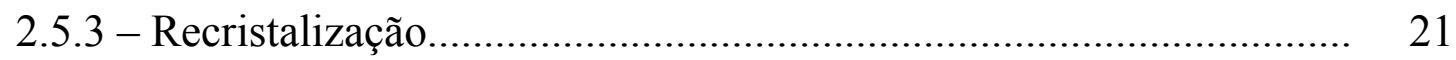

2.5.3.1 - Nucleação.............................................................................. 22 
2.5.3.2 - Crescimento de novos grãos na recristalização.............................. 24

2.5.3.3 - Influência das partículas durante recristalização............................ 26

2.5.3.4 - Precipitação durante recristalização.............................................. 27

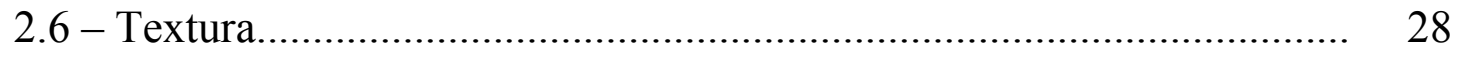

2.6.1 - Análise da macrotextura............................................................. 31

2.6.2 - Análise da microtextura............................................................. 33

2.6.3 - Figura de pólo............................................................................. 38

2.6.4 - Função distribuição de orientação.................................................... 40

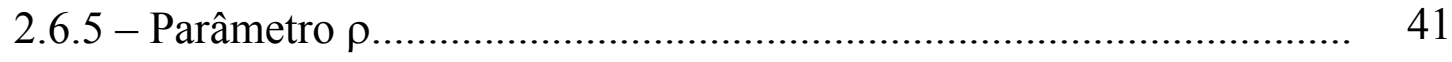

2.6.6 - Textura de laminação...................................................................... 42

2.6.7 - Textura de recristalização............................................................. 43

2.7 - Difração de elétrons............................................................................ 45

\section{CAPÍTULO III}

3 Materiais e métodos................................................................... 51

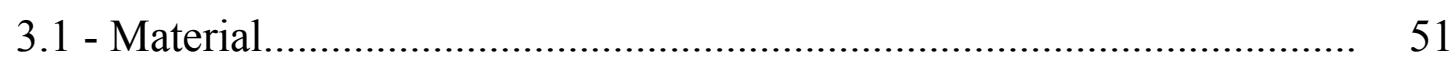

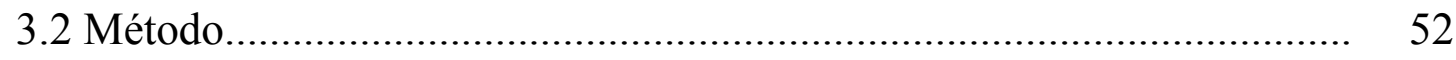

3.2.1 - Microscopia óptica.................................................................... 53

3.2.2 - Microscopia eletrônica de varredura................................................ 53

3.2.3 - Microscopia eletrônica de transmissão............................................. 54

3.2.4 - Extração de precipitados................................................................... 54

3.2.4.1 - Método da dissolução química........................................................ 55

3.2.4.2 - Método da dissolução eletrolítica..................................................... 55 
3.2.5. - Difração de raios X para determinação da textura............................ 56

3.2.6 - Metalografia quantitativa............................................................ $\quad 56$

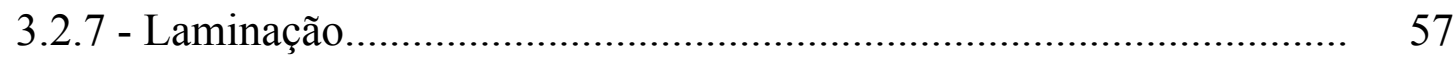

3.2.8 - Tratamentos térmicos.......................................................... 58

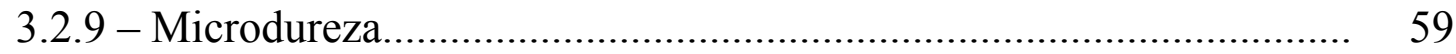

3.2.10 - Resistividade elétrica............................................................. 59

3.2.11 - Condutividade elétrica................................................................ 59

CAPÍTULO IV.

4 - Resultados e discussão dos resultados.................................................... 61

4.1 - Caracterização microestrutural inicial das amostras provenientes dos processos caster e laminada a quente................................................ 61

4.2 - Análise comparativa de textura resultante dos processos caster e

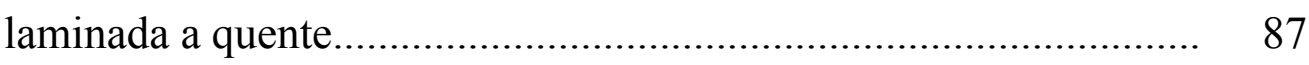

4.3 - Microestrutura e textura de laminação a frio de chapas provenientes do processo caster................................................................... 101

4.4 - Microestrutura, textura e microtextura de recristalização de chapas provenientes do processo caster..................................................... 106

4.5 - Estudo do efeito do tratamento térmico prévio de homogeneização no encruamento e na posterior recristalização de chapas provenientes do processo caster

4.6 - Comparação entre as técnicas de EBSD e de difração de raios X........ 130

4.7 - Técnicas de extração de precipitados.................................................... 133

4.7.1 - Método da dissolução química.......................................................... 133

4.7.2 - Método da dissolução eletrolítica..................................................... 138 
4.8 - Estudo da transformação do precipitado $\mathrm{Al}_{6} \mathrm{Mn}$ durante tratamentos de homogeneização....................................................................... 142

4.8.1. Caracterização do tratamento térmico de homogeneização de $500^{\circ} \mathrm{C}$ por $12 \mathrm{~h}$

4.8.2. Evolução da transformação de fase ao longo do tempo

CAPÍTULO V.

5 - Conclusões.

\section{CAPÍTULO VI.}

6 - Referências bibliográficas. 


\section{LISTA DE FIGURAS}

Figura 1 - Diagrama de fases de equilíbrio (superfície liquidus) do sistema Al$\mathrm{Mn}-\mathrm{Si}$

Figura 2 - Porcentagem da fase $\alpha-\mathrm{Al}(\mathrm{Mn}, \mathrm{Fe}) \mathrm{Si}$, em relação ao total de partículas primárias, durante aquecimento.

Figura 3 - Variações da fração em área e da densidade de partículas primárias (número de partículas $/ \mathrm{mm}^{2}$ ) durante homogeneização a $600^{\circ} \mathrm{C}$.

Figura 4 - Razão Mn / (Mn + Fe) (em \% peso / \% peso) de partículas primárias durante homogeneização.

Figura 5 - Desenho esquemático do processo TRC horizontal

Figura 6: Arranjos esquemáticos de discordâncias geometricamente necessárias formadas ao redor de precipitados durante a deformação plástica.

Figura 7 - Desenho esquemático mostrando o sentido de migração do contorno de grão e de átomos para que ocorra a recristalização.

Figura 8 - Ordem de ocorrência da recristalização e precipitação em ligas supersaturadas. (a) Diagrama de fases esquemático de liga de concentração $\mathrm{C}_{0}$ solubilizada e deformada a temperatura ambiente no estado supersaturado. (b) Curva TTT envolvendo precipitação e recristalização.

Figura 9 - Desenho esquemático ilustrando a relação entre macrotextura, microtextura e mesotextura. A macrotextura representa a orientação da 
amostra, a microtextura representa a orientação do grão em uma pequena área, neste caso 15 grãos com 3 orientações diferentes e a mesotextura onde, por exemplo, 3 tipos de contornos são indicados.

Figura 10 - Categorização das principais técnicas para determinação da textura de acordo com a técnica de difração usada.

Figura 11 - Goniômetro de textura de geometria de reflexão

Figura 12 - Desenho esquemático ilustrando o sistema de detecção das figuras de difração de elétrons retroespalhados.

Figura 13 - Desenho ilustrativo da formação dos cones de difração

Figura 14 - Linhas de Kikuchi geradas por uma amostra de tântalo laminada até $70 \%$ de redução; a) imagem capturada na tela fosforescente, b) linhas de Kikuchi indexadas pelo software.

Figura 15 - Identificação do posicionamento das linhas de Kikuchi a partir da identificação dos pontos claros e escuros na imagem do espaço de Hough.

Figura 16 - a) Família de pólos $\{001\}$ em cristal cúbico projetado na esfera de referência de projeção estereográfica; b) Figura de pólo de um cristal.

Figura 17 - Figura de pólo inversa: a) projeção estereográfica; b) figura de pólo inversa com identificações de algumas orientações.

Figura 18 - Seções da FDO mostrando a localização das orientações $\{011\}<100>$ (cujo símbolo na figura é ${ }^{\circ}$ ) e $\{111\}<112>$ (cujo símbolo na figura é $\bullet$ ) 
comumente encontradas em metais com estrutura cúbica

Figura 19 - Desenho esquemático da textura de laminação num material hipotético: a) estado inicial; b) laminado Observar apenas a direção dos cristais no material hipotético, pois na realidade os grãos, após laminação, encontram-se alongados na direção de laminação e o número de grãos não diminuem conforme está mostrando o desenho esquemático.

Figura 20 - A amostra, feixe transmitido, feixe difratado e o padrão de difração. A sobreposição da construção da esfera de Ewald no espaço recíproco descreve o padrão de difração.

Figura 21 - a) Reflexão no ângulo $\theta$ de Bragg de planos de cristais em amostra finas em microscópio eletrônico de transmissão; b) A relação entre feixes incidentes, transmitidos e difratados.

Figura 22 - a) Feixe difratado por átomos situados na posição O e L na amostra;

b) Diagrama vetorial descrevendo o processo de difração.

Figura 23 - Diagrama vetorial no espaço recíproco mostrando a reflexão do plano cristalino (hkl).

Figura 24 - a) Microestrutura na seção transversal da amostra caster (bruta de fundição); b) Microestrutura na seção longitudinal da amostra caster (bruta de fundição). Amostra anodizada com solução contendo ácido fluobórico. Microscopia óptica sob luz polarizada. Direção de laminação paralela à direção horizontal......

Figura 25 - Microestrutura da superfície da amostra caster (bruta de fundição). Amostra anodizada com solução contendo ácido fluobórico. Microscopia óptica sob luz polarizada. Direção de laminação paralela à 
direção horizontal

Figura 26 - Microestrutura mostrando a distribuição dos grãos na amostra caster ao longo da espessura, microscopia óptica sob luz polarizada: a) região central; b) região $1 / 4$ da espessura. Amostra anodizada com solução contendo ácido fluobórico. Direção de laminação paralela à direção horizontal.

Figura 27 - a)Microestrutura da amostra caster na região central, microscopia óptica sob luz polarizada; b)Mesma região mostrada em a, microscopia óptica sem luz polarizada. Amostra anodizada com solução contendo ácido fluobórico. Direção de laminação paralela à direção horizontal......

Figura 28 - a)Microestrutura da amostra caster na região $1 / 4$ da superfície, microscopia óptica sob luz polarizada; b)Mesma região mostrada em a, microscopia óptica sem luz polarizada. Amostra anodizada com solução contendo ácido fluobórico. Direção de laminação paralela à direção horizontal

Figura 29 - Caster bruta de fundição, 1/2 da espessura. Exemplos de imagens obtidas por microscopia óptica em campo escuro. Aumento de $1000 \mathrm{X}$. Amostra atacada com solução contendo ácido fluorídrico

Figura 30 - Caster bruta de fundição, 1/4 da espessura. Exemplos de imagens obtidas por microscopia óptica em campo escuro. Aumento de $1000 \mathrm{X}$. Amostra atacada com solução contendo ácido fluorídrico.

Figura 31 - Caster bruta de fundição, superfície. Exemplos de imagens obtidas por microscopia óptica em campo escuro. Aumento de $1000 \mathrm{X}$. Amostra atacada com solução contendo ácido fluorídrico

Figura 32 - Distribuição do tamanho médio de precipitados da amostra caster...... 
Figura 33: Imagens de elétrons retroespalhados obtidas no microscópio eletrônico de varredura: a) superfície, aumento $1000 \mathrm{X}$; b) superfície, aumento $5000 \mathrm{X}$; c) centro, aumento $1000 \mathrm{X}$; d) centro, aumento $5000 \mathrm{X}$. Ataque em solução de ácido fluorídrico.

Figura 34 - Amostra caster atacada com solução de iodo e metanol por 12 h, microscopia eletrônica de varredura, elétrons secundários.

Figura 35 - Amostra caster atacada com solução de iodo e metanol por 12 horas, microscopia eletrônica de varredura, elétrons secundários.

Figura 36 - Microestrutura da amostra caster revelando a presença de subgrãos, microscopia eletrônica de transmissão. Amostra afinada eletroliticamente com solução contendo ácido perclórico.

Figura 37 - Microestrutura da amostra caster revelando a presença de discordâncias no interior do subgrão, microscopia eletrônica de transmissão. Amostra afinada eletroliticamente com solução contendo ácido perclórico.

Figura 38 - Microestrutura da amostra caster revelando a presença de precipitados nos subgrãos, microscopia eletrônica de transmissão. Amostra afinada eletroliticamente com solução contendo ácido perclórico.

Figura 39 - Microestrutura da amostra caster revelando a presença de muitos precipitados retangulares $\left(\mathrm{Al}_{6} \mathrm{Mn}\right)$, microscopia eletrônica de transmissão. Amostra afinada eletroliticamente com solução contendo ácido perclórico.

Figura 40 - Microestrutura da amostra caster revelando a presença de dispersóides, microscopia eletrônica de transmissão. Amostra afinada 
eletroliticamente com solução contendo ácido perclórico

Figura 41 - Difração de elétrons de um precipitado $\mathrm{Al}_{6} \mathrm{Mn}$ encontrado na amostra caster. A direção do feixe de elétrons está indicada na micrografia.

Figura 42 - Micrografia da amostra laminada a quente superfície, microscopia óptica sob luz polarizada. Amostra anodizada com solução contendo ácido fluobórico. Direção de laminação paralela à direção horizontal......

Figura 43 - Microestrutura da amostra laminada a quente na seção longitudinal, microscopia óptica sob luz polarizada. Amostra anodizada com solução contendo ácido fluobórico. Direção de laminação paralela à direção horizontal.

Figura 44 - a)Micrografia da amostra laminada a quente superfície mostrando detalhe do interior de um grão deformado, microscopia óptica sob luz polarizada; b) mesma região mostrada em a, microscopia óptica sem luz polarizada. Amostra anodizada com solução contendo ácido fluobórico. Direção de laminação paralela à direção horizontal.

Figura 45 - Micrografia da amostra laminada a quente na região 1/2 (ao longo da espessura), microscopia óptica sob luz polarizada. Amostra anodizada com solução contendo ácido fluobórico. Direção de laminação paralela à direção horizontal.

Figura 46 - Micrografia da amostra laminada a quente na região $1 / 4$ da superfície (ao longo da espessura), microscopia óptica sob luz polarizada; b) Micrografia da amostra laminada a quente região $1 / 4$ da superfície, mesma região mostrada em a, microscopia óptica sem luz polarizada. Amostra anodizada com solução contendo ácido fluobórico. Direção de laminação paralela à direção horizontal 
Figura 47 - Precipitados encontrados na amostra laminada a quente, microscopia eletrônica de varredura, elétrons secundários. Amostra atacada com solução contendo ácido fluorídrico.

Figura 48 - Espectro (EDS) do precipitado da Figura 47a

Figura 49 - Espectro (EDS) do precipitado da Figura 47b......

Figura 50 - Subestrutura de liga laminada a quente mostrando subgrãos desenvolvidos que contêm alta densidade de discordâncias em seus interiores, microscopia eletrônica de transmissão. Amostra polida eletroliticamente com solução contendo ácido perclórico.

Figura 51 - Micrografia da amostra laminada a quente mostrando estrutura de subgrãos e presença de dispersóides, microscopia eletrônica de transmissão. Amostra polida eletroliticamente com solução contendo ácido perclórico

Figura 52 - Difração de elétrons da matriz alumínio, na amostra laminada a quente. A direção do feixe de elétrons é indicada na micrografia.

Figura 53 - Componentes de textura de laminação de metais CFC no espaço de Euler em 3D: a fibra $\beta$ entre a componente cobre e latão ("Brass") e a fibra $\alpha$ entre a componente do tipo latão e Goss

Figura 54 - a) FP 200 obtida por difração de raios X da amostra caster na superfície; b) FDO (difração de raios X) da amostra caster na superfície.

Figura 55 - a) FP 111 obtida por difração de raios X da amostra caster na seção $1 / 2$ da espessura; b) FDO (difração de raios X) da região central ( $1 / 2$ da espessura ) da amostra caster.

Figura 56 - a) FP 220 obtida por difração de raios X da amostra caster na seção 1/4 
da espessura; b) FDO (difração de raios X) da região central ( $1 / 4$ da espessura ) da amostra caster.

Figura 57 - Mapeamento de orientações da superfície do caster (EBSD), direção de laminação paralela à direção vertical.

Figura 58 - Figuras de pólo discretas da superfície do caster (EBSD).

Figura 59 - FDO (EBSD) da superfície do caster com simetria triclínica, parâmetro $\rho=89 \%$

Figura 60 - FDO (EBSD) da superfície do caster com simetria ortorrômbica, parâmetro $\rho=89 \%$.

Figura 61 - a) FP 200 obtida por difração de raios X da amostra laminada a quente na superfície; b) FDO (difração de raios X) da superfície da amostra laminada a quente.

Figura 62 - a) FP 200 obtida por difração de raios X da amostra laminada a quente na região $1 / 2$ de espessura; b) FDO (difração de raios X) na região $1 / 2$ da espessura da amostra laminada a quente.

Figura 63 - a) FP 111 obtida por difração de raios X da amostra laminada a quente na região $1 / 4$ da espessura; b) FDO (difração de raios X) na região $1 / 4$ da espessura da amostra laminada a quente.

Figura 64 - Mapeamento de orientações da superfície laminada a quente (EBSD), direção de laminação paralela à direção vertical

Figura 65 - FDO (EBSD) da amostra laminada a quente superfície, parâmetro $\rho=$ $53 \%$. 100

Figura 66 - Micrografias da amostra laminada a frio proveniente do processo 
caster e homogeneizada $\left(500^{\circ} \mathrm{C} / 12 \mathrm{~h}\right)$ com reduções de $67 \%$ (a) e $91 \%$ (b). Seção da superfície da amostra. Amostra anodizada com solução contendo ácido fluobórico. Microscopia óptica sob luz polarizada. Direção de laminação paralela à direção horizontal.

Figura 67 - a) FP 111 obtida por difração de raios X da amostra caster laminada a frio com 67\% de redução; b) FDO (difração de raios X) da amostra caster laminada a frio com $67 \%$ de redução

Figura 68 - a) FP 111 obtida por difração de raios X da amostra caster laminada a frio com 91\% de redução; b) FDO (difração de raios X) da amostra caster laminada a frio com $91 \%$ de redução.

Figura 69 - Microestrutura da amostra caster recristalizada (após 67\% de redução e recozimento a $400^{\circ}$ por 1 hora), microscopia ótica sob luz polarizada. Seção da superfície da amostra. Amostra anodizada com solução contendo ácido fluobórico. Microscopia óptica sob luz polarizada. Direção de laminação paralela à direção horizontal.

Figura 70 - Microestrutura da amostra caster recristalizada (após 91\% de redução e recozimento a $400^{\circ}$ por 1 hora), microscopia ótica sob luz polarizada. Seção da superfície da amostra. Amostra anodizada com solução contendo ácido fluobórico. Microscopia óptica sob luz polarizada. Direção de laminação paralela à direção horizontal.

Figura 71 - a) FP 111 obtida por difração de raios $\mathrm{X}$ da amostra caster recristalizada a $400^{\circ} \mathrm{C} / 1 \mathrm{~h}$ após $91 \%$ de redução; b) FDO (difração de raios X) da amostra caster recristalizada a $400^{\circ} \mathrm{C} / 1 \mathrm{~h}$ após $91 \%$ de redução

Figura 72 - a) FP 200 obtida por difração de raios X da amostra caster recristalizada a $400^{\circ} \mathrm{C} / 1 \mathrm{~h}$ após $67 \%$ de redução; b) FDO (difração de raios X) da amostra caster recristalizada a $400^{\circ} \mathrm{C} / 1 \mathrm{~h}$ após $67 \%$ de 
redução

Figura 73 - Gráfico de fibra $\operatorname{com} \varphi_{2}=0$ e $\phi=0$ : a) $67 \%$ de redução e recristalizada e b) $91 \%$ de redução e recristalizada...

Figura 74 - Análise através de EBSD da amostra caster com 91\% de redução e recristalizada a $400^{\circ} \mathrm{C}$ por 1 hora: a) Mapeamento de orientações; b) FDO da região analisada. Direção de laminação paralela à direção vertical.

Figura 75 - Análise através de EBSD da amostra caster com 67\% de redução e recristalizada a $400^{\circ} \mathrm{C}$ por 1 hora: a) Mapeamento de orientações; b) FDO da região analisada. Direção de laminação paralela à direção vertical.

Figura 76 - Variação da microdureza Vickers (carga 50gf) em função da redução em área durante laminação a frio de duas condições: caster e caster com prévia homogeneização. A designação caster se refere à amostra no estado bruto de fundição.

Figura 77 - Image Quality de uma amostra retirada da chapa que sofreu tratamento térmico de $550^{\circ} \mathrm{C} / 24 \mathrm{~h}$. Região da superfície da amostra. Direção de laminação paralela à direção vertical.

Figura 78 - Análise de EBSD ao longo da espessura para determinar CSL da amostra caster bruta de fundição: a) superfície da amostra; b) na região $1 / 4$ de espessura; c) na região $1 / 2$ de espessura. Direção de laminação paralela à direção vertical.

Figura 79 - Variação da microdureza Vickers em função da temperatura de duas condições: caster e caster com prévia homogeneização. A designação caster se refere à amostra no estado bruto de fundição. 
Figura 80 - Microestrutura da amostra caster recozida a $300^{\circ} \mathrm{C} / 1 \mathrm{~h}$ (após $91 \%$ de redução, sem tratamento térmico prévio de homogeneização), microscopia eletrônica de transmissão. Amostra afinada eletroliticamente com solução contendo ácido perclórico

Figura 81 - Microestrutura da amostra caster recozida a $500^{\circ} \mathrm{C} / 1 \mathrm{~h}$, após $91 \%$ de redução. Microscopia óptica com luz polarizada. Amostra anodizada com solução contendo ácido fluobórico. Direção de laminação paralela à direção horizontal. a) laminada sem tratamento térmico prévio de homogeneização; b) laminada com tratamento térmico prévio de

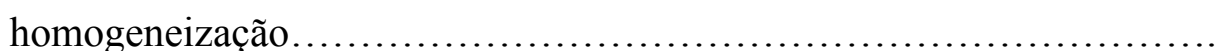

Figura 82 - Figura de pólo 111 da amostra caster com 91\% de redução, laminada sem tratamento térmico prévio de homogeneização.

Figura 83 - Figura de pólo 111 da amostra caster com 91\% de redução, laminada com tratamento térmico prévio de homogeneização.

Figura 84 - ODF da amostra caster sem prévia homogeneização após 91\% de redução

Figura 85 - Mapeamento de orientação e FP's obtidas por EBSD da amostra caster sem prévia homogeneização após $91 \%$ de redução e tratamento térmico de $500^{\circ} \mathrm{C} / 1 \mathrm{~h}$. Direção de laminação paralela à direção vertical...

Figura 86 - Mapeamento de orientação, FP's e FDO obtidos por EBSD da amostra caster com prévia homogeneização após 91\% de redução e tratamento térmico de $500^{\circ} \mathrm{C} / 1 \mathrm{~h}$. Direção de laminação paralela à direção vertical

Figura 87 - Gráfico do parâmetro $\rho_{0, \mathrm{~N}}$ calculado em função do número de orientações medidas, dados da amostra caster superfície 
Figura 88 - FDO (EBSD) da amostra caster superfície a partir de 17000 pontos....

Figura 89 - FDO (EBSD) da amostra caster superfície a partir de 50500 pontos....

Figura 90 - Difratograma (utilizando-se tubo de cobre) do filtro de PTFE com resíduo extraído da amostra caster, pela dissolução química em solução de iodo e metanol.

Figura 91 - Difratograma (utilizando-se tubo de cobre) do resíduo extraído da amostra caster, pelo método de dissolução química em solução de iodo e metanol.

Figura 92 - Difratograma (utilizando-se tubo de cobre) do resíduo extraído de amostra homogeneizada a $500^{\circ} \mathrm{C}$ por $12 \mathrm{~h}$. Dissolução química por fenol. Varredura lenta com tempo de exposição de 10 segundos.

Figura 93 - Difratograma (utilizando-se tubo de cobre) do resíduo extraído de amostra homogeneizada a $550^{\circ} \mathrm{C}$ por $120 \mathrm{~h}$. Dissolução química por fenol. Varredura lenta com tempo de exposição de 10 segundos.

Figura 94 - Difratograma (utilizando-se tubo de cobre) do resíduo extraído da amostra caster pela dissolução eletrolítica com solução contendo ácido perclórico.

Figura 95 - Difratograma (utilizando-se tubo de cobre) do resíduo extraído da amostra caster pela dissolução eletrolítica com solução contendo ácido perclórico. Varredura lenta com tempo de exposição de 10 segundos......

Figura 96 - Difratograma (utilizando-se tubo de cobre) do resíduo extraído da amostra caster homogeneizada a $500^{\circ} \mathrm{C}$ por 12 horas pela dissolução eletrolítica com solução contendo ácido perclórico. Varredura lenta com tempo de exposição de 10 segundos 
Figura 97 - Microestrutura da amostra caster homogeneizada a $500^{\circ} \mathrm{C}$ por 12 horas, microscopia óptica, ataque de solução $0,5 \% \mathrm{HF}$ e em seguida solução aquosa de $\mathrm{KMnO}_{4} \cdot \mathrm{Na}_{2} \mathrm{CO}_{3}$

Figura 98 - Microestrutura da amostra caster homogeneizada a $500^{\circ} \mathrm{C}$ por 12 horas, microscopia eletrônica de varredura, elétrons retroespalhados.......

Figura 99 - Microestrutura do caster após homogeneização de $500^{\circ} \mathrm{C}$ por 12 horas, microscopia eletrônica de transmissão. Amostra afinada eletroliticamente com solução contendo ácido perclórico.

Figura 100 - a) Precipitado presente na amostra caster após homogeneização de $500^{\circ} \mathrm{C} / 12 \mathrm{~h}$, microscopia eletrônica de transmissão; b) Difração de elétrons da fase A16Mn, precipitado preto mostrada em a). A direção do feixe de elétrons é indicada na micrografia. Amostra afinada eletroliticamente com solução contendo ácido perclórico

Figura 101- Amostra caster, homogeneizada a $500^{\circ} \mathrm{C} / 12 \mathrm{~h}$ e parcialmente dissolvida em fenol, microscopia eletrônica de varredura, elétrons retroespalhados.

Figura 102 - Pó obtido pela dissolução química por fenol da amostra caster homogeneizada $500^{\circ} \mathrm{C} / 12 \mathrm{~h}$, microscopia eletrônica de varredura, elétrons secundários.

Figura 103 - Amostra caster homogeneizada a $550^{\circ} \mathrm{C}$ por $120 \mathrm{~h}$ e parcialmente dissolvida em fenol. Microscopia eletrônica de varredura, imagens de elétrons retroespalhados.

Figura 104 - Fração volumétrica dos precipitados de amostras homogeneizadas a $550^{\circ} \mathrm{C}$ por diversos tempos

Figura 105 - Microestrutura da amostra homogeneizada a $550^{\circ} \mathrm{C}$ por $2 \mathrm{~h}$, 
microscopia de transmissão. Amostra afinada eletroliticamente com solução contendo ácido perclórico.

Figura 106 - a) Precipitado da amostra homogeneizada a $550^{\circ} \mathrm{C} / 120 \mathrm{~h}$; b) difração de elétrons do precipitado indexada como fase $\alpha$ na direção [011] plano mais próximo é da família $\left\{\begin{array}{llll}0 & 2 & 2\end{array}\right\}$ e o segundo mais próximo é $\{2$ $22\}$. Amostra afinada eletroliticamente com solução contendo ácido perclórico.

Figura 107 - Evolução da resistividade elétrica da liga 3003 durante tratamento térmico a $550^{\circ} \mathrm{C}$ 


\section{LISTA DE TABELAS}

Tabela 1 - Solubilidade (em \% em peso) dos principais elementos de liga do alumínio, nos sistemas binários

Tabela 2 - Principais propriedades da liga 3003 no estado recozido e do alumínio.

Tabela 3 - Informações sobre as fases encontradas na liga 3003

Tabela 4 - Coeficientes de difusão calculadas, em $\mathrm{cm}^{2} / \mathrm{s}$, dos elementos que compõe a liga 3003 em algumas temperaturas.

Tabela 5 - Comparação de profundidade de penetração.

Tabela 6. Composição química (em \% em peso) da chapa laminada a quente e da chapa produzida por fundição contínua de chapas (“Caster”) em três posições diferentes: superfície, $1 / 4$ da espessura abaixo da superfície e no centro da chapa.

Tabela 7. Deformações reais e reduções em área obtidas para as duas placas laminadas.

Tabela 8. Valores de microdureza Vickers (300g) da amostra laminada a quente e da amostra caster ao longo da espessura: superfície, 1/4 da espessura abaixo da superfície e no centro da chapa.

Tabela 9 - Medida de fração volumétrica de precipitados ao longo da espessura das amostras provenientes do processo roll caster e da laminação a quente.

Tabela 10 - Comparação entre os métodos de extração de precipitados. 
Tabela 11 - Fração volumétrica de precipitados para amostra homogeneizada a $500^{\circ} \mathrm{C}$ por 12 horas e no estado bruto de fundição ( $1 / 2$ espessura).............

Tabela 12 - Análise feita por EDS do pó apresentado na Figura 102 


\section{LISTA DE SÍMBOLOS}

\begin{tabular}{|c|c|}
\hline $\mathrm{C}_{\mathrm{S}}$ & concentração de soluto no sólido \\
\hline $\mathrm{C}_{\mathrm{L}}$ & concentração de soluto no líquido \\
\hline CBA & Companhia Brasileira de Alumínio/SP \\
\hline $\mathrm{CCC}$ & cúbico de corpo centrado \\
\hline $\mathrm{CFC}$ & cúbico de face centrada \\
\hline $\mathrm{d}$ & diâmetro de grão \\
\hline $\mathrm{d}$ & distância interplanar \\
\hline$d_{c}$ & diâmetro de grãos com orientação do tipo cubo \\
\hline$d_{r}$ & diâmetro de grãos orientados ao acaso \\
\hline DL & direção de laminação \\
\hline $\mathrm{DN}$ & direção normal à superfície da chapa \\
\hline DT & direção transversal à direção de laminação \\
\hline EBSD & difração de elétrons retroespalhados (electron backscatter diffraction) \\
\hline EDE & energia de defeito de empilhamento \\
\hline EDS & espectroscopia de energia dispersiva \\
\hline $\mathrm{f}$ & fração volumétrica dos precipitados \\
\hline $\mathrm{f}(\mathrm{g})$ & freqüência de ocorrência de determinadas orientações \\
\hline $\mathrm{F}_{\mathrm{p}}$ & força que um precipitado esférico exerce num contorno \\
\hline $\mathrm{F}_{\mathrm{V}}$ & fração volumétrica de partículas \\
\hline $\mathrm{F}_{0}$ & função distribuição de orientações obtida por difração de raios $\mathrm{X}$ \\
\hline $\mathrm{F}_{\mathrm{N}}$ & função distribuição de orientações obtida por EBSD \\
\hline FDO & função distribuição de orientação \\
\hline FP & Figura de pólo \\
\hline I & corrente de excitação \\
\hline $\mathrm{k}$ & constante \\
\hline $\mathrm{k}$ & coeficiente de partição \\
\hline
\end{tabular}




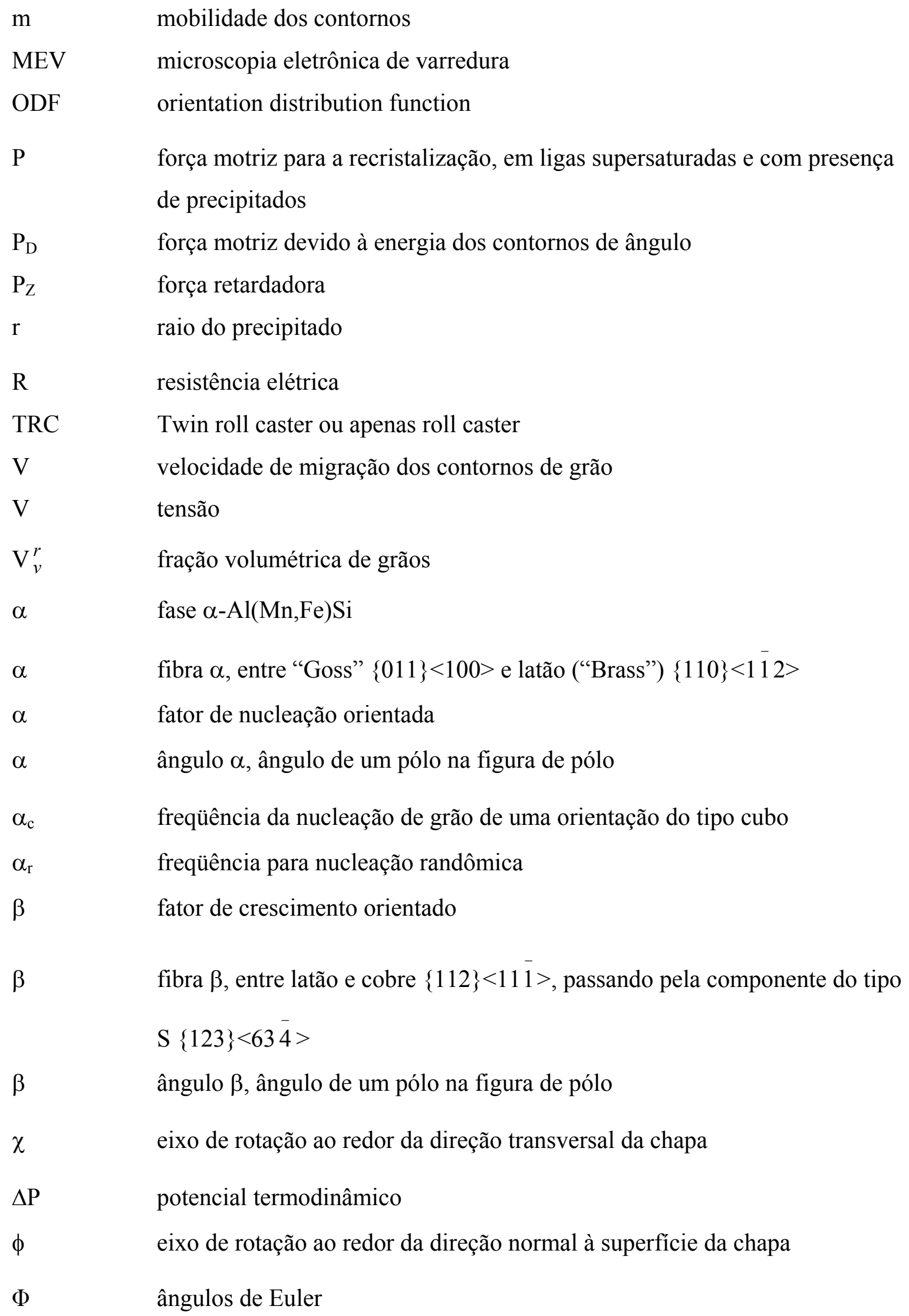


energia de superfície do contorno de grão

energias dos contornos de subgrãos

$\gamma_{\mathrm{GB}}$

energias dos contornos de alto ângulo

$\varphi_{1} \quad$ ângulos de Euler

$\varphi_{2} \quad$ ângulos de Euler

$\lambda \quad$ comprimento de onda

$\theta \quad$ ângulo da lei de Bragg

$\rho_{0, \mathrm{~N}} \quad$ parâmetro estatístico, para a comparação entre as FDO obtidas por difração de raios $\mathrm{X}$ e por EBSD

$\rho \quad$ resistividade elétrica

$\rho(\mathrm{T}) \quad$ resistividade elétrica devido a vibrações térmicas

$\rho(C) \quad$ resistividade elétrica devido aos átomos de impureza

$\rho(\mathrm{L}) \quad$ resistividade elétrica devido à presença de lacunas

$\rho(d) \quad$ resistividade elétrica devido à presença de discordâncias

$\rho$ (b) resistividade elétrica devido à presença de defeitos bidimensionais tensão de escoamento resultante do endurecimento por refino de grão

$\sigma$ condutividade elétrica

$\sigma_{0} \quad$ tensão de escoamento inicial

$\psi$ desorientação de contornos de grão 


\section{RESUMO}

A principal motivação para o desenvolvimento do presente projeto de doutorado foi comparar as microestruturas e texturas resultantes da liga de alumínio 3003 obtida por lingotamento contínuo e semicontínuo. O processo "roll caster" (lingotamento contínuo em cilindros) tem sido crescentemente utilizado na indústria de laminação de alumínio. Produtos que antes sofriam altos graus de deformação durante seu processamento são hoje obtidos nas dimensões próximas da espessura final. Com o intuito de entender este processo relativamente novo, as microestruturas $\mathrm{e}$ as texturas (macrotextura e microtextura), ao longo da espessura, das chapas produzidas por lingotamento contínuo e por lingotamento semicontínuo (placas fundidas com $250 \mathrm{~mm}$ de espessura, seguido de homogeneização e laminação a quente) foram analisadas. Foi possível constatar que os materiais provenientes dos dois processos diferem bastante e que ao longo da espessura também há grandes diferenças. Foi possível observar que durante o processamento "roll caster" há considerável deformação plástica, com a formação de células de discordâncias e subgrãos. Foi possível observar, também, que a microestrutura, a morfologia e o tamanho de grão, da amostra "caster" bruta de fundição são mais homogêneos que na amostra laminada a quente. As duas chapas, a laminada a quente e a obtida por lingotamento contínuo, exibem forte gradiente de textura ao longo da espessura. A textura predominante nos dois processos, ao longo da espessura, é a do tipo latão $\{011\}<211>$.

A evolução da textura do material proveniente do processo "roll caster" também foi caracterizada após laminação e posterior recristalização, revelando a presença de componentes típicas de laminação e de recristalização de alumínio. Após laminação a frio com redução de $91 \%$ e posterior tratamento térmico de $400^{\circ} \mathrm{C}$ por $1 \mathrm{~h}$, a chapa proveniente do processo "caster" apresentou uma textura de recristalização caracterizada pela presença da componente cubo (recristalização) somada à parcela de textura de deformação. No caso do alumínio e suas ligas, sabe-se que esta textura proporciona os melhores resultados para minimizar o efeito de orelhamento durante a estampagem.

Outro ponto relevante do trabalho foi o aperfeiçoamento da técnica de extração de precipitados para a liga 3003, uma vez que, a extração de precipitados em ligas de alumínio 
é especialmente problemática, pois a maioria das partículas presentes dissolve-se até mais facilmente que a matriz de alumínio. Algumas técnicas foram testadas:

1. dissolução química em solução de iodo em metanol;

2. dissolução eletrolítica em solução de ácido benzóico e hidroxiquinolina em clorofórmio e metanol;

3. dissolução eletrolítica em solução de ácido perclórico, butil glicol, álcool etílico e água;

4. dissolução química em solução de fenol.

A técnica que apresentou melhores resultados foi a dissolução química com fenol, onde foi possível separar os precipitados da matriz alumínio. Com o auxílio desta técnica foi possível analisar as transformações de fase do composto intermetálico $\mathrm{Al}_{6} \mathrm{Mn}$ durante tratamentos térmicos. Obtiveram-se dados da completa transformação da fase $\mathrm{Al}_{6} \mathrm{Mn}$ em $\alpha$ AlMnSi, também conhecida na literatura como, transformação $6 \rightarrow \alpha$.

A precipitação e os precipitados desempenham um papel importante na cinética de recristalização e no tamanho de grão final. Para se entender este comportamento, comparou-se uma chapa que sofreu tratamento térmico antes da laminação com outra chapa que foi laminada no estado bruto de fundição. Os resultados revelaram que a recristalização foi retardada na amostra, inicialmente, bruta de fundição. A precipitação ocorreu simultaneamente com a recristalização, com isso, os dispersóides precipitaram preferencialmente na microestrutura deformada, em subcontornos ou nas discordâncias isoladas, levando a um considerável atraso no rearranjo das discordâncias e na nucleação da recristalização. 


\begin{abstract}
The main reason for the development of this $\mathrm{PhD}$ Thesis was to compare the microstructures and textures of the 3003 aluminum alloy produced from continuous and semi-continuous casting processes. The roll caster process (continuous casting) has been increasingly used in the aluminum industry. Products usually obtained by means of heavy rolling operations in the past are nowadays obtained with dimensions close to the final ones using the roll caster technology. To understand this new process, microstructures and textures (macrotexture and microtexture) along the thickness of the sheet produced by continuos casting and semi-continuous casting (plates with $250 \mathrm{~mm}$ thickness, followed by homogenization and hot rolling) have been investigated. It was possible to verify that materials coming from these two processes did differ each other a lot mainly across the thickness. During roll casting the plastic deformation was large enough to promote the formation of dislocation cells and subgrains. It was also possible to notice that the microstructure, morphology, and grain size from as-cast sample are more homogenous than the ones found in hot rolled samples. Both the sheets obtained by hot rolling and continuous casting have shown a strong texture gradient across the thickness. The predominant texture in both processes is the Brass component $\{011\}<211>$.

The texture evolution from sheets obtained by roll casting was also determined after rolling and subsequent recrystallization. It shows the presence of typical components of rolling and recrystallization of aluminum. After 91\% cold rolling and subsequent recrystallization at $400^{\circ} \mathrm{C}$ for $1 \mathrm{~h}$, the cube component (recrystallization texture) and the deformation texture were observed. It is well known that this texture minimizes earing effects during deep drawing of aluminum products.

Another relevant point in this work was the development of the technique for the extraction of precipitates for the aluminum 3003 alloy. The extraction of precipitates extraction is particularly problematic in aluminum because most of the particles tend to dissolve more readily than the aluminum matrix. Some of the techniques performed are the following:
\end{abstract}

1. chemical dissolution with iodine in methanol solution; 
2. electrolytic dissolution with benzoic acid and hydroxyquinoline in chloroform and methanol;

3. electrolytic dissolution with perchloric acid, butyl-glycol and ethanol;

4. chemical dissolution with phenol solution.

Chemical dissolution with the phenol solution was the technique that provided the best results. It was possible to separate precipitates from the aluminum matrix. With this extraction technique it was possible to analyze phase transformations of the intermetallic compound $\mathrm{Al}_{6} \mathrm{Mn}$ during heat treating of this alloy. The phase transformation of the $\mathrm{Al}_{6} \mathrm{Mn}$ compound into $\alpha$-AlMnSi, also known as 6-to- $\alpha$ transformation, could be followed in detail by means of this technique.

Precipitation plays an important role in the recrystallization kinetics and final grain size. Therefore, to understand this behavior, the roll cast aluminum alloy was cold rolled from two distinct starting conditions: as-cast and heat-treated (homogeneized) conditions. It was shown that recrystallization was delayed in the sheet rolled from the as-cast condition. Precipitation has occurred simultaneously with recrystallization, in such a manner that dispersoids did precipitate in the deformed microstructure, preferentially, at subgrain boundaries or at free dislocations. As a result, the rearrangement of the dislocations and further recrystallization nucleation has been significantly retarded. 


\section{Introdução}

A maior parte da produção de alumínio consiste de produtos planos laminados e extrudados, com forte predominância dos primeiros [Sanders, 2001]. O entendimento de fenômenos como encruamento, recuperação, recristalização e crescimento de grão são essenciais não só para se conformar corretamente esses produtos, mas também para controlar suas microestruturas, texturas e relações de orientação entre as fases e, dessa maneira, otimizar suas propriedades e desempenho. Os fenômenos mencionados acima, por sua vez, dependem fortemente da composição da liga e da quantidade, tamanho, morfologia e distribuição das fases presentes em sua microestrutura. Um dos principais objetivos do presente trabalho é comparar a microestrutura e a textura cristalográfica de duas chapas da liga Al-Mn-Fe-Si (3003) de espessuras semelhantes, mas que foram obtidas por processos diferentes (lingotamento contínuo e lingotamento semicontínuo). Uma das chapas tem $6 \mathrm{~mm}$ de espessura e foi produzida (em 1975) por lingotamento semicontínuo de placas com $250 \mathrm{~mm}$ de espessura, seguido de homogeneização e laminação a quente. A outra chapa tem 7,4 mm de espessura, foi produzida (em 2002) por fundição contínua de chapas ("roll caster") e encontra-se no estado bruto de fundição.

A liga 3003 contém essencialmente alumínio, manganês (1,0-1,5), ferro (máx. 0,7) e silício (máx. 0,6). A Tabela 1 apresenta resultados de solubilidade dos principais solutos nos sistemas binários presentes na liga. A presença do ferro e do silício reduz ainda mais a solubilidade do manganês no sistema quaternário [Hausch et al, 1978]. A análise dos dados da Tabela 1 sugere que após o processamento termomecânico, praticamente todo $\mathrm{Fe}$, Si e grande parte do $\mathrm{Mn}$ da liga devem estar concentrados nos precipitados.

As principais fases que ocorrem na liga 3003 são a fase $\mathrm{Al}_{6}(\mathrm{Mn}, \mathrm{Fe})$ e a fase $\alpha$ $\mathrm{Al}_{12}(\mathrm{Fe}, \mathrm{Mn})_{3} \mathrm{Si}$, além de partículas (cristais) de silício. Enquanto as partículas de $\mathrm{Al}_{6}(\mathrm{Mn}, \mathrm{Fe})$ e de $\mathrm{Si}$ são maiores e originárias da solidificação (primárias), as partículas de $\alpha-\mathrm{Al}_{12}(\mathrm{Fe}, \mathrm{Mn})_{3} \mathrm{Si}$ são em geral mais finas e podem tanto ser formada na 
solidificação, como ser produto da transformação do $\mathrm{Al}_{6}(\mathrm{Mn}, \mathrm{Fe})$ em $\alpha-\mathrm{Al}_{12}(\mathrm{Fe}, \mathrm{Mn})_{3} \mathrm{Si}$, que ocorre durante o tratamento térmico de homogeneização. $O$ estudo desta transformação ainda está bastante incompleto na literatura e seu estudo também é um dos objetivos do presente trabalho. A precipitação e os precipitados desempenham um papel importante na cinética de recristalização durante o processamento termomecânico e no tamanho de grão final [Pimenta et al, 1986].

Tabela 1: Solubilidade (em \% em peso) dos principais elementos de liga do alumínio, nos sistemas binários [Davis, 1993].

\begin{tabular}{|c|c|c|c|c|}
\hline $\begin{array}{c}\text { Elemento de } \\
\text { liga }\end{array}$ & $\begin{array}{c}\text { Solubilidade } \\
\text { máxima no } \\
\text { estado sólido }\end{array}$ & $\begin{array}{c}\text { Solubilidade em } \\
\text { temperatura mais } \\
\text { baixa }\end{array}$ & $\begin{array}{c}\text { Diferença de raio } \\
\text { atômico (\%) }\end{array}$ & $\begin{array}{c}\text { Estrutura } \\
\text { cristalina }\end{array}$ \\
\hline $\mathbf{S i}$ & $1,65\left(577^{\circ} \mathrm{C}\right)$ & $0,05\left(250^{\circ} \mathrm{C}\right)$ & $-6,3$ & $\mathrm{Cúbica;} \mathrm{A4}$ \\
\hline $\mathbf{F e}$ & $0,052\left(655^{\circ} \mathrm{C}\right)$ & $0,001\left(400^{\circ} \mathrm{C}\right)$ & $-11,2$ & $\mathrm{CCC} / \mathrm{CFC}$ \\
\hline $\mathbf{C u}$ & $5,65\left(548^{\circ} \mathrm{C}\right)$ & $0,2\left(200^{\circ} \mathrm{C}\right)$ & $-11,2$ & $\mathrm{CFC}$ \\
\hline $\mathbf{M n}$ & $1,82\left(659^{\circ} \mathrm{C}\right)$ & $0,36\left(500^{\circ} \mathrm{C}\right)$ & $-8,4$ & $\mathrm{Cúbica}$; 12 \\
\hline $\mathbf{Z n}$ & $82,8\left(382^{\circ} \mathrm{C}\right)$ & $4,4\left(100^{\circ} \mathrm{C}\right)$ & $-4,2$ & $\mathrm{HC}$ \\
\hline
\end{tabular}

Os objetivos do presente trabalho encontram-se listados abaixo:

- Caracterização da textura das chapas produzidas por lingotamento contínuo ("roll caster") e por lingotamento semi-contínuo ao longo da espessura da liga de alumínio 3003;

- Comparação das microestruturas e texturas resultantes dos materiais obtidos por lingotamento contínuo e semicontínuo;

- Caracterização da evolução da textura nas diversas etapas de processamento termomecânico da chapa produzida por lingotamento contínuo;

- Aperfeiçoamento da técnica de extração de precipitados para a liga 3003;

- Estudo das transformações de fase do composto intermetálico $\mathrm{Al}_{6} \mathrm{Mn}$ durante tratamento térmico. 


\section{REVISÃO DA LITERATURA}

A presente revisão bibliográfica é composta das seguintes partes: uma introdução geral sobre a indústria de alumínio no Brasil (item 2.1), onde são descritas, brevemente, a história do alumínio e também suas principais aplicações. A seguir são apresentadas as propriedades e aplicações da liga 3003 que foi utilizada no presente trabalho (item 2.2). No item seguinte (item 2.3) foi dada ênfase em apresentar a liga Al-Mn, com informações históricas, sua composição, sua aplicação, seu processo de solidificação e sobre as transformações de fase que ocorrem durante o tratamento térmico de homogeneização. O processo "roll caster", que também está sendo avaliado no presente trabalho, é um processo relativamente novo e maiores informações são encontradas no item 2.4. Como um dos objetivos do trabalho é o entendimento de fenômenos como encruamento, recuperação, recristalização, precipitação durante a recristalização e crescimento de grão, da liga 3003, estes fenômenos são descritos no item 2.5. A avaliação da textura foi uma análise bastante utilizada e, portanto, os métodos de análise de textura são descritos no item 2.6. Para a identificação de precipitados foi utilizado, dentre outros, o método de difração de elétrons, com isso, aproveitou-se para fazer um breve resumo de como é feita esta análise (item 2.7).

\subsection{A indústria de alumínio no Brasil}

Em 1809, Humphrey Davy fundiu ferro na presença de alumina, obtendo uma liga de ferro e um novo metal que batizou de 'alumium', mais tarde chamado 'aluminium'. Em 1825, o físico dinamarquês Hans Christian Oersted isolou o alumínio pela redução do cloreto de alumínio por potássio. A indústria do alumínio nasceu no fim do século XIX nos EUA e na Europa, resultando das descobertas de dois inventores Hall e Heroult (as duas descobertas foram simultâneas e independentes em 1886) que puderam dispor de alumina produzida pelo processo Bayer e de geradores elétricos de corrente contínua que tinham sido desenvolvidos também alguns anos antes [Machado, 1986]. 
Desde 1913, uma pequena fábrica de nome desconhecido, na cidade de São Paulo, já produzia utensílios de alumínio. Em 1945, por iniciativa de Américo Giannetti, o país fabrica as primeiras toneladas de alumínio primário. Em 1983, passa de grande importador a um dos principais exportadores mundiais, graças aos grandes e contínuos investimentos das empresas do setor. Três anos depois, o Brasil torna-se o quinto produtor mundial de alumínio primário. A produção de alumínio primário nacional, hoje de 1,2 milhão de toneladas, é dez vezes maior do que a de 1970, ano em que o Brasil ocupava o posto de $24^{\circ}$ produtor mundial. Atualmente é o sexto, atrás apenas dos Estados Unidos, Rússia, China, Canadá e Austrália. O consumo por habitante passou de $1,1 \mathrm{~kg} / \mathrm{hab} /$ ano para $4 \mathrm{~kg} / \mathrm{hab} /$ ano no mesmo período [Vieira, 2000].

A descoberta em 1967 de grandes reservas do minério do alumínio no Pará, na área do Rio Trombetas, teve resultados muito importantes para o Brasil. Hoje o país é o terceiro maior produtor de bauxita e quarto de alumina [Vieira, 2000].

A importância da indústria do alumínio para o país é comprovada pela significativa participação no PIB (1\% no PIB total em 1999) e pela participação das exportações, que alcançaram no ano de 2000 cerca de 3,5\% do total [Vieira, 2000].

As principais características do alumínio são: versatilidade e durabilidade, impermeabilidade e opacidade, facilidade de conformação, alta condutibilidade térmica e elétrica, ótima resistência à corrosão, razoável resistência mecânica, baixo peso específico, excelente aspecto estético, reciclabilidade.

As principais aplicações do alumínio são:

- Indústria de transporte: automóveis, caminhões, ônibus, autopeças vagões, trailers, radiadores, rodas, carrocerias e implementos agrícolas.

- Indústria de eletricidade: cabos condutores, barramentos, eletrodutos, capacitores, lâmpadas e luminárias. 
- Máquinas e equipamentos: Peças fundidas para máquinas industriais de mineração e de agricultura, componentes, tais como, chapas, tubos, perfis, chapas litográficas e peças usinadas.

- Embalagens: para medicamentos, bebidas e produtos alimentícios como, bisnagas, tubos rígidos, tampas, cápsulas, latas, bandejas, recipientes térmicos e papel alumínio.

- Bens de consumo: eletrodomésticos, eletroeletrônicos, utensílios domésticos, máquinas de escritório, móveis, barcos, brinquedos e artigos esportivos.

- Construção civil: estruturas, portas, fachadas, box de banheiro, forros, divisórias, persianas, telhas, toldos, calhas, revestimentos internos, revestimentos externos, revestimentos de fachadas e silos.

- Diversos: Tubos para irrigação, explosivos, combustível para foguete, esculturas, tintas metálicas, desoxidante na indústria siderúrgica e redutor na fabricação de ferro-ligas, etc.

\subsection{Propriedades e aplicações da liga 3003}

Dentre as ligas do sistema Al-Mn, também conhecidas como ligas da série 3XXX, uma das mais utilizadas é a 3003 [Mondolfo, 1977]. A liga 3003 é uma das ligas de alumínio mais antigas e até hoje é amplamente utilizada. Ela preenche em parte o vazio existente entre o alumínio comercialmente puro e as ligas de alumínio de alta resistência (endurecíveis por precipitação coerente). A adição de manganês proporciona aumento de resistência mecânica, causando uma redução ligeira na ductilidade. A sua resistência à corrosão também é melhor que a das ligas Al-Fe-Si (alumínio comercialmente puro). Apresenta boas conformabilidade e soldabilidade. É comumente utilizada na forma de chapa, folha e tubos. Dentre suas numerosas aplicações, pode-se 
destacar trocadores de calor em indústrias, radiadores de veículos e utensílios de cozinha.

Tabela 2. Principais propriedades da liga 3003 no estado recozido e do alumínio [Davis, 1993].

\begin{tabular}{|l|l|}
\hline Número atômico do Al & 13 \\
\hline Peso atômico do $\mathrm{Al}$ & 26,98 \\
\hline Estrutura cristalina do $\mathrm{Al}$ & $\mathrm{CFC}$ \\
\hline Parâmetro de rede do $\mathrm{Al}$ & $4,04 \AA$ \\
\hline Ponto de fusão do $\mathrm{Al}$ & $660^{\circ} \mathrm{C}$ \\
\hline Densidade a $20^{\circ} \mathrm{C}$ da liga & $2,73 \mathrm{~g} / \mathrm{cm}^{3}$ \\
\hline Condutividade elétrica a $20^{\circ} \mathrm{C}$ da liga & $50 \% \mathrm{IACS}$ \\
\hline Resistividade elétrica a $20^{\circ} \mathrm{C}$ da liga & $34 \mathrm{n} \Omega . \mathrm{m}$ \\
\hline Calor específico a $20^{\circ} \mathrm{C}$ da liga & $893 \mathrm{~J} / \mathrm{Kg} . \mathrm{K}$ \\
\hline Condutividade térmica a $20^{\circ} \mathrm{C}$ da liga & $193 \mathrm{~W} / \mathrm{m} . \mathrm{K}$ \\
\hline Limite de resistência à tração da liga & $110 \mathrm{MPa}$ \\
\hline Limite de escoamento da liga & $42 \mathrm{MPa}$ \\
\hline Alongamento da liga & $30-40 \%$ \\
\hline Módulo de elasticidade da liga & $70 \mathrm{GPa}$ (tração) \\
\hline Resistência à fadiga da liga & $25 \mathrm{GPa}$ (cisalhamento) \\
\hline Dureza da liga & $48 \mathrm{MPa}$ \\
\hline
\end{tabular}

\subsection{Ligas Al-Mn}

O uso comercial de Mn como adição nas ligas de alumínio remonta ao início do século, embora a produção de ligas Al-Mn em laboratório tivesse ocorrido cinqüenta anos antes. Hoje o Mn, apesar de ser utilizado em pequenos teores é um importante elemento de liga na indústria do alumínio [Kolososki et al, 1998].

A utilização do Mn como elemento de liga do alumínio tem sido mais difundida na Europa do que nos Estados Unidos, onde é substituído pelo Cr em certas ligas. Tal comportamento, contudo, pode ser atribuído mais a uma certa tradição do que razões puramente técnico - econômicas. De fato, uma vez que o Mn é um metal abundante e mais barato, seu emprego contribui para a obtenção de ligas de Al mais econômicas e, portanto, mais competitivas [Kolososki et al, 1998]. 
Os primeiros estudos sobre a utilização de ligas Al-Mn são citados em 1902. O uso comercial destas ligas teve início em 1910 [Mondolfo, 1977]. Inicialmente, o Mn era usado tanto em ligas conformadas como para fundição. Sua utilidade neste último caso era aumentar a fluidez do metal líquido e contrabalançar o efeito do Fe (pequena quantidade de impurezas, especialmente $\mathrm{Fe}$, exerce forte influência em diminuir a solubilidade do $\mathrm{Mn}$ ) presente como impureza [Kolososki et al, 1998]. Uma peculiaridade de ligas de Al, que não é encontrada em ligas de outros metais, é o limite de solubilidade da maioria de elementos de liga na matriz. Enquanto em aços, pequenas adições da maioria dos elementos se dissolvem e não afetam apreciavelmente a estrutura cristalina básica, para $\mathrm{Al}$ mesmo pequenas adições da maioria de elementos criam uma ou mais novas fases [Mondolfo, 1977].

Embora a composição da liga e das fases individuais demonstre que esta é uma liga de 4 componentes, nota-se que todas as fases presentes são comuns ao sistema Al$\mathrm{Mn}-\mathrm{Si}$. Ou seja, a microestrutura desta liga tem sua origem no sistema Al-Mn-Fe-Si, mas pode ser descrita pelo diagrama de fase Al-Mn-Si [Sperry, 1955].

A faixa de composição das ligas comerciais Al-Mn é muito limitada: a composição do manganês varia de 1 a $1,7 \%$; cobre varia de 0,05 a $0,2 \%$, usualmente adicionado para reduzir a corrosão por pitting; ferro e silício, cada um pode ser tolerado até $0,6-0,7 \%$, aumentam a resistência mecânica sem muita perda da resistência à corrosão. Ligas brutas de fundição com 5 a $6 \%$ de Mn foram usadas no passado, mas atualmente não são mais utilizadas. No sistema Al-Mn, a solubilidade máxima do Mn é $1,82 \%$ a $658^{\circ} \mathrm{C}$ e diminui para $0,2 \%$ a $427^{\circ} \mathrm{C}$ [Mondolfo, 1976]. A pequena quantidade de Mn em ligas Al-Mn é imposta pela presença de Fe como impureza que reduz a solubilidade do Mn e para evitar que se formem grandes partículas primárias de $\mathrm{Al}_{6} \mathrm{Mn}$ que tem um efeito desastroso na ductilidade [Polmear, 1989].

A liga conhecida como 3003 consiste, basicamente, da adição de Mn ao alumínio comercialmente puro [Davis, 1993]. As fases que podem ser encontradas na liga bruta de fundição são solução sólida de $\mathrm{Mn}$ em Al, $\mathrm{Al}_{6}(\mathrm{Mn}, \mathrm{Fe}), \alpha-\mathrm{Al}(\mathrm{Mn}, \mathrm{Fe}) \mathrm{Si}$ e Si [Mondolfo, 1977; Sperry, 1955]. A fase $\mathrm{Al}_{6}(\mathrm{Mn}, \mathrm{Fe})$ nada mais é que $\mathrm{Al}_{6} \mathrm{Mn}$ e a fase $\alpha-\mathrm{Al}(\mathrm{Mn}, \mathrm{Fe}) \mathrm{Si}$ 
é $\alpha-\mathrm{AlMnSi}$, onde alguns dos átomos de $\mathrm{Mn}$ podem ser substituídos por Fe sem que ocorram alterações significativas nestas fases.

Tabela 3 - Informações sobre as fases encontradas na liga 3003 [Hansen et al, 1995].

\begin{tabular}{|c|c|c|c|c|}
\hline & $\begin{array}{c}\text { Estrutura } \\
\text { cristalina }\end{array}$ & $\begin{array}{c}\text { Parâmetro de } \\
\text { rede a }(\mathrm{nm})\end{array}$ & $\begin{array}{c}\text { Parâmetro de } \\
\text { rede b }(\mathrm{nm})\end{array}$ & $\begin{array}{c}\text { Parâmetro de } \\
\text { rede c (nm) }\end{array}$ \\
\hline $\mathrm{Al}_{6} \mathrm{Mn}$ & Ortorrômbica & 0,646 & 0,744 & 0,879 \\
\hline$\alpha-\mathrm{Al}_{12}(\mathrm{Mn}, \mathrm{Fe})_{3} \mathrm{Si}$ & CCC & 1,268 & - & - \\
\hline $\mathrm{Si}$ & Cúbica & 0,543 & - & - \\
\hline
\end{tabular}

\subsubsection{Processo de solidificação}

Sperry [Sperry, 1955] verificou que em amostras resfriadas a $0,5^{\circ} \mathrm{C} / \mathrm{min}$ ocorrem três transformações mostradas no diagrama Al-Mn-Si (Figura 1). Primeiro há o eutético binário resultante da reação

$$
\text { Líquido } \rightarrow \mathrm{Al}+\mathrm{Al}_{6} \mathrm{Mn} \text { (linha ab da Figura 1). }
$$

Há também o peritético, resultante da reação

$$
\text { Líquido }+\mathrm{Al}_{6} \mathrm{Mn} \rightarrow \mathrm{Al}+\alpha-\mathrm{AlMnSi} \text { (ponto b da Figura 1). }
$$

Finalmente, há o eutético, resultante da reação

$$
\text { Líquido } \rightarrow \text { Al }+\alpha \text {-AlMnSi (linha bc da Figura 1). }
$$

Para taxas de resfriamento de $11^{\circ} \mathrm{C} / \mathrm{min}$ e de $70^{\circ} \mathrm{C} / \mathrm{min}$ há um refinamento da microestrutura bruta de fundição. Simultaneamente, há um aumento da quantidade de $\alpha$ AlMnSi e diminuição de $\mathrm{Al}_{6} \mathrm{Mn}$.

A reação: Líquido $+\mathrm{Al}_{6} \mathrm{Mn} \rightarrow \mathrm{Al}+\alpha-\mathrm{Al}_{12} \mathrm{Mn}_{3} \mathrm{Si}$ ocorre a $649^{\circ} \mathrm{C}$ e em temperaturas menores todas as reações levam à formação de $\alpha-\mathrm{Al}_{12}(\mathrm{Mn}, \mathrm{Fe})_{3} \mathrm{Si}$ como um dos produtos resultantes. Para temperaturas menores que $648^{\circ} \mathrm{C}$ a fase $\alpha-\mathrm{Al}_{12}(\mathrm{Mn}, \mathrm{Fe})_{3} \mathrm{Si}$ é mais estável que $\mathrm{Al}_{6}(\mathrm{Mn}, \mathrm{Fe})$ [Mathew et al, 1984]. 


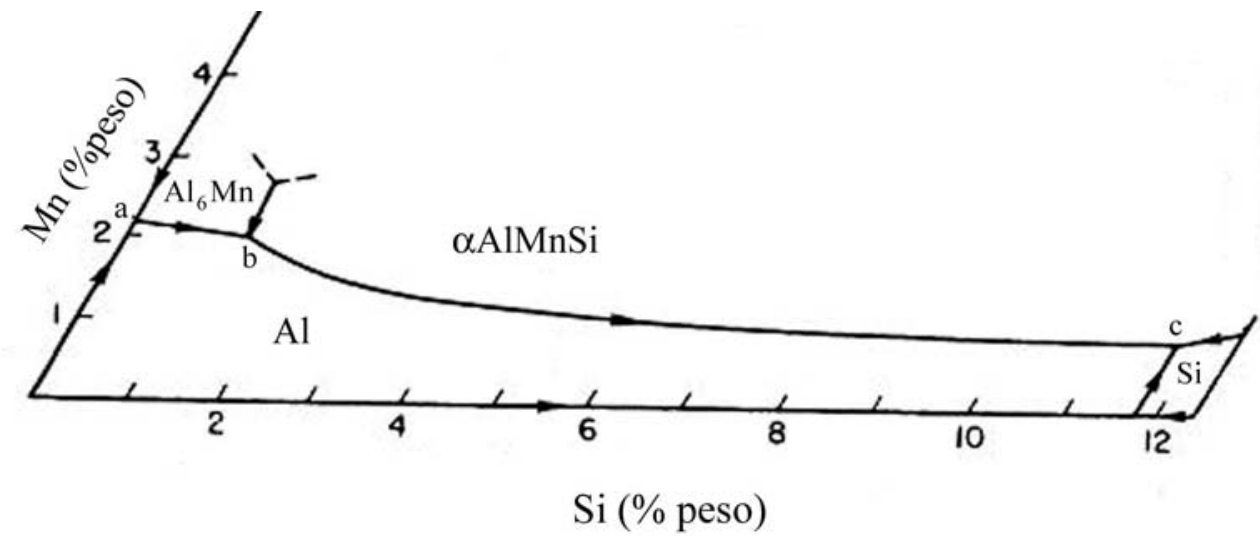

Figura 1- Diagrama de fases de equilíbrio (superfície liquidus) do sistema Al-Mn-Si [Sperry, 1955].

\subsubsection{Homogeneização}

O tratamento térmico de homogeneização visa principalmente eliminar ou diminuir gradientes de concentração das soluções sólidas de microestruturas brutas de fundição [Falleiros, 1970]. No caso da liga de alumínio 3003, o tratamento térmico de homogeneização leva à precipitação e à transformação de fase. A homogeneização fazse necessária para solubilizar e redistribuir os elementos solúveis [Verlinden et al, 1990], principalmente os eutéticos de baixo ponto de fusão que podem provocar o aparecimento de trincas durante posterior conformação mecânica [Polmear, 1989]. Durante a homogeneização ocorre também a precipitação, pois a estrutura bruta de fundição tem regiões supersaturadas [Falleiros, 1970]. Manganês também pode saturar a solução sólida de dendritas primárias e subseqüentemente precipitar como dispersóides na matriz [Davis, 1993; Li and Arneberg, 2002]. Os dispersóides são partículas finas, em geral menores que $0,1 \mu \mathrm{m}$ e a sua presença na microestrutura do material durante tratamento térmico causa atraso na recristalização [Padilha, 2003]. Os dispersóides são formados após posterior recozimento da liga bruta de fundição, enquanto as partículas primárias 
são provenientes do processo de solidificação. A quantidade e tamanho dos compostos intermetálicos formados nas regiões interdendríticas dependem principalmente da quantidade de soluto e das condições de solidificação. Em geral eles têm dimensões que vão desde $1 \mu \mathrm{m}$ até dezenas de micrometros [Padilha, 2003].

A liga 3003 contém partículas primárias de $\mathrm{Al}_{6}(\mathrm{Mn}, \mathrm{Fe})$ e $\alpha-\mathrm{Al}_{12}(\mathrm{Mn}, \mathrm{Fe})_{3} \mathrm{Si}$, no entanto, a homogeneização a $645^{\circ} \mathrm{C}$ leva a presença apenas da fase cúbica $\alpha$ [Mathew et al, 1984). Furrer [1979] mostra que no recozimento de lingotes obtidos por processo semi-contínuo (DC - Direct-Chill) há uma transformação gradual da fase ortorrômbica $\mathrm{Al}_{6}(\mathrm{Mn}, \mathrm{Fe})$ para a fase cúbica $\alpha-\mathrm{Al}_{12}(\mathrm{Mn}, \mathrm{Fe})_{3} \mathrm{Si}$. A observação de um ponto máximo de resistividade em homogeneização de curta duração $\left(4,97 \mu \Omega \mathrm{cm}\right.$ a $645^{\circ} \mathrm{C} / 30$ minutos) seguido por um leve decréscimo (valor final 4,73 $\mu \Omega \mathrm{cm}$ ) é explicada pela difusão de Fe, Mn e Si para as partículas primárias, sugerindo que a difusão de Fe, Mn e Si para a fase $\mathrm{Al}_{6}(\mathrm{Mn}, \mathrm{Fe})$ converte esta fase na fase estável $\alpha-\mathrm{Al}_{12}(\mathrm{Mn}, \mathrm{Fe})_{3} \mathrm{Si}$ [Hansen et al, 1995]. A transformação de $\mathrm{Al}_{6}(\mathrm{Mn}, \mathrm{Fe})$ para $\alpha$-Al( $\left.\mathrm{Mn}, \mathrm{Fe}\right) \mathrm{Si}$ envolve nucleação da fase $\alpha$ na interface entre partículas de $\mathrm{Al}_{6}(\mathrm{Mn}, \mathrm{Fe})$ e a matriz $\mathrm{Al}$ [Alexander et al, 2002]. Pettersen et al [2002] sugerem que alguns precipitados $\mathrm{Al}_{6}(\mathrm{Mn}, \mathrm{Fe}$ ) (formados durante a solidificação) se transformarão em $\mathrm{Al}_{15}(\mathrm{Mn}, \mathrm{Fe})_{3} \mathrm{Si}$ durante a homogeneização, enquanto Li [2003 a] sugere que se transformarão em $\mathrm{Al}_{15}(\mathrm{Mn}, \mathrm{Fe})_{3} \mathrm{Si}_{2}$, ou seja, sugerem que a composição da fase $\alpha-\mathrm{Al}(\mathrm{Mn}, \mathrm{Fe}) \mathrm{Si}$ é $\mathrm{Al}_{15}(\mathrm{Mn}, \mathrm{Fe})_{3} \mathrm{Si}$ ou $\mathrm{Al}_{15}(\mathrm{Mn}, \mathrm{Fe})_{3} \mathrm{Si}_{2}$ e não $\mathrm{Al}_{12}(\mathrm{Mn}, \mathrm{Fe})_{3} \mathrm{Si}$.

A Figura 2 mostra que a transformação da fase $\mathrm{Al}_{6}(\mathrm{Mn}, \mathrm{Fe})$ em fase $\alpha$ $\mathrm{Al}(\mathrm{Mn}, \mathrm{Fe}) \mathrm{Si}$ começa a $400^{\circ} \mathrm{C}$ e a fração em área da fase $\alpha-\mathrm{Al}(\mathrm{Mn}, \mathrm{Fe}) \mathrm{Si}$ nas partículas primárias aumenta com a temperatura. 


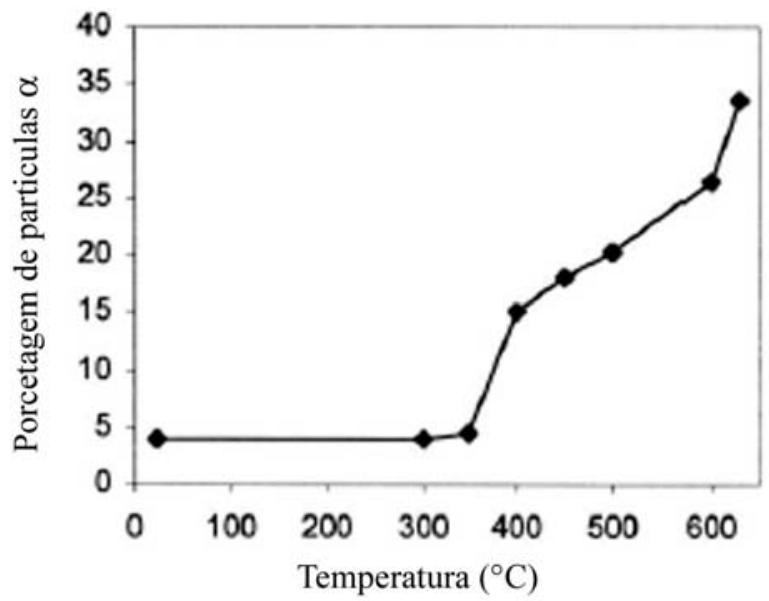

Figura 2 - Porcentagem da fase $\alpha-\mathrm{Al}(\mathrm{Mn}, \mathrm{Fe}) \mathrm{Si}$, em relação ao total de partículas primárias, durante aquecimento [Li, $2003 \mathrm{a}]$.

Durante a homogeneização, a fração em área de partículas primárias aumenta com o tempo enquanto a densidade diminui como mostra a Figura 3, indicando que durante a homogeneização as partículas vão se tornando mais grossas, ou seja, com o tempo, as partículas crescem.

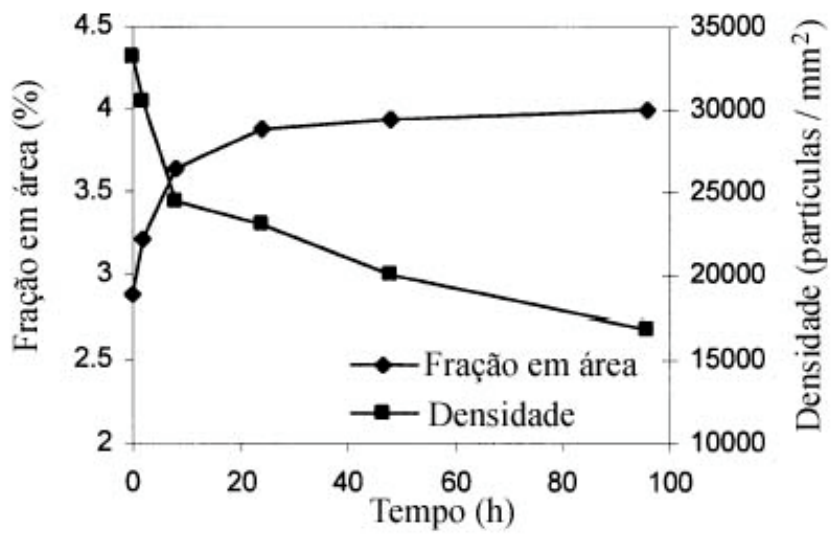

Figura 3 - Variações da fração em área e da densidade de partículas primárias (número de partículas $/ \mathrm{mm}^{2}$ ) durante homogeneização a $600^{\circ} \mathrm{C}$ [Li, $\left.2003 \mathrm{a}\right]$.

A variação da razão $\mathrm{Mn} /(\mathrm{Mn}+\mathrm{Fe})$ nas partículas primárias durante homogeneização é mostrada na Figura 4. A razão $\mathrm{Mn} /(\mathrm{Mn}+\mathrm{Fe})$ aumenta com o tempo de homogeneização, e aumenta mais rapidamente no período inicial da homogeneização. 
Os átomos de $\mathrm{Fe}$ e $\mathrm{Mn}$ são substitucionais nas partículas primárias de $\mathrm{Al}_{6}(\mathrm{Mn}, \mathrm{Fe})$ e $\alpha$ $\mathrm{Al}(\mathrm{Mn}, \mathrm{Fe}) \mathrm{Si}$, e a quantidade de $\mathrm{Mn}$ em dispersóides é muito maior do que nas partículas primárias. Durante homogeneização, a deposição de Mn supersaturado sobre partículas primárias e a dissolução de dispersóides ricos em Mn causam o aumento da quantidade de $\mathrm{Mn}$ nas partículas primárias. Portanto, a razão $\mathrm{Mn} /(\mathrm{Mn}+\mathrm{Fe})$ é aumentada.

Segundo Polmear [1989], é importante que a taxa de aquecimento para o tratamento térmico de homogeneização seja lenta $\left(75^{\circ} \mathrm{C} / \mathrm{h}\right)$ para promover a nucleação e o crescimento de uma fina e uniforme dispersão dos compostos. Estes compostos nucleiam heterogeneamente na superfície dos precipitados maiores formados durante o aquecimento lento.

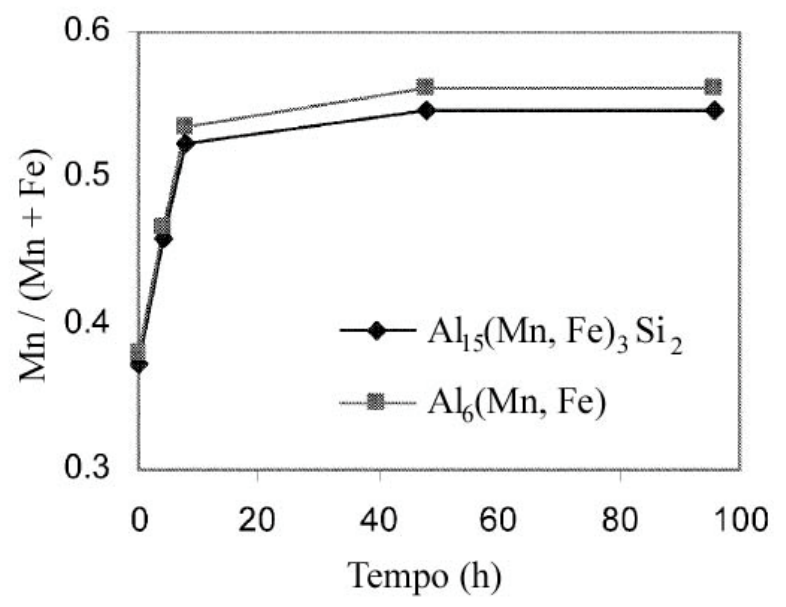

Figura 4 - Razão Mn / (Mn + Fe) (em \% peso / \% peso) de partículas primárias durante homogeneização [Li, 2003 a].

Transformação de fase em precipitados parece ter um efeito decisivo no tamanho e distribuição de dispersóides e, conseqüentemente, no desenvolvimento da microestrutura e propriedades no sistema Al-Mn-Fe-Si [Hansen et al, 1995]. Nas ligas $\mathrm{Al}-\mathrm{Mn}$, a temperatura de recristalização é afetada pela dispersão de partículas de $\mathrm{Al}_{6} \mathrm{Mn}$ na estrutura homogeneizada, que tem efeito sobre a migração de contornos durante o recozimento e também se pode atribuir importância à dispersão de zonas altamente deformadas na matriz, junto aos precipitados [Falleiros, 1970]. 
Partículas formadas em recozimentos posteriores à solidificação são nucleadas, preferencialmente, nos contornos de subgrão e crescem a partir dos dispersóides por precipitação de elementos supersaturados [Hansen et al, 1995]. Hansen et al [1995] propõe que a fase $\mathrm{Al}_{12} \mathrm{Mn}$ (cúbica de corpo centrado, $\mathrm{a}=0,7487 \mathrm{~nm}$ ) é formada pela reação peritetóide entre a fase $\alpha-\mathrm{Al}(\mathrm{Mn}, \mathrm{Fe}) \mathrm{Si}$ e a matriz alumínio, após tratamento térmico prolongado e temperatura acima de $506^{\circ} \mathrm{C}$.

A diminuição de gradientes de composição ocorre principalmente por difusão. A velocidade de difusão na solução sólida de Al é um fator fundamental que influencia a cinética das reações no estado sólido [Falleiros, 1970].

Li e Arnberg [2002] concluíram que os dispersóides começam a precipitar a $300^{\circ} \mathrm{C}$ durante aquecimento a $50^{\circ} \mathrm{C} / \mathrm{h}$ devido à decomposição da solução supersaturada e que a densidade de dispersóides aumenta com o aumento da temperatura, tendo um máximo a $400^{\circ} \mathrm{C}$, então decresce com o aumento da temperatura e do tempo de homogeneização. A difusão de Mn em solução sólida é um fator importante que controla a precipitação de dispersóides. Quando a liga é tratada termicamente em baixa temperatura, os dispersóides crescem à custa do Mn supersaturado na matriz após terem sido nucleados. Na Tabela 4 encontram-se valores de coeficiente de difusão de alguns elementos que compõem a liga 3003. Estes valores foram calculados com auxílio da equação de Arrhenius e os valores das constantes (fator de freqüência e energia de ativação) foram obtidos em [Brandes, 1983]. Pode-se notar que o coeficiente de difusão do Mn é baixo, como a difusão de Mn em solução sólida controla a precipitação de dispersóides, pode-se concluir que a precipitação é um processo lento.

Tabela 4 - Coeficientes de difusão calculadas, em $\mathrm{cm}^{2} / \mathrm{s}$, dos elementos que compõe a liga 3003 em algumas temperaturas.

\begin{tabular}{|c|c|c|c|c|}
\hline & $\mathrm{Al}$ & $\mathrm{Fe}$ & $\mathrm{Si}$ & $\mathrm{Mn}$ \\
\hline $200^{\circ} \mathrm{C}$ & $\mathbf{2 , 5 7 1 \times \mathbf { 1 0 } ^ { - 1 6 }}$ & $\mathbf{2 , 9 9 2 \times \mathbf { 1 0 } ^ { - 2 3 }}$ & $\mathbf{1 , 8 2 4 \times \mathbf { 1 0 } ^ { - 1 5 }}$ & $5,343 \times 10^{-22}$ \\
\hline $400^{\circ} \mathrm{C}$ & $\mathbf{1 , 4 0 5} \times \mathbf{1 0}^{-11}$ & $\mathbf{8 , 7 1 8 \times 1 0 ^ { - 1 5 }}$ & $\mathbf{5 , 7 3 3 \times \mathbf { 1 0 } ^ { - 1 1 }}$ & $4,455 \times 10^{-15}$ \\
\hline $600^{\circ} \mathrm{C}$ & $5,183 \times 10^{-9}$ & $3,362 \times 10^{-10}$ & $1,567 \times 10^{-8}$ & $2,504 \times 10^{-11}$ \\
\hline
\end{tabular}




\subsection{Processo roll caster}

"Twin roll caster" (TRC) como é conhecido o processo de obtenção de chapas diretamente do metal fundido tem sido usado há quase 50 anos na indústria de alumínio [Lockyer et al, 1996; Yun et al, 2000]. No presente trabalho, o processo TRC será chamado apenas de caster. Geralmente, as ligas comerciais produzidas por caster têm faixas de solidificação estreitas e são produzidas chapas com espessura na faixa de 6 a $10 \mathrm{~mm}$. As ligas normalmente utilizadas por este processo são o alumínio comercialmente puro (série 1000), as ligas Al-Mn (série 3000) e as ligas Al-Fe e AlFeMn (série 8000) [Uriz et al, 2000]. Para as ligas com faixa de solidificação larga, o processo não é adequado porque a tira não seria solidificada ao entrar em contato com os cilindros laminadores [Haga and Suzuki, 2003].

O sistema de vazamento caster consiste na produção de chapas de alumínio a partir da passagem de metal líquido, entre dois cilindros refrigerados a água, combinando solidificação e laminação a quente em uma única operação e o produto final é facilmente bobinado [Cook et al, 1995; Lockyer et al, 1996; Yun et al, 2000]. A solidificação começa quando o metal fundido entra em contato com os cilindros refrigerados. Devido à redução de dimensão progressiva no ponto de mordedura dos cilindros laminadores (ponto de menor separação entre os cilindros), o metal solidificado é forçado a ficar em contato com os cilindros laminadores. Uma vez solidificado, o metal sofre deformação a quente antes de deixar os cilindros laminadores [Cook et al, 1995; Li, 1995; Miyazawa et al, 1981]. Após a solidificação, a redução em casters convencionais pode ser da ordem de 30 a $60 \%$, dependendo do diâmetro dos cilindros laminadores e do comprimento da zona de laminação [Berg et al, 1995].

O processo caster é oferecido como uma alternativa ao convencional lingotamento semicontínuo que é seguido por laminação a quente. As vantagens do caster são o baixo custo do equipamento, economia de energia, economia de espaço e baixo custo de produção [Haga et al, 2004; Liang et al, 1997; Santos et al, 2000]. 


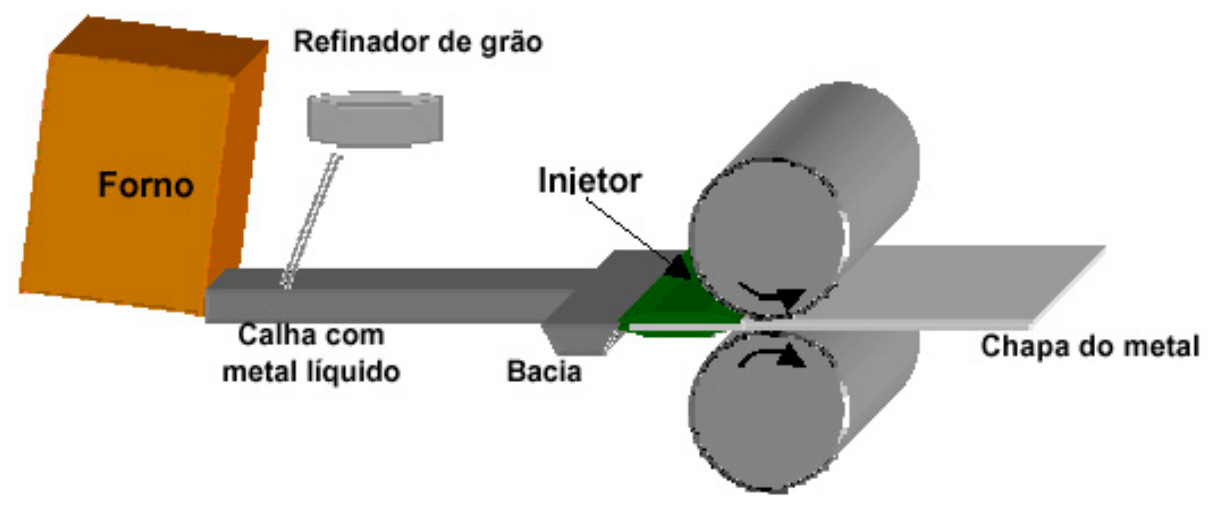

Figura 5 - Desenho esquemático do processo TRC horizontal.

No processo caster, a velocidade de resfriamento é alta, varia de 200 a $700 \mathrm{~K} / \mathrm{s}$, portanto a velocidade de solidificação também é alta, dando lugar a uma matriz de alumínio com alto grau de saturação dos elementos de liga e impurezas e com partículas primárias relativamente pequenas [Uriz et al, 2000]. A alta taxa de resfriamento (2 a 3 ordens de grandeza maior do que o método convencional) oferece propriedades mecânicas melhores ao material e diferenças microestruturais obtidas pelos dois métodos [Berg et al, 1995; Haga and Suzuki, 2003; Saitoh et al, 1989; Slamova et al, 2003]. O gradiente de temperatura é muito maior próximo à superfície do que no centro da chapa fundida, portanto o tempo de solidificação e a microestrutura apresentarão variação ao longo da espessura [Berg et al, 1995].

Atualmente, a velocidade para se produzir uma chapa de alumínio de 5 a $7 \mathrm{~mm}$ de espessura é de $1 \mathrm{~m} / \mathrm{min}$. Velocidades de $10 \mathrm{~m} / \mathrm{min}$ têm sido obtidas utilizando-se cilindros laminadores com grande diâmetro, e, recentemente, velocidades de $15 \mathrm{~m} / \mathrm{min}$ foram obtidas para tiras de $1 \mathrm{~mm}$ de espessura. A velocidade do caster pode ser aumentada pelo aumento da taxa de resfriamento, por isso, chapas mais finas podem ser produzidas mais rapidamente [Haga and Suzuki, 2003]. Alguns autores [Haga et al, 2004; Haga and Suzuki, 2003] propuseram um novo sistema de caster chamado de melt drag twin roll caster que utiliza cilindros de cobre sem lubrificantes (que possui condutividade térmica maior que o aço, resultando em uma transferência de calor mais eficiente entre fundido e cilindro, dispensando o uso de lubrificantes) podendo chegar a velocidades de $60 \mathrm{~m} / \mathrm{min}$. 
É muito comum serem encontrados trabalhos de simulações do processo caster na literatura, pois, embora o caster apresente várias vantagens, ainda é necessário desenvolver uma ferramenta numérica eficiente para elucidar os complicados fluxos e mecanismos de transferência de calor, que podem ser utilizados para desenvolver um sistema caster otimizado [Liang et al, 1997; Santos et al, 2000].

\subsection{Deformação, recristalização e precipitação em ligas Al-Mn}

Neste capítulo foi dada ênfase à forma como a energia é armazenada no material durante a deformação, e como esta energia é liberada na recuperação. Posteriormente, a recristalização é abordada em termos de nucleação e crescimento, com ênfase no papel das partículas de segunda fase. A precipitação durante a recristalização também é discutida.

\subsection{1 - O estado encruado}

A quantidade de energia armazenada durante a deformação plástica fornece o potencial termodinâmico para a recuperação e a recristalização e, portanto, a microestrutura no estado encruado de certo modo controla o desenvolvimento, o crescimento e a orientação dos núcleos que irão se tornar grãos recristalizados [Martins, 2002]. A energia de uma discordância depende de como ela se encontra distribuída no material, ou seja, da sua interação com outras discordâncias da vizinhança. Este valor é máximo para uma discordância isolada e muito menor quando as discordâncias se encontram nas paredes ou contornos de células ou subgrãos. As subestruturas de discordâncias desenvolvidas durante a deformação plástica de um metal dependem da estrutura cristalina, da temperatura, da deformação aplicada, da composição química, do modo, da taxa de deformação e da orientação cristalográfica dos grãos.

Durante a deformação plástica de metais, em grãos de diferente orientação, diferentes quantidades de sistemas de deslizamento são acionados e ocorrem diferentes 
interações entre os sistemas de deslizamento e conseqüentemente armazenam diferentes quantidades de energia na forma de defeitos cristalinos. Quantificar a energia armazenada em função da orientação é muito importante para se entender e predizer a cinética de recristalização e a textura. Borbély e Driver [2001] quantificaram a energia armazenada para algumas orientações da liga Al-2,5\% Mg laminada a quente. Grãos com textura tipo cubo apresentaram a menor densidade de discordâncias, o que está de acordo com sua alta taxa recuperação. As componentes estáveis tipo Goss e Latão também apresentaram baixos valores, embora maior que a orientação tipo cubo. A maior energia armazenada, aproximadamente 3,5 J/mol, foi encontrada na componente $\mathrm{S}$, comparada com aproximadamente $1 \mathrm{~J} / \mathrm{mol}$ para as outras componentes.

Outro fator de grande importância é a energia de defeito de empilhamento (EDE). A distribuição de discordâncias em um metal encruado depende fortemente de sua EDE [Martins, 2002]. Metais de baixa EDE apresentam microestruturas com distribuição mais homogênea de discordâncias. Metais de alta EDE tendem a apresentar distribuição heterogênea de discordâncias, chamada de estrutura celular de discordâncias. Este tipo de estrutura apresenta regiões que alternam altas e baixas densidades de discordâncias no material. O alumínio é um metal CFC que apresenta elevada EDE (acima de $150 \mathrm{~mJ} / \mathrm{m}^{2}$ ), de modo que na deformação a frio, uma estrutura celular de discordâncias é formada para deformações maiores de 0,1 [Gonçalves, 2003]. Além da subestrutura celular de discordâncias, o alumínio e suas ligas podem apresentar outras heterogeneidades mais acentuadas na distribuição de defeitos cristalinos após a deformação, denominadas aqui genericamente como bandas de deformação. Essas heterogeneidades apresentam altas concentrações de defeitos cristalinos e consideráveis variações de diferenças de orientação (dezenas de graus) entre regiões distantes poucos micrometros entre si, dentro de um mesmo grão. Elas são em geral locais preferenciais para o início (nucleação) da recristalização [Padilha et al, 2003].

A presença de elementos em solução sólida altera a EDE do metal inicialmente puro, alterando a distribuição das discordâncias e, por conseguinte, as propriedades deste material [Padilha et al, 1996]. Quando é adicionado soluto ao metal, ele se torna mais resistente, pois a movimentação de discordâncias é dificultada. 
A presença de partículas de segunda fase, geralmente, aumenta a energia armazenada na proporção da fração volumétrica de partículas e também da quantidade de deformação aplicada e inversamente proporcional ao tamanho das partículas. Para entender este efeito é importante considerar a distribuição de discordâncias que é desenvolvida nestes sistemas durante a deformação [Martin et al, 1997].

Ashby [1966] observou que se uma fase dispersa, na forma de pequenas partículas, deforma-se menos que a matriz (ou não se deforma), ocorrem gradientes de deformação dentro do material. Para acomodar gradientes de deformação impostos pela microestrutura em materiais plasticamente não homogêneos, discordâncias “geometricamente necessárias" são armazenadas na matriz, próximas aos precipitados.

A Figura 6 resume a interpretação de Ashby sobre discordâncias geometricamente necessárias. Na Figura 6a há um elemento de volume do cristal não deformado contendo uma inclusão indeformável de segunda fase. $\mathrm{Na}$ Figura $6 \mathrm{~b}$ a inclusão é removida e o cristal é cisalhado uniformemente; como a inclusão é indeformável, o buraco tem que ter sua forma restaurada para que a inclusão possa ser recolocada.

As Figuras 6c e 6d mostram a restauração da forma original através de anéis de cisalhamento, respectivamente, nos sistemas primários e secundários. Este processo leva à curvatura local do reticulado na matriz nesta região. Nas Figuras 6e e $6 \mathrm{f}$ a restauração se dá pela formação de anéis prismáticos de discordâncias, que não levam à curvatura local do reticulado, mas são susceptíveis de rearranjos do tipo recuperação [Padilha et al, 2003; Martin et al, 1997]. 


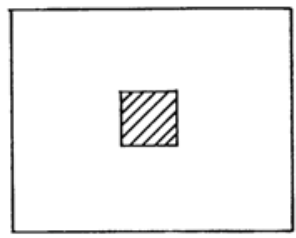

(a)

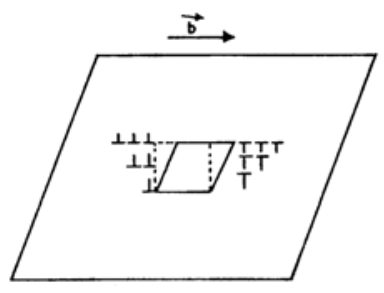

(c)

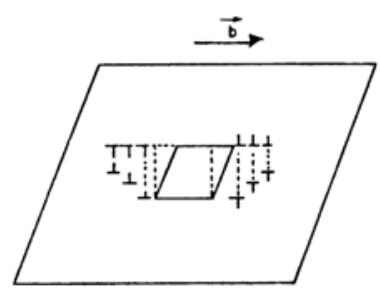

(e)

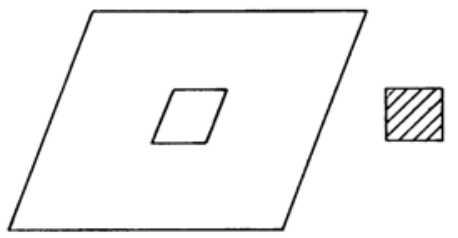

(b)

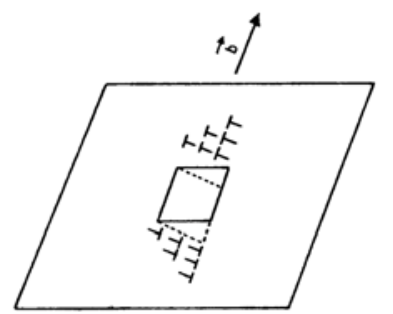

(d)

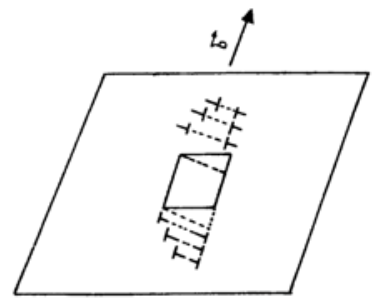

(f)

Figura 6: Arranjos esquemáticos de discordâncias geometricamente necessárias formadas ao redor de precipitados durante a deformação plástica [Ashby, 1971].

As ligas de alumínio podem ser divididas em dois grandes grupos: ligas tratáveis termicamente e ligas não tratáveis termicamente. As ligas tratáveis termicamente são ligas das séries $2 \mathrm{XXX}, 6 \mathrm{XXX}$ e $7 \mathrm{XXX}$, onde o acentuado aumento das propriedades mecânicas se deve à precipitação de partículas de segundas fases (endurecimento através do tratamento de solubilização seguido de envelhecimento), que atuam como barreiras à movimentação de discordâncias, aumentando a resistência da liga. As ligas não tratáveis termicamente são ligas das séries $1 \mathrm{XXX}, 3 \mathrm{XXX}$ e $5 \mathrm{XXX}$ que são endurecíveis apenas por trabalho mecânico, onde o incremento nas propriedades mecânicas se dá através da deformação plástica (através do encruamento). A liga 3003 é a mais amplamente utilizada das ligas com adição de Mn. A presença de compostos intermetálicos contendo manganês confere endurecimento por dispersão de partículas incoerentes. As partículas 
de segunda fase nesta liga são grandes, incoerentes e não cisalháveis. $\mathrm{O}$ endurecimento por dispersão segue o modelo de Orowan, as discordâncias podem evitar as partículas por escalada ("climb") ou escorregamento com desvio ("cross-slip"), ou mesmo curvarse entre partículas, podendo provocar a formação de anéis de discordâncias ao redor das partículas. No estado recozido, o limite de resistência da liga 3003 é $110 \mathrm{MPa}$ comparado com $90 \mathrm{MPa}$ para o alumínio comercialmente puro [Polmear, 1989]. No caso de ligas tratáveis termicamente as partículas são coerentes, finas (normalmente com diâmetro menor que $0,1 \mu \mathrm{m}$ ) e cisalháveis. O endurecimento é provocado por estas partículas coerentes, que são cizalhadas durante a deformação plástica.

\subsection{2 - Recuperação}

Como já foi dito na seção anterior, durante a deformação a energia é armazenada no material principalmente na forma de discordâncias. Esta energia é liberada em três processos principais: recuperação, recristalização e crescimento de grão.

A recuperação compreende fenômenos que levam a restauração parcial da microestrutura do material proveniente da deformação plástica [Blum et al, 1996]. Na recuperação o processo de diminuição de energia armazenada não envolve movimento de contornos de alto ângulo [Doherty et al, 1997].

Durante a recuperação, a energia armazenada é diminuída pela movimentação de discordâncias. Existem dois processos principais: a aniquilação de discordâncias (discordâncias em planos de escorregamento diferentes, que combinam escorregamento e escalada, para se aniquilar e/ou discordâncias no mesmo plano de escorregamento de sinais opostos deslizam uma em direção a outra para se aniquilar) e o rearranjo de discordâncias em configurações de menor energia. Os dois processos envolvem os mecanismos de escorregamento, escalada e escorregamento com desvio de discordâncias. Com a subseqüente aniquilação de discordâncias durante recozimento, o excesso de discordâncias de mesmo sinal tende a se rearranjar em configurações de menor energia, este modelo é conhecido como poligonização. A formação dos subcontornos foi inicialmente proposta por este modelo. 
Em temperaturas maiores que $0,2 \mathrm{~T}_{\mathrm{f}}$ (temperatura de fusão absoluta), ocorre principalmente a aniquilação de lacunas e a migração de defeitos puntiformes para contornos de grão e discordâncias. Temperaturas na faixa de 0,2 a $0,3 T_{f}$ promovem a aniquilação de discordâncias de sinais opostos assim como o rearranjo das mesmas, delineando os subcontornos de grão, também denominados contornos de baixo ângulo [Humphreys, 1995]. A formação de subgrãos requer maior ativação térmica devido à necessidade de ocorrência em grande escala de escorregamento com desvio e escalada, acontecendo geralmente em temperaturas maiores que 0,4 $\mathrm{T}_{\mathrm{f}}$ [Padilha et al, 1996; Martin et al, 1997].

A extensão da recuperação depende da facilidade com que a recristalização pode ocorrer. Conseqüentemente, pelo fato da recuperação diminuir o potencial para a recristalização, uma quantidade significativa de recuperação influencia a natureza e a cinética de recristalização. A extensão da recuperação é afetada pela quantidade de deformação, pela temperatura de recozimento, pela taxa de aquecimento e pela natureza do material [Humphreys, 1995]. O nível de recuperação é dependente da EDE uma vez que esta controla a habilidade de discordâncias sofrerem escorregamento com desvio ou escalada. A presença de solutos pode diminuir o nível de recuperação, pela diminuição da EDE ou pela criação de uma atmosfera de átomos de soluto que reduz a mobilidade das discordâncias [Mcqueen et al, 1991].

\subsection{3 - Recristalização}

A recristalização envolve a formação de uma microestrutura formada por novos grãos, e seu subseqüente crescimento, de modo a consumir a estrutura deformada ou parcialmente recuperada. A recristalização descontínua é definida como a eliminação de defeitos através da migração de contornos de alto ângulo. Algumas ligas encruadas podem amolecer consideravelmente durante o recozimento sem que ocorra formação e migração de contornos de alto ângulo. Este processo é conhecido como recristalização contínua [Doherty et al, 1997]. Basicamente, a recristalização envolve as etapas de nucleação e crescimento. 


\subsubsection{1 - Nucleação}

A formação de um núcleo de recristalização é termodinamicamente possível, uma vez que o aumento de energia devido à criação da interface núcleo/matriz é compensado pelo abaixamento da energia devido à eliminação de defeitos [Pimenta, 1985]. Os locais preferenciais de nucleação dos novos grãos se situam sobre as zonas de grande deformação, como as heterogeneidades de deformação. As heterogeneidades como bandas de transição, de cisalhamento e maclas de deformação têm alta energia armazenada, sendo locais preferenciais para formação de núcleos de recristalização, pois possuem grande quantidade de defeitos e grandes distorções no reticulado. Os modelos de nucleação são descritos sucintamente em seguida.

\section{Nucleação por migração de subcontornos}

O modelo de nucleação por migração de subcontornos foi proposto por Cahn (1949, 1950) e Beck (1949) e admite que a migração é termicamente ativada e os subcontornos em migração absorvem discordâncias, aumentando sua energia, sua diferença de orientação $(\psi)$ e sua mobilidade. Eventualmente, $\psi$ pode aumentar e adquirir caráter de um contorno de alto ângulo (alta mobilidade), o que caracteriza a nucleação para recristalização [Martins, 2002].

A migração de subcontornos está associada a altas deformações, a distribuição heterogênea de tamanhos de subgrão, a temperaturas relativamente altas e a metais de baixa EDE [Humphreys, 1995].

\section{Nucleação por coalescimento de subgrão}

O coalescimento de subgrãos ocorre devido à rotação dos subgrãos de tal maneira que os reticulados de subgrãos vizinhos passam a ser coincidentes. É um mecanismo que elimina subcontornos, aumentando o tamanho de subgrão e altera as 
diferenças de orientação entre o grupo de subgrãos que coalescem e seus vizinhos. Este processo mostra-se mais lento que a migração de subcontornos e também é termicamente ativado.

O coalescimento está em geral associado a bandas de transição, a distribuições largas de diferenças de orientação de subgrãos, a deformações moderadas, a regiões vizinhas a contornos de grãos, a temperaturas de recozimento baixas e a metais com alta EDE [Humphreys, 1995].

Nucleação por migração de contorno de grão pré-existente induzida por deformação (SIBM - Strain Induced boundary migration)

Este mecanismo foi observado inicialmente em microscopia óptica por Beck e Sperry [1950]. Este mecanismo envolve a migração de um contorno de grão préexistente para o interior de um grão mais deformado. A condição para que o processo possa ocorrer é o balanço energético favorável entre a redução da energia armazenada devido à eliminação de defeitos e o aumento da superfície total do contorno de grão devido ao embarrigamento (“bulge”) do contorno que está avançando sobre o grão mais deformado. A migração de contornos existentes antes da deformação é induzida por diferença de deformação entre os dois grãos vizinhos. A migração se dá do grão menos deformado para o mais deformado. Isto leva a uma redução da energia livre, que é equivalente à diferença entre a energia liberada devido à diminuição da densidade de defeitos na região varrida pelo contorno e a energia referente ao aumento de superfície do contorno.

Borbély e Driver [2001], em relação ao desenvolvimento de textura de recristalização em ligas CFC laminadas a quente, afirmam que a baixa energia armazenada da componente cubo facilitará sua nucleação e micro-crescimento por SIBM. 


\subsubsection{2 - Crescimento de novos grãos na recristalização}

Como foi visto no item anterior, o processo de nucleação da recristalização requer que um núcleo em potencial seja capaz de crescer sobre a microestrutura não recristalizada. O crescimento das regiões livres de defeitos se dá pela migração de contornos de alto ângulo, portanto o entendimento dos fatores que influenciam a mobilidade dos contornos é de extrema importância.

Durante a recristalização o contorno de alto ângulo move-se no seu sentido côncavo, conforme demonstrado na Figura 7 , há um fluxo de átomos da região deformada para a região recristalizada. Para que isto ocorra, os átomos devem individualmente vencer uma barreira de ativação, ligada ao atrito interno (mobilidade) entre os átomos da estrutura.

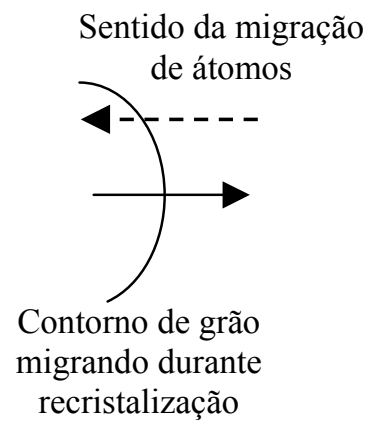

Figura 7 - Desenho esquemático mostrando o sentido de migração do contorno de grão e de átomos para que ocorra a recristalização.

A velocidade de migração, $\mathrm{V}$, é freqüentemente apresentada de uma forma simplificada com função da mobilidade dos contornos, m, e o potencial termodinâmico para transformação:

$\mathrm{V}=\mathrm{m} \Delta \mathrm{P}$

Todavia, esta equação não deixa explícita a influência da orientação cristalográfica, que tem considerável importância. A velocidade de migração varia com 
o ângulo de desorientação (diferença de orientação entre 2 grãos vizinhos ou $\Psi$ ). Dentro de uma ampla variação de orientações apresentadas pelos contornos, pode-se observar intervalos distintos de mobilidade. Para diferença de orientação abaixo de $5^{\circ}$ (subcontornos) a mobilidade pode aumentar ou diminuir com o aumento da desorientação para contornos mistos ou contornos inclinados (tilt), respectivamente [Padilha et al, 1996]. A partir de um valor de $\Psi$ de aproximadamente $15^{\circ}$, a mobilidade aumenta com o ângulo de desorientação. Portanto, contorno de baixo ângulo tem pequena mobilidade enquanto contorno de alto ângulo tem alta mobilidade.

A energia de ativação para migração de contornos de baixo ângulo é muito próxima da energia de ativação para difusão, sugerindo que o processo seja controlado pelo mecanismo de escalada ( $\operatorname{limb}$ ). Por outro lado, a energia de ativação para migração de contornos de alto ângulo é muito menor, cerca de 3/5 da energia de ativação para migração de contornos de baixo ângulo, indicando que a movimentação desses contornos é controlada pela transferência de átomos através do contorno em migração [Padilha et al, 1996], como foi mostrado na Figura 7.

Os fatores que influenciam a mobilidade de subcontornos são temperatura, uma vez que o mecanismo fundamental é escalada, e a diferença de orientação. Já os fatores que influenciam a mobilidade de contornos de alto ângulo são temperatura, concentração de impurezas, orientação relativa entre dois grãos e relação de simetria (CSL Coincidente Site Lattice). Para altas concentrações de soluto, a mobilidade do contorno é baixa e decresce com o aumento da concentração (a velocidade do contorno é controlada pela taxa de difusão dos átomos de soluto). Para baixas concentrações de soluto, a mobilidade é alta e o soluto tem pouca influência na mobilidade do contorno [Martin et al, 1997].

A microestrutura composta de grãos recristalizados, após o término da recristalização primária, ainda não é a mais estável. Com a continuidade do tratamento térmico, a quantidade de contornos passa a fornecer o potencial termodinâmico para o crescimento de grão, de modo a diminuir o número de grãos por unidade de volume, isto é, reduzir a área total dos contornos [Humphreys et al, 1995; Padilha et al, 1996]. 
A redução da área total dos contornos pode ocorrer de forma contínua, processo que é chamado de crescimento de grão; ou de forma descontínua, processo conhecido como crescimento anormal de grão ou recristalização secundária.

\subsubsection{3 - Influência das partículas durante recristalização}

Em ligas de alumínio que contenham precipitados grosseiros $(>1 \mu \mathrm{m})$ antes da deformação, pode ser observada a nucleação da recristalização em torno das partículas. Este efeito é a nucleação estimulada por partícula (PSN - Particle Stimulated Nucleation) e se deve à alta energia armazenada ao redor dos precipitados e durante o recozimento estes defeitos formam subcontornos móveis. Durante o recozimento, ocorre crescimento do subgrão consumindo a região deformada formando contornos de alto ângulo, ao redor da partícula, tornando-se núcleos de recristalização e aptos para crescer. Este processo geralmente leva a uma textura ao acaso [Low, 2000], ou seja, textura cristalográfica muito fraca.

Dispersão de partículas tem grande influência na cinética de recristalização e no tamanho de grão final. Precipitados dispersos pequenos e próximos uns dos outros efetivamente retardam a recristalização devido ao impedimento da movimentação da frente de reação pelas partículas, tanto de subcontornos como de contornos de alto ângulo. Enquanto que inclusões grosseiras e com grande espaçamento entre as partículas $(>4 \mu \mathrm{m})$ aceleram o processo de recristalização devido ao aumento da taxa de nucleação. A transição de retardamento para aceleração ocorre para espaçamento entre partículas de aproximadamente 1 a 2 vezes o tamanho de célula da microestrutura deformada [Hausch et al, 1978].

Como foi dito acima, a aceleração da recristalização em ligas com precipitados grandes está associada ao aumento da taxa de nucleação. Se o espaçamento interpartículas for suficientemente grande de modo a não interferir muito na movimentação de subcontornos e na formação de núcleos, o aumento da fração 
volumétrica das partículas causa um aumento na taxa de nucleação e conseqüentemente, aceleração da recristalização.

No caso das ligas de alumínio contendo $\mathrm{Mn}$, a segregação dos átomos de $\mathrm{Mn}$ para a rede de discordâncias e a aglomeração de átomos de soluto efetivamente dificultam o rearranjo de estrutura celular de discordâncias e a formação de núcleos potenciais de recristalização. A temperatura de recristalização adequada depende da quantidade de Mn em solução sólida [Koster, 1974], um aumento de Mn em solução sólida causa um aumento de temperatura necessária para que a recristalização ocorra.

Segundo Zener [1948], a força que um precipitado esférico exerce num contorno dificultando seu movimento é dada pela equação:

$F_{p}=\frac{3 \gamma f}{2 r}$

onde, $\gamma$ é a energia de superfície do contorno de grão, $f$ é fração volumétrica dos precipitados e r é o raio do precipitado.

A resistência ao movimento do contorno exercida pelas partículas, portanto é proporcional a f/r, ou seja, quanto mais fina a dispersão maior é a força retardadora.

\subsubsection{4 - Precipitação durante a recristalização}

Em ligas supersaturadas e deformadas pode ocorrer a precipitação de partículas de segunda fase na mesma faixa de temperatura em que ocorre a recristalização, sendo que ambos fenômenos influenciam-se mutuamente. A Figura 8 mostra a ordem de ocorrência dos dois processos. Nota-se que em temperaturas de recozimento maiores que $T_{1}$ ocorre apenas a recristalização sem precipitação. Em temperaturas entre $T_{1}$ e $T_{2}$ há ocorrência de precipitação ao término da recristalização. Para recozimentos em temperaturas menores que $T_{2}$, a precipitação de partículas ocorre antes da recristalização, influindo no rearranjo de discordâncias durante a recuperação e na migração dos contornos de baixo e alto ângulo. Dessa forma, a recristalização é atrasada 
quando ocorre a precipitação de partículas no material, em temperaturas menores que $\mathrm{T}_{2}$ [Padilha et al, 1996].

Geralmente ligas comerciais de grãos finos são obtidas quando a recristalização ocorrer anterior a precipitação.
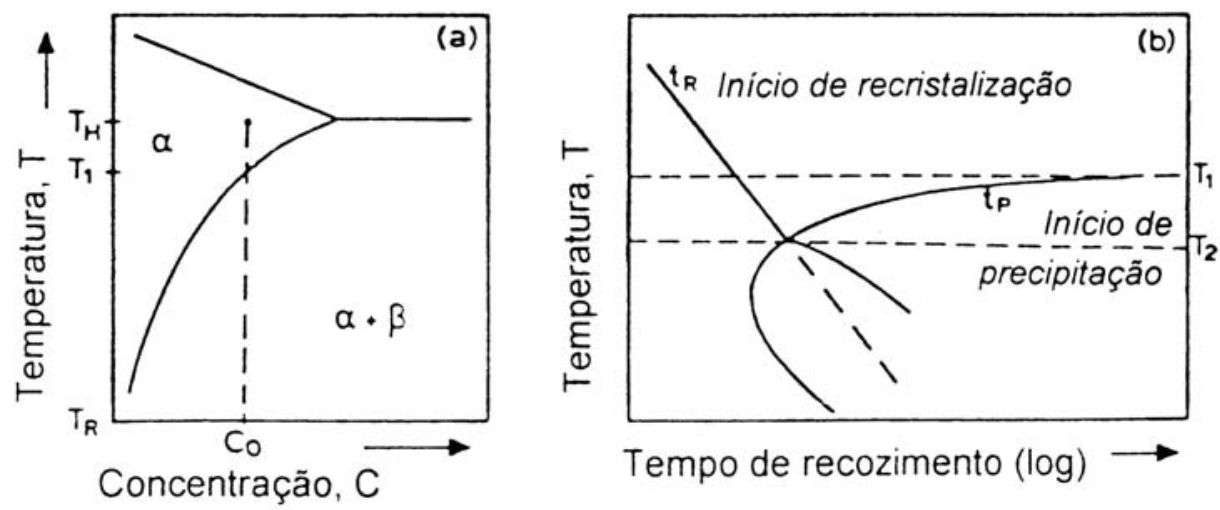

Figura 8 - Ordem de ocorrência da recristalização e precipitação em ligas supersaturadas. (a) Diagrama de fases esquemático de liga de concentração $\mathrm{C}_{0}$ solubilizada e deformada a temperatura ambiente no estado supersaturado. (b) Curva TTT envolvendo precipitação e recristalização [Padilha et al, 1996; Haessner, 1978].

As características de recristalização e precipitação Al-Mn-Si são alteradas com a adição de Si, principalmente na cinética de precipitação. A adição de Si acelera a taxa de decomposição de solução sólida supersaturada. A precipitação da fase $\alpha \mathrm{AlMnSi}$ ocorre antes da recristalização da matriz deformada, apresentando espaçamento entre partículas da ordem de 0,8 a 1,5 $\mu \mathrm{m}$, impedindo a recristalização como já foi dito [Hausch et al, 1978].

\subsection{Textura}

A orientação cristalográfica, ou simplesmente textura, refere-se a como os planos atômicos estão posicionados em relação a um sistema de referência fixo. 
A existência ou não de textura num material depende de como as orientações dos grãos se distribuem no material. Considera-se um metal com ausência da textura quando a distribuição das orientações dos cristais no agregado policristalino é aleatória. Contudo, normalmente as diferentes etapas de processamento dos metais (solidificação, deformação plástica e recristalização, por exemplo) conduzem à formação de uma distribuição de orientação preferencial onde predominam determinados eixos cristalográficos. Portanto, a distribuição de orientação em um policristal é resultado do processo de fabricação e com isso, a textura contém informações sobre o histórico de produção do material. A textura apresenta forte efeito nas propriedades do metal e revela a relação entre parâmetros de processamento do material e seu desempenho.

Alguns grãos sofrem pronta recristalização, enquanto outros, intensa recuperação indicando que o potencial e a cinética de recristalização variam de grão para grão. Esta variação pode estar relacionada à orientação cristalográfica dos grãos, uma vez que determinadas orientações armazenam mais energia que outras durante a deformação plástica, pois são mais instáveis - estão orientadas mais favoravelmente para a deformação plástica - durante a conformação. Por outro lado, existem determinadas orientações cristalográficas que durante deformação plástica se comportam de modo bastante homogêneo, desse modo armazenam menor energia e durante subseqüente tratamento térmico sofrem apenas intensa recuperação [Sandim e Martins et al, 2001; 2004]. 


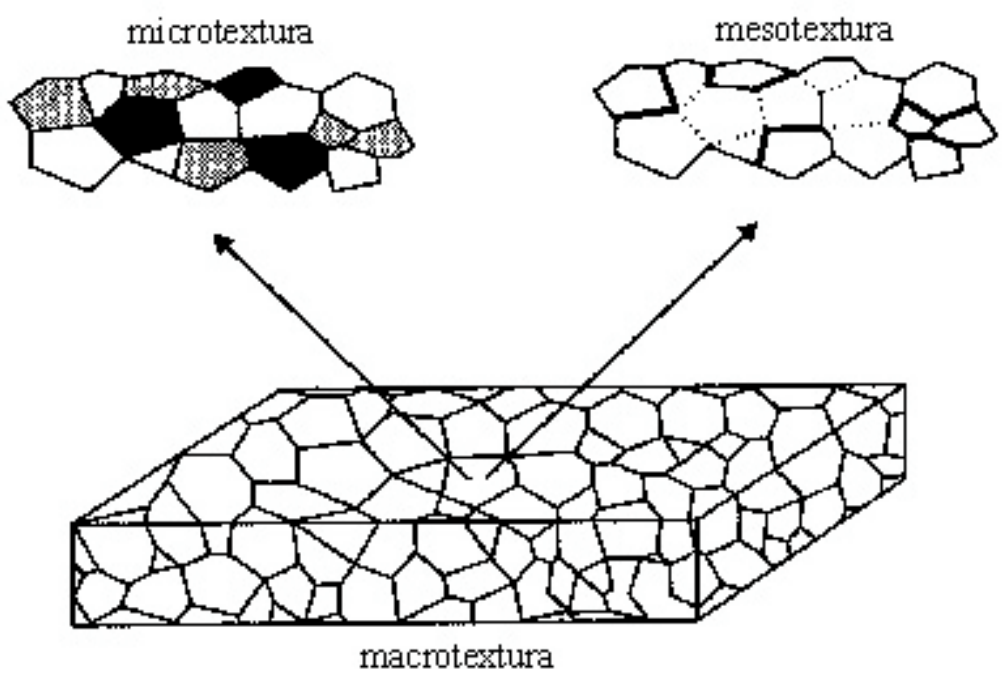

Figura 9 - Desenho esquemático ilustrando a relação entre macrotextura, microtextura e mesotextura. A macrotextura representa a orientação da amostra, a microtextura representa a orientação do grão em uma pequena área, neste caso 15 grãos com 3 orientações diferentes e a mesotextura onde, por exemplo, 3 tipos contornos são indicados [Godec 2000; Randle, 1992].

A maioria das técnicas usada para a análise de textura é fundamentada na difração de ondas pela rede cristalina. Segundo o tipo de radiação usada, raios X, elétrons ou nêutrons, as técnicas podem ser classificadas em relação ao tipo de medida, de macrotextura ou de microtextura. A Figura 10 apresenta um esquema das técnicas para determinação da textura por difração [Randle, 2000]. 

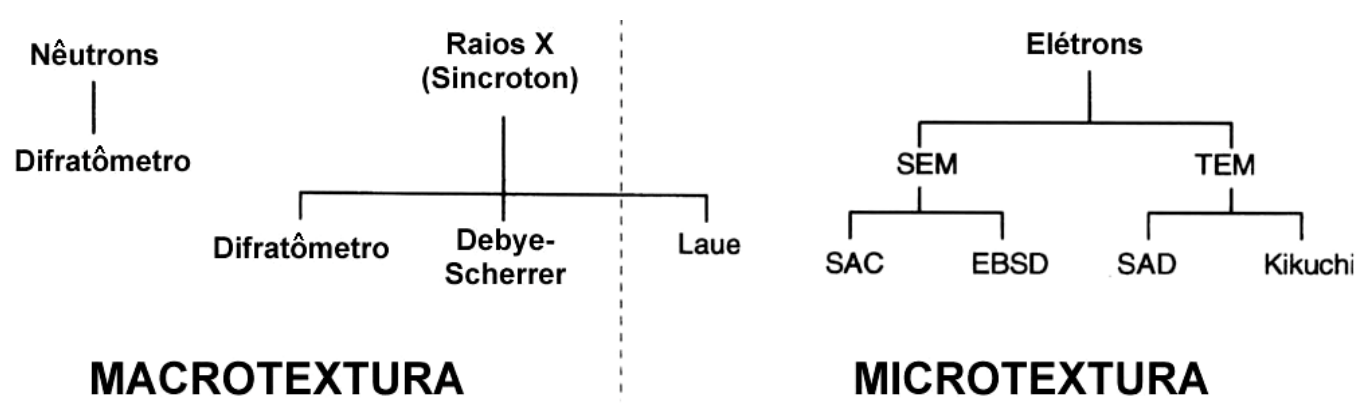

Figura 10 - Categorização das principais técnicas para determinação da textura de acordo com a técnica de difração usada [Randle, 2000].

\subsubsection{Análise da macrotextura}

Para a análise de macrotextura utilizou-se no presente trabalho a técnica difração de raios X. Por meio desta técnica é possível comparar a intensidade da difração de uma amostra com textura forte com a intensidade de uma amostra de orientação aleatória. A textura determinada pela intensidade de difração é referida aos planos cristalinos paralelos, de um só plano da amostra. Para uma investigação mais profunda da textura é preciso usar um goniômetro especial para medidas de textura e a técnica de figuras de pólo.

A análise utilizando o difratômetro de raios $\mathrm{X}$ apresenta a vantagem de poder analisar áreas grandes (aproximadamente $2 \mathrm{~cm}^{2}$ ). Outro aspecto importante é a profundidade de penetração dos raios $\mathrm{X}$ que é muito maior, comparando-se com a profundidade de difração dos elétrons retroespalhados (Tabela 5). Na Tabela 5 são apresentados valores de profundidade de penetração dos raios $X$ para $2 \theta=38,47^{\circ}$ com radiação de cobre e de molibdênio. Os valores apresentados na Tabela 5 foram calculados e comparados com a literatura que aparecem como referência. 
Tabela 5. Comparação de profundidade de penetração.

\begin{tabular}{|c|c|c|c|}
\hline Tipo de radiação & $\begin{array}{c}\mathrm{Cu} \mathrm{k \alpha} \\
{[\text { Kocks et al, }} \\
1998]\end{array}$ & $\begin{array}{c}\text { Mo ka } \\
\text { [Kocks et al, } \\
1998]\end{array}$ & $\begin{array}{c}\text { Elétrons } \\
\text { retroespalhados } \\
\text { [Wei, 2002] }\end{array}$ \\
\hline $\begin{array}{c}\text { Profundidade de } \\
\text { penetração no alumínio } \\
\text { para } 2 \theta=38,47^{\circ}\end{array}$ & $\begin{array}{c}28 \mu \mathrm{m} \\
(\mathrm{G}=90 \%) \\
9 \mu \mathrm{m} \\
(\mathrm{G}=50 \%)\end{array}$ & $\begin{array}{c}279 \mu \mathrm{m} \\
(\mathrm{G}=90 \%) \\
84 \mu \mathrm{m} \\
(\mathrm{G}=50 \%)\end{array}$ & $20 \mathrm{~nm}$ \\
\hline
\end{tabular}

onde $\mathrm{G}=$ é a $\%$ da total intensidade difratada.

A medida de macrotextura por difração de raios X em um material de parâmetro de rede conhecido envolve o uso de um feixe monocromático de radiação com um determinado comprimento de onda, com o ângulo de Bragg fixado para uma família de planos $\{h k 1\}$ escolhida. A amostra policristalina é rotacionada em um goniômetro de textura em ângulos definidos e haverá difração quando os grãos orientados tiverem seus planos $\{\mathrm{hkl}\}$ coincidentes com a condição de Bragg e assim a intensidade de difração é medida [Randle, 2000]. Com esta rotação faz-se com que todos os possíveis planos da rede coincidam com as condições de reflexão e a intensidade refletida é registrada em função destes ângulos de rotação.

Os dois métodos utilizados para medir textura são transmissão e reflexão. O método de reflexão, utilizado no presente trabalho, não exige amostras finas. $\mathrm{Na}$ geometria de reflexão (Figura 11), a amostra é posicionada em um porta-amostra com a direção normal paralela ao eixo de rotação $\phi$, o que permite uma rotação (ângulo $\beta$ ) em seu próprio plano ao redor do eixo normal $\phi$, tal que o ângulo $\phi$ correspondente ao ângulo $\beta$ de um pólo na figura de pólo. Após uma rotação completa de $\phi$, a amostra é inclinada ao redor do eixo $\chi$. O ângulo $\chi$ e o ângulo $\alpha$ da figura de pólo estão relacionados pela equação $\alpha=90-\chi$. O valor limite de $\alpha$ é obtido quando o feixe incidente e o refletido são paralelos à superfície da amostra tal que $\alpha_{\max } \leq 90$. Diferentes aspectos usualmente limitam $\alpha_{\max }$ a valores entre 60-80 [Pulgarín, 2003]. 


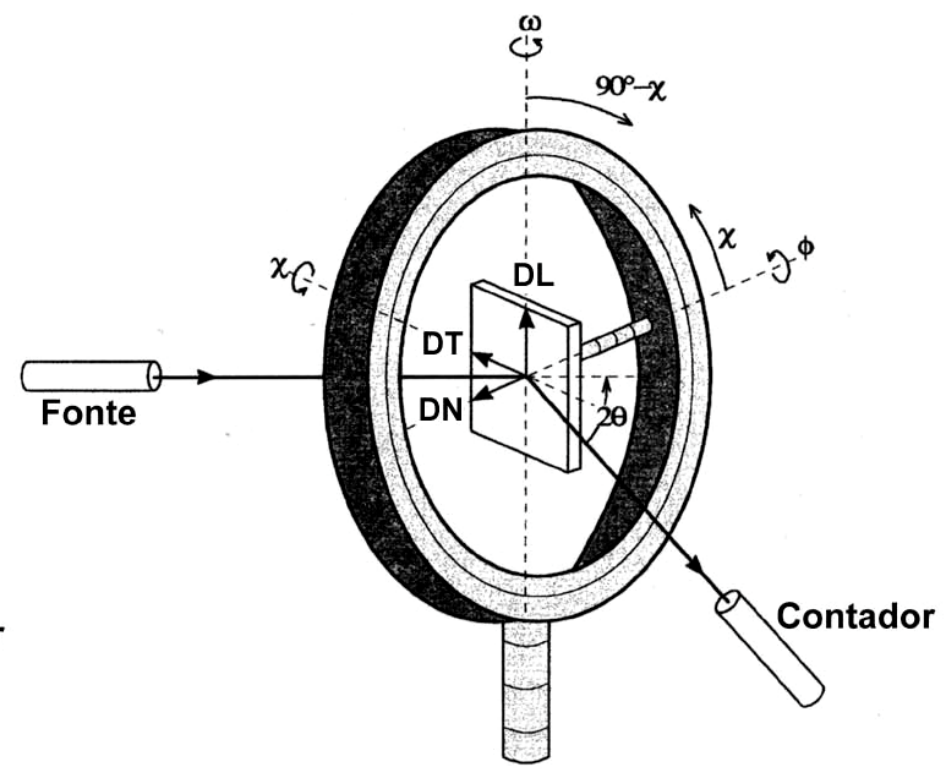

Figura 11 - Goniômetro de textura de geometria de reflexão [Randle, 2000].

A representação gráfica dos resultados experimentais é obtida através de figuras de pólos e após processamento matemático pode-se obter uma função distribuição de orientação (FDO).

\subsubsection{Análise da microtextura}

A difração de elétrons retroespalhados, EBSD, é amplamente utilizada na determinação da microtextura e mesotextura, permitindo o estudo de subdivisão de grão e da natureza dos contornos e subcontornos formados durante a deformação plástica. Quando o EBSD é usado para análises microestruturais quantitativas, os parâmetros críticos são a velocidade de aquisição de dados e as resoluções espacial e angular. Estes dependem de alguns fatores incluindo a amostra, o equipamento e o método de operação. O software acoplado ao EBSD controla os dados de aquisição, identifica os padrões de difração e armazena os dados [Humphreys, 1999].

Quando o feixe de elétrons incide em uma amostra sólida, ocorrem vários eventos tais como emissão de elétrons secundários e Auger, retroespalhamento, absorção 
e transmissão de elétrons, emissão de raios X e de luz. Os elétrons retroespalhados têm praticamente a mesma energia dos elétrons do feixe incidente e são provenientes de regiões onde ocorre uma maior profundidade de interação. Os elétrons retroespalhados são os únicos que têm energia suficiente para causar luminescência numa tela de fósforo e efetivamente contribuir na formação da figura de difração. Para a realização de medidas usando-se a técnica EBSD, a preparação da superfície da amostra é crítica, uma vez que as informações de difração são provenientes de uma profundidade de penetração de $20 \mathrm{~nm}$ da camada da superfície [Wei, 2002].

Durante as medidas de EBSD, a amostra é inclinada cerca de $70^{\circ}$ em relação à horizontal, para aumentar a eficiência de difração (formação das linhas de Kikuchi). O feixe incide em uma região selecionada da microestrutura da amostra posicionada no porta-amostra de um microscópio eletrônico de varredura, como mostra Figura 12. Uma tela fosforescente de cerca de $50 \mathrm{~mm}$ de diâmetro é colocada a uma distância de cerca de $40 \mathrm{~mm}$ da amostra e nela incidem os elétrons retroespalhados formando figuras de difração (linhas de Kikuchi). A imagem da tela fosforescente é capturada por uma câmara de televisão especial, sensível a pequenas quantidades de luz, colocada do lado externo em frente a uma janela transparente de vidro de chumbo. $\mathrm{O}$ vidro de chumbo permite a passagem de luz e absorve os raios X. 


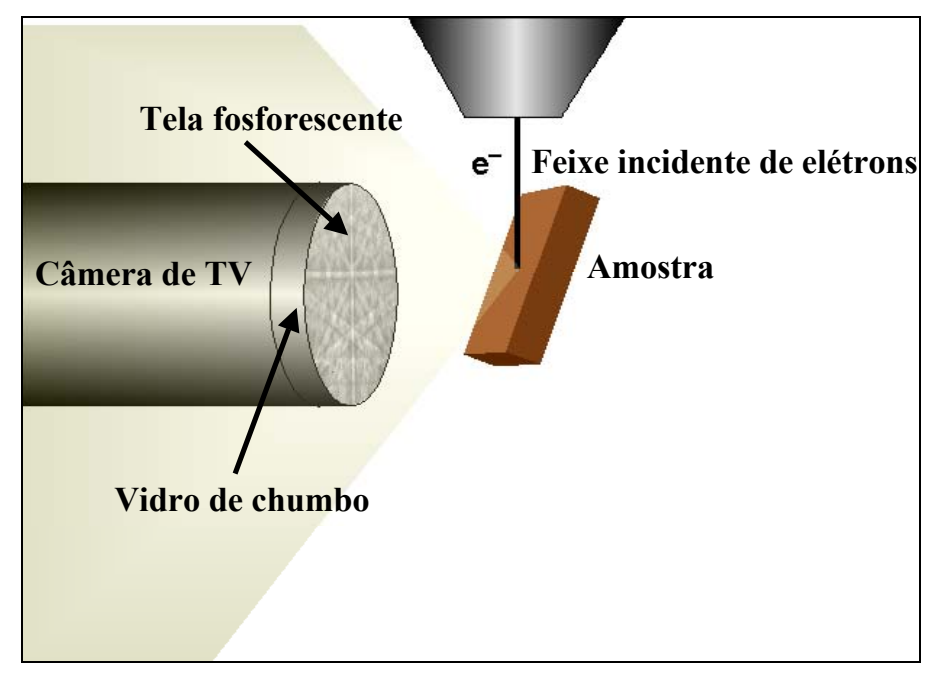

Figura 12 - Desenho esquemático ilustrando o sistema de detecção das figuras de difração de elétrons retroespalhados.

Muitos elétrons do feixe incidente ao interagirem com átomos da amostra sofrem espalhamento e produzem um feixe divergente logo abaixo da superfície. Este feixe divergente de elétrons, por sua vez, incide nos planos cristalinos do cristal em todas as direções e sofre espalhamento elástico. Quando a lei de Bragg é satisfeita são formados cones de difração (Figura 13). Cada conjunto de planos cristalinos forma dois cones de difração: um proveniente do lado superior do plano e outro proveniente do lado inferior. A intersecção dos cones de Kossel com uma tela fosforescente, colocado na frente da amostra, resulta em pares de linhas paralelas. Os elétrons espalhados inelasticamente contribuem para a formação de um fundo (background) difuso.

As linhas de Kikuchi são projeções dos planos cristalinos. A figura de difração é constituída por conjuntos de pares de linhas paralelas sobre um fundo difuso. A distância entre cada par de linhas é inversamente proporcional ao espaçamento interplanar da respectiva família de planos. Em alguns pontos, vários pares de linhas se interceptam, conforme ilustra a Figura 14. Estes pontos de intersecção estão associados com os respectivos eixos das zonas de planos. Indexar a figura de difração significa identificar os planos (pares de linhas) presentes e os eixos das zonas. 


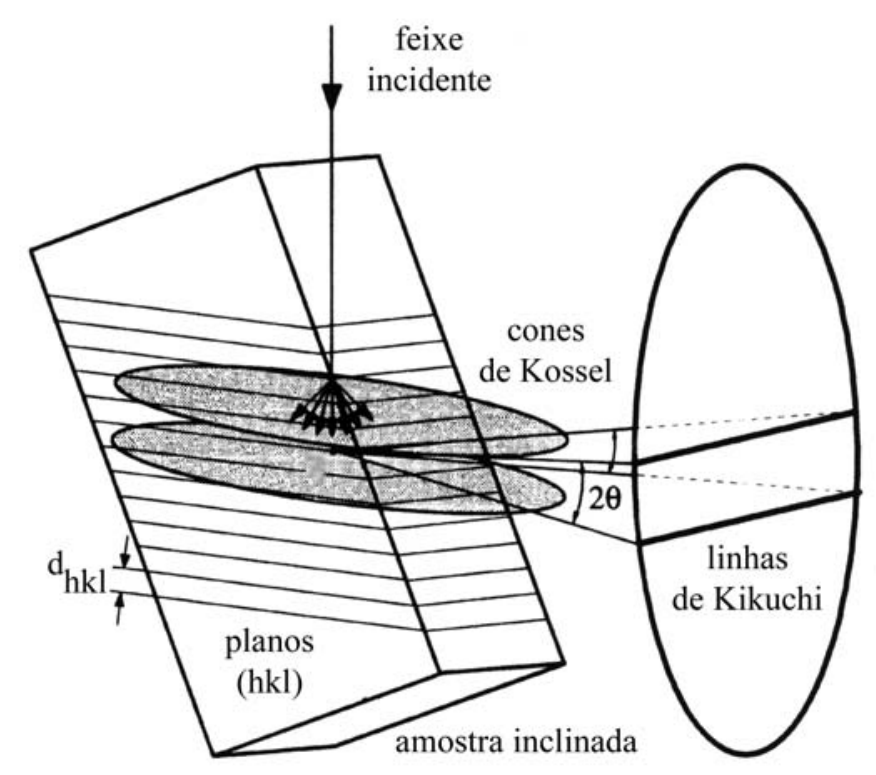

Figura 13 - Desenho ilustrativo da formação dos cones de difração [Randle, 2000].

A imagem capturada é processada e tem inicialmente seu contraste melhorado por meio da subtração do background e é em seguida digitalizada e indexada automaticamente com auxílio de um software adequado. A identificação via computador das linhas de Kikuchi e a indexação da figura de difração exigem o conhecimento prévio da estrutura cristalina que está sendo analisada. O microcomputador comanda o movimento do feixe de elétrons, processa as imagens, realiza a indexação das figuras de difração e calcula os índices e parâmetros desejados [Dingley, 1997]. 

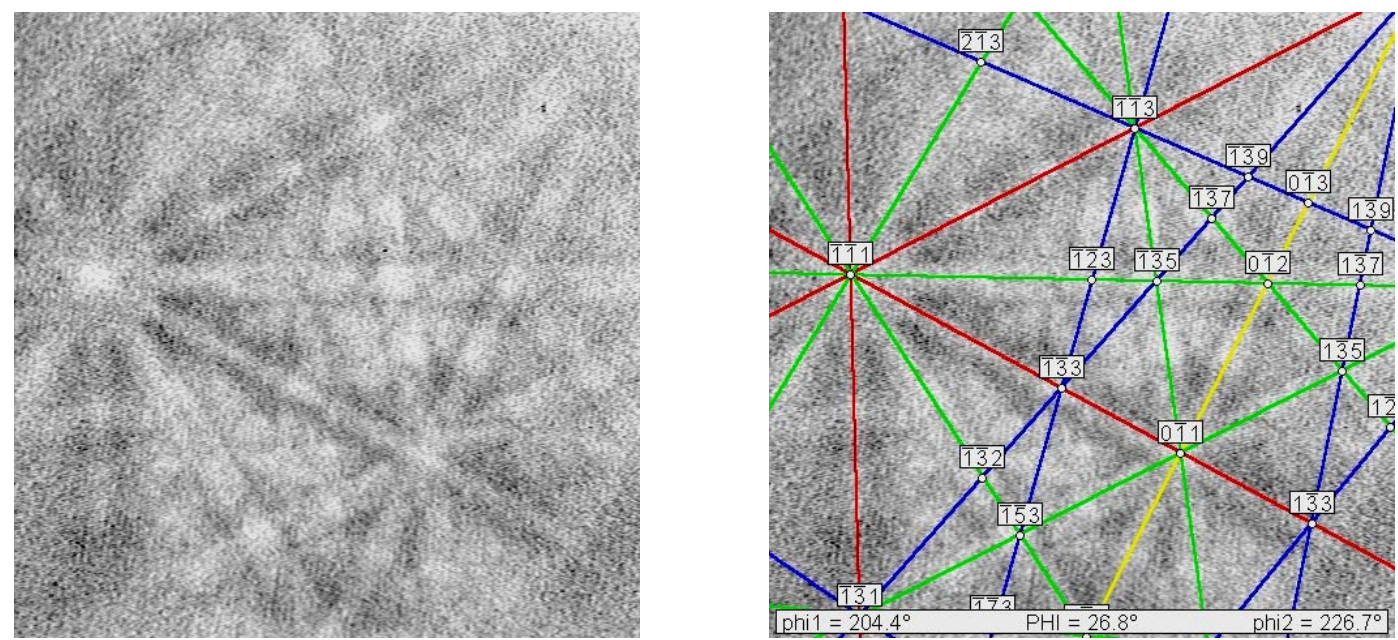

b)

Figura 14 - Linhas de Kikuchi geradas por uma amostra de tântalo laminada até 70\% de redução; a) imagem capturada na tela fosforescente, b) linhas de Kikuchi indexadas pelo software [Martins, 2002].

Para a identificação das linhas de Kikuchi, o software da TSL (TexSEM Laboraties), usado neste trabalho, utiliza a transformada de Hough. A partir da transformada de Hough cada linha de Kikuchi corresponderá a um ponto no espaço de Hough (Figura 15). Será formado para cada banda de Kikuchi (par de linhas de Kikuchi) um ponto claro entre dois pontos escuros, onde o ponto claro corresponde ao interior da banda e os pontos escuros às linhas de Kikuchi [Takanohashi, 2003]. A indexação automática do padrão é realizada a partir das bandas identificadas pela transformada de Hough. 


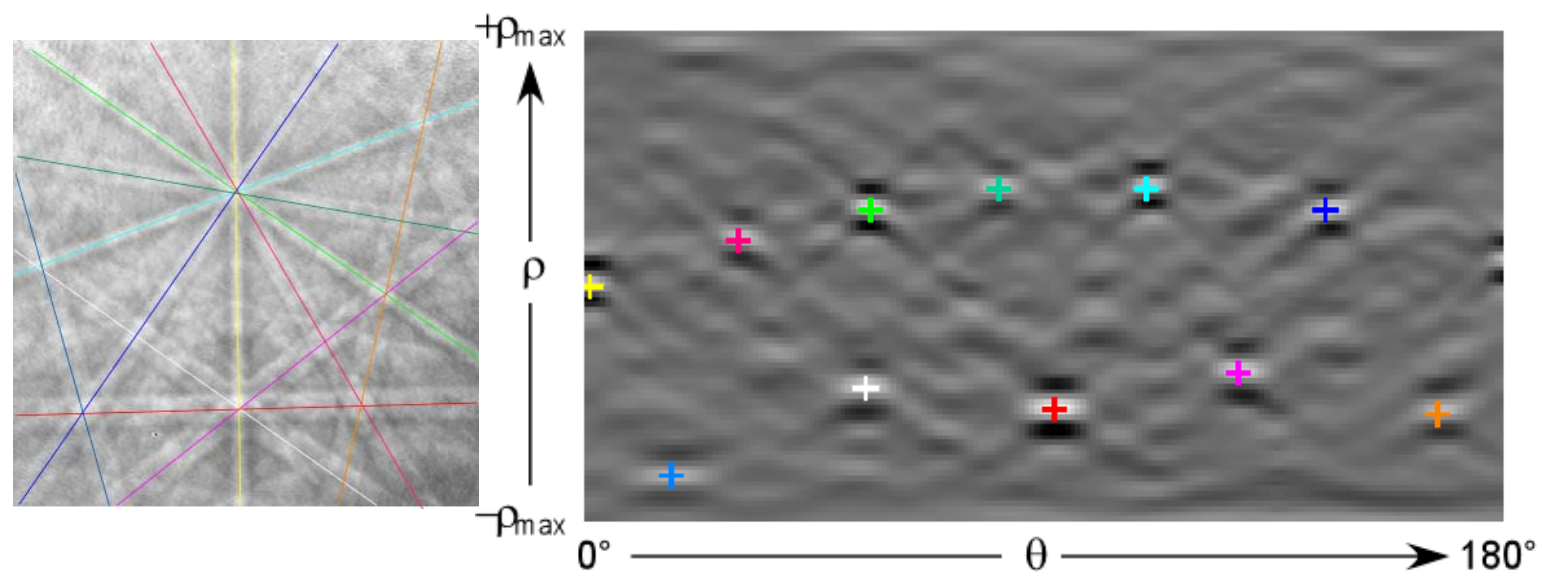

Figura 15 - Identificação do posicionamento das linhas de Kikuchi a partir da identificação dos pontos claros e escuros na imagem do espaço de Hough.

A identificação dos padrões de Kikuchi costuma ser feita através da medição dos ângulos formados pelas linhas retas identificadas, seguida da comparação com uma tabela dos ângulos teóricos correspondentes aos planos difratores do sistema cristalino em questão [Takanohashi, 2003].

\subsubsection{Figura de pólo}

Uma figura de pólo é uma projeção estereográfica que mostra a distribuição de pólos, ou normais aos planos, de um determinado plano (hkl) específico, usando eixos da amostra como eixos de referência. Uma seleção conveniente de eixos de coordenadas 
para uma chapa é a seguinte: direção de laminação (DL), direção transversal à direção de laminação (DT) e direção normal à superfície da chapa (DN) [Bunge, 1982].

Se os grãos têm orientações distribuídas aleatoriamente, os pólos estarão distribuídos uniformemente na projeção. Por outro lado, se os grãos apresentarem orientações preferenciais (textura), os pólos tenderão a se aglomerar ao redor destas orientações, deixando outras áreas da projeção desocupadas.

A figura de pólo inversa é uma representação mais resumida da figura de pólo. Muitas vezes usada para representar orientações em que um eixo é a textura e os outros dois eixos são casualmente distribuídos. A figura de pólo inversa tem uma vantagem para interpretação por sua facilidade de inspeção visual.
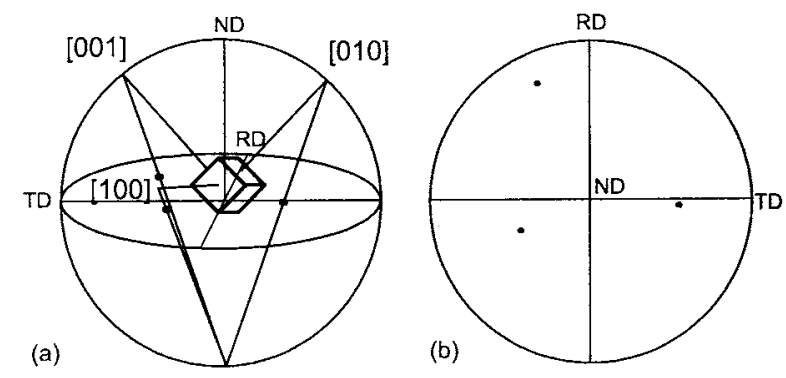

Figura 16 - a) Família de pólos $\{001\}$ em cristal cúbico projetado na esfera de referência de projeção estereográfica; b) Figura de pólo de um cristal [Godec, 2000].

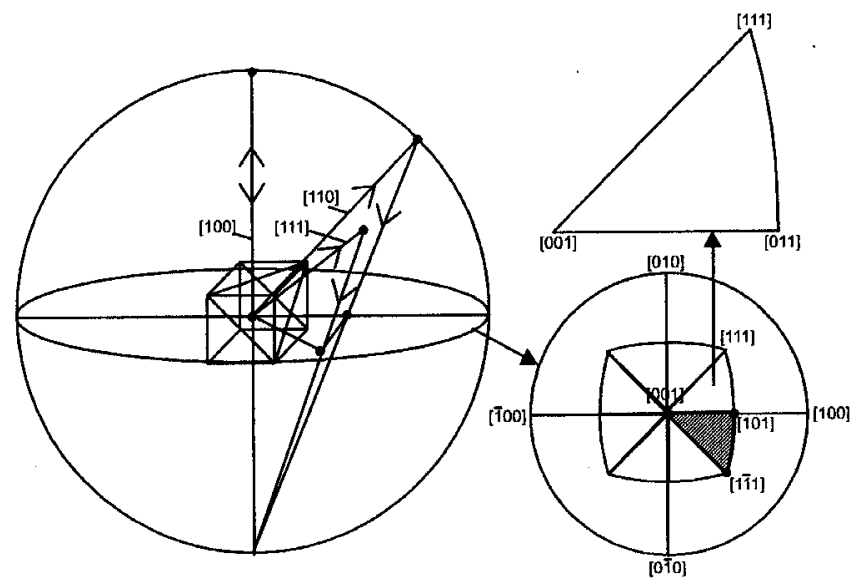


a)

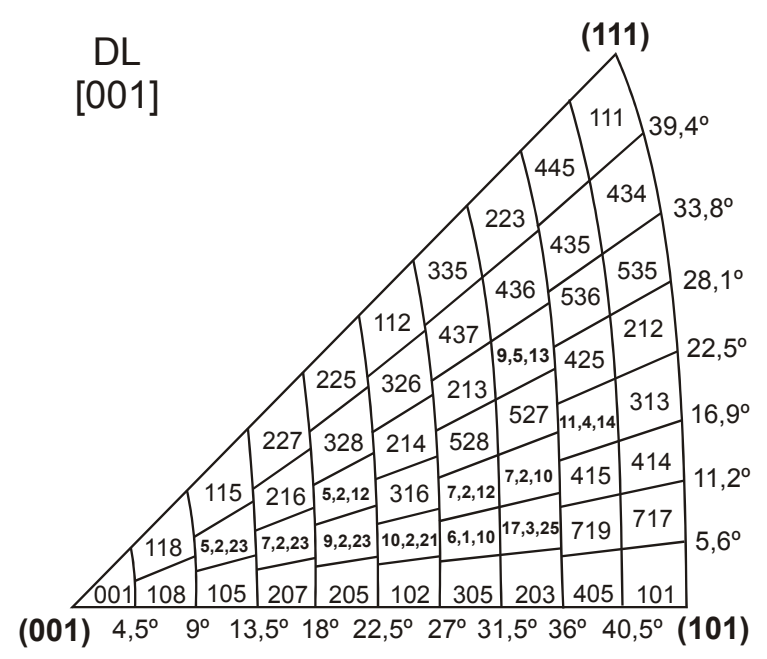

b)

Figura 17 - Figura de pólo inversa: a) projeção estereográfica [Godec, 2000]; b) figura de pólo inversa com identificações de algumas orientações.

\subsubsection{Função distribuição de orientação}

Uma descrição mais completa e quantitativa da textura pode ser obtida com o auxílio da função distribuição de orientação dos grãos (FDO ou ODF - Orientation Distribution Function). Estas funções especificam a freqüência de ocorrência de determinadas orientações em um espaço tridimensional. Este espaço é definido por três ângulos de Euler: $\varphi_{1}, \Phi, \varphi_{2}$. Existem dois sistemas de notação para os ângulos de Euler. Um foi proposto por Bunge e outro por Roe, sendo o mais utilizado o proposto por Bunge [Bunge, 1982]. 

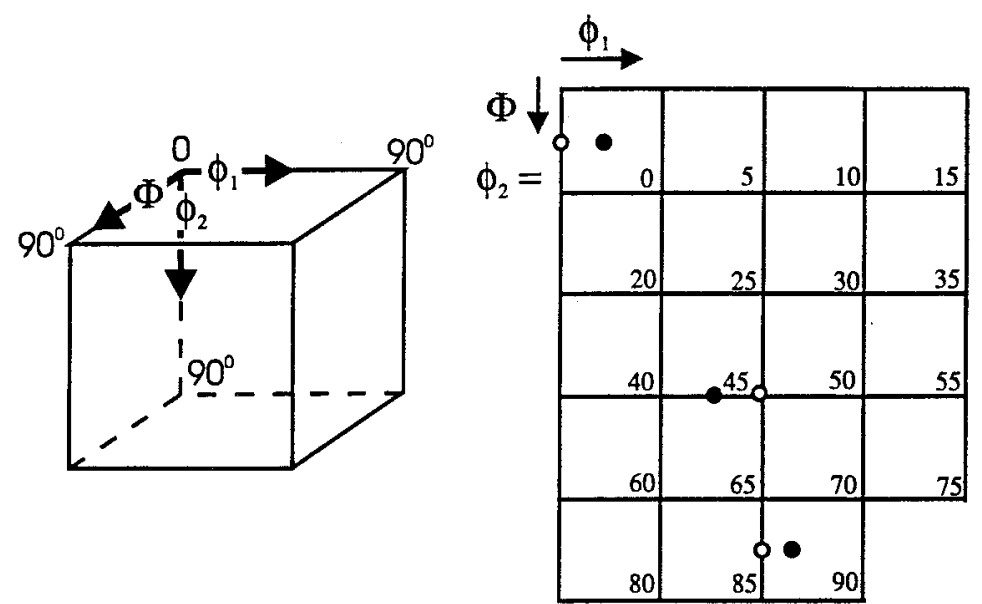

Figura 18 - Seções da FDO mostrando a localização das orientações $\{011\}<100>$ (cujo símbolo na figura é $\circ$ ) e $\{111\}<112>$ (cujo símbolo na figura é •) comumente encontradas em metais com estrutura cúbica.

\subsubsection{Parâmetro $\rho$}

O número de medida de orientação de grão individual necessário para representar adequadamente a textura depende se a textura é forte ou fraca. Enquanto em um monocristal uma medida é suficiente, para texturas fracas milhares de orientações individuais precisam ser medidas. Devido a forte influência da nitidez da textura na exatidão na reprodução em FDO de medidas de orientação de grão individual é necessário desenvolver uma medida quantitativa para um número mínimo de medidas de orientações individuais que são necessárias para representar adequadamente a textura de uma amostra [Randle, 2000].

Pospiech et al [1994] propuseram a análise de convergência do parâmetro estatístico, $\rho$, que representa o desvio do quadrado da média relativa entre duas texturas, para a comparação entre as funções distribuição de orientações obtidas por difração de raios $\mathrm{X}$ e por EBSD. 
$\rho_{0, N}=\frac{\oint\left(F_{0}-F_{N}\right)^{2} d g}{\oint F_{N}^{2} d g} \cdot 100 \%$

onde: $\mathrm{F}_{0}$ é a função distribuição de orientações obtida por difração de raios $\mathrm{X}$ e $\mathrm{F}_{\mathrm{N}}$ é a função distribuição de orientações obtida por EBSD.

Com a análise deste parâmetro pode-se determinar o número mínimo de medidas de orientações individuais, $\mathrm{N}$, necessário para reproduzir apropriadamente a textura correspondente. O número necessário de medidas individuais é obtido quando o valor do parâmetro $\rho_{0, \mathrm{~N}}$ torna-se praticamente constante. Trabalho desenvolvido por Serna [2002] teve como um dos objetivos comparar os aspectos teóricos das técnicas de difração de raios X e difração de elétrons retroespalhados para análise da macrotextura.

\subsubsection{Textura de laminação}

Durante a conformação mecânica, a deformação plástica ocorre principalmente por escorregamento de determinados planos cristalinos. Neste processo, a orientação cristalográfica muda durante a deformação e este fenômeno não é ao acaso, pois o reticulado cristalino sofre rotação, via escorregamento de planos ou por maclação, para orientações mais favoráveis, estabelecendo a chamada textura de deformação [Humphreys, 1995]. A textura final de deformação depende principalmente da orientação inicial dos grãos, da mudança de forma imposta na conformação e da temperatura em que o material foi deformado. Iniciando-se o processo de deformação a partir de um metal com orientação aleatória começa-se a notar a presença da textura de deformação quando se atinge intensidade de redução de $30 \%$ ou mais e o processo se completa com elevadas reduções $(90 \%)$. 

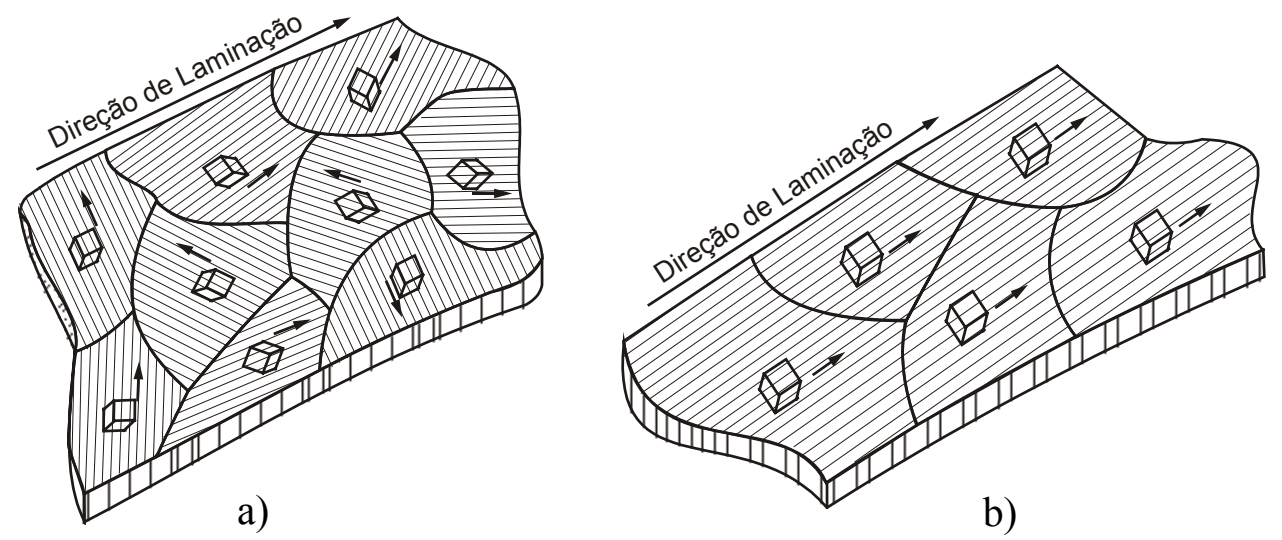

Figura 19 - Desenho esquemático da textura de laminação num material hipotético: a) estado inicial; b) laminado. Observar apenas a direção dos cristais no material hipotético, pois na realidade os grãos, após laminação, encontram-se alongados na direção de laminação e o número de grãos não diminuem conforme está mostrando o desenho esquemático.

As texturas de deformação mais freqüentes no alumínio e suas ligas apresentam [Engler, 1996] predominância dos componentes $\{112\}<11 \overline{1}>$ (conhecida como textura tipo cobre) e $\{110\}<\overline{1} 12>$ (conhecida como textura tipo latão), e eventualmente a presença das componentes $\{011\}<100>$ (conhecida como textura tipo Goss) e $\{123\}$ $<63 \overline{4}>$ (conhecida como textura tipo S).

\subsubsection{Textura de recristalização}

Quando o metal deformado é recozido e sofre recristalização surge uma nova textura. O desenvolvimento da textura de recozimento não termina quando a recristalização primária se completa $\left(\mathrm{V}_{v}^{r}=1\right)$. Ela muda pouco durante o crescimento normal de grão, mas pode mudar fortemente durante o crescimento anormal de grão [Humphreys, 1995]. Embora tenha sido dada muita atenção à relação entre as texturas de deformação e de recristalização, há grande evidência que a orientação do material antes da deformação tenha papel significante na determinação da textura de recristalização. 
Há pelo menos três tipos de textura de recristalização conhecidos: componentes da textura de deformação podem ser conservadas, em outros casos, a textura pode estar muito fraca ou fortemente aleatória (ao acaso) e, finalmente, uma componente fraca de deformação pode se tornar uma componente dominante na textura de recristalização [Doherty, 1997]. Alumínio comercialmente puro laminado a frio, com altas reduções, contendo alta densidade de constituintes ricos em ferro, resulta em uma textura de recristalização com componentes retidas da textura de deformação, enquanto em alumínio com alta pureza a textura de recristalização resultante é composta por uma "nova" orientação tipo cubo, $\{001\}<100>$ com alta intensidade.

A formação da textura de recristalização baseia-se em dois modelos ou teorias: modelo da nucleação orientada e modelo de crescimento orientado [Raabe, 1994]. Vale ressaltar que em 1924, Wever publica as primeiras figuras de pólo de alumínio e ferro laminados a frio. Em 1931, Burges e Louwerse propõem que a textura de recristalização de monocristais de alumínio era resultado de nucleação orientada ("oriented nucleation theory"). A teoria do crescimento orientado ("oriented growth theory") só ganhou força no início da década de 1950, defendida por Beck e colaboradores [1950]. Estes dois modelos são rivais e têm sido motivo de controvérsias durante décadas. A razão para esta falta de consenso é que provar a evolução da textura de recristalização através do crescimento orientado em metal deformado policristalino é uma tarefa difícil e a idéia de nucleação orientada foi por muitos anos um conceito sem suporte teórico [Hjelen, 1991].

A nucleação orientada baseia-se na idéia de que o desenvolvimento da textura de recristalização surge da nucleação preferencial de novos grãos e cujas orientações são próximas a componente de textura de recristalização final, como por exemplo, a textura cubo freqüentemente encontrada após recristalização de metais com estrutura CFC laminados [Doherty, 1985]. Com isso, a nucleação orientada requer que a freqüência da nucleação de grão de uma orientação em especial como a componente do tipo cubo, $\alpha_{c}$, seja maior que a freqüência para nucleação randômica, $\alpha_{r}$ :

$\alpha=\alpha_{\mathrm{c}} / \alpha_{\mathrm{r}} \gg 1$

O crescimento orientado baseia-se na idéia de que o desenvolvimento da textura de recristalização vem da velocidade de crescimento das regiões recristalizadas com 
determinada componente especial. Por exemplo, os grãos com componente cubo, $\mathrm{d}_{\mathrm{c}}$, crescem mais rapidamente que os outros. O crescimento orientado requer que grãos com uma orientação especial cresçam mais rápido que grãos com outras orientações resultando em volumes maiores de grãos com determinadas orientações do que de grãos orientados ao acaso, $\mathrm{d}_{\mathrm{r}}$ [Doherty, 1997]:

$\beta=\mathrm{d}_{\mathrm{c}} / \mathrm{d}_{\mathrm{r}} \gg 1$

Por meio destas fórmulas pode-se analisar a importância relativa de cada mecanismo nucleação orientada ou crescimento seletivo. Portanto, após determinação para um caso em particular dos valores de $\alpha$ e $\beta$, um subseqüente estudo pode direcionar a questão ao mecanismo envolvido naquele caso.

Juul Jensen [Doherty et al, 1998] sugere um novo mecanismo para a alta taxa de crescimento para grãos próximos a orientação cubo. O modelo é denominado orientation pinning, onde o grão recristalizado tem seu crescimento inibido pelo contato com regiões da microestrutura deformada de orientação cristalográfica similar. A interface entre o novo grão e a região da matriz deformada, tendo similar orientação, apresentará contorno de baixo ângulo, conhecido por ter baixa mobilidade.

\subsection{Difração de elétrons}

Padrões de difração de elétrons são obtidos em microscopia eletrônica de transmissão e usados para se obter informações como a identificação de fases e suas relações de orientação com a matriz.

Para uma determinada direção do feixe de elétrons incidentes o número de feixes difratados no padrão de difração é determinado usando-se a esfera de Ewald e a rede recíproca. $\mathrm{O}$ feixe difratado que aparece no padrão de difração ocorre quando a esfera de Ewald corta pontos da rede recíproca (como mostra a Figura 20) especificando os índices dos planos de reflexão, o ângulo de Bragg e a direção do feixe difratado. Como a esfera de Ewald possui raio $1 / \lambda$, pode-se considerar que seja uma seção plana, pois $\lambda$ é bastante pequeno e, deste modo, $1 / \lambda$ é bastante grande. Portanto, o diagrama de difração 
corresponde a uma seção plana perpendicular ao feixe incidente. Todo "spot" de difração representa um ponto do espaço recíproco, que por sua vez corresponde a um plano (hkl). Um ponto $(\mathrm{hkl})$ da rede recíproca é obtido traçando-se pela origem do espaço real uma perpendicular ao plano (hkl). O módulo do vetor da rede recíproca referente ao (hkl) é o inverso do espaçamento d entre os planos (hkl) do espaço real. A seguir são demonstrados como os feixes difratados geram o diagrama de difração.

O processo de difração pode ser visualizado como reflexão de planos cristalinos (hkl) com espaçamento $\mathrm{d}_{(\mathrm{hkl})}$. Os feixes difratados são correspondentes à reflexão para um determinado ângulo $\theta$ (ângulo entre o feixe incidente e o plano cristalino) que satisfaz a equação $n \lambda=2 \mathrm{~d} \operatorname{sen} \theta$ (lei de Bragg), como mostra a Figura 21. A Figura 21 mostra a concordância com a lei de Bragg, feixes em fase (interferência constrututiva) geram feixes de reflexão (feixe difratado) obedecendo a lei de Bragg. Alguns elétrons que não sofrem reflexão atravessam o cristal formando o feixe transmitido que forma um ângulo de $2 \theta$ com o feixe de elétrons difratado.

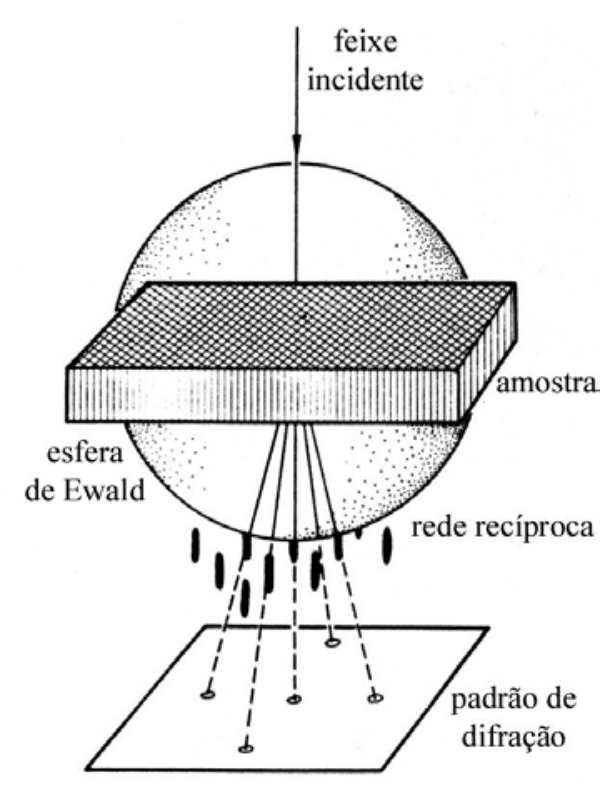

Figura 20 - A amostra, feixe transmitido, feixe difratado e o padrão de difração. A sobreposição da construção da esfera de Ewald no espaço recíproco descreve o padrão de difração. 
Uma descrição matemática da difração foi primeiramente apresentada por Laue em 1912 e suas equações são utilizadas até hoje. A difração pode ser considerada em termos de espalhamento de elétrons por átomos individuais. A Figura 22 mostra os átomos $\mathrm{O}$ e $\mathrm{L}$ e a posição relativa de $\mathrm{L}$ em relação a origem $\mathrm{O}$ é descrita pelo vetor $r$. $\mathrm{O}$ feixe incidente e o espalhado são descritos por $p_{0}$ e $p$, respectivamente. Descrevendo a distância PO em notação vetorial como $r \cdot p_{0}$ e OD como $r \cdot p$, tem-se $\mathrm{POD}=r \cdot\left(p-p_{0}\right)$. Definindo o vetor $P=p-p_{0}$, tem-se:

$\mathrm{POD}=r . P=n \lambda$

a)

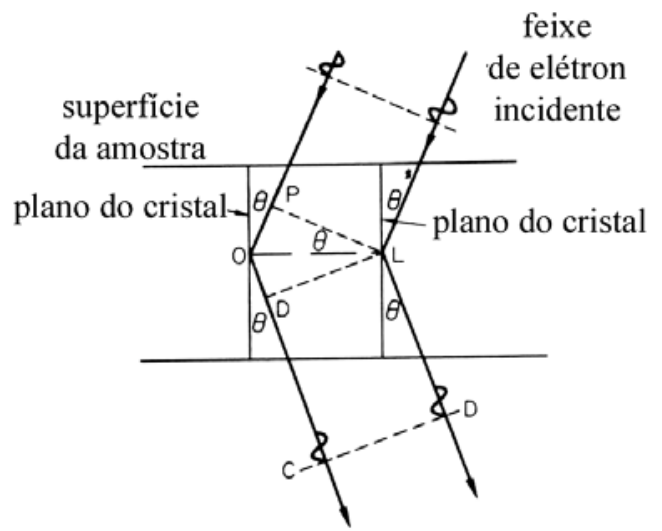

feixe

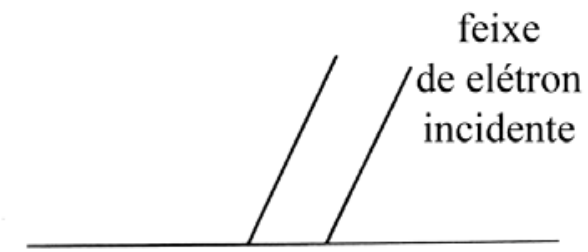

b)

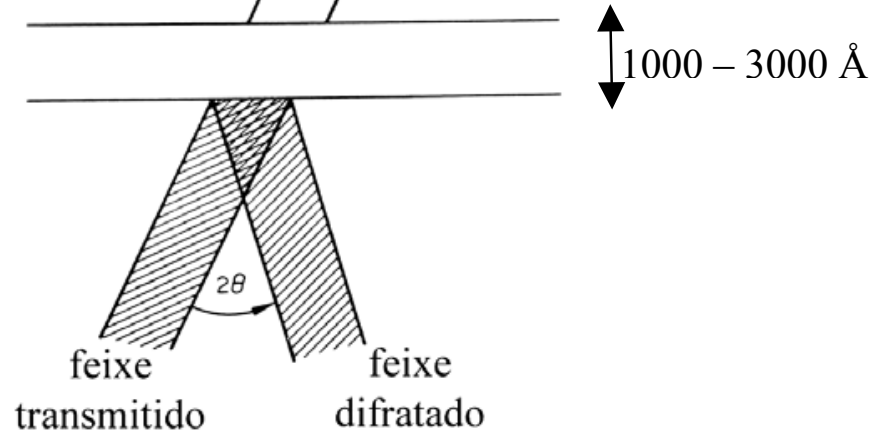

Figura 21 - a) Reflexão no ângulo $\theta$ de Bragg de planos de cristais em amostra finas em microscópio eletrônico de transmissão; b) A relação entre feixes incidentes, transmitidos e difratados [Edington, 1976]. 
A relação entre $p, p_{0}$ e $P$ pode ser descrito como triângulo de vetores mostrado na Figura 22 b, onde os vetores são normalizados dividindo-os pelo comprimento de onda $\lambda$. É mais conveniente descrever a posição relativa de cada átomo pelos eixos cristalinos $x$, $y$, e $z$ do que utilizar o vetor $r$. Para isso é necessário decompor o vetor r.P em componentes P.a, P.b e P.c, onde $a, b$ e $c$ são as distâncias dos átomos no eixo cristalino. Cada componente decomposta pode ser representada pelas equações abaixo que são conhecidas como as condições de Laue:

$$
\begin{aligned}
& \text { P.a }=h . \lambda \\
& \text { P.b }=k \lambda \\
& \text { P.c }=\text { l. } \lambda
\end{aligned}
$$

Para se entender melhor a interpretação do padrão de difração é preciso ainda explicitar os conceitos de rede recíproca e a esfera de Ewald.

A rede recíproca é derivada diretamente das condições de Laue descrita nas equações acima:

$P / \lambda=h \cdot a^{*}+k \cdot b^{*}+l \cdot c^{*}$

onde $a^{*}, b^{*}$ e $c^{*}$ são vetores definidos como $a . a^{*}=b . b^{*}=c . c^{*}=1$ e $a^{*} . b=b^{*} . a$, etc. $=$ 0 . Estas condições têm explicações físicas, na relação $a^{*} \cdot b=a^{*} \cdot c=0$ significa que $a^{*}$ é perpendicular a $b$ e a $c$ e a relação $a . a^{*}=1$ define a magnitude do vetor como $\left|a^{*}\right|=1 /|a|$ que é a origem do termo rede recíproca.

A rede recíproca tem duas propriedades interessantes [Edington, 1976]:

- $\quad \mathrm{O}$ vetor $g_{(\mathrm{hkl})}$ para o ponto $(\mathrm{hkl})$ da rede recíproca é normal ao plano (hkl) da rede cristalina;

- $\quad$ O módulo de $g_{(h k l)}$ é $1 / d_{(h k l)}$ onde $d_{(h k l)}$ é o espaço interplanar da família de planos (hkl). 
A rede recíproca pode ser definida como um arranjo de pontos, onde cada ponto corresponde a um plano (hkl) particular e é definido por um vetor.

A distância LO e LG mostrados na Figura 23 é igual a $1 / \lambda$ que representa uma pequena parte de uma esfera (pois a rede recíproca é tridimensional) de raio $1 / \lambda$ no espaço recíproco, conhecido esfera de Ewald.

a)

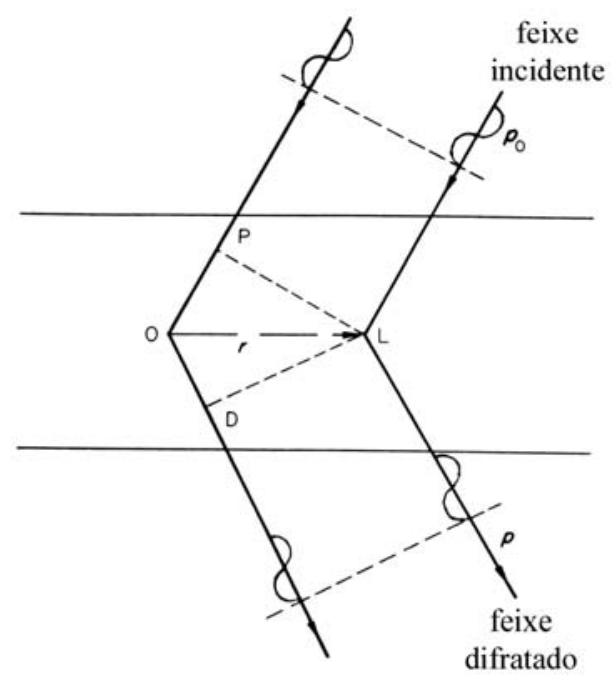

b)

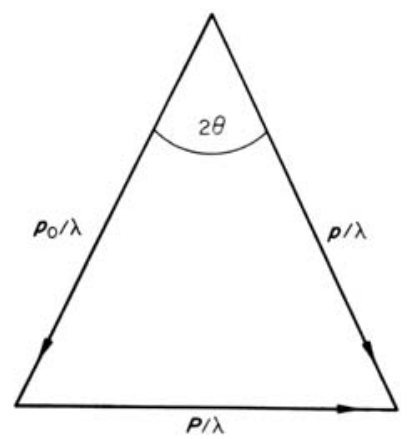

Figura 22 - a) Feixe difratado por átomos situados na posição $\mathrm{O}$ e L na amostra; b) Diagrama vetorial descrevendo o processo de difração [Edington, 1976]. 


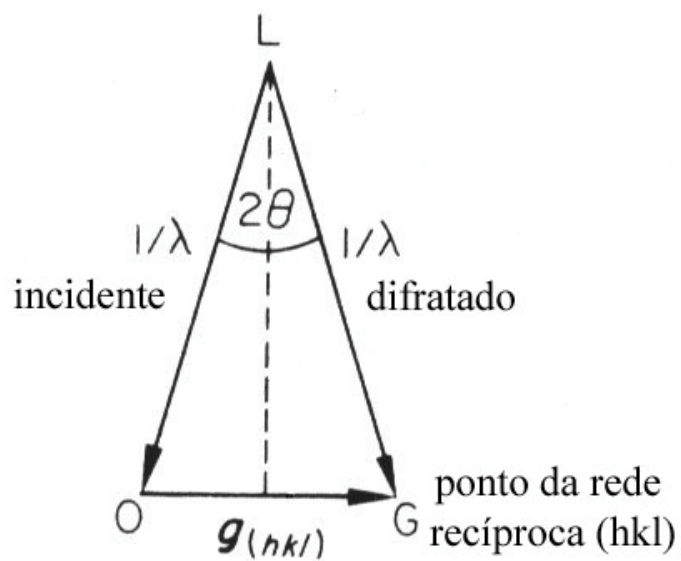

Figura 23 - Diagrama vetorial no espaço recíproco mostrando a reflexão do plano cristalino (hkl). 


\section{MATERIAIS E MÉTODOS}

No capítulo 2 foram apresentadas propriedades e características da liga de alumínio da série 3003. A seguir encontra-se uma breve descrição dos materiais obtidos pelos dois processos analisados. Encontra-se também uma Tabela contendo as composições químicas (Tabela 6). Estes dados serão discutidos no capítulo 4.

\subsection{Material}

Foram utilizadas duas chapas da liga 3003. Uma das chapas tinha $6 \mathrm{~mm}$ de espessura e foi produzida, em 1975, por lingotamento semicontínuo de placas com 250 $\mathrm{mm}$ de espessura, seguido de homogeneização e laminação a quente. A outra chapa tinha 7,4 mm de espessura, foi produzida por fundição contínua de chapas ("caster") e encontrava-se no estado bruto de fundição. A Tabela 6 apresenta as composições químicas das duas chapas em três posições diferentes: superfície, 1/4 da espessura abaixo da superfície e no centro da chapa. Essas determinações foram feitas utilizando-se um espectrômetro de emissão óptica, marca ARL modelo 3460, instalado na CBA Companhia Brasileira de Alumínio/SP. Para análise ao longo da espessura, as chapas foram desbastadas através de uma retífica até a espessura desejada. As análises ao longo da espessura foram feitas apenas para caracterização inicial (microestrutura e textura) das chapas provenientes dos dois processos. 
Tabela 6. Composição química (em \% em peso) da chapa laminada a quente e da chapa produzida por fundição contínua de chapas (“caster”) em três posições diferentes: superfície, $1 / 4$ da espessura abaixo da superfície e no centro da chapa.

\begin{tabular}{|c|c|c|c|c|c|c|c|c|c|c|c|c|}
\hline Processo: posição & $\mathbf{S i}$ & $\mathbf{F e}$ & $\mathbf{M g}$ & $\mathbf{M n}$ & $\mathbf{C u}$ & $\mathbf{C r}$ & $\mathbf{N i}$ & $\mathbf{T i}$ & $\mathbf{V}$ & $\mathbf{Z n}$ & $\mathbf{G a}$ & $\mathbf{B}$ \\
\hline $\begin{array}{c}\text { Chapa Laminada: } \\
\text { superfície }\end{array}$ & 0,197 & 0,575 & 0,02 & 0,998 & 0,132 & 0,007 & 0,003 & 0,015 & 0,006 & 0,011 & 0,012 & 0,001 \\
\hline $\begin{array}{c}\text { Chapa Laminada: } \\
\text { 1/4 }\end{array}$ & 0,198 & 0,577 & 0,02 & 1,004 & 0,132 & 0,007 & 0,003 & 0,015 & 0,006 & 0,011 & 0,012 & 0,001 \\
\hline $\begin{array}{c}\text { Chapa Laminada: } \\
\text { centro }\end{array}$ & 0,2 & 0,581 & 0,02 & 1,002 & 0,133 & 0,007 & 0,003 & 0,016 & 0,006 & 0,011 & 0,012 & 0,002 \\
\hline Caster: superfície & 0,084 & 0,631 & 0,001 & 1,224 & 0,236 & 0,004 & 0,002 & 0,024 & 0,008 & 0,009 & 0,012 & 0,003 \\
\hline Caster: 1/4 & 0,083 & 0,630 & 0,001 & 1,223 & 0,236 & 0,004 & 0,003 & 0,029 & 0,008 & 0,009 & 0,013 & 0,004 \\
\hline Caster: centro & 0,084 & 0,631 & 0,001 & 1,221 & 0,236 & 0,004 & 0,002 & 0,028 & 0,008 & 0,009 & 0,013 & 0,004 \\
\hline
\end{tabular}

\subsection{Métodos}

É importante convencionar que amostras provenientes da chapa com $6 \mathrm{~mm}$ de espessura, produzida por lingotamento semicontínuo de placas com $250 \mathrm{~mm}$ de espessura, seguido de homogeneização e laminação a quente será designada ao longo deste trabalho apenas de amostra laminada a quente. Amostras provenientes de chapa com 7,4 mm de espessura, produzida por lingotamento contínuo (“caster”) será designada ao longo deste trabalho de amostra caster. Pela facilidade de obtenção de amostras provenientes do processo roll caster foi possível realizar diversos experimentos com estas amostras, cujos resultados serão apresentados nos diversos itens do capítulo 4. Não foi possível reproduzir os mesmos experimentos para a amostra laminada a quente (produzida em 1975), pois a quantidade de material disponível foi limitante. Outra informação relevante é que o estudo ao longo da espessura foi sempre realizado, desbastando-se amostras até espessura desejada (1/4 e 1/2). Estas amostras foram utilizadas para a comparação dos dois processos avaliados no presente trabalho e são apresentados nos capítulos de caracterização inicial e caracterização de textura, 4.1 e 4.2. 


\subsubsection{Microscopia óptica}

Para a análise por microscopia óptica, as amostras foram lixadas utilizando-se lixas de carboneto de silício de 220,320, 400, 600 e 1000, e posterior polimento com pasta de diamante com as granulometrias de $6,3 \mathrm{e} 1 \mu \mathrm{m}$. O polimento final foi feito com solução OP-S (sílica coloidal). Após o polimento, as amostras foram anodizadas para se revelar a estrutura dos grãos sob luz polarizada. A anodização foi feita em um aparelho Polectrol da Struers, com as seguintes condições:

Cátodo: aço inoxidável.

Eletrólito: solução 2\% de ácido fluobórico.

Voltagem: $20 \mathrm{~V}$.

Tempo: 2 min.

Os microscópios utilizados foram o Neophot 30 Carl Zeiss e o Ultraphot também da Carl Zeiss, instalados no Departamento de Engenharia Metalúrgica e de Materiais da EPUSP.

\subsubsection{Microscopia eletrônica de varredura}

Para a análise por microscopia eletrônica de varredura, as amostras foram lixadas utilizando-se lixas de carboneto de silício de 220,320,400, 600 e 1000, e posterior polimento com pasta de diamante com as granulometrias de 6,3 e $1 \mu \mathrm{m}$. O polimento final foi feita com solução OP-S (sílica coloidal). Para análise por EBSD, as amostras foram polidas eletroliticamente. $\mathrm{O}$ polimento eletrolítico final foi realizado com o eletrólito: $700 \mathrm{~mL}$ de álcool etílico; $120 \mathrm{~mL}$ de água destilada; $100 \mathrm{~mL}$ de butil glicol e $68 \mathrm{~mL}$ de ácido perclórico. O polimento eletrolítico foi feito em um aparelho Polectrol da Struers, com $40 \mathrm{~V}$ por 10 segundos. As análises por microscopia eletrônica de varredura foram realizadas em aparelho modelo XL-30 da Philips, instalado no Departamento de Engenharia Metalúrgica e de Materiais da EPUSP. Este equipamento dispõe dos detectores de elétrons secundários e retroespalhados, analisador de raios $\mathrm{x}$ por dispersão de energia e análise por difração de elétrons retroespalhados. As medidas 
de microtextura e mesotextura foram feitas neste mesmo microscópio, com auxílio do software OIM 3.3 da TSL.

\subsubsection{Microscopia eletrônica de transmissão}

As amostras para observação por microscopia eletrônica de transmissão foram desbastadas por eletroerosão até $0,5 \mathrm{~mm}$ de espessura, e depois foram estampados discos de $3 \mathrm{~mm}$ de diâmetro. O polimento eletrolítico final foi realizado no eletrólito: $700 \mathrm{~mL}$ de álcool etílico; $120 \mathrm{~mL}$ de água destilada; $100 \mathrm{~mL}$ de butil glicol e $68 \mathrm{~mL}$ de ácido perclórico. As observações foram feitas em um microscópio eletrônico de transmissão da marca Jeol, com 200 kV, modelo JEM 200C (resolução 50Å), instalado no Centro de Caracterização e Tecnologia dos Materiais - IPEN/SP.

\subsubsection{Extração de precipitados}

Com o objetivo de caracterizar os precipitados da liga estudada, utilizou-se a técnica de extração de precipitados. Após extração os precipitados são separados das soluções (e lavados) por filtragem sob vácuo, usando filtros de teflon (PTFE; politetraflúoretileno). Para identificação dos precipitados foi utilizada a técnica difratometria de raios $\mathrm{x}$ (com tubo de cobre), em um equipamento Philips modelo MPD 1880, instalado no Departamento de Engenharia de Minas da EPUSP.

Foram feitas duas varreduras na mesma amostra: a primeira, $\operatorname{com} 2 \theta$ inicial $=15^{\circ}$ e $2 \theta$ final $=80^{\circ}$, passo de $0,02^{\circ}$ e tempo de exposição de $1 \mathrm{~s}$; a segunda varredura, com $2 \theta$ inicial $=36^{\circ}$ e $2 \theta$ final $=46^{\circ}$, passo de $0,02^{\circ}$ e tempo de exposição de 10 segundos. A segunda varredura foi feita para facilitar a identificação dos picos das fases presentes, em região de superposição de picos. 


\subsubsection{Método da dissolução química}

Pelo método químico foram utilizados dois tipos de reagentes diferentes:

1. iodo dissolvido em metanol como reagente;

2. fenol como reagente

Na primeira técnica, foi preparada uma solução contendo $10 \mathrm{~g}$ de iodo em $100 \mathrm{~mL}$ de metanol. Em um erlenmeyer adicionou-se a amostra à solução preparada, à temperatura ambiente e sob agitação, durante algumas horas.

Na segunda técnica, foi pesado $120 \mathrm{~g}$ de fenol. Em um erlenmeyer adicionou-se a amostra ao fenol em ebulição, sob agitação, durante 15 min. Após este tempo, adicionou-se $80 \mathrm{~mL}$ de álcool benzílico, bem lentamente. Quando a solução atingiu a temperatura ambiente, centrifugou-se 5 vezes com o álcool benzílico durante $10 \mathrm{~min}$ cada centrifugação, sempre separando o sólido do líquido e mais 2 vezes utilizando-se metanol. Secou-se e pesou-se o resíduo.

\subsubsection{Método da dissolução eletrolítica}

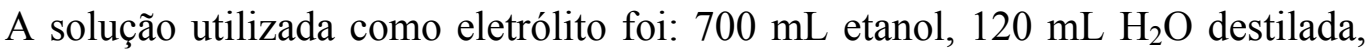
$100 \mathrm{~mL}$ butil glicol e $68 \mathrm{~mL}$ ácido perclórico. O ataque eletrolítico foi feito em um aparelho Polectrol da Struers. Uma placa de aço inoxidável 316L foi utilizada como cátodo e a amostra de liga de alumínio, a ser dissolvida, serviu como ânodo. $\mathrm{O}$ aparelho Polectrol permite que se varie a tensão, com isso, pode-se escolher a voltagem do ataque. Primeiro optou-se por 50 V [Pimenta et al, 1986] o que gerou uma densidade de corrente de $5 \mathrm{~A} / \mathrm{cm}^{2}$ e uma reação muito severa. O ácido perclórico é explosivo a uma temperatura próxima de $30^{\circ} \mathrm{C}$ e para se evitar acidentes, a cuba eletrolítica foi imersa em uma unidade de refrigeração da Quimis, modelo Q-214U, deste modo, a temperatura da solução eletrolítica ficou em torno de $-10^{\circ} \mathrm{C}$. Por esta razão também se deu preferência por se trabalhar com reações menos severas, portanto diminui-se a voltagem para $30 \mathrm{~V}$, o que levou a uma densidade de corrente de $1,25 \mathrm{~A} / \mathrm{cm}^{2}$ e às vezes abaixava-se para 5 $\mathrm{V}\left(0,25 \mathrm{~A} / \mathrm{cm}^{2}\right)$. 
Uma outra solução foi utilizada pelo método eletrolítico: $15 \mathrm{~g}$ de oxina, $60 \mathrm{~g}$ de ácido benzóico, $60 \mathrm{~mL}$ de clorofórmio, $165 \mathrm{~mL}$ de metanol. Utilizou-se voltagem de $50 \mathrm{~V}$ que resultou em uma reação severa, mas com baixa densidade de corrente $(0,05 \mathrm{~A} /$ $\left.\mathrm{cm}^{2}\right)$.

\subsubsection{Difração de raios $X$ para determinação da textura}

Para a preparação das superfícies a serem analisadas fez-se o lixamento utilizando lixas de carboneto de silício de 220,320,400, 600 e 1000, e posterior polimento com pasta de diamante com as granulometrias de 6, 3 e $1 \mu \mathrm{m}$. Para a difração de raios X, a preparação da superfície não é tão problemática como para EBSD, pois a penetração do feixe é da ordem de 10 a $200 \mu \mathrm{m}$, dependendo do material e da radiação utilizada.

Para estudo de textura utilizou-se um difratômetro Rigaku DMAX-2000 com goniômetro de textura horizontal, modelo "multipurpose", radiação $\mathrm{Cu} \mathrm{k} \alpha$, instalado no Centro de Ciência e Tecnologia dos Materiais - IPEN/SP. Figuras de pólos (111), (220), (200) e (311) foram medidas.

\subsubsection{Metalografia quantitativa}

Para medida de fração volumétrica e tamanho de partículas no estado bruto de fundição, as amostras foram lixadas utilizando-se lixas de carboneto de silício até grana 2400 , e posterior polimento com pasta de diamante com granulometrias de 3,1 e $1 / 4 \mu \mathrm{m} \mathrm{e}$ polimento final com solução de sílica coloidal (OP-S Struers). Um leve ataque metalográfico com solução de ácido fluorídrico foi feito com o objetivo de destacar os precipitados. Foram feitas em média 15 medidas para cada amostra. Utilizou-se a técnica de microscopia óptica em campo escuro seguida da determinação da fração volumétrica de precipitados no analisador de imagens KS 300 (software). A técnica empregada permite destacar os precipitados da matriz, facilitando a rotina de determinação da 
fração volumétrica com o equipamento KS 300. Para a amostra laminada a quente utilizou-se o analisador Quantimet acoplado um microscópio ótico Olympus BX60m.

\subsubsection{Laminação}

No presente trabalho utilizaram-se dois laminadores. No primeiro caso, com o intuito de se analisar textura de laminação de amostras provenientes do processo caster, as amostras foram laminadas a frio (com prévio tratamento térmico de homogeneização) em um equipamento industrial na CBA - Companhia Brasileira de Alumínio/SP, até $67 \%$ e $91 \%$ de redução.

No segundo caso, com o intuito de se comparar o efeito da homogeneização antes da laminação a frio, duas placas foram laminadas no laminador duo reversível, instalado no Departamento de Engenharia Metalúrgica e de Materiais da EPUSP. As duas placas antes da laminação possuíam as mesmas dimensões: $200 \mathrm{~mm}$ x 35 mm e 7,4 mm de espessura. Uma placa era bruta de fundição e a outra sofreu prévio tratamento térmico de homogeneização. Amostras foram retiradas das duas placas nas mesmas reduções. Houve pequena diferença no número de passes para se obter a deformação final igual.

Tabela 7. Deformações reais e reduções em área obtidas para as duas placas laminadas.

\begin{tabular}{|c|c|}
\hline Deformação real & Redução em área \\
\hline 0,21 & $20 \%$ \\
\hline 0,41 & $34 \%$ \\
\hline 0,61 & $46 \%$ \\
\hline 0,81 & $55 \%$ \\
\hline 1,17 & $69 \%$ \\
\hline 1,34 & $74 \%$ \\
\hline 1,67 & $81 \%$ \\
\hline 1,94 & $86 \%$ \\
\hline 2,43 & $91 \%$ \\
\hline
\end{tabular}




\subsubsection{Tratamentos térmicos}

No presente trabalho foram utilizados três fornos diferentes. A seguir apresentase detalhadamente cada forno utilizado.

Os tratamentos térmicos para estudo da textura de recristalização de amostras provenientes do processo caster foram realizados em um forno elétrico tubular de $2 \mathrm{kVA}$ de potência construído para temperaturas de até $1300^{\circ} \mathrm{C}$. Este forno foi construído com uma câmara tubular de mulita envolta em resistência solenoidal de Khantal A1. Possuía uma camada isolante de manta refratária sílico - aluminosa de aproximadamente 150 $\mathrm{mm}$ de espessura e revestimento externo de aço inoxidável AISI 304. O tratamento térmico para recristalização foi feito a $400^{\circ}$ por 1 hora. As amostras que sofreram tratamento térmico de recristalização foram resfriadas ao ar.

Neste mesmo forno fez-se tratamento térmico de homogeneização em amostras provenientes do processo caster a uma temperatura de $550^{\circ} \mathrm{C}$, variando-se o tempo, num total de 7 tempos diferentes $(2,4,8,1632,64$ e 120 h). Após o tempo de permanência, as amostras foram resfriadas em água com gelo.

Com o intuito de se comparar o efeito da homogeneização antes da laminação a frio, duas placas foram laminadas no laminador duo reversível instalado no Departamento de Engenharia Metalúrgica e de Materiais da EPUSP. O tratamento térmico para homogeneização de uma placa (dimensão da placa: $200 \mathrm{~mm}$ x $35 \mathrm{~mm}$ x 7,4 $\mathrm{mm}$ ) a ser laminada a frio foi feito a $550^{\circ} \mathrm{C}$ por 24 horas em uma mufla da marca Lindberg. A amostra foi resfriada em água com gelo. Após laminação a frio, amostras com $91 \%$ de redução, das duas placas, sofreram tratamentos térmicos entre $100^{\circ} \mathrm{C} \mathrm{e}$ $550^{\circ} \mathrm{C}$ por 1 hora, para estudo da recristalização (forno tubular da marca Lindberg instalado no Departamento de Engenharia de Materiais - Faenquil - Lorena/SP).

As amostras foram colocadas no forno somente quando o forno atingia a temperatura desejada. 


\subsubsection{Microdureza Vickers}

As amostras foram lixadas utilizando-se lixas de carboneto de silício de 220, 320, 400, 600 e 1000, e posterior polimento com pasta de diamante com as granulometrias de 6,3 e $1 \mu \mathrm{m}$. O polimento final foi feito com solução OP-S (sílica coloidal).

As medidas de microdureza foram feitas em um microdurômetro Micromet da Buehler, instalado no Departamento de Engenharia Mecânica da EPUSP ou outro, da mesma marca, instalado no Departamento de Engenharia de Materiais da Faenquil Lorena, com carga de 100 gf e 50 gf.

\subsubsection{Resistividade elétrica}

As medidas de resistência elétrica das amostras foram realizadas pelo método das quatro pontas. Utilizando-se tinta prata foram colocados quatro contatos nas amostras. As amostras são fixadas em um bloco de cobre (porta-amostra) juntamente com um sensor de temperatura. Elas são excitadas por uma corrente que varia de zero até cerca de 0,5 A. Para uma dada corrente de excitação I, a partir da leitura da tensão V, a resistência elétrica na amostra é obtida a partir da relação:

$\mathrm{V}=\mathrm{R} * \mathrm{I}$

Após a obtenção da curva $\mathrm{V}(\mathrm{I})$ em temperatura ambiente, as amostras são mergulhadas em nitrogênio líquido $(77 \mathrm{~K})$ e o mesmo procedimento é repetido. A resistência elétrica é obtida a partir do ajuste linear dos pontos da curva I-V. O equipamento utilizado está instalado no Departamento de Engenharia de Materiais da Faenquil - Lorena.

\subsubsection{Condutividade elétrica}

A condutividade elétrica foi medida utilizando-se um condutímetro de contato, instalado na CBA - Companhia Brasileira de Alumínio. O condutímetro é digital, modelo DC-09. É um instrumento para ensaio não destrutivo que mede a condutividade elétrica de 
metais e expressa os resultados diretamente em \%IACS. A unidade \%IACS (International Annealed Copper Standard) expressa a condutividade dos metais como percentual da condutividade do cobre puro padrão. O condutímetro está calibrado para fornecer os valores de condutividade a $20^{\circ} \mathrm{C}$, mesmo que a temperatura seja diferente deste valor. Para isto, utiliza-se um padrão de alumínio calibrado, o que garante a precisão dos resultados. Uma superfície plana de pelo menos $10 \mathrm{~mm}$ é requerida para a amostra. O acabamento superficial deve ser de uma lima fina, não sendo necessário polir ou retificar. A precisão é de +/- 1\% IACS e a resolução é de $0,1 \%$. 


\section{RESULTADOS E DISCUSSÃO DOS RESULTADOS}

Os resultados serão apresentados e discutidos na seguinte seqüência:

1. Caracterização inicial das amostras provenientes dos processos "caster" e laminada a quente;

2. Análise de textura dos processos "caster" e laminada a quente;

3. Microestrutura e textura de laminação a frio de amostras provenientes do processo "caster";

4. Microestrutura, textura e microtextura de recristalização de amostras provenientes do processo "caster";

5. Estudo do efeito do tratamento térmico prévio de homogeneização no encruamento e na posterior recristalização;

6. Comparação entre EBSD e difração de raios X;

7. Técnicas de extração de precipitados;

8. Estudo da transformação do precipitado $\mathrm{Al}_{6} \mathrm{Mn}$ durante tratamentos de homogeneização; e

\subsection{Caracterização microestrutural inicial das amostras provenientes dos processos caster e laminada a quente}

No processo "roll caster" o metal entra na região de laminação a uma temperatura próxima ao ponto de fusão da liga. A solidificação do metal começo no ponto de primeiro contato com o cilindro, sendo portanto antes do ponto de mordedura. O volume de processamento pode ser dividido em três partes distintas [Miyazawa, 1981]: zona líquida; zona pastosa; área de redução a quente. Na zona líquida o metal vai perdendo temperatura e inicia a formação dos núcleos de solidificação. Na zona pastosa estes núcleos formam-se e imediatamente começam a crescer. A terceira e última zona é a sólida, onde o metal já solidificado sofre a deformação imposta pelos cilindros, o material fica com os grãos alinhados no sentido da laminação. Eles deformam-se plasticamente quando o material passa pelos cilindros. $\mathrm{O}$ metal deixa os cilindros com uma temperatura ao redor de $300^{\circ} \mathrm{C}$. 
A deformação, portanto, ocorre na faixa de temperatura entre a solidus e $300^{\circ} \mathrm{C}$ [Tricibar, 1999]. A temperatura de saída relativamente baixa impede a recristalização, deixando a tira numa condição deformada. Em estudos similares verificou-se que a deformação introduzida durante o processo caster corresponde a 10-25\% de redução em área por laminação a frio [Westengen, 2000].

Na Tabela 8 são apresentados valores de microdureza Vickers da chapa laminada a quente e da chapa caster ao longo da espessura: superfície, 1/4 da espessura abaixo da superfície e no centro da chapa. Pode-se perceber que houve uma pequena diferença ao longo da espessura, revelando que a deformação é maior na superfície, como já era esperado, devido à maior pressão exercida pelos cilindros na superfície. Esta diferença ao longo da espessura não tem relação com a composição química, pois como foi visto na Tabela 6, do item anterior, não há variação significativa de composição química ao longo da espessura.

A diferença da microdureza entre caster e laminada a quente pode ser explicada pelos mecanismos de endurecimento. Existem 5 mecanismos de endurecimento mais comuns: por deformação (encruamento), endurecimento por refino de grão, endurecimento por solução sólida, endurecimento por precipitação coerente e endurecimento por dispersão de partículas incoerentes. Basicamente, o endurecimento por deformação é um mecanismo eficaz de endurecimento, porém limitado pela temperatura de deformação e aos metais que apresentam alto coeficiente de encruamento, como por exemplo, os metais que possuem baixa EDE. O endurecimento por deformação promove um travamento por interação de discordâncias, restringindo bastante a sua movimentação. O endurecimento por refino de grão, em que segue a equação de Hall-Petch :

$$
\sigma=\sigma_{0}+k(d)^{-1 / 2}
$$

onde, $\sigma_{0}$ é a tensão de escoamento inicial, $\mathrm{k}$ é uma constante e d é o diâmetro do grão

Esta equação relaciona a tensão de escoamento ao tamanho de grão elevado a - 1/2, ou seja, quando se leva em consideração a dificuldade em se obter material com tamanhos de grãos em uma faixa de tamanho que promova um efetivo endurecimento pode-se chegar a conclusão de que este mecanismo não é tão eficaz. O endurecimento por refino de grão é 
causado pelos contornos de grãos, que são barreiras para a movimentação das discordâncias. $\mathrm{O}$ endurecimento por solução sólida é um importante mecanismo, porém limitado no caso do alumínio, pelas baixas solubilidades dos solutos mais comuns. Os átomos de soluto em solução sólida distorcem a rede cristalina da matriz (sendo a solução sólida intersticial mais efetiva), dificultando a movimentação das discordâncias. O endurecimento por precipitação coerente produz ligas com alta resistência. A precipitação coerente não impede por completo a movimentação das discordâncias, porém quando os precipitados são cisalhados promovem o aparecimento de contornos de antifase e aumento de superfície de interface. $\mathrm{O}$ endurecimento por dispersão de precipitados incoerentes promove um aumento da quantidade de discordâncias (pela formação de anéis de discordâncias, depois da sua passagem pelo precipitado). Como já foi dito no capítulo 2 , a liga 3003 não apresenta precipitados coerentes, portanto não é endurecível por tratamento térmico. A diferença de dureza encontrada entre as amostras provenientes do processo caster e laminação a quente pode ser explicada pelo mecanismo de endurecimento por deformação ou encruamento. Comparando-se as Figuras 36 e 37 com as Figuras 50 e 51 observa-se que a densidade de discordâncias da amostra caster é relativamente maior que na amostra laminada a quente. Pode-se afirmar que a amostra caster sofre apreciável deformação plástica durante seu processamento, pois se nota a presença de estrutura celular de discordâncias e discordâncias livres encontradas em subgrãos (Figuras 36 e 37). A diferença de dureza também pode estar associada ao tamanho de grão menor na amostra caster (Figuras 25 e 42). E, por último, pode estar associada também à quantidade de soluto em solução sólida. Pois devido à alta taxa de resfriamento durante solidificação no processo "roll caster", o grau de supersaturação de elementos de liga, principalmente manganês, é bastante alto [Berg et al, 1995; Zhou et al, 2003]. (A quantidade de soluto em solução sólida foi avaliada por meio de medidas e condutividade elétrica e serão discutidas no próximo parágrafo.) Portanto, estes três mecanismos podem estar atuando conjuntamente e por isso a amostra caster possui dureza maior que a laminada a quente.

A relação entre condutividade elétrica, $\sigma$, da liga 3003 e as concentrações dos elementos de liga em solução sólida pode ser expressa como [Li, 2003 b]:

$1 / \sigma=0,0267+0,032 \mathrm{Fe}_{\mathrm{ss}} \%+0,033 \mathrm{Mn}_{\mathrm{ss}} \%+0,0068 \mathrm{Si}_{\mathrm{ss}} \%+0,0032 \mathrm{Cu}_{\mathrm{ss}} \%$ 
onde, $\mathrm{Fe}_{\mathrm{ss}} \%, \mathrm{Mn}_{\mathrm{ss}} \%, \mathrm{Si}_{\mathrm{ss}} \%$ e $\mathrm{Cu}_{\mathrm{ss}} \%$ são as porcentagens em peso dos elementos em solução sólida.

Devido à existência desta relação entre condutividade elétrica e elementos de liga em solução sólida, a supersaturação de elementos de liga do caster em relação a laminada a quente pode ser comprovada comparando-se a condutividade elétrica de amostras provenientes do dois processos. Como pode ser visto na equação acima, $\mathrm{Si}_{\mathrm{ss}} \%$ e $\mathrm{Cu}_{\mathrm{ss}} \%$ tem menor influência na condutividade elétrica que $\mathrm{Mn}_{\mathrm{ss}} \%$. Tem sido detectado em lingotes brutos de fundição da liga 3003 que quase todo o Fe forma partículas intermetálicas, enquanto grande parte do Mn está em solução sólida durante a solidificação [Li, 2003 b]. Por outro lado, as variações de condutividade ocasionadas por defeitos cristalinos são comparativamente desprezíveis. Portanto, a evolução da condutividade elétrica pode ser utilizada para estimar a concentração de Mn em solução sólida e dar indicação detalhada da reação de decomposição da solução sólida supersaturada durante o processamento mecanotérmico. A condutividade elétrica medida da amostra caster bruta de fundição é de apenas $29,9 \%$, enquanto para a amostra laminada a quente a condutividade medida foi de 40,8\%, ou seja, na amostra caster bruta de fundição há uma apreciável supersaturação de elementos de liga em solução sólida, quando comparada com a laminada a quente. Quando o tratamento térmico de homogeneização a $500^{\circ} \mathrm{C}$ por $12 \mathrm{~h}$ é feito na amostra caster, a condutividade medida aumenta de $29,9 \%$ para $49 \%$, causada pela diminuição de soluto em solução sólida, ou seja, pela precipitação.

Tabela 8. Valores de microdureza Vickers (300g) da amostra laminada a quente e da amostra caster ao longo da espessura: superfície, $1 / 4$ da espessura abaixo da superfície e no centro da chapa.

\begin{tabular}{|c|c|}
\hline Processo: posição & Microdureza (HV) \\
\hline Chapa Laminada: superfície & $42 \pm 1$ \\
\hline Chapa Laminada: $\mathbf{1 / 4}$ & $40 \pm 1$ \\
\hline Chapa Laminada: centro & $41 \pm 1$ \\
\hline Caster: superfície & $54 \pm 1$ \\
\hline Caster: 1/4 & $52 \pm 1$ \\
\hline Caster: centro & $52 \pm 1$ \\
\hline
\end{tabular}


Nas Figuras 24 e 25 são apresentadas as microestruturas da amostra caster, nas secções normal, longitudinal e transversal. É possível observar a estrutura dendrítica no interior dos grãos. Nota-se que os grãos estão bastante alongados na seção longitudinal. A Figura 26 revela que a distribuição de tamanho de grão é homogênea ao longo da espessura, apresentando grãos finos. A região central e $1 / 4$ da espessura revelam grãos relativamente equiaxiais sugerindo que a deformação durante o lingotamento foi mais acentuada na superfície.

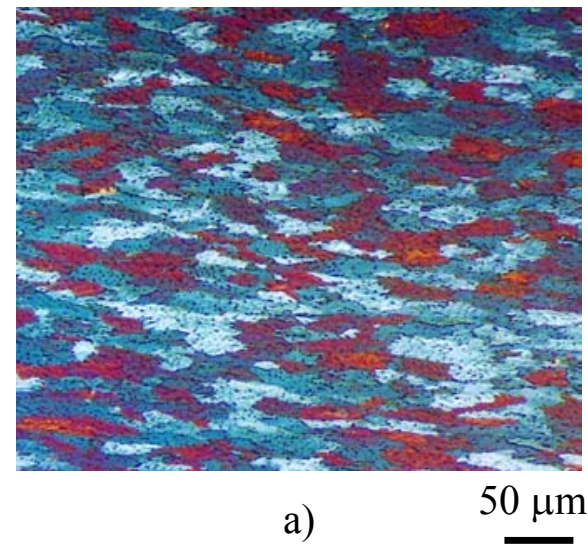

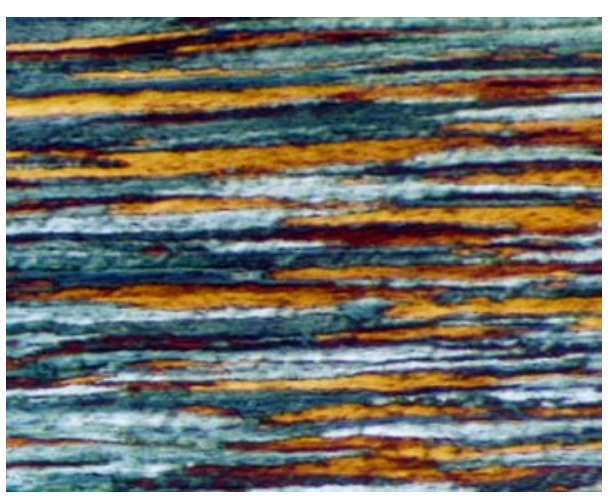

b)

Figura 24 - a) Microestrutura na seção transversal da amostra caster (bruta de fundição); b) Microestrutura na seção longitudinal da amostra caster (bruta de fundição). Amostra anodizada com solução contendo ácido fluobórico. Microscopia óptica sob luz polarizada. Direção de laminação paralela à direção horizontal. 


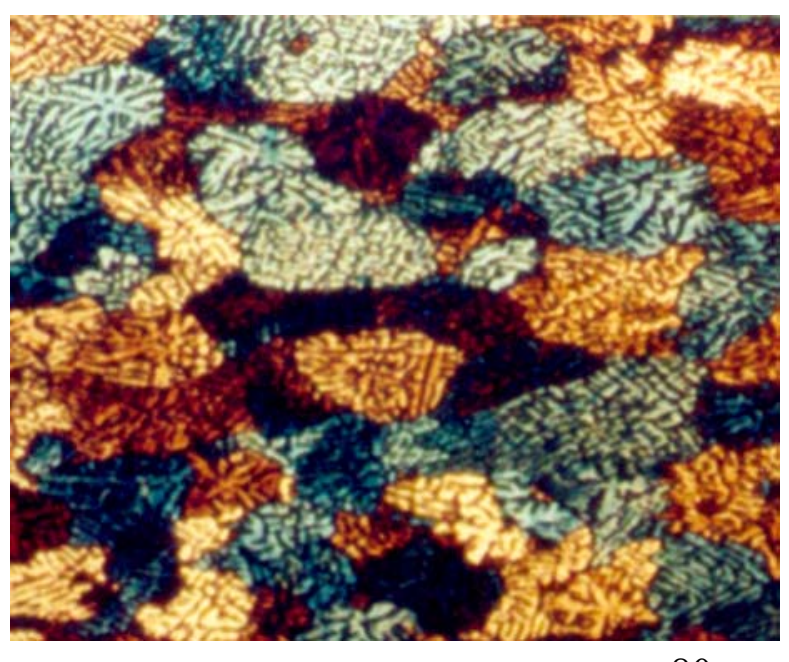

$80 \mu \mathrm{m}$

Figura 25 - Microestrutura da superfície da amostra caster (bruta de fundição). Amostra anodizada com solução contendo ácido fluobórico. Microscopia óptica sob luz polarizada. Direção de laminação paralela à direção horizontal.

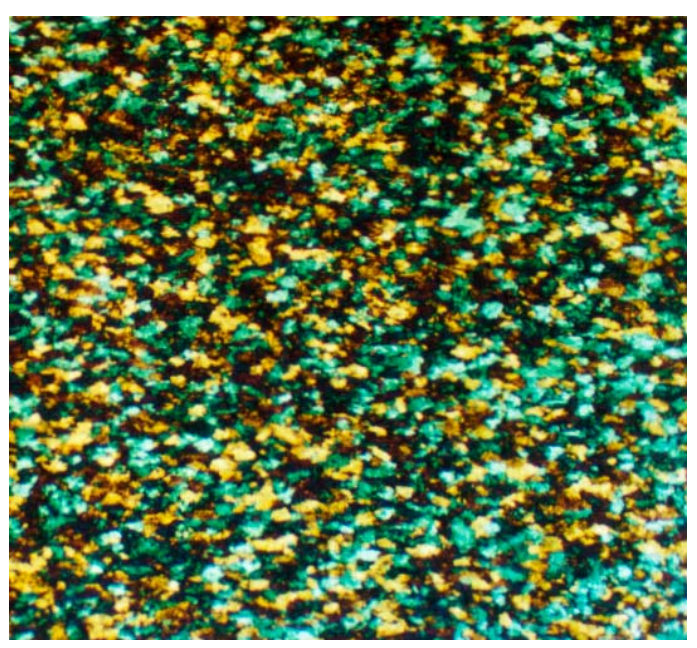

a)

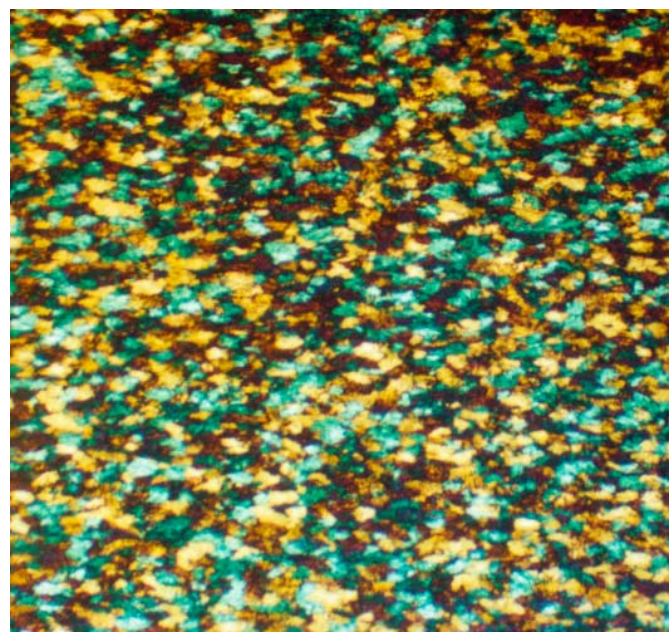

b)

$1 \mathrm{~mm}$

Figura 26 - Microestrutura mostrando a distribuição dos grãos na amostra caster ao longo da espessura, microscopia óptica sob luz polarizada: a) região central; b) região $1 / 4$ da espessura. Amostra anodizada com solução contendo ácido fluobórico. Direção de laminação paralela à direção horizontal. 


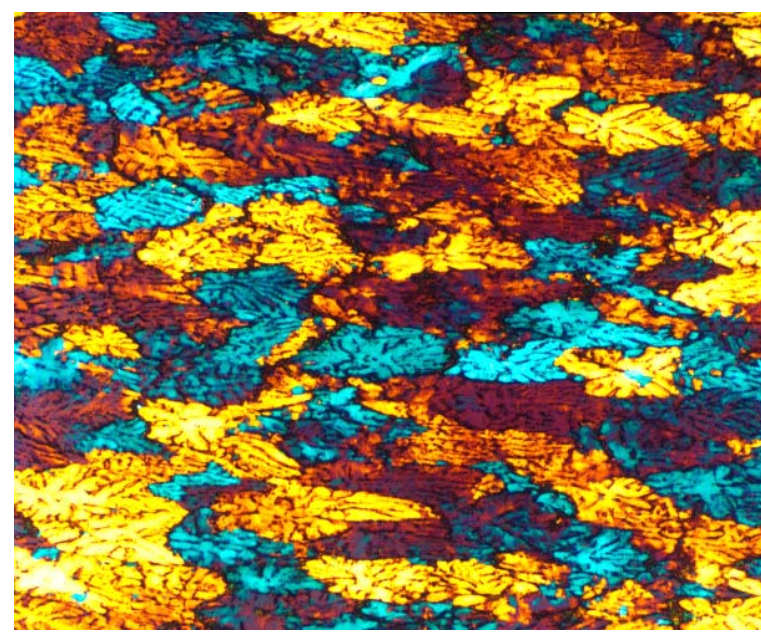

a)

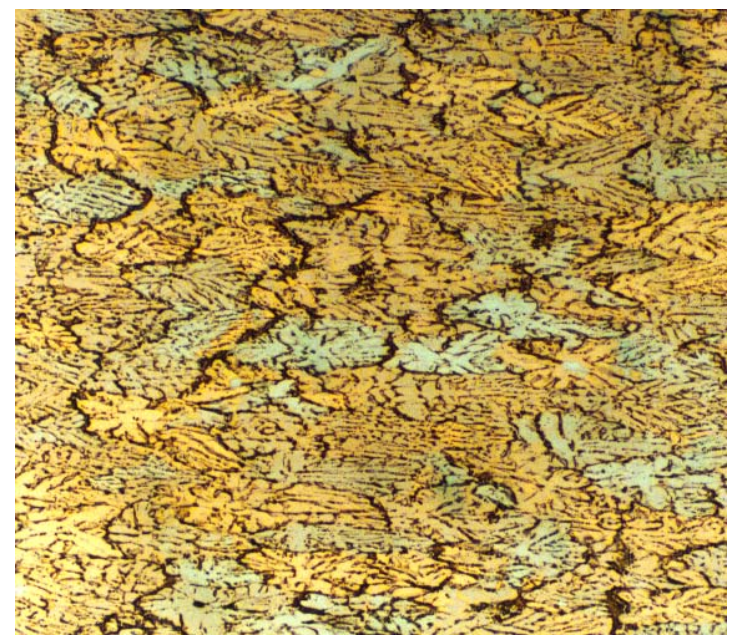

$0,2 \mathrm{~mm}$

b)

Figura 27 - a)Microestrutura da amostra caster na região central, microscopia óptica sob luz polarizada; b)Mesma região mostrada em a, microscopia óptica sem luz polarizada. Amostra anodizada com solução contendo ácido fluobórico. Direção de laminação paralela à direção horizontal. 

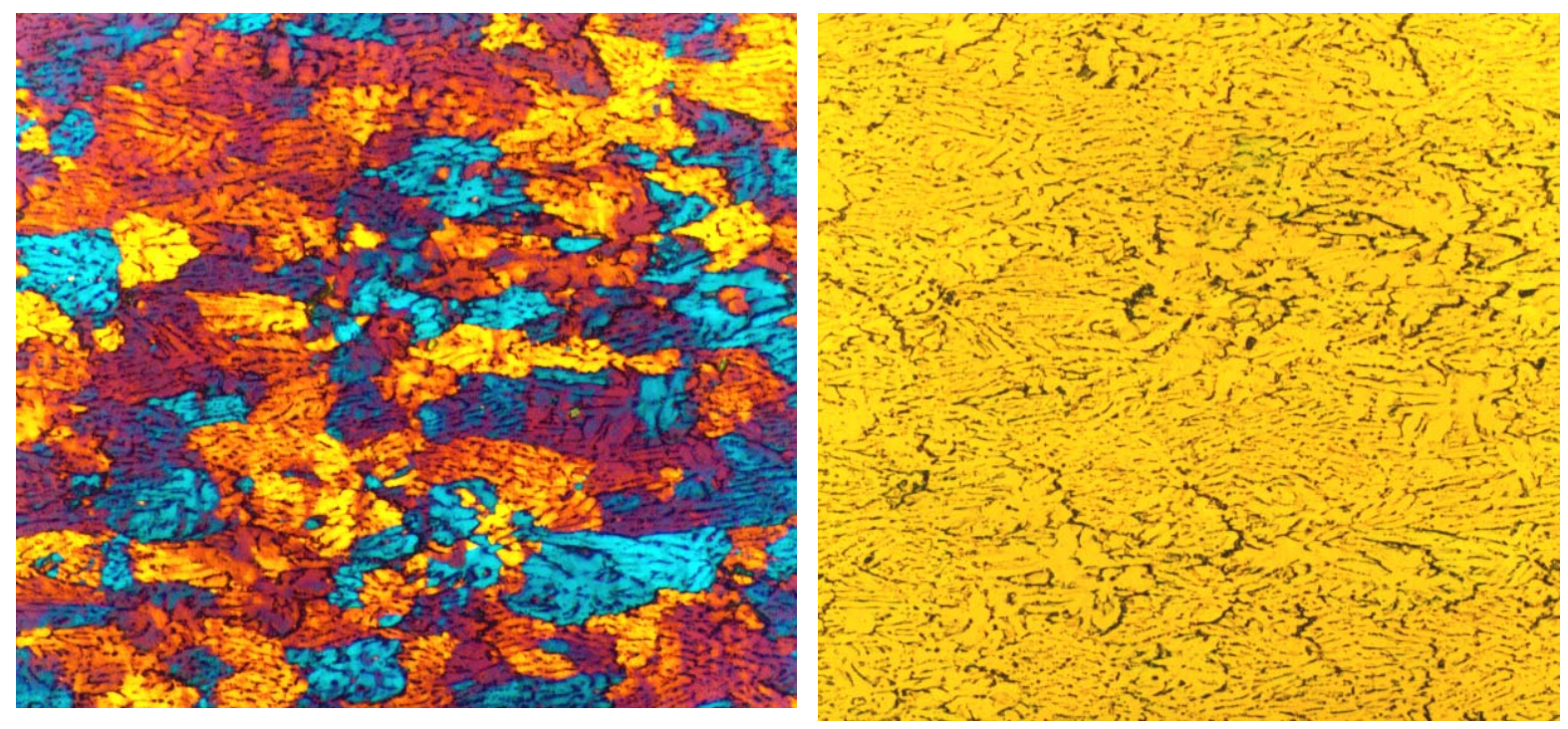

a)

b)

$100 \mu \mathrm{m}$

Figura 28 - a)Microestrutura da amostra caster na região $1 / 4$ da superfície, microscopia óptica sob luz polarizada; b)Mesma região mostrada em a, microscopia óptica sem luz polarizada. Amostra anodizada com solução contendo ácido fluobórico. Direção de laminação paralela à direção horizontal.

A Figura 27 apresenta a estrutura de grãos encontrada na região central (metade da espessura) da amostra caster. Comparando-se as Figuras 27a/27b e 28a/28b percebe-se a incidência de precipitados ocorre principalmente nos contornos de grão. Nota-se que a precipitação ocorre com mais freqüência na região central da amostra. Utilizando-se a determinação da fração volumétrica de precipitados, por meio da técnica de microscopia óptica em campo escuro, seguida de análise de imagens, foi possível comprovar que na região central da chapa caster bruta de fundição a fração de precipitados é maior (Tabela 9). É provável que o uso de campo escuro e análise automática de imagens superestime a quantidade de precipitados, mas mesmo assim as comparações entre amostras diferentes são válidas. É interessante ressaltar que há diferença de fração volumétrica de precipitados ao longo da espessura, mas não há variação de composição química como já foi dito (vide Tabela 6). Estudos a partir de modelos matemáticos de fluxo de fluídos e transferência de calor [Saxena, 2002] revelam que há níveis ou contornos de temperatura, ou seja, enquanto 
a temperatura da superfície da chapa está menor (como por exemplo, 300K para a liga Al$4,5 \% \mathrm{Cu}$ ) devido ao contato com os cilindros refrigerados, a temperatura da região da zona líquida (como descrita no início desta seção) encontra-se ainda bastante alta (920K para a liga $\mathrm{Al}-4,5 \% \mathrm{Cu})$ Esta diferença de temperatura ao longo da espessura pode explicar a fração volumétrica de precipitados maior na região $1 / 2$ de espessura da amostra caster, devido à variação de solidificação da superfície para o centro.

Tabela 9 - Medida de fração volumétrica de precipitados ao longo da espessura das amostras provenientes do processo roll caster e da laminação a quente.

\begin{tabular}{|l|l|c|}
\hline & Caster & Laminada a quente \\
\hline superfície & $4,2 \pm 0,8$ & $4,0 \% \pm 1,1$ \\
\hline $1 / 4$ & $5,2 \pm 0,7$ & $3,6 \% \pm 0,8$ \\
\hline $1 / 2$ & $6,3 \pm 0,9$ & $4,1 \% \pm 0,7$ \\
\hline
\end{tabular}
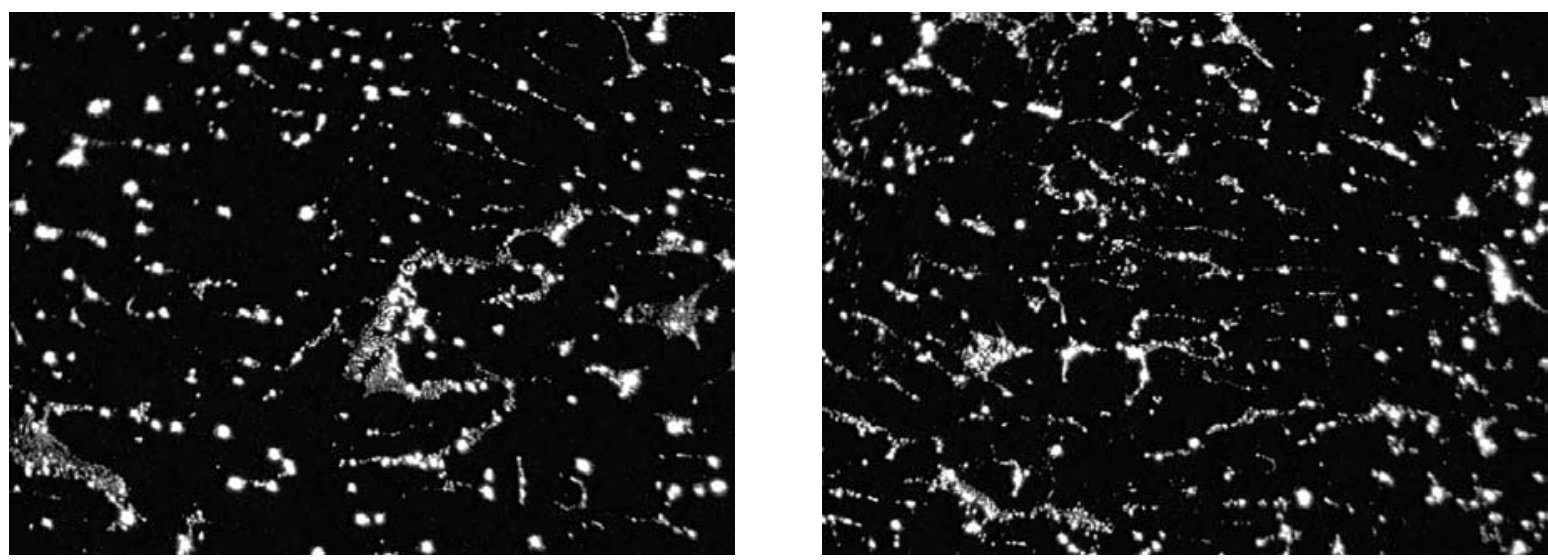

Figura 29 - Caster bruta de fundição, 1/2 da espessura. Exemplos de imagens obtidas por microscopia óptica em campo escuro. Aumento de 1000 X. Amostra atacada com solução contendo ácido fluorídrico. 

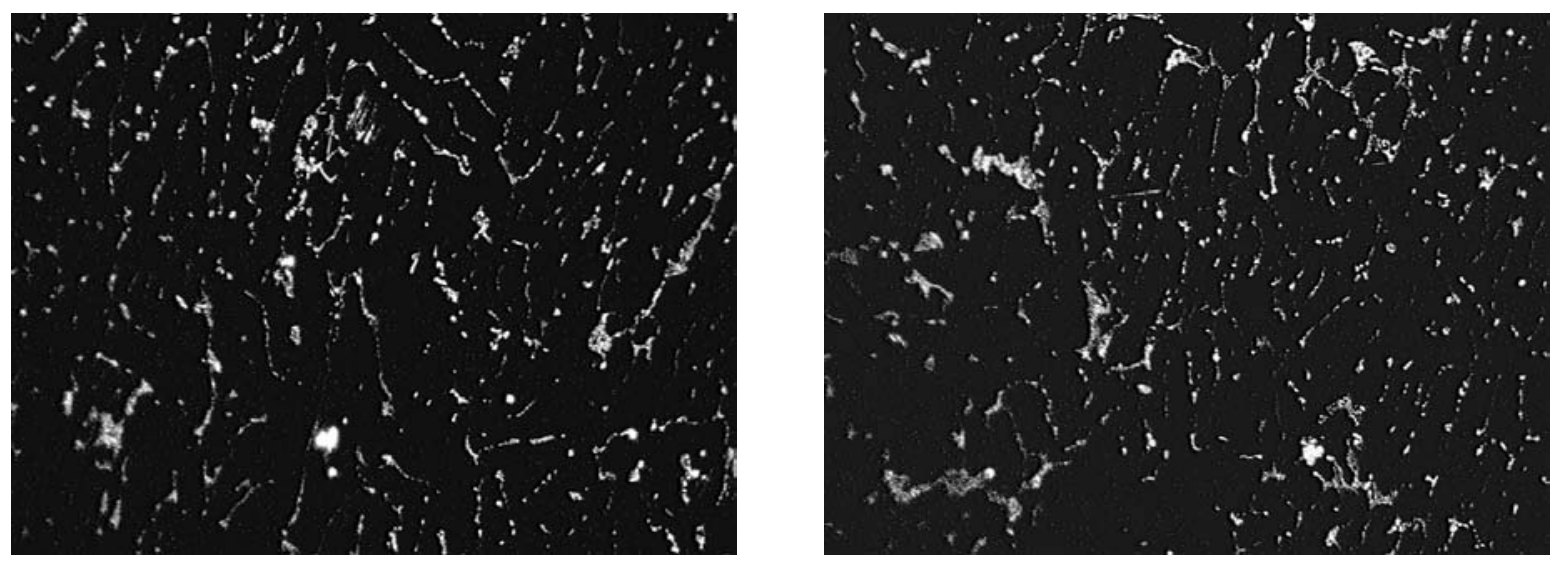

Figura 30 - Caster bruta de fundição, $1 / 4$ da espessura. Exemplos de imagens obtidas por microscopia óptica em campo escuro. Aumento de $1000 \mathrm{X}$. Amostra atacada com solução contendo ácido fluorídrico.
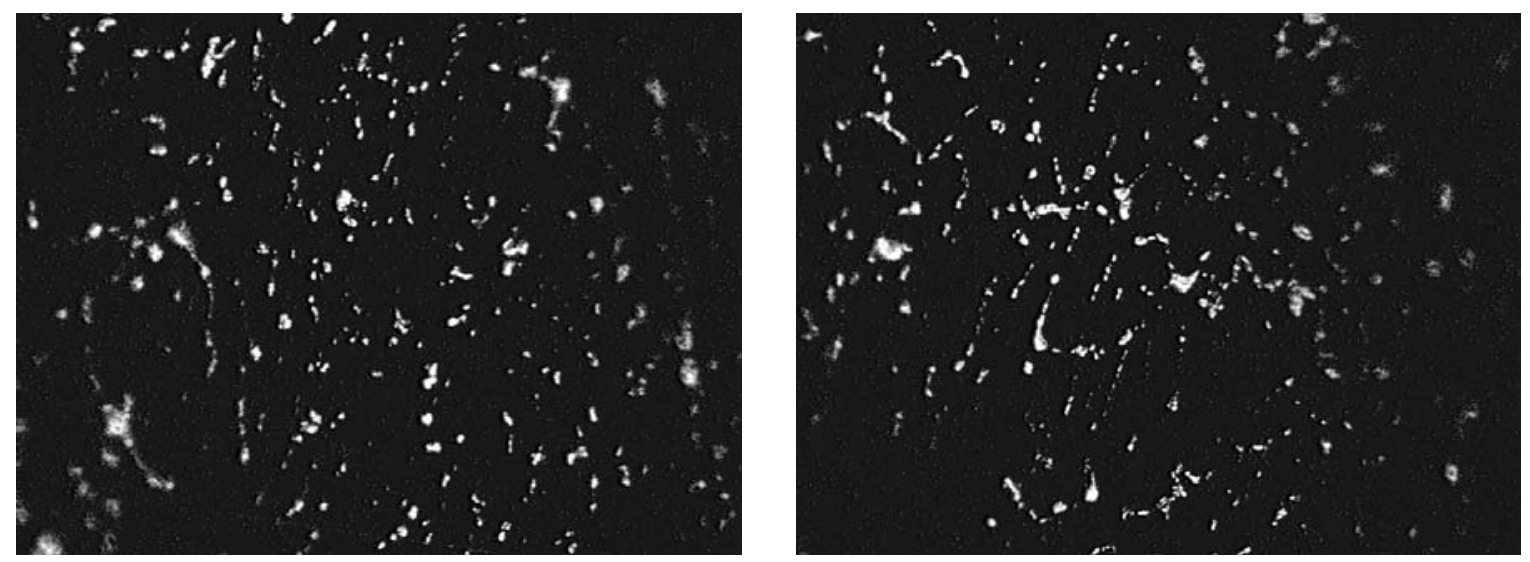

Figura 31 - Caster bruta de fundição, superfície. Exemplos de imagens obtidas por microscopia óptica em campo escuro. Aumento de 1000 X. Amostra atacada com solução contendo ácido fluorídrico.

Com o auxílio de microscopia óptica, determinou-se o tamanho médio de precipitados. Partículas menores que $0,5 \mu \mathrm{m}$ não foram consideradas, uma vez que o limite de resolução do microscópio ótico é desta ordem. A distribuição do tamanho médio de precipitados encontra-se na Figura 32. 


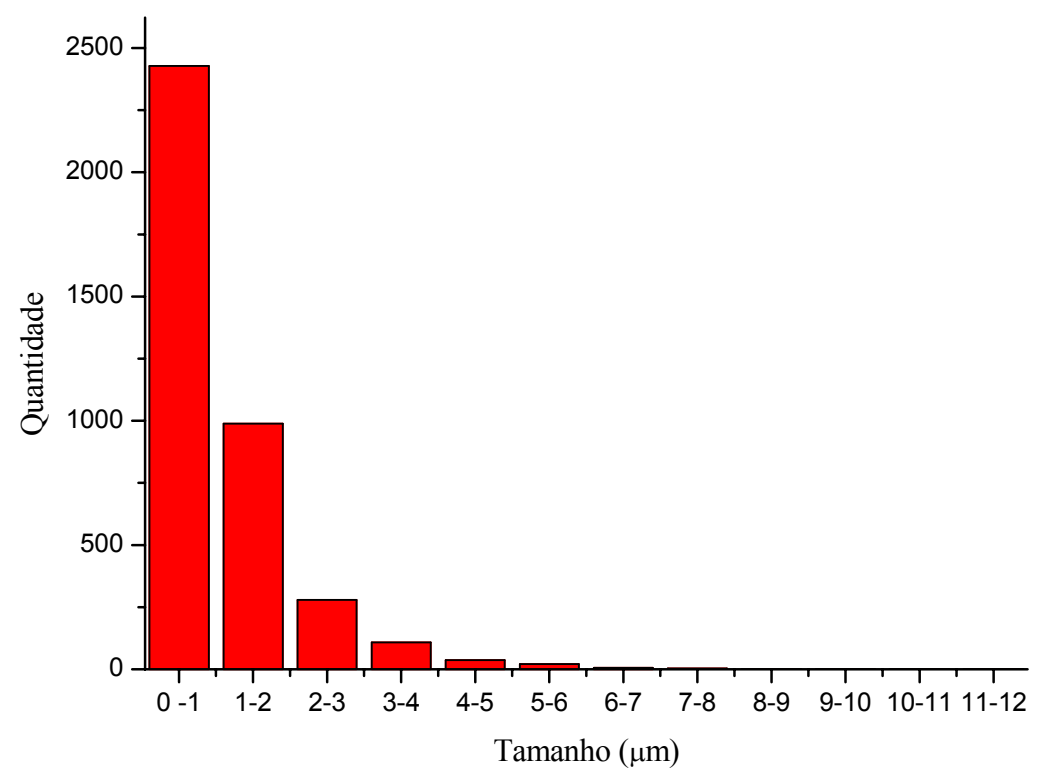

Figura 32 - Distribuição do tamanho médio de precipitados da amostra caster na região da superfície.

Como já foi dito, o caster apresentou considerável variação na quantidade e distribuição das partículas de segunda fase ao longo da espessura. A Figura 33 apresenta micrografias de região próxima da superfície (Figura 33a e 33b) e da região central (Figura 33c e 33d), obtidas no microscópio eletrônico de varredura com auxílio de elétrons retroespalhados. Enquanto a região próxima da superfície apresenta partículas individualizadas e em menor quantidade, a região central apresenta considerável incidência de colônias lamelares, situadas nas regiões interdendríticas. É interessante lembrar, que as regiões mais claras nas imagens com elétrons retroespalhados, tais como os precipitados, apresentam número atômico médio mais elevado, ou seja, são mais ricos em manganês e ferro que a matriz. Este tipo de comportamento é esperado, pois os elementos formadores de eutéticos, tais como ferro, manganês e silício, em geral segregam nas regiões interdendríticas. A microestrutura das ligas de alumínio no estado bruto de solidificação em geral apresenta dendritas com enriquecimento central em alumínio e em elementos formadores de peritético $(k>1)$, enquanto os elementos formadores de eutéticos $(k<1)$ concentram-se nas regiões interdendríticas. O coeficiente de partição $(\mathrm{k})$ é o quociente entre a concentração de soluto no sólido $\left(\mathrm{C}_{\mathrm{S}}\right)$ pela concentração de soluto no líquido $\left(\mathrm{C}_{\mathrm{L}}\right)$. Os elementos formadores de peritéticos atuam adicionalmente como refinadores de grãos. 


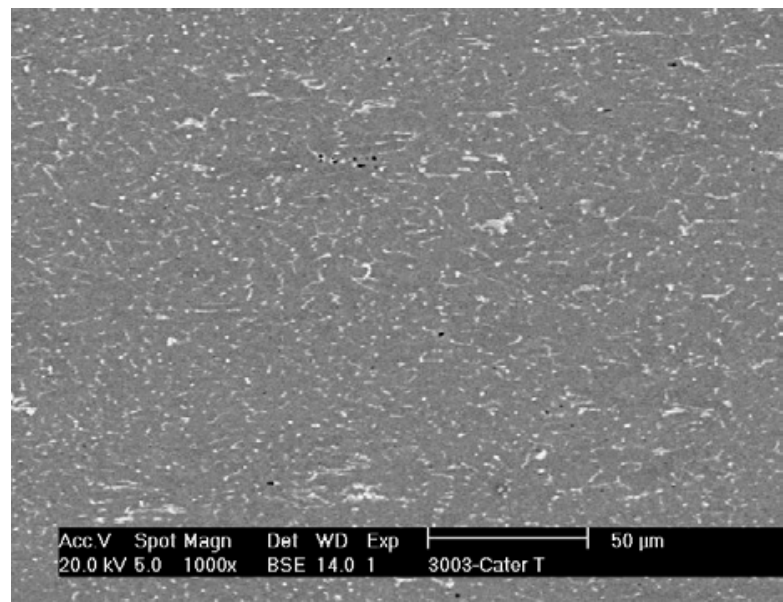

a)

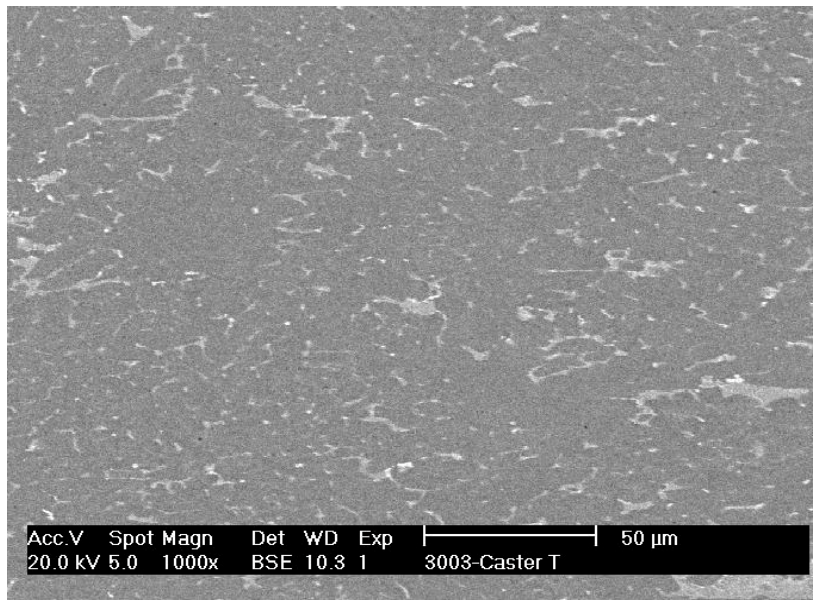

c)

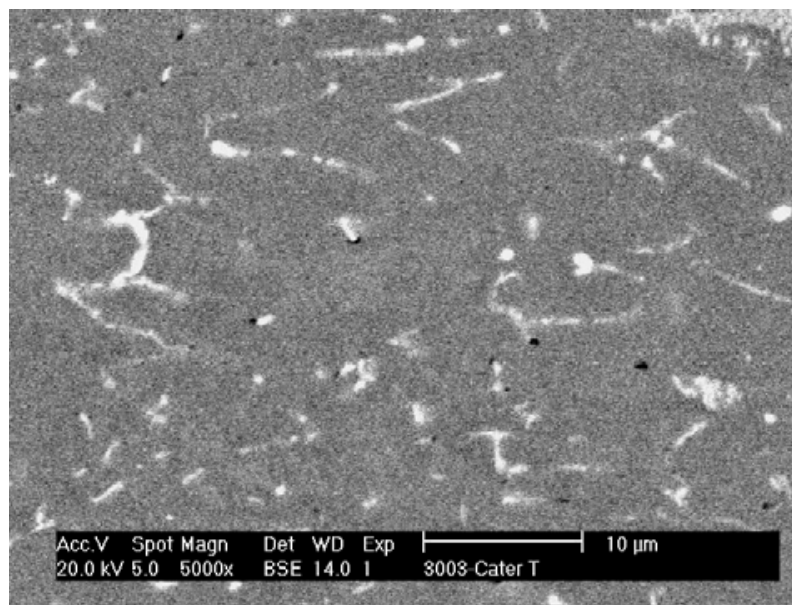

b)

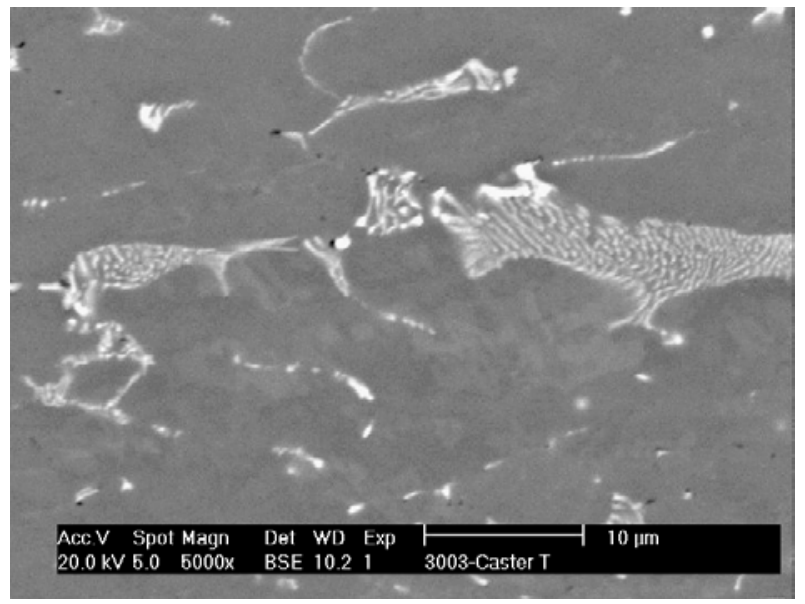

d)

Figura 33: Imagens de elétrons retroespalhados obtidas no microscópio eletrônico de varredura: a) superfície, aumento $1000 \mathrm{X}$; b) superfície, aumento $5000 \mathrm{X}$; c) centro, aumento $1000 \mathrm{X}$; d) centro, aumento $5000 \mathrm{X}$. Ataque em solução de ácido fluorídrico.

Uma amostra caster foi imersa em solução de iodo e metanol por 12 h. O alumínio começou a dissolver, formando buracos. Esta amostra foi levada ao microscópio e analisada 
com elétrons secundários, para se visualizar dentro dos buracos, desse modo, investigar como a solução ataca a liga. A solução ataca o alumínio, mas com o tempo acaba atacando os precipitados também. Isto pode ser observado na Figura 34, onde o precipitado de forma alongada está fragmentado.

Na Figura 35 podem-se observar as dendritas encontradas no caster. Os precipitados alongados são a fase $\mathrm{Al}_{6} \mathrm{Mn}$, que apresenta um formato retangular [Hansen et al, 1995].

As micrografias de transmissão, Figuras 36 a 38, revelam a estrutura de subgrãos e no interior dos subgrãos nota-se a presença de estruturas celulares de discordâncias. As discordâncias são formadas durante o processamento "roll caster" e se rearranjam em subgrãos e em estruturas celulares de discordâncias. As estruturas celulares de discordâncias são evidências da ocorrência de deformação plástica [Humphreys, 1995] em alta temperatura, durante o processamento "roll caster". Observa-se a presença de precipitados alongados localizados nos subcontornos.

A formação de subgrãos é um processo de recuperação [Blum et al, 1995]. Para a formação de subgrãos é requerido maior ativação térmica devido à necessidade de ocorrência em grande escala de escorregamento com desvio e escalada [Martin et al, 1997]. Portanto, os subgrãos são formados a altas temperaturas. Enquanto as discordâncias no interior dos subgrãos são formadas a temperaturas menores. A velocidade de resfriamento do processo "roll caster" é bastante alta $\left(200^{\circ} \mathrm{C} / \mathrm{s}\right.$ a $\left.700^{\circ} \mathrm{C} / \mathrm{s}\right)$. Portanto, a formação de subgrãos pode estar ocorrendo no início do processo, enquanto as discordâncias no interior dos subgrãos surgem no final do processo.

Foi possível observar pelos resultados apresentados até aqui que durante o processo "roll caster" há considerável deformação plástica. Com isso designar amostras provenientes deste processo como amostra bruta de fundição pode gerar polêmicas. Mas optou-se por utilizar esta nomenclatura para facilitar o entendimento de que provém de um processo de lingotamento contínuo sem ter sofrido nenhum tratamento térmico posterior ou processamento mecânico posterior. 


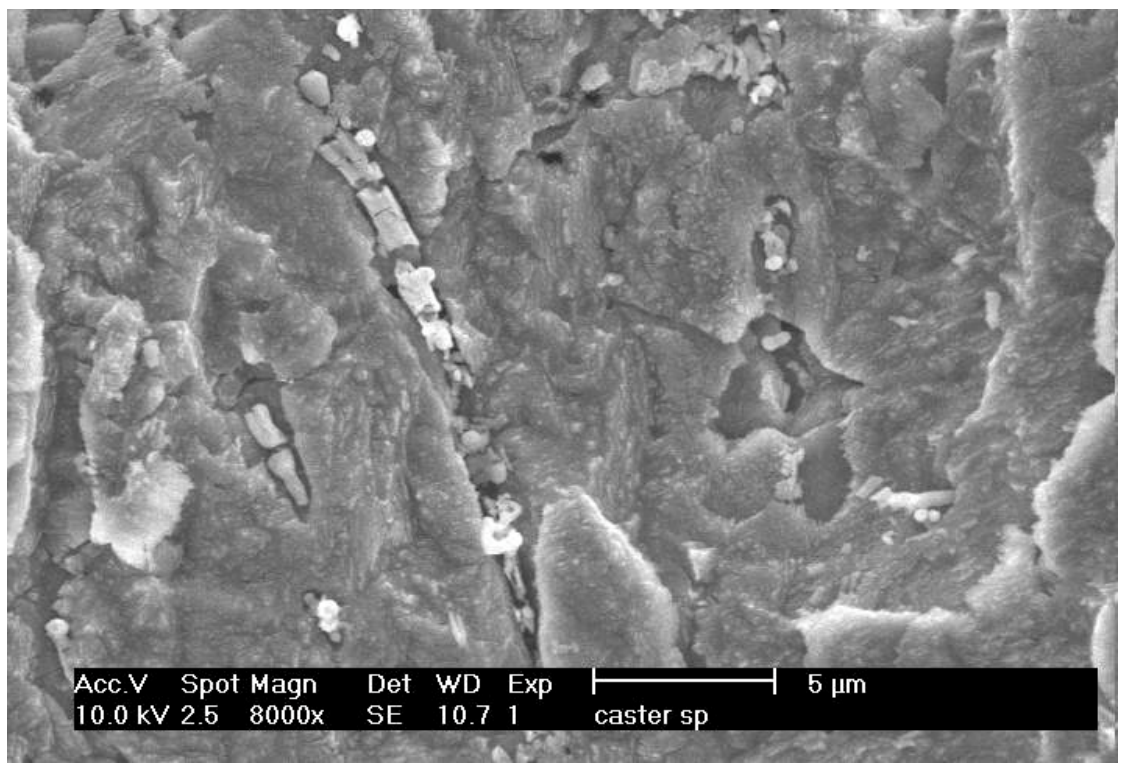

Figura 34 - Amostra caster atacada com solução de iodo e metanol por 12 h, microscopia eletrônica de varredura, elétrons secundários.

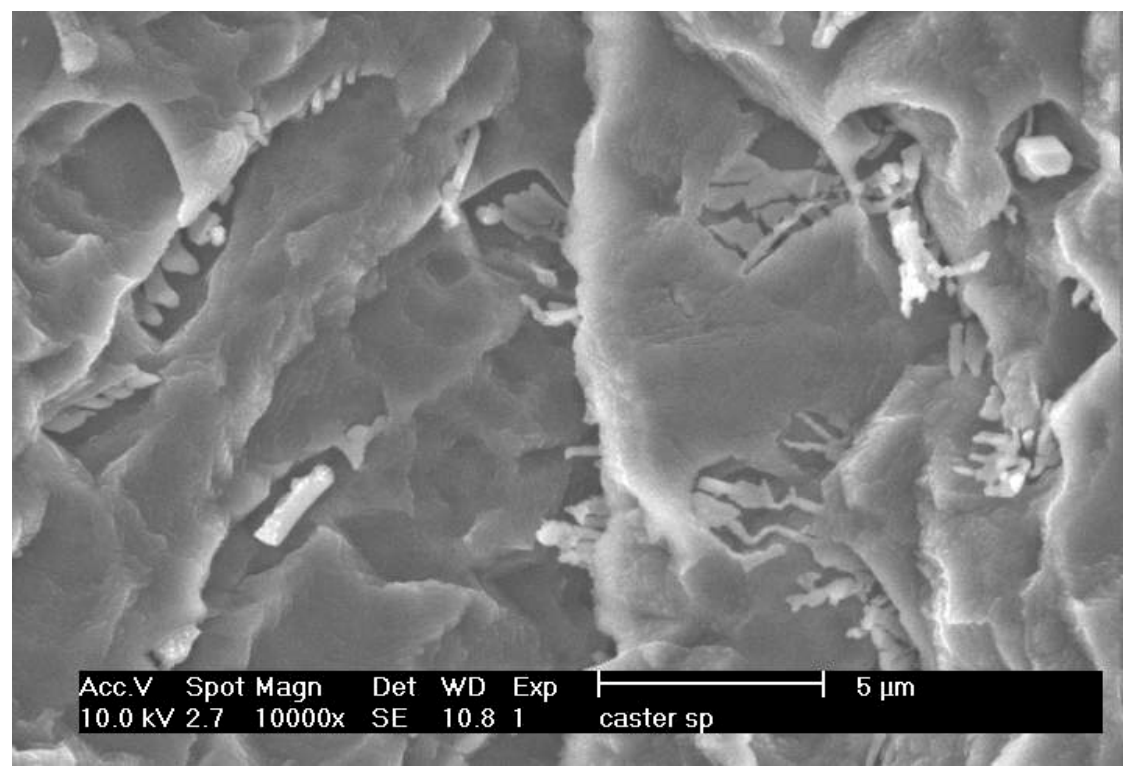

Figura 35 - Amostra caster atacada com solução de iodo e metanol por 12 horas, microscopia eletrônica de varredura, elétrons secundários. 
As partículas primárias de $\mathrm{Al}_{6}(\mathrm{Mn}, \mathrm{Fe})$ [Sperry, 1955] são encontradas com muita freqüência nas amostras caster bruta de fundição, como pode ser visto nas Figuras 39 e 40. $\mathrm{Na}$ Figura 41 encontra-se a figura de difração de elétrons do precipitado $\mathrm{Al}_{6} \mathrm{Mn}$ encontrado na amostra caster.

Analisando-se a Figura 42, nota-se que os grãos na amostra laminada a quente apresentam tamanho de grão maior que na caster. A Figura 43 apresenta a microestrutura da amostra laminada a quente na seção longitudinal. Nota-se uma microestrutura bastante heterogênea, com grãos menores na região logo abaixo da superfície seguido de grãos grosseiros. Este comportamento também foi observado na microestrutura da seção transversal. Na Figura 44, observa-se um detalhe do interior de um grão mostrando que a coloração no interior do grão muda, revelando que o grão está deformado, uma vez que regiões que sofreram rotação em relação à vizinhança apresentam regiões com coloração heterogênea. 


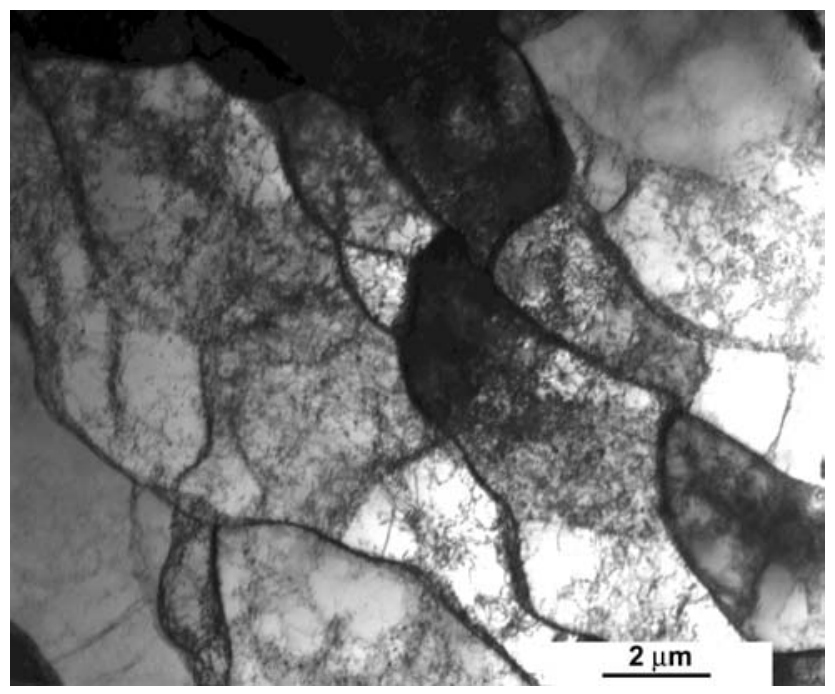

a)

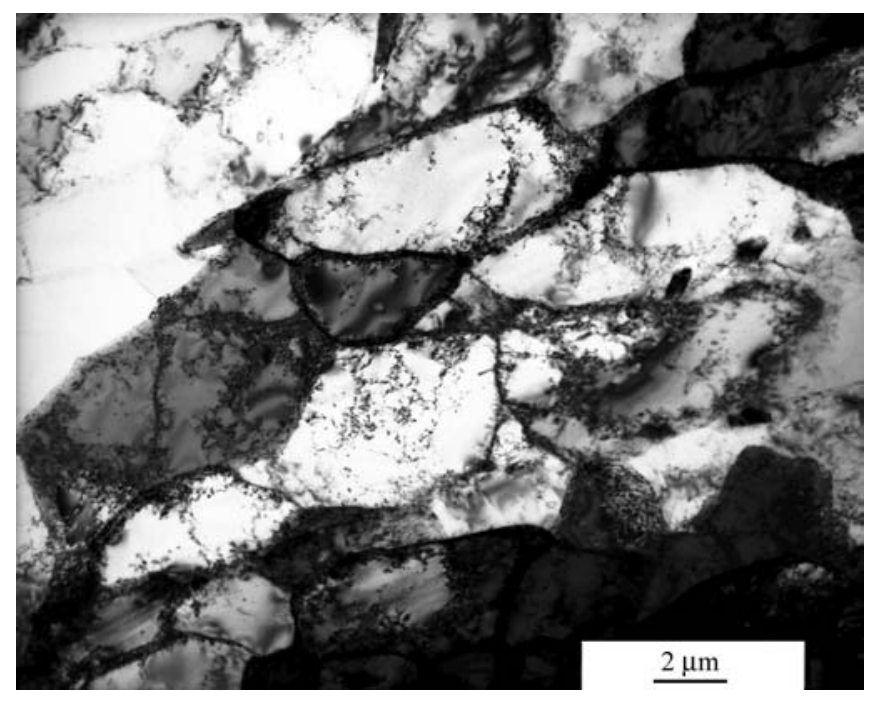

b)

Figura 36 - Microestrutura da amostra caster revelando a presença de subgrãos, microscopia eletrônica de transmissão. Amostra afinada eletroliticamente com solução contendo ácido perclórico. 


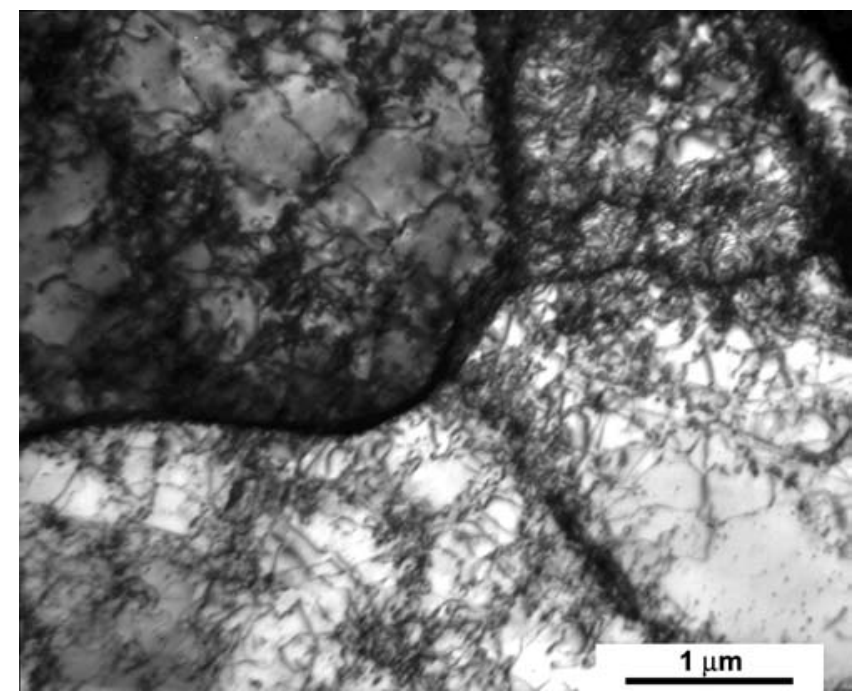

a)

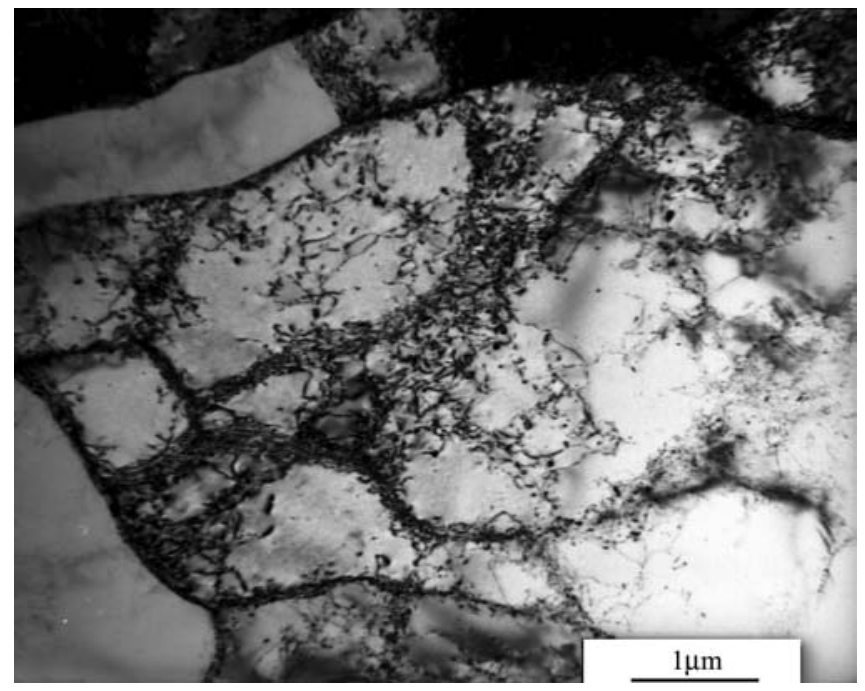

b)

Figura 37 - Microestrutura da amostra caster revelando a presença de discordâncias no interior do subgrão, microscopia eletrônica de transmissão. Amostra afinada eletroliticamente com solução contendo ácido perclórico. 


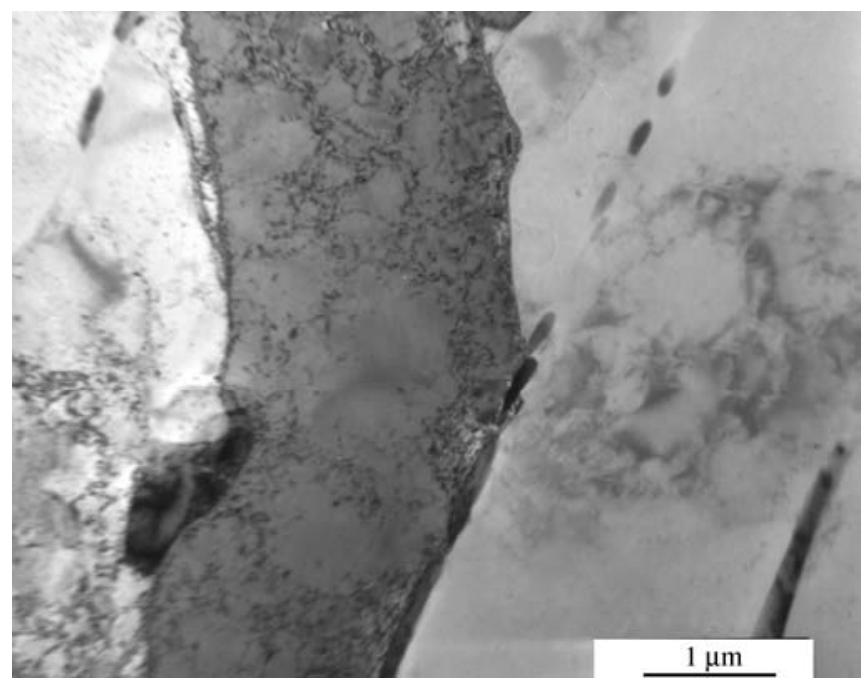

Figura 38 - Microestrutura da amostra caster revelando a presença de precipitados nos subgrãos, microscopia eletrônica de transmissão. Amostra afinada eletroliticamente com solução contendo ácido perclórico.

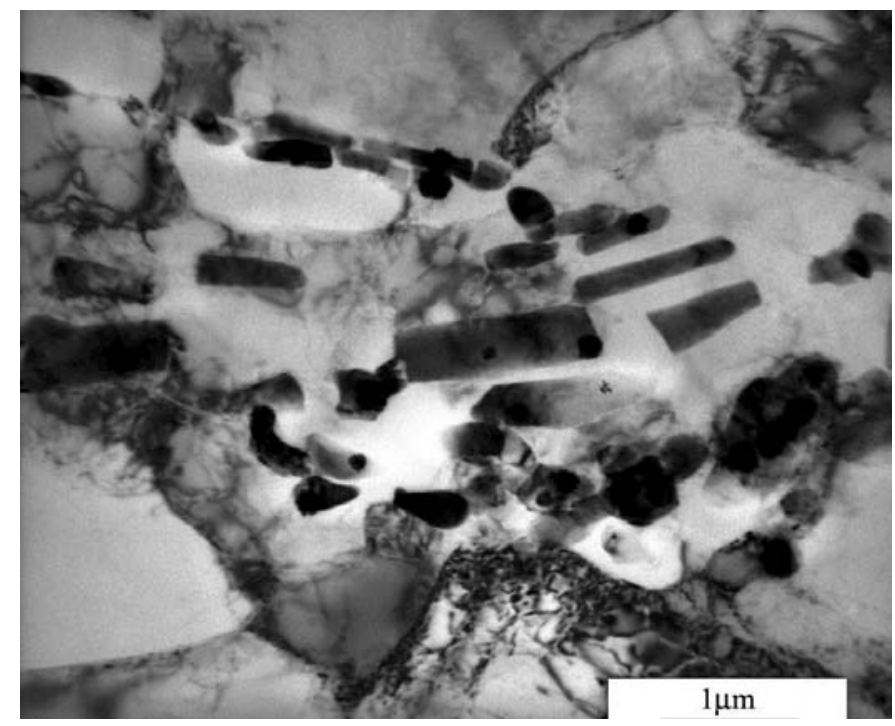

Figura 39 - Microestrutura da amostra caster revelando a presença de muitos precipitados retangulares $\left(\mathrm{Al}_{6} \mathrm{Mn}\right)$, microscopia eletrônica de transmissão. Amostra afinada eletroliticamente com solução contendo ácido perclórico. 


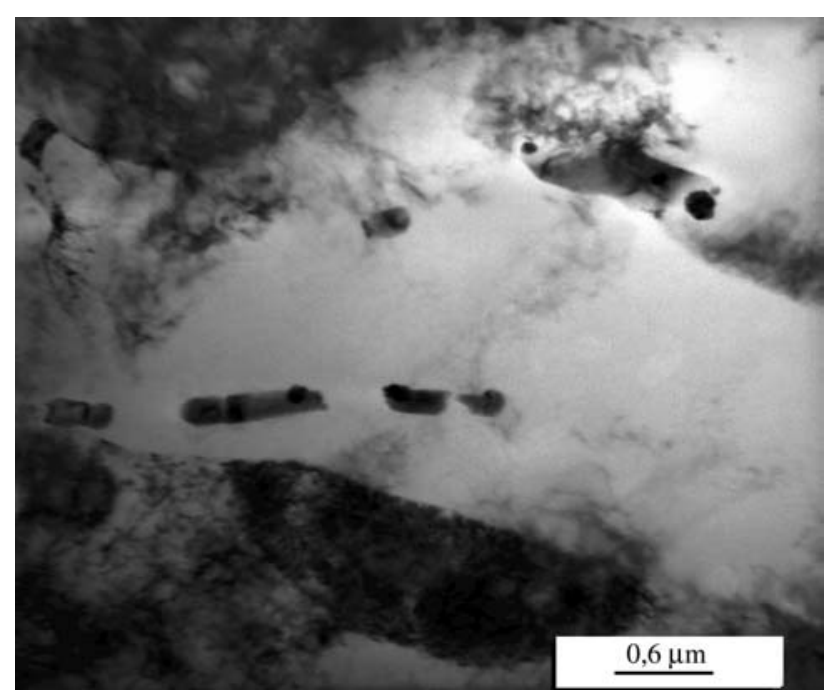

Figura 40 - Microestrutura da amostra caster revelando a presença de dispersóides, microscopia eletrônica de transmissão. Amostra afinada eletroliticamente com solução contendo ácido perclórico.

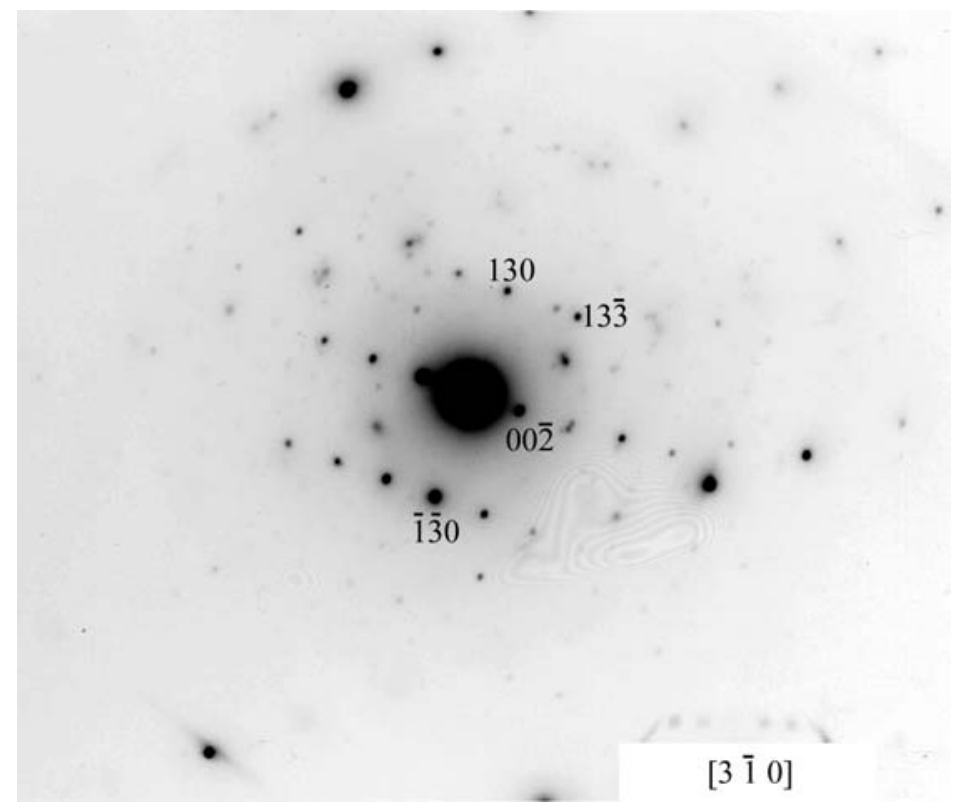

Figura 41 - Difração de elétrons de um precipitado $\mathrm{Al}_{6} \mathrm{Mn}$ encontrado na amostra caster. A direção do feixe de elétrons está indicada na micrografia. 
Na amostra laminada a quente já não se verifica a presença da estrutura dendrítica, como encontrada no caster, devido à deformação plástica ocorrida. Os precipitados possuem uma forma arredondada (Figura 44b). As frações volumétricas de precipitados ao longo da espessura foram apresentadas na Tabela 9.

As microestruturas mudam bastante ao longo da espessura nas amostras laminadas a quente. Na região central há uma heterogeneidade em relação ao tamanho de grão (Figura 45). Na região $1 / 4$ de espessura os grãos encontram-se bastante alongados no sentido da laminação (Figura 46a) e os precipitados acompanham o formato dos grãos (Figura 46b).

As partículas foram analisadas por espectroscopia de energia dispersiva (EDS). Dois precipitados de morfologias diferentes foram analisados. Pela análise dos espectros de energia dispersiva apresentados nas Figuras 48 e 49, nota-se que o precipitado da Figura 47a que apresenta formato irregular é a fase $\alpha-\mathrm{Al}(\mathrm{Mn}, \mathrm{Fe}) \mathrm{Si}$, enquanto o precipitado de formato retangular da Figura $47 \mathrm{~b}$ é a fase $\mathrm{Al}_{6}(\mathrm{Mn}, \mathrm{Fe})$, pois não apresenta $\mathrm{Si}$ em sua composição.

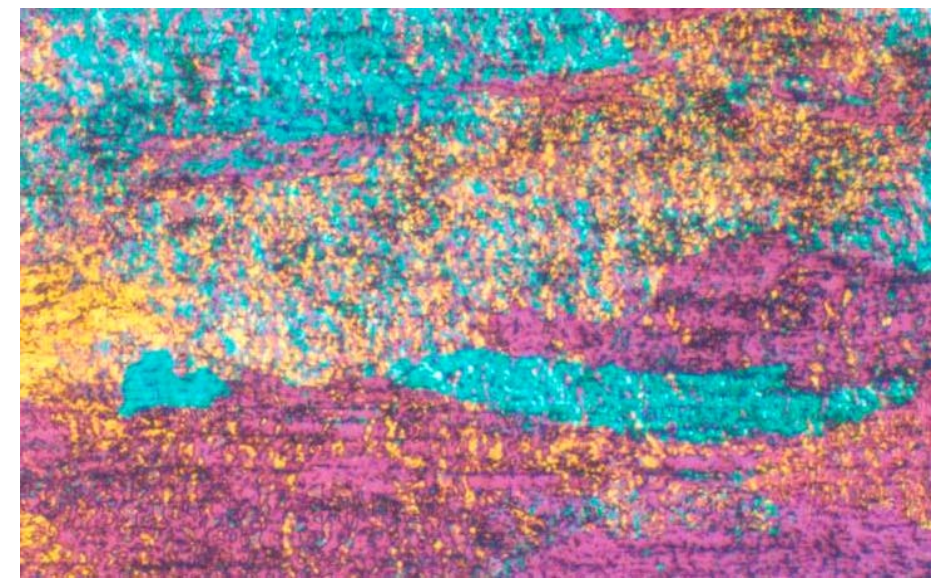

$$
200 \mu \mathrm{m}
$$

Figura 42 - Micrografia da amostra laminada a quente superfície, microscopia óptica sob luz polarizada. Amostra anodizada com solução contendo ácido fluobórico. Direção de laminação paralela à direção horizontal. 


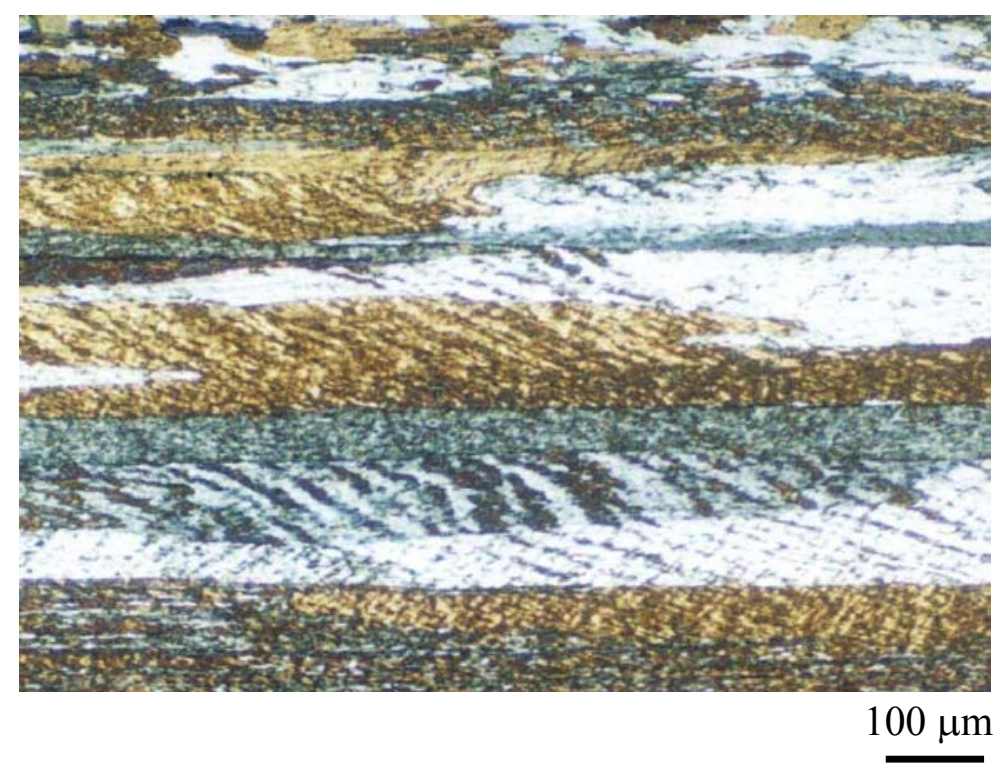

Figura 43 - Microestrutura da amostra laminada a quente na seção longitudinal, microscopia óptica sob luz polarizada. Amostra anodizada com solução contendo ácido fluobórico. Direção de laminação paralela à direção horizontal.

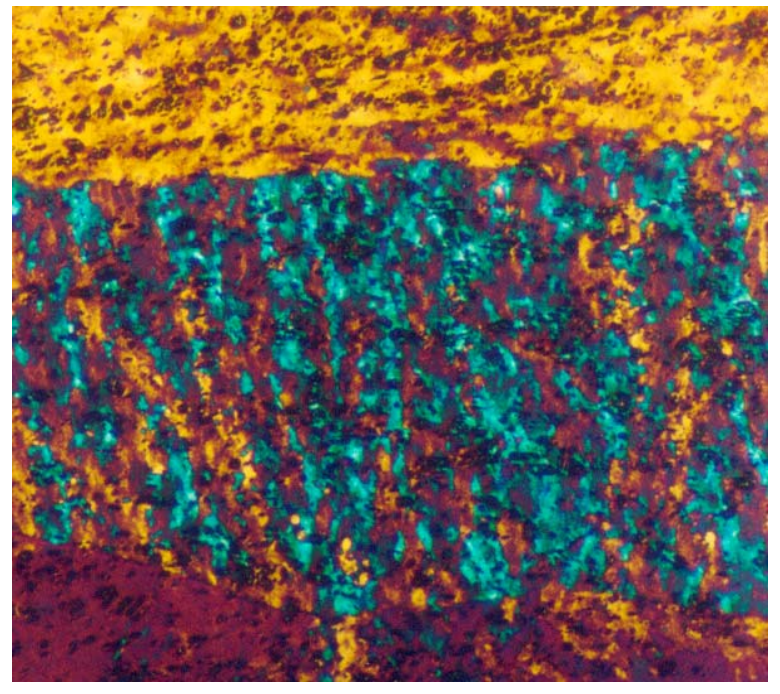

a)

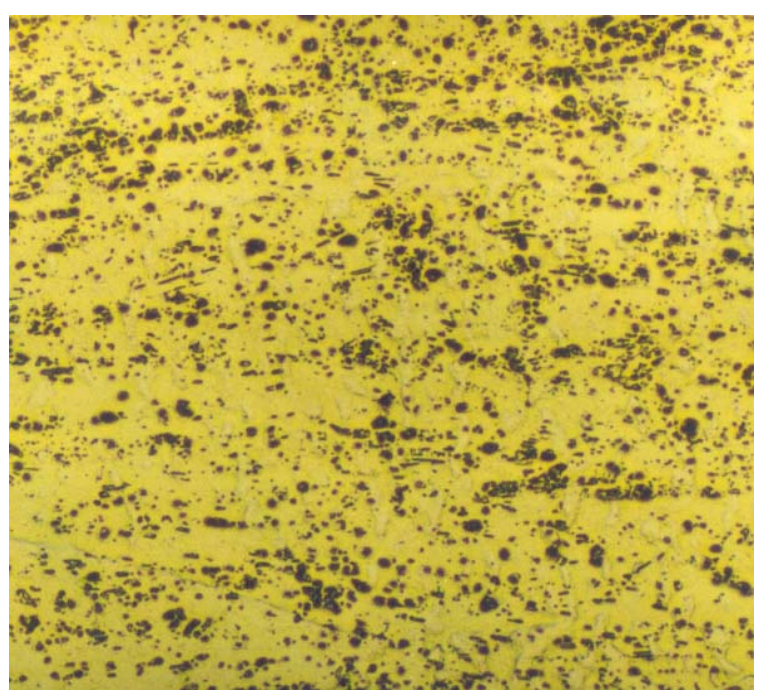

b)

$100 \mu \mathrm{m}$

Figura 44 - a)Micrografia da amostra laminada a quente superfície mostrando detalhe do interior de um grão deformado, microscopia óptica sob luz polarizada; b) mesma região mostrada em a, microscopia óptica sem luz polarizada. Amostra anodizada com solução contendo ácido fluobórico. Direção de laminação paralela à direção horizontal. 


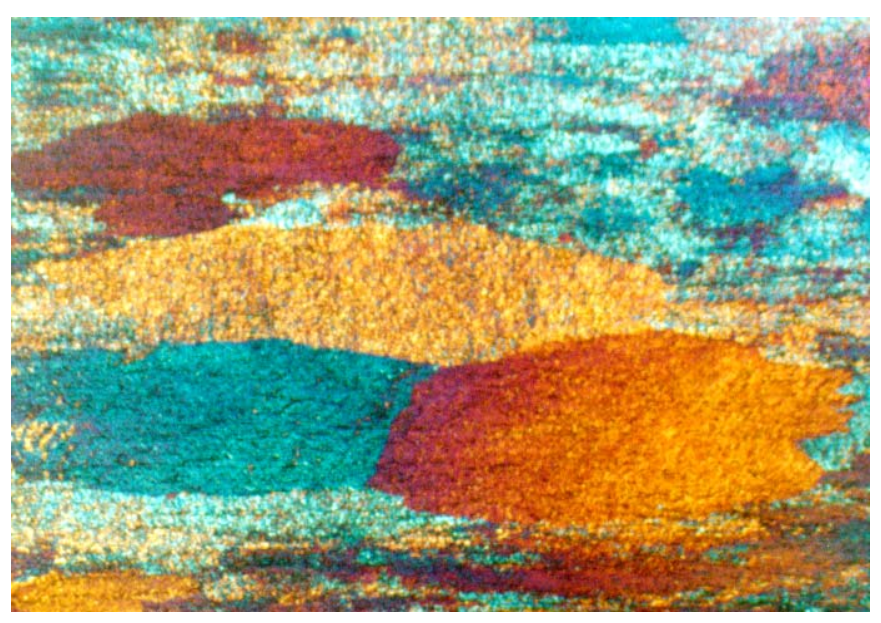

$1 \mathrm{~mm}$

Figura 45 - Micrografia da amostra laminada a quente na região 1/2 (ao longo da espessura), microscopia óptica sob luz polarizada. Amostra anodizada com solução contendo ácido fluobórico. Direção de laminação paralela à direção horizontal.

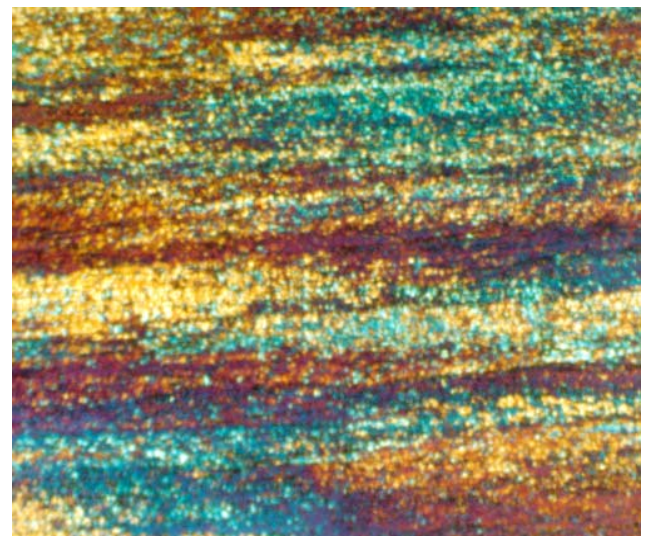

a)

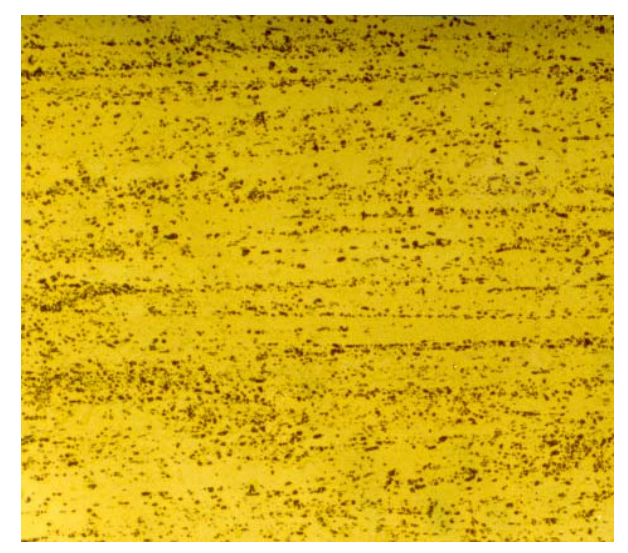

b)

Figura 46 - Micrografia da amostra laminada a quente na região $1 \frac{1}{4}$ da superfície (ao longo da espessura), microscopia óptica sob luz polarizada; b) Micrografia da amostra laminada a quente região $1 / 4$ da superfície, mesma região mostrada em a, microscopia óptica sem luz polarizada. Amostra anodizada com solução contendo ácido fluobórico. Direção de laminação paralela à direção horizontal. 


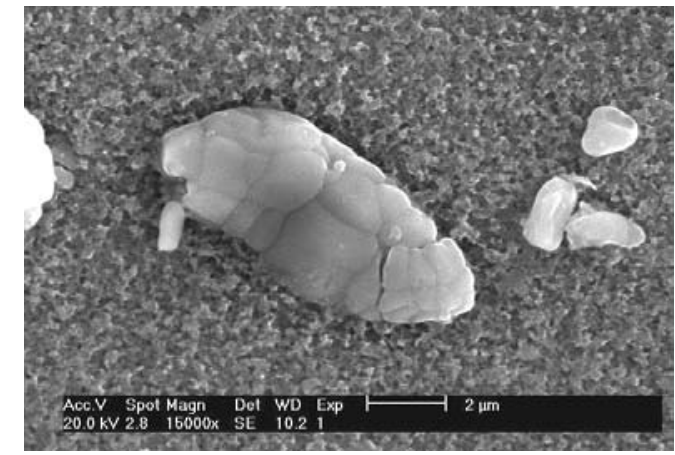

a)

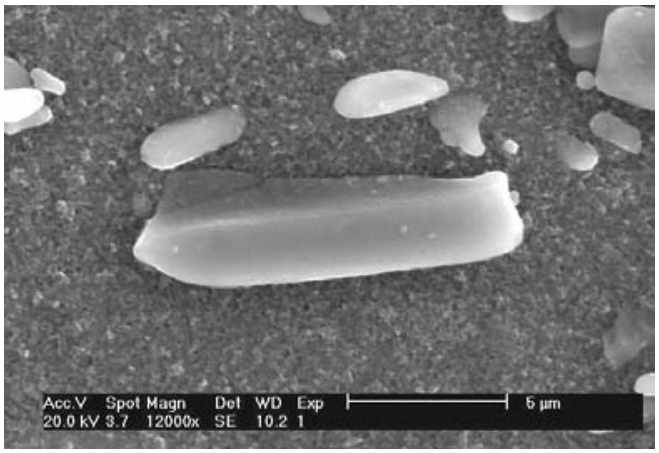

b)

Figura 47 - Precipitados encontrados na amostra laminada a quente, microscopia eletrônica de varredura, elétrons secundários. Amostra atacada com solução contendo ácido fluorídrico.

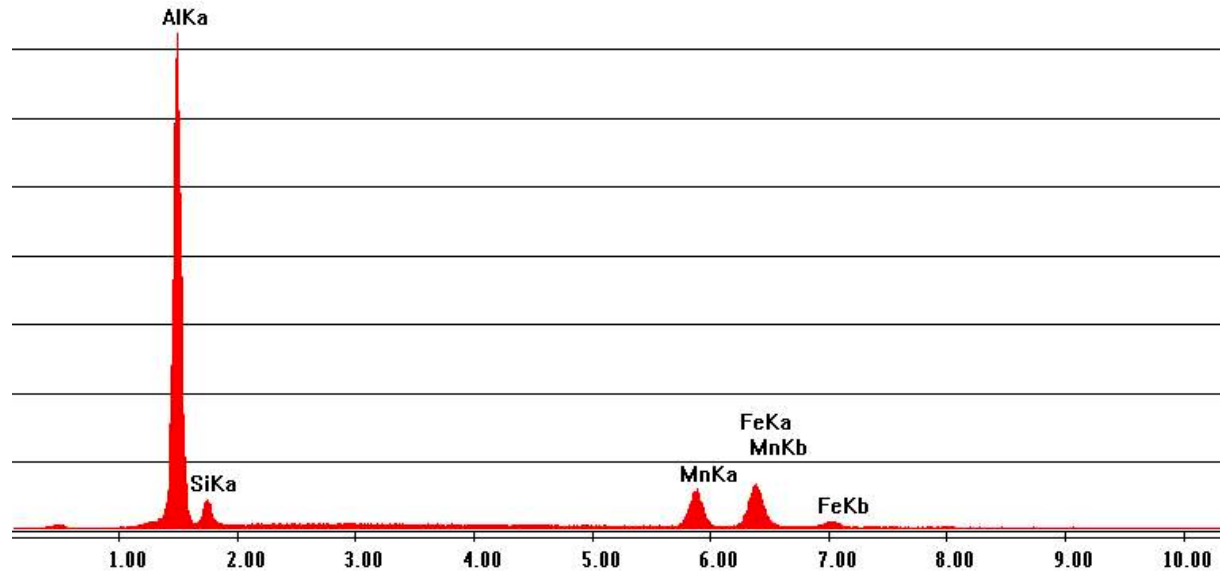

Figura 48 - Espectro (EDS) do precipitado da Figura 47a.

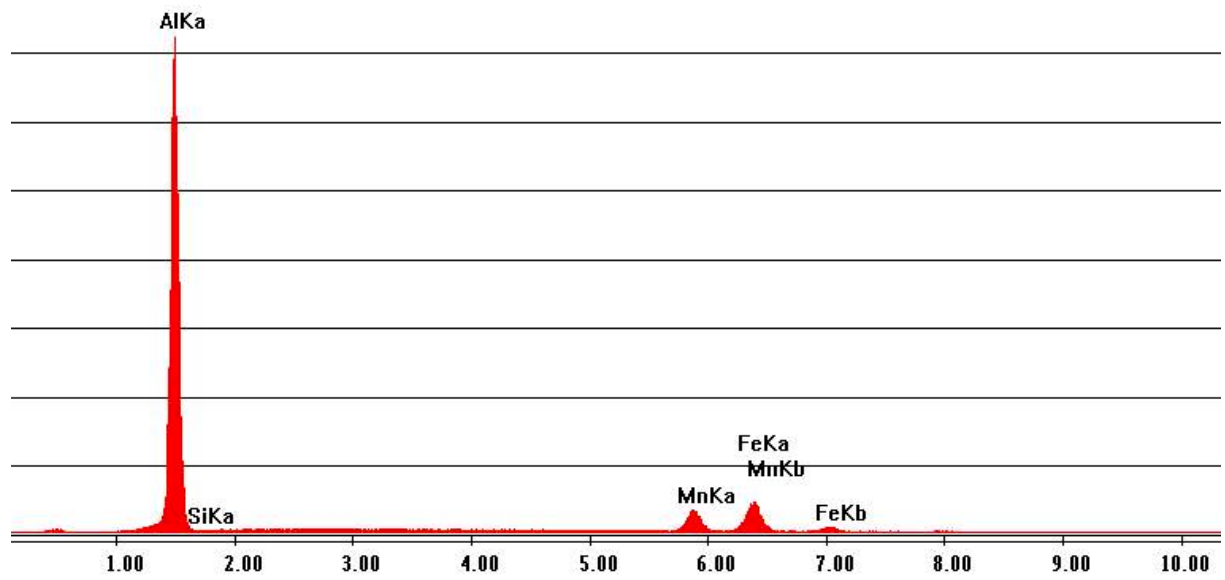

Figura 49 - Espectro (EDS) do precipitado da Figura 47b. 
As Figuras 50 e 51 revelam a presença de subgrãos na amostra laminada a quente, as discordâncias são formadas durante deformação a quente e se rearranjam em subgrãos Há a presença de pequenas partículas arredondadas presentes nos subcontornos. Nestas Figuras também se pode observar a presença de pequenas partículas, da ordem $0,2 \mu \mathrm{m}$, encontrados no interior do grão e em subcontornos. Nota-se discordâncias ao redor de dispersóides.

O alumínio puro tem energia de defeito de empilhamento (EDE) acima de 150 $\mathrm{mJ} / \mathrm{m}^{2}$, ou seja, consideravelmente alta, quando comparada [Bever et al, 1973] com outros metais e ligas com estrutura cristalina $\mathrm{CFC}$, tais como $\mathrm{Ag}, \mathrm{Cu}, \mathrm{Au}, \mathrm{Pb}, \mathrm{Pt}$, latões, bronzes e aços inoxidáveis austeníticos. O alumínio é, portanto, um metal CFC que apresenta elevada energia de defeito de empilhamento, de modo que na deformação a frio, uma estrutura celular de discordâncias é formada para deformações maiores de 0,1\%. A natureza destes desenvolvimentos microestruturais tem sido alvo de estudos e sabe-se que as células de discordâncias são regiões de material de densidade de discordâncias muito baixas separadas entre si por paredes de célula, que são emaranhados de discordâncias, de modo que cada célula é separada das vizinhas por pequena desorientação cristalográfica. A diminuição da energia de defeito de empilhamento do metal faz diminuir a tendência à formação de células de discordâncias. O tamanho médio das células de discordâncias diminui e a desorientação média entre células aumenta com o aumento da deformação.

Há uma diferença que caracteriza o trabalho a quente, em relação ao trabalho a frio: a ocorrência da recuperação concomitantemente ao encruamento. Desta forma, na deformação a quente, o fenômeno do encruamento, caracterizado pelo aumento da densidade de discordâncias do material, é acompanhado pelos mecanismos de recuperação dinâmica.

Na Figura 52 encontra-se uma difração de elétrons da matriz alumínio, vê-se que há outros pontos difratados além dos pontos da matriz que pertencem ao precipitado. Pela dificuldade de indexação não foi possível identificar o precipitado, somente a matriz foi indexada. 


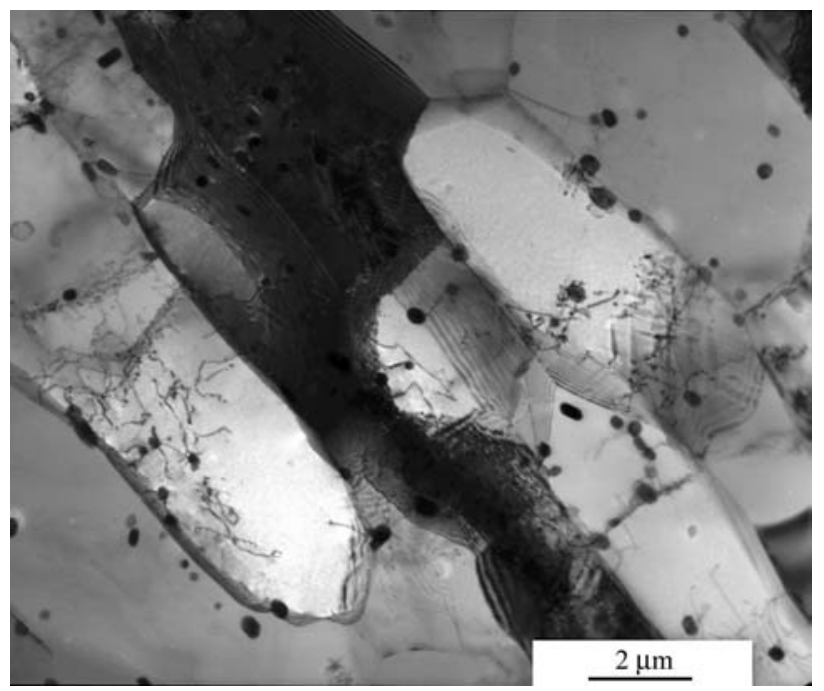

Figura 50 - Subestrutura de liga laminada a quente mostrando subgrãos desenvolvidos que contêm alta densidade de discordâncias em seus interiores, microscopia eletrônica de transmissão. Amostra polida eletroliticamente com solução contendo ácido perclórico.

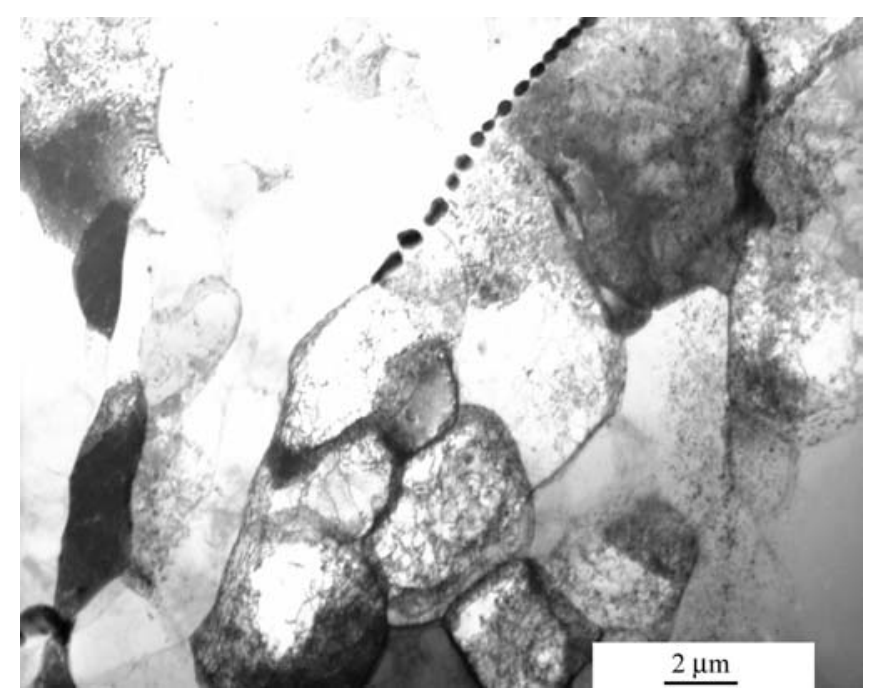

Figura 51 - Micrografia da amostra laminada a quente mostrando estrutura de subgrãos e presença de dispersóides, microscopia eletrônica de transmissão. Amostra polida eletroliticamente com solução contendo ácido perclórico. 


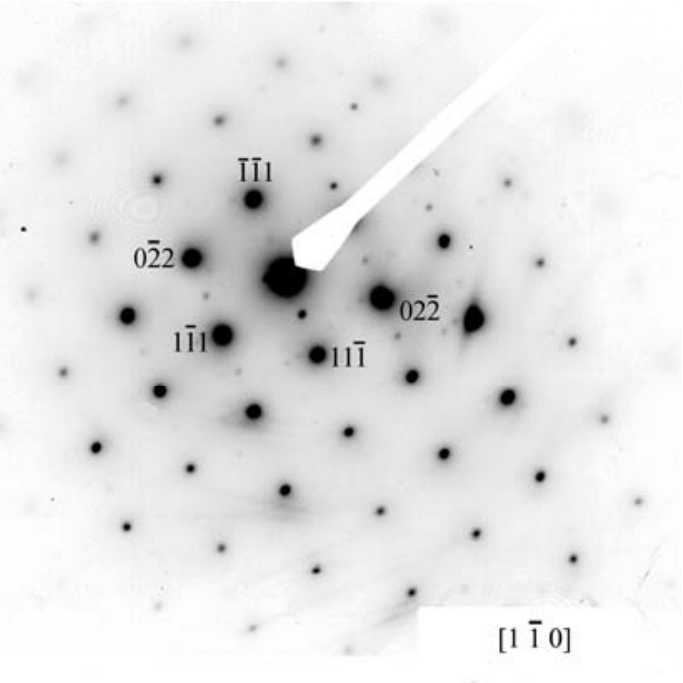

Figura 52 - Difração de elétrons da matriz alumínio, na amostra laminada a quente. A direção do feixe de elétrons é indicada na micrografia. 


\subsection{Análise comparativa de textura resultante dos processos caster e laminada a quente}

As texturas das chapas foram analisadas ao longo da espessura (superfície, $1 / 4$ da espessura e centro) pela técnica difração de raios X. Uma descrição mais completa da textura pode ser obtida com o auxílio da função distribuição de orientação (FDO) dos grãos. Estas funções especificam a freqüência de ocorrência de determinadas orientações em um espaço tridimensional. Este espaço é definido por três ângulos de Euler: $\varphi_{1}, \Phi$, $\varphi_{2}$. A FDO é calculada através das figuras de pólos obtidas pela difração de raios X. A Figura 53 mostra a localização no espaço de Euler das componentes de textura mais importantes da laminação de metais CFC. Estas componentes compreendem a fibra $\alpha$ entre "Goss" $\{011\}<100>$ e latão ("Brass") $\{110\}<1 \overline{1} 2>$ e a fibra $\beta$ entre latão e cobre $\{112\}<11 \overline{1}>$, passando pela componente do tipo $\mathrm{S}\{123\}<63 \overline{4}>$.

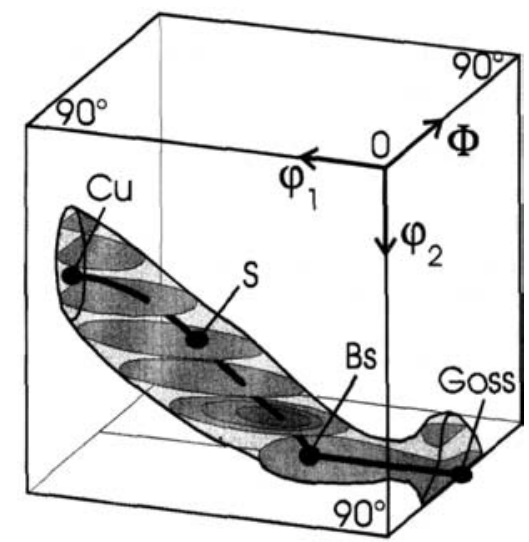

Figura 53 - Componentes de textura de laminação de metais CFC no espaço de Euler em 3D: a fibra $\beta$ entre a componente cobre e latão ("Brass") e a fibra $\alpha$ entre a componente do tipo latão e Goss [Maurice, 1997].

$\mathrm{Na}$ região da superfície da caster foi observada a presença da componente $\{001\}<110>\left(\varphi_{1}=45^{\circ}, \phi=0^{\circ}, \varphi_{2}=0^{\circ}\right)$, conhecida como cubo rodado com uma intensidade $\mathrm{f}(\mathrm{g})$ igual a 27,2 . Na região central foi verificada a presença de três 
componentes: tipo latão $\left(\varphi_{1}=35^{\circ}, \phi=45^{\circ}, \varphi_{2}=0^{\circ}\right)$, de maior intensidade $\mathrm{f}(\mathrm{g})=13,6$, tipo $\mathrm{S}\left(\varphi_{1}=59^{\circ}, \phi=34^{\circ}, \varphi_{2}=65^{\circ}\right) \operatorname{com} \mathrm{f}(\mathrm{g})=11,7$ e a tipo cobre $\left(\varphi_{1}=90^{\circ}, \phi=30^{\circ}, \varphi_{2}\right.$ $\left.=45^{\circ}\right) \operatorname{com} \mathrm{f}(\mathrm{g})=9,7$. Na região $1 / 4$ de espessura nota-se a presença da componente do tipo latão, com $\mathrm{f}(\mathrm{g})=10,3$. A componente Goss $\left(\varphi_{1}=0^{\circ}, \phi=45^{\circ}, \varphi_{2}=0^{\circ}\right)$ que aparece na FDO na Figura 56 está relacionada ao fenômeno ghost, pois as FP's foram analisadas e esta componente não foi encontrada. Mas em estudos feitos por Singh [1998] há um aumento em intensidade da componente Goss da superfície ao centro que pode ser atribuído às menores taxas de resfriamento durante e depois da laminação a quente.

Quando se comparam os resultados de textura da amostra caster ao longo de sua espessura, observa-se que a textura no centro da amostra é semelhante a textura de laminação a frio, considerando-se componentes encontradas e intensidades. A componente cubo rodado $\{001\}<110>$ encontrada na superfície da amostra caster não foi encontrada após laminação a frio. Durante laminação, a textura cubo rodado se transforma em textura tipo latão, cobre e S [Zhang et al, 2002]. 


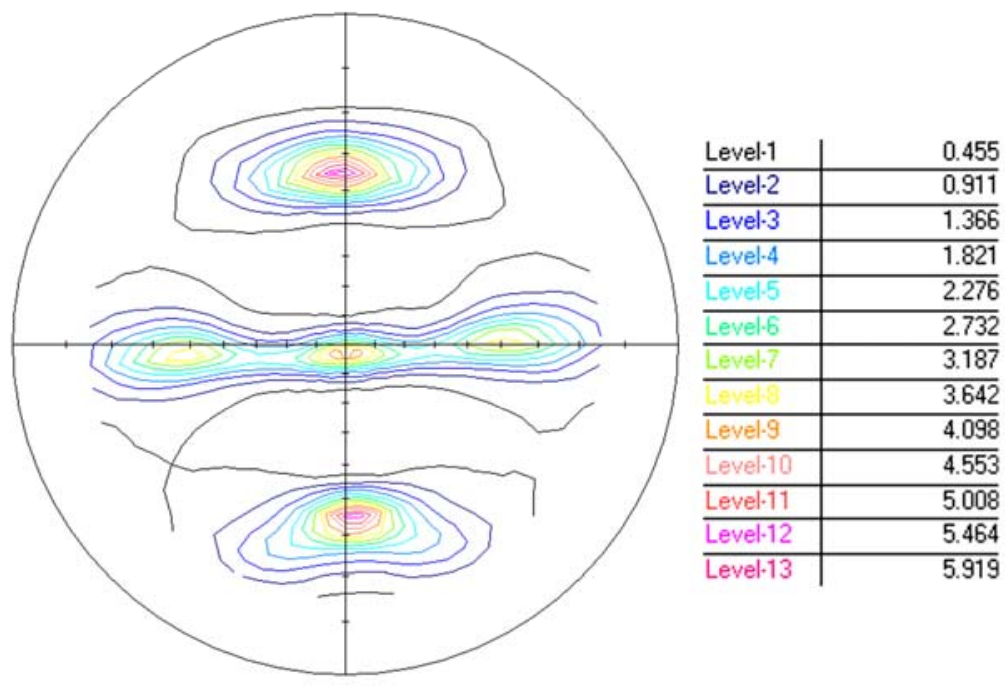

a)

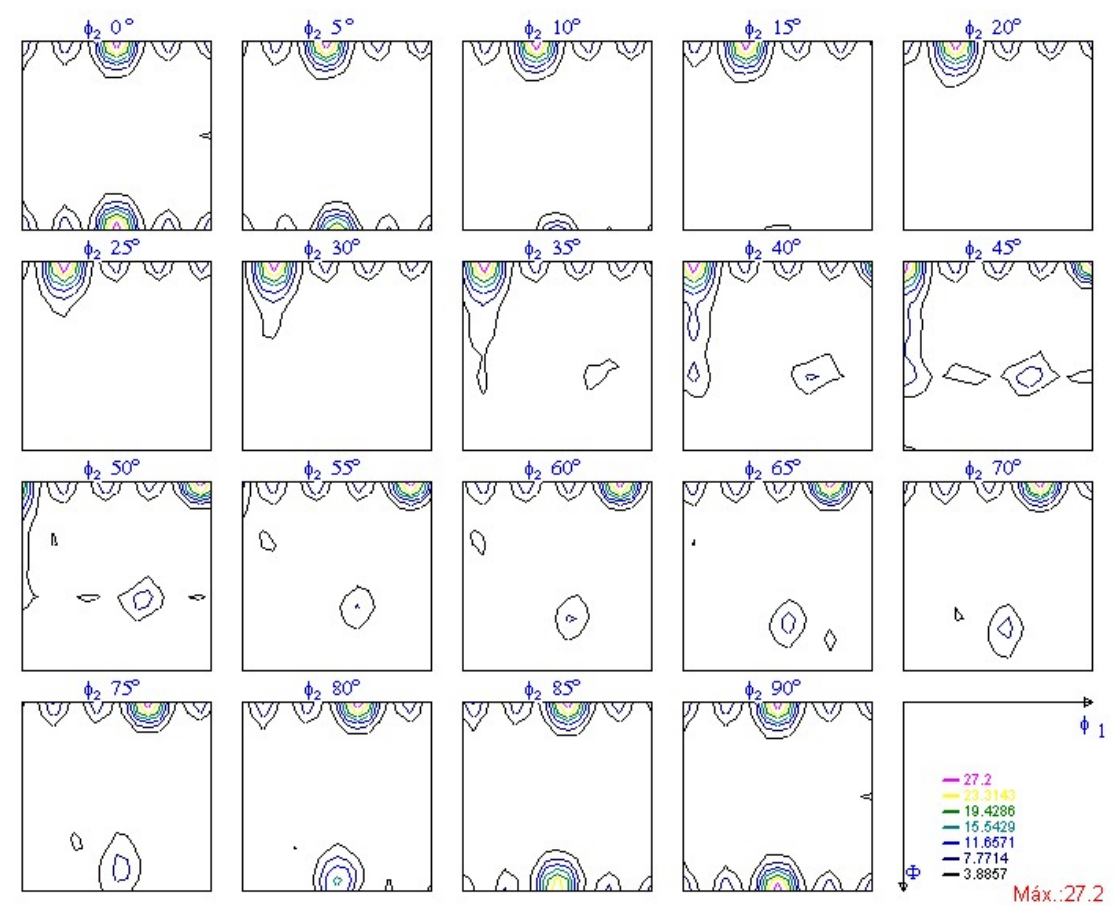

b)

Figura 54 - a) FP 111 obtida por difração de raios X da amostra caster na superfície; b) FDO (difração de raios X) da amostra caster na superfície. 


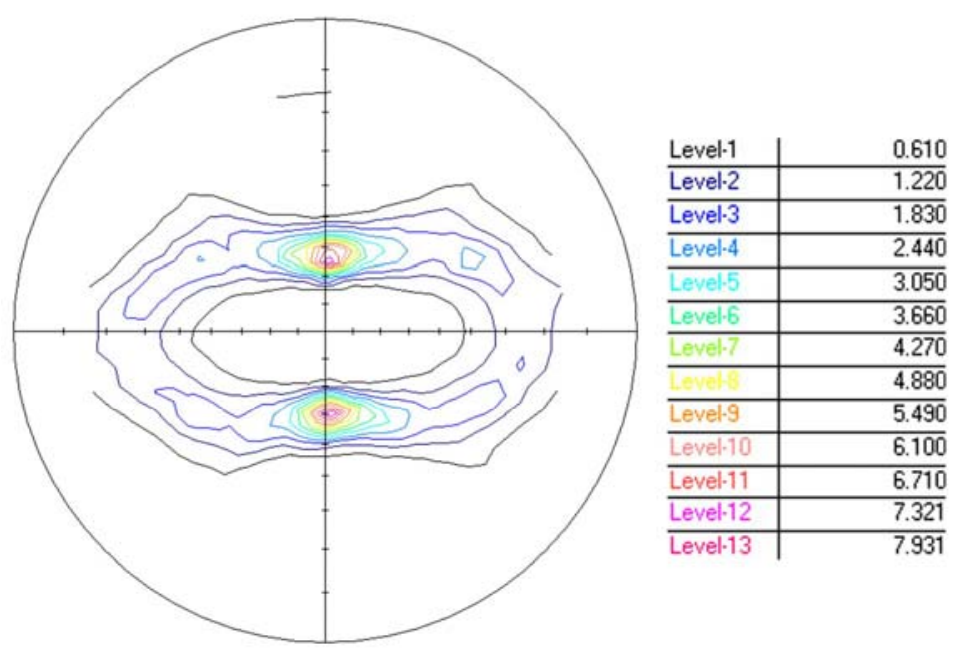

a)
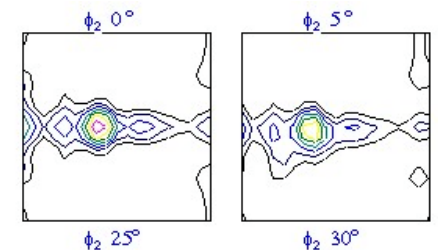

$\phi_{2} 10^{\circ}$
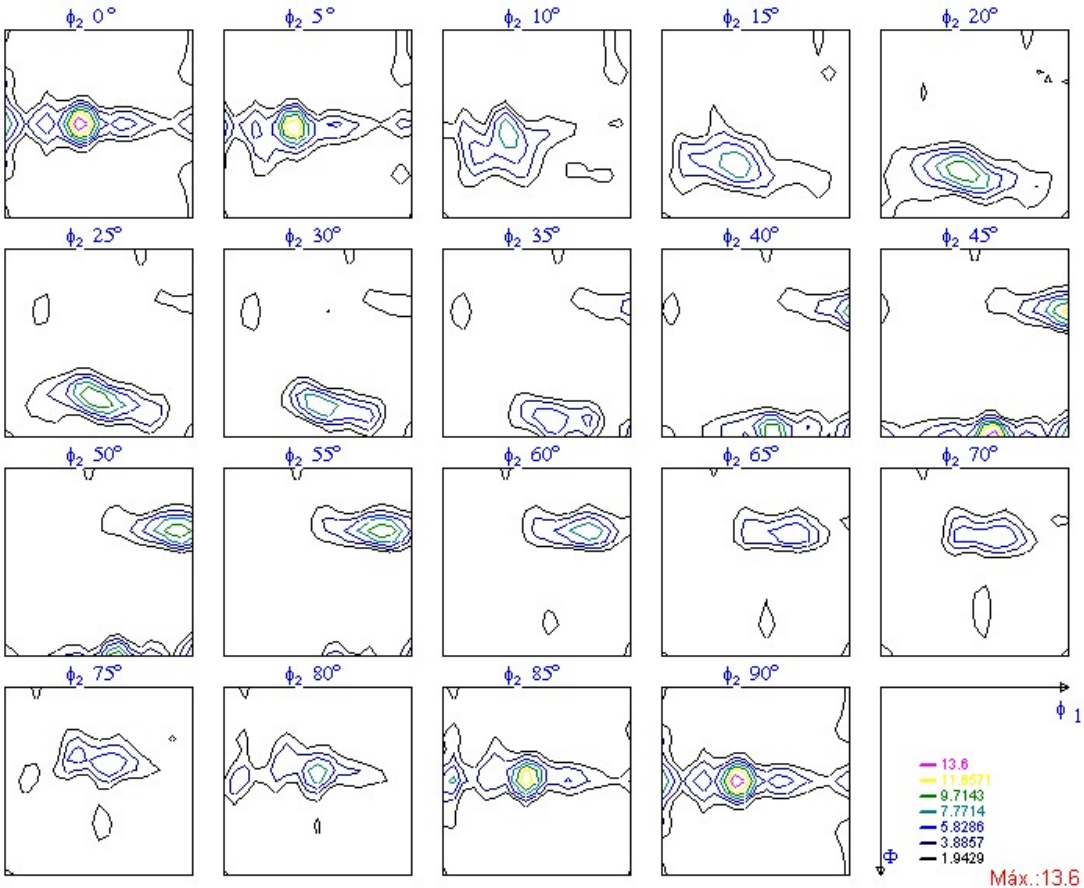

b)

Figura 55 - a) FP 111 obtida por difração de raios $X$ da amostra caster na seção $1 / 2$ da espessura; b) FDO (difração de raios X) da região central ( $1 / 2$ da espessura ) da amostra caster. 


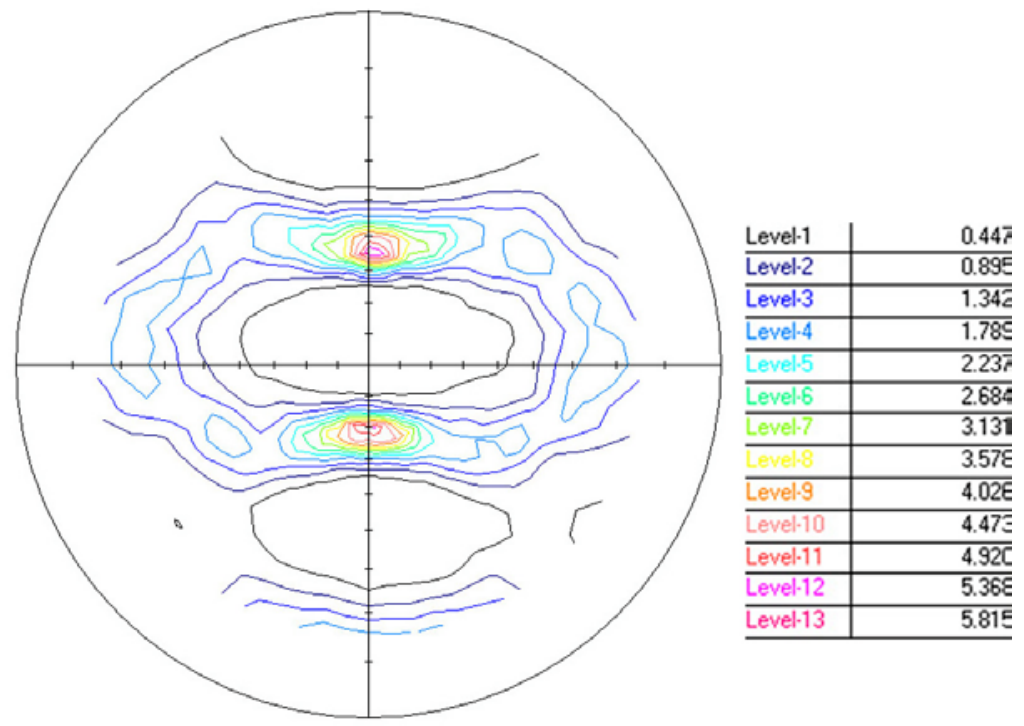

a)
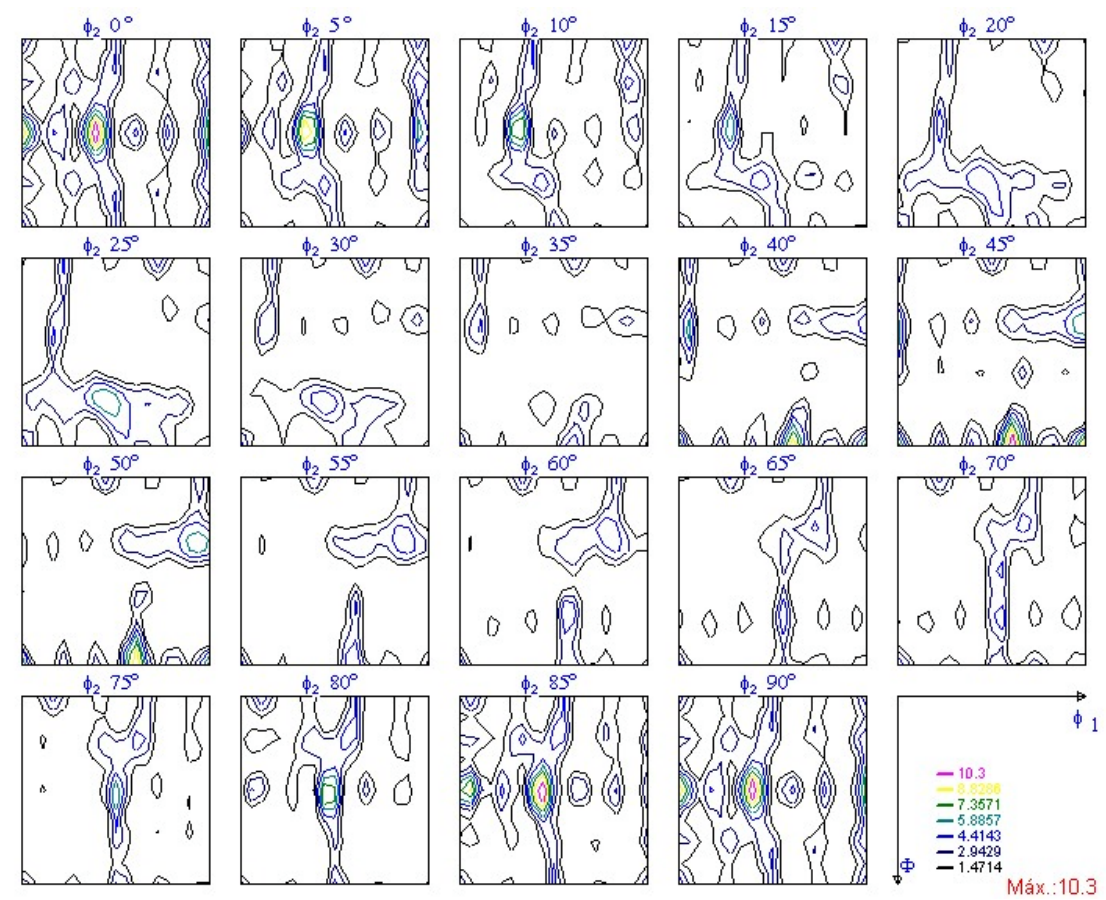

b)

Figura 56 - a) FP 111 obtida por difração de raios $X$ da amostra caster na seção 1/4 da espessura; b) FDO (difração de raios X) da região 1/4 da espessura da amostra caster. 
Análises da microtextura e mesotextura também foram feitas para caracterização inicial da amostra. Na Figura 57 encontram-se medidas de mesotextura indicando a natureza dos contornos. Os contornos marcados em amarelo indicam contornos de alto ângulo $\left(\psi>15^{\circ}\right)$ enquanto os contornos marcados em preto indicam contornos de baixo ângulo $\left(\psi<15^{\circ}\right)$. Nota-se que há uma alta fração de contornos de baixo ângulo na região fortemente texturizada.

$\mathrm{Na}$ mesma amostra foram feitas dez varreduras em diferentes regiões e cada varredura foi feita com o mesmo número de pontos. As informações destas dez regiões foram somadas para se poder ter uma medida mais próxima da macrotextura.

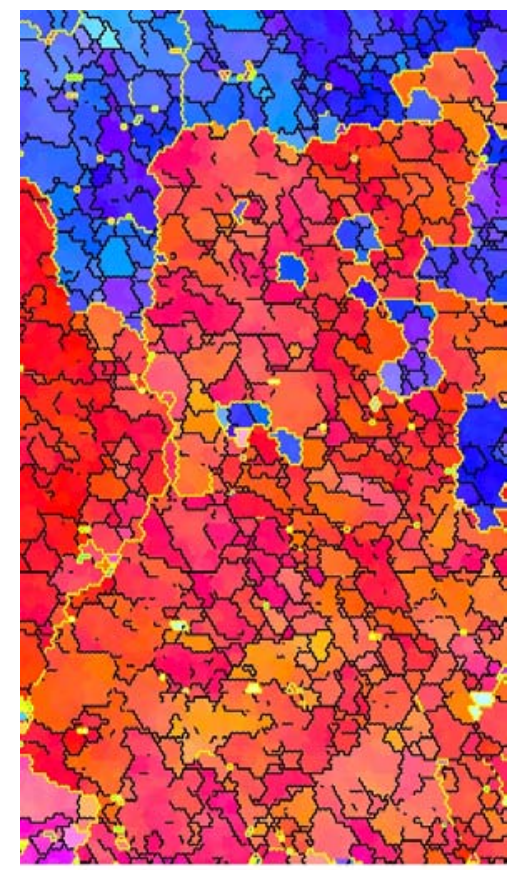

$20.00 \mu \mathrm{m}=20$ steps

$$
-\frac{\text { Min }}{0^{\circ}} \frac{\text { Max }}{15^{\circ}} \frac{\text { Fraçăo }}{0.802}
$$
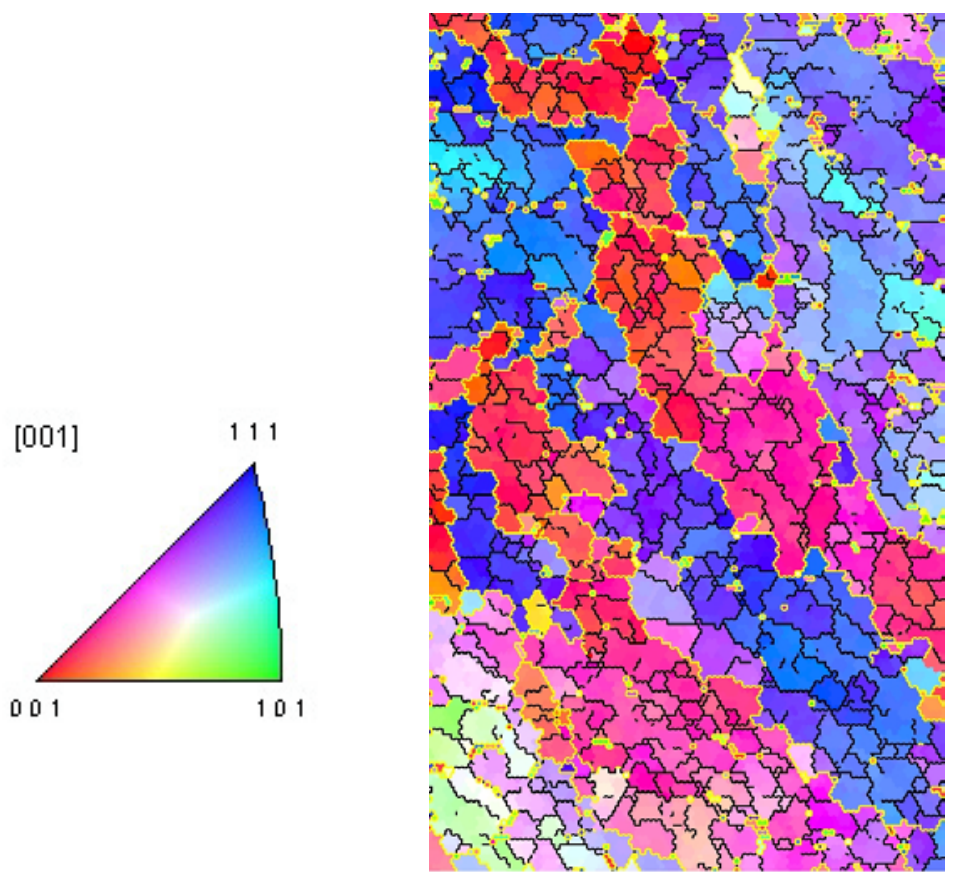

$20.00 \mu \mathrm{m}=20$ steps

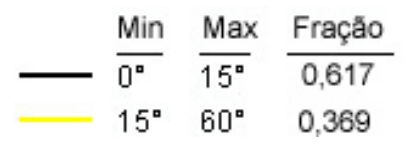

Figura 57 - Mapeamento de orientações da superfície do caster (EBSD), direção de laminação paralela à direção vertical. 
A análise da figura de pólo discreta permite avaliar a simetria e o espalhamento em torno das componentes principais, como apresenta a Figura 58.

A representação em curvas de níveis é possível utilizando o algorítmo de cálculo disponível no programa, porém é necessário definir uma simetria para a amostra. Teoricamente independente da imposição da simetria triclínica ou ortorrômbica os resultados serão semelhantes, desde que a amostra apresente simetria. Para amostras que apresentam intensidade de textura relativamente alta, a imposição da simetria triclínica ou ortorrômbica não acarreta diferenças significativas.

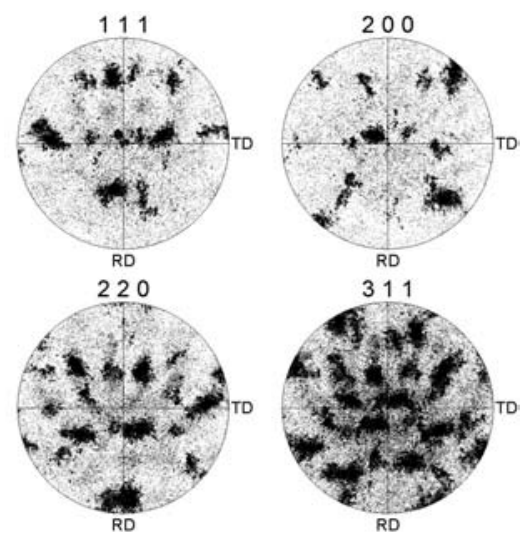

Figura 58 - Figuras de pólo discretas da superfície do caster (EBSD). 


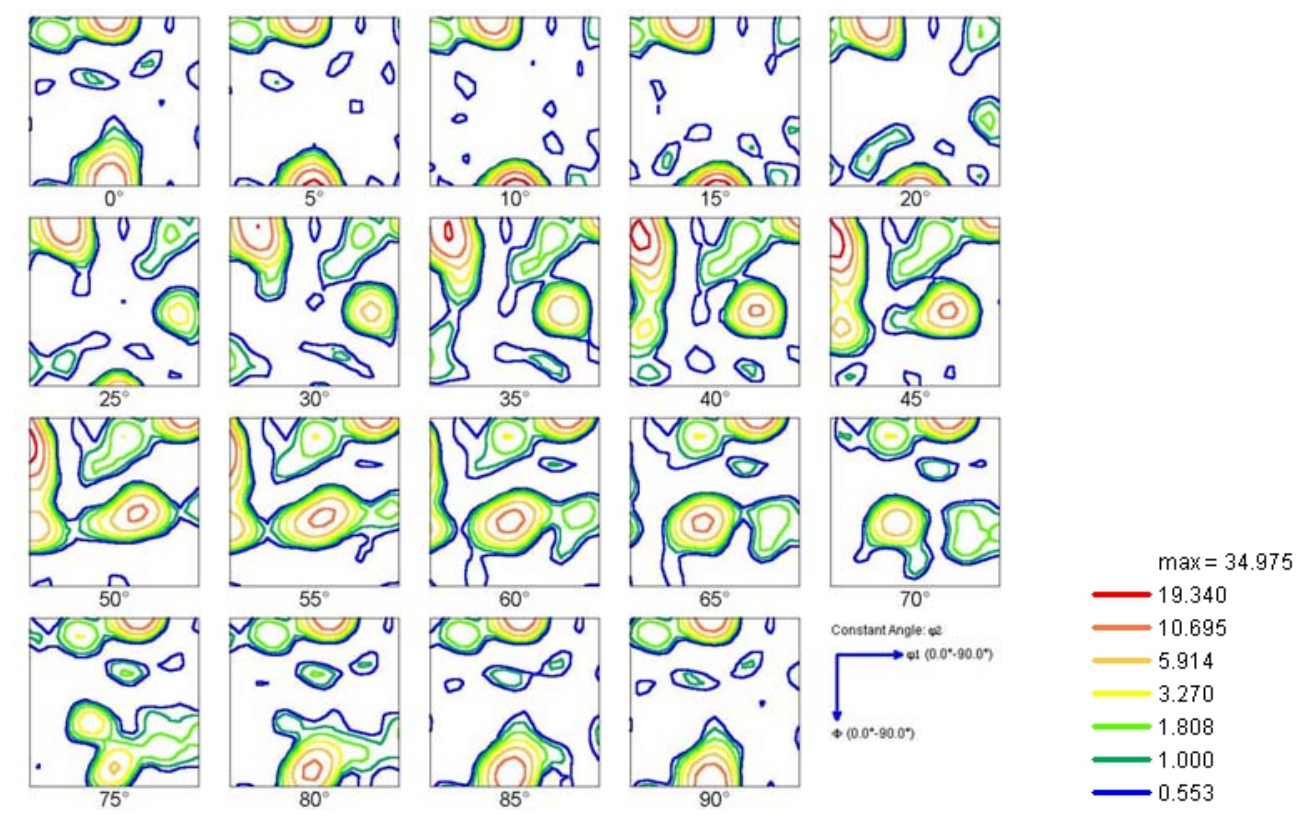

Figura 59 - FDO (EBSD) da superfície do caster com simetria triclínica.

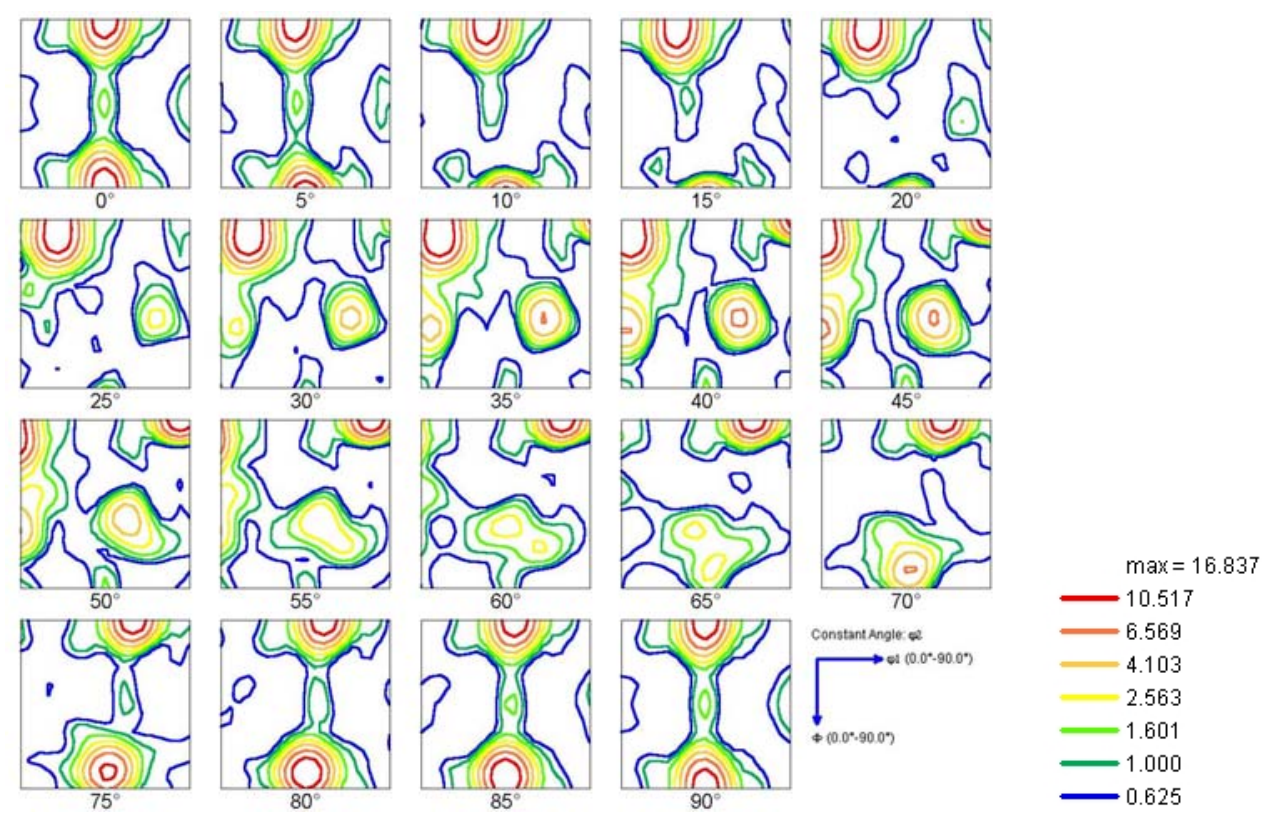

Figura 60 - FDO (EBSD) da superfície do caster com simetria ortorrômbica. 
A imposição da simetria ortorrômbica de um modo geral causou um alargamento nos picos das principais orientações para FDO, como mostram as Figuras 59 e 60.

A textura da chapa laminada a quente também foi analisada ao longo da espessura (superfície, $1 / 4$ da espessura e centro). Na superfície da amostra laminada a quente, a FDO revela a presença da componente $\{001\}<110>$, conhecida como cubo rodado (rotated cube) como mostra a Figura 61. Esta componente aparece com uma intensidade igual a 28. Daaland e Nes [1996] encontraram a presença forte da componente $\{001\}<110>$ na região da superfície de uma placa laminada a quente de uma liga Al1Mn0,5Mg e que se estende até $1 / 3$ de espessura da placa. No centro da amostra laminada a quente a FDO apresentada na Figura 62 revela a presença da mesma componente encontrada na superfície da amostra, a componente cubo rodado. A Figura 63 mostra a FDO da seção 1/4 de espessura da amostra laminada a quente onde verificase a presença da componente $\{011\}<21 \overline{1}>$, tipo latão, de intensidade 15,6 .

Lee et al [1993] propuseram que a subdivisão de orientações dentro dos grãos de policristais favorecem a formação da componente tipo latão que ocorre freqüentemente durante laminação a quente. 


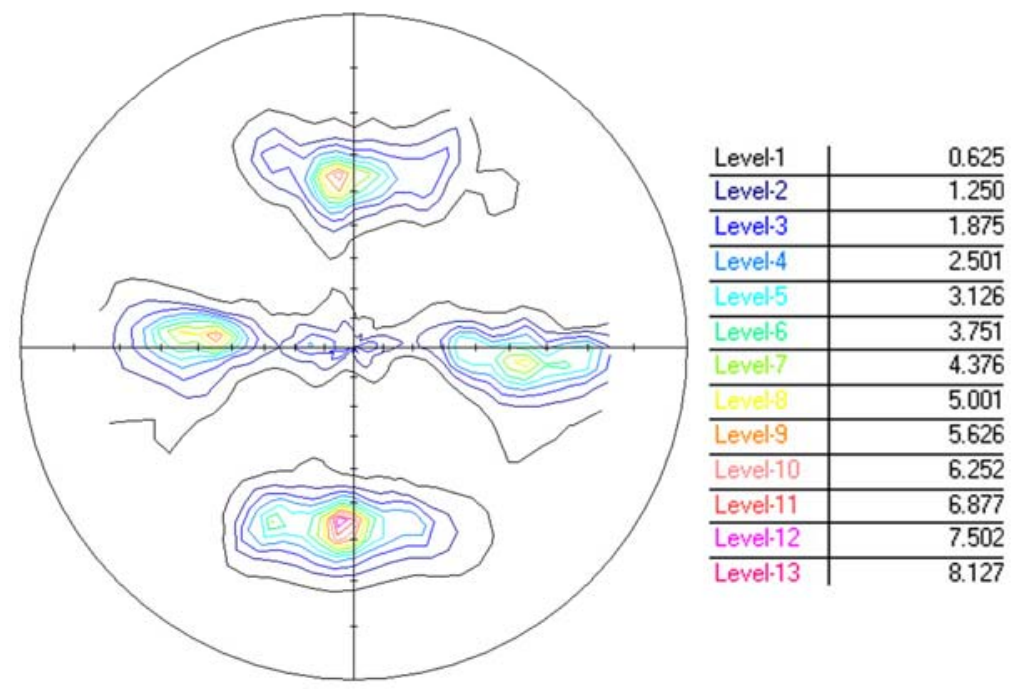

a)

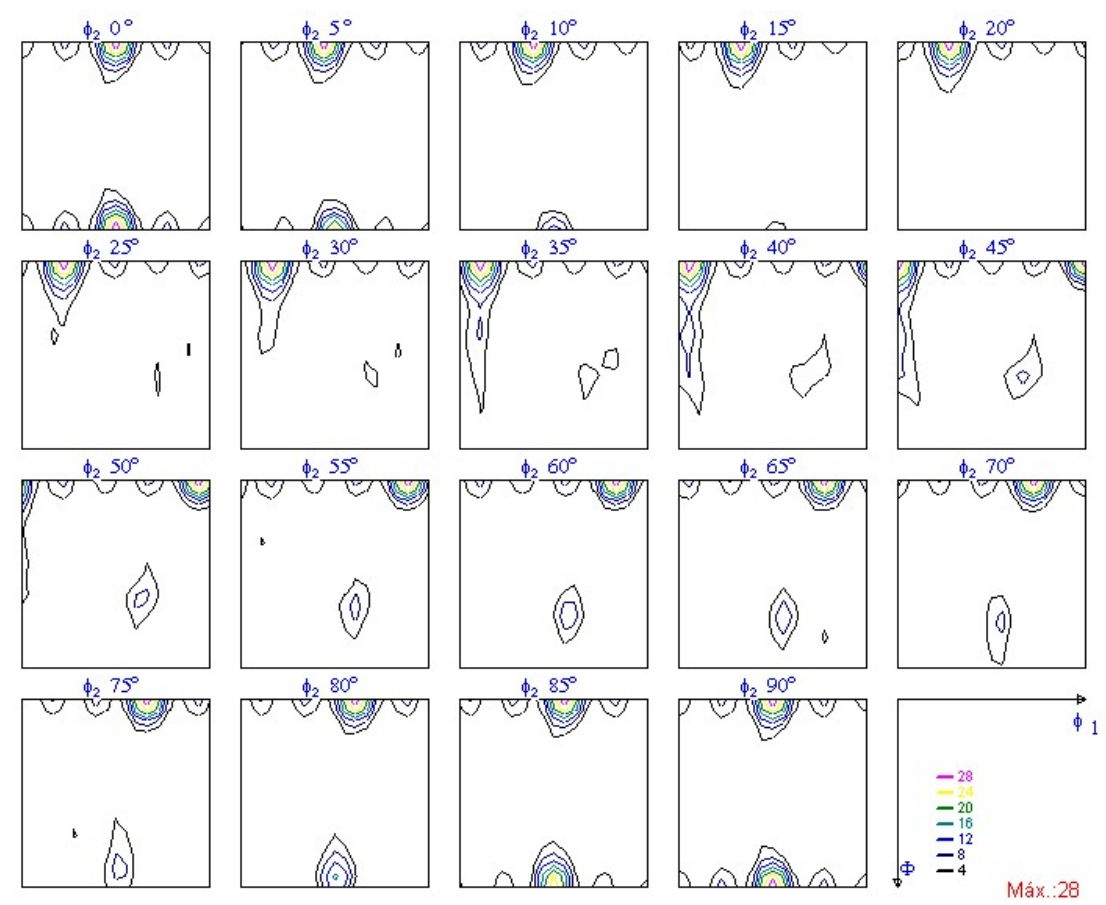

b)

Figura 61 - a) FP 111 obtida por difração de raios X da amostra laminada a quente na superfície; b) FDO (difração de raios X) da superfície da amostra laminada a quente. 


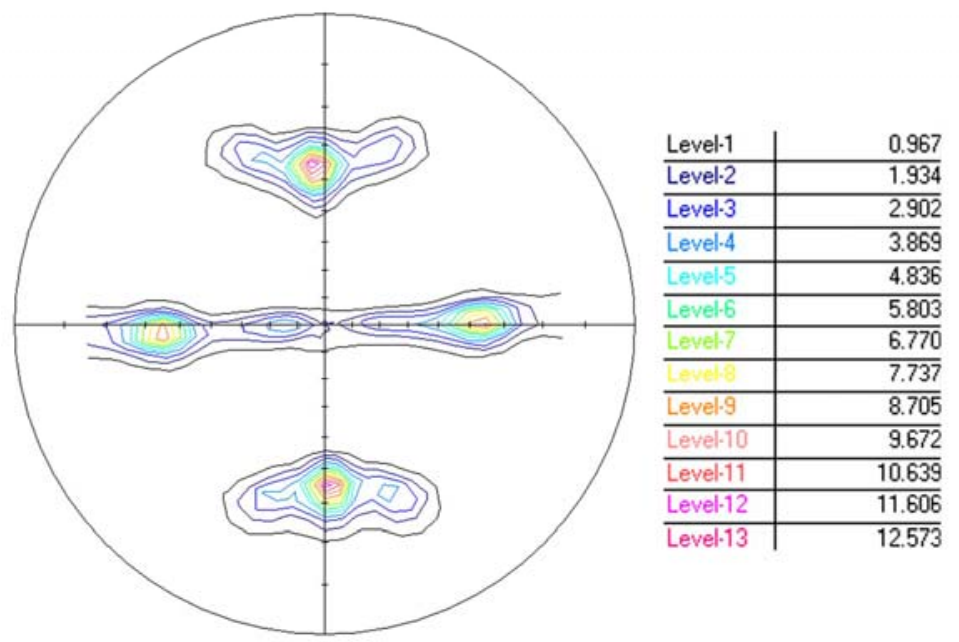

a)

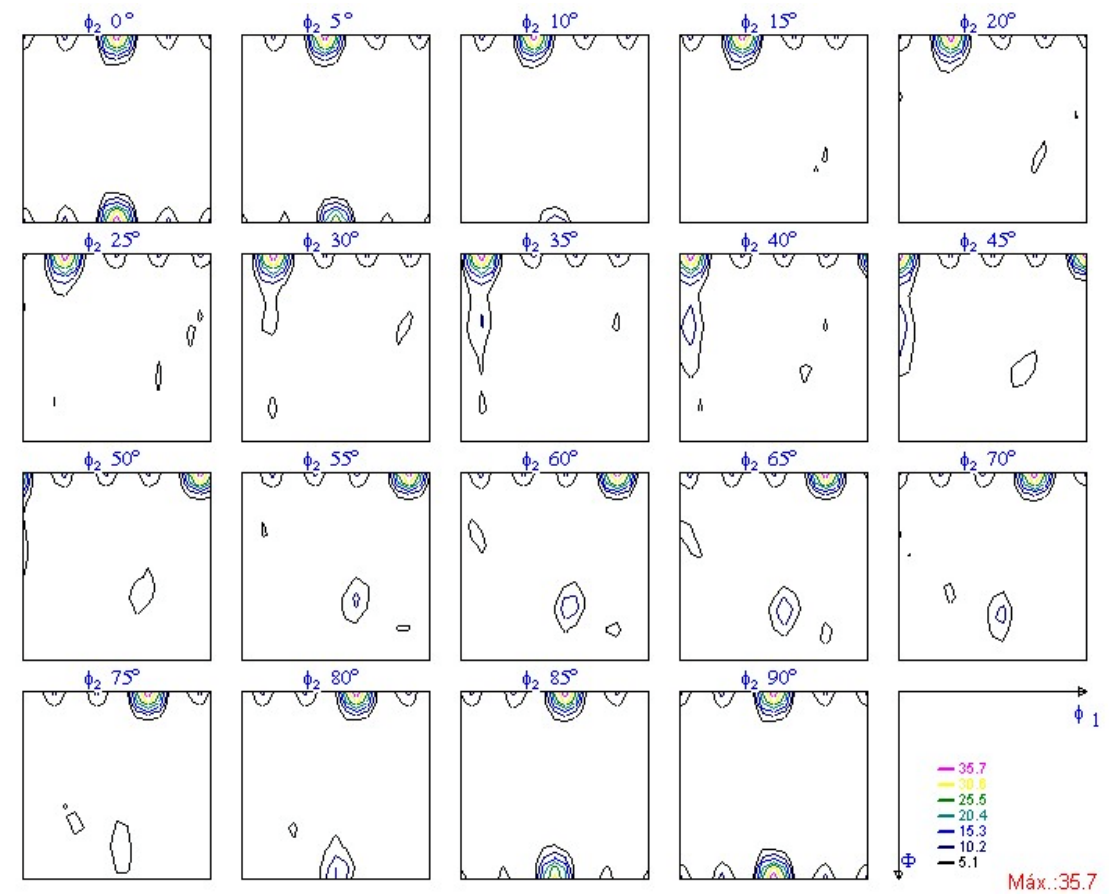

b)

Figura 62 - a) FP 111 obtida por difração de raios $X$ da amostra laminada a quente na região $1 / 2$ de espessura; b) FDO (difração de raios $\mathrm{X}$ ) na região $1 / 2$ da espessura da amostra laminada a quente. 


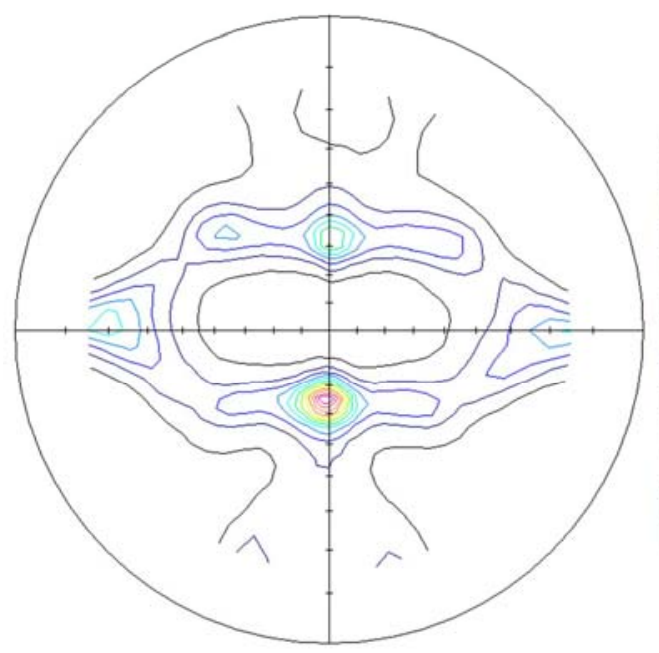

\begin{tabular}{c|c} 
Level-1 & 0.601 \\
\hline Level-2 & 1.201 \\
\hline Level-3 & 1.802 \\
\hline Level-4 & 2.402 \\
\hline Level-5 & 3.003 \\
\hline Level-5 & 3.603 \\
\hline Level-7 & 4.204 \\
\hline & 4.804 \\
\hline Level-9 & 5.405 \\
\hline Level-10 & 6.005 \\
\hline Level-11 & 6.606 \\
\hline Level-12 & 7.206 \\
\hline Level-13 & 7.807
\end{tabular}

a)
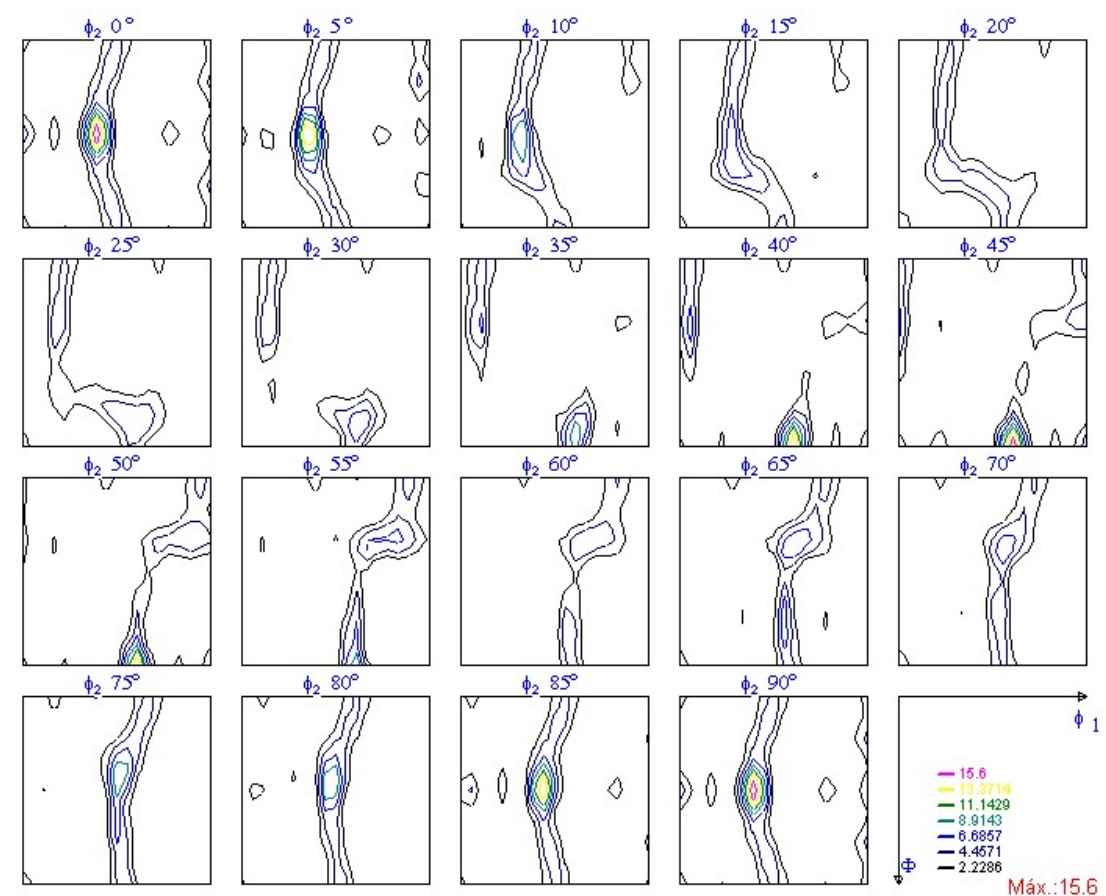

b)

Figura 63 - a) FP 111 obtida por difração de raios $X$ da amostra laminada a quente na região 1/4 da espessura; b) FDO (difração de raios X) na região $1 / 4$ da espessura da amostra laminada a quente. 
Na Figura 64 são apresentadas medidas de mesotextura indicando a natureza dos contornos. Nota-se também a presença de alta fração de contornos de baixo ângulo na microestrutura.

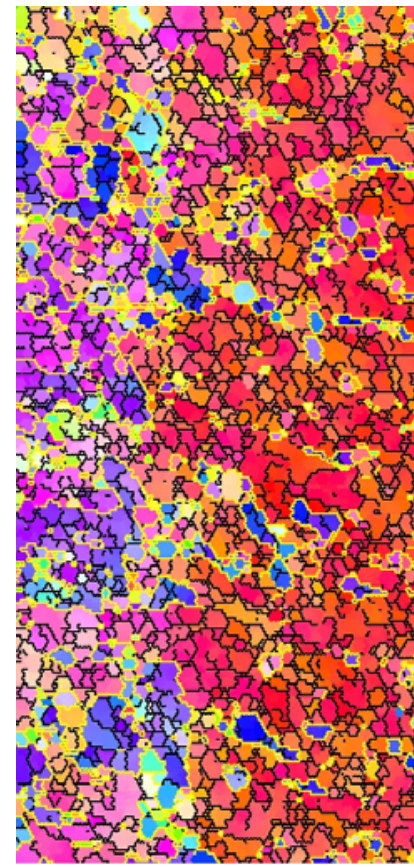

$20.00 \mu \mathrm{m}=20$ steps

$\begin{array}{ccc}\frac{\text { Min }}{0^{\circ}} & \frac{\text { Max }}{15^{\circ}} & \frac{\text { Fraçăo }}{0.618} \\ 15^{\circ} & 60^{\circ} & 0.365\end{array}$
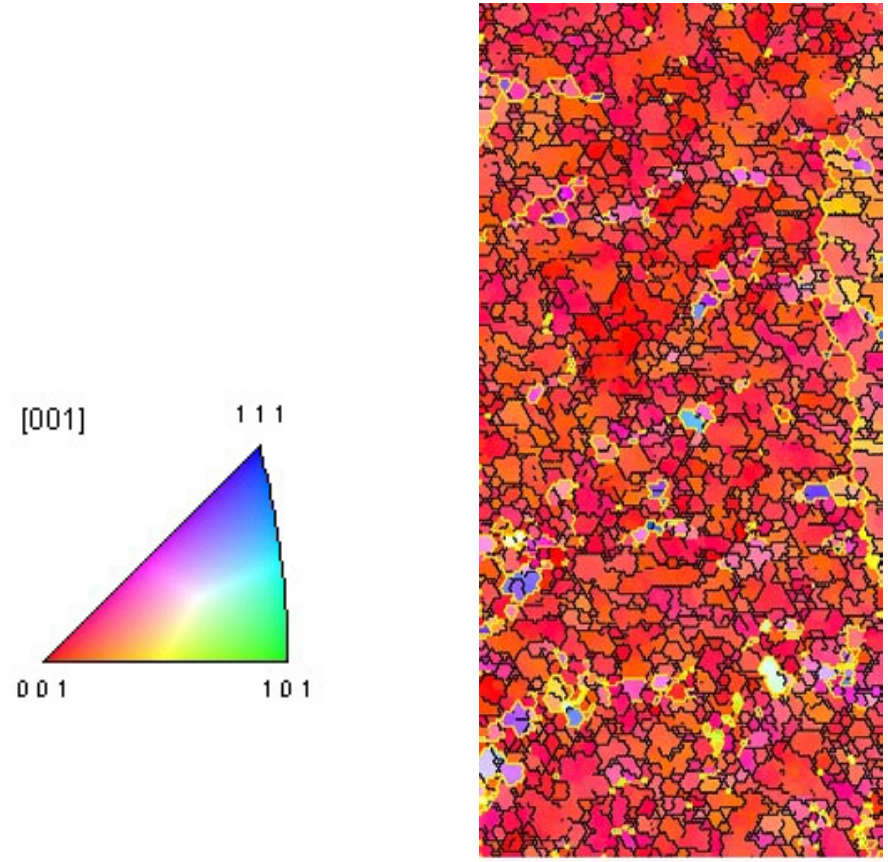

$20.00 \mu \mathrm{m}=20$ steps

$\begin{array}{ccc}\frac{\text { Min }}{0^{\circ}} & \frac{\text { Max }}{15^{\circ}} & \frac{\text { Fração }}{0.831} \\ 15^{\circ} & 60^{\circ} & 0.157\end{array}$

Figura 64 - Mapeamento de orientações da superfície laminada a quente (EBSD), direção de laminação paralela à direção vertical.

Como na amostra caster, foram feitas dez varreduras em diferentes regiões e cada varredura foi feita com o mesmo número de pontos. A Figura 65 apresenta a FDO calculada pela soma destas áreas. A FDO revela que a componente que predomina é a cubo rodado. 


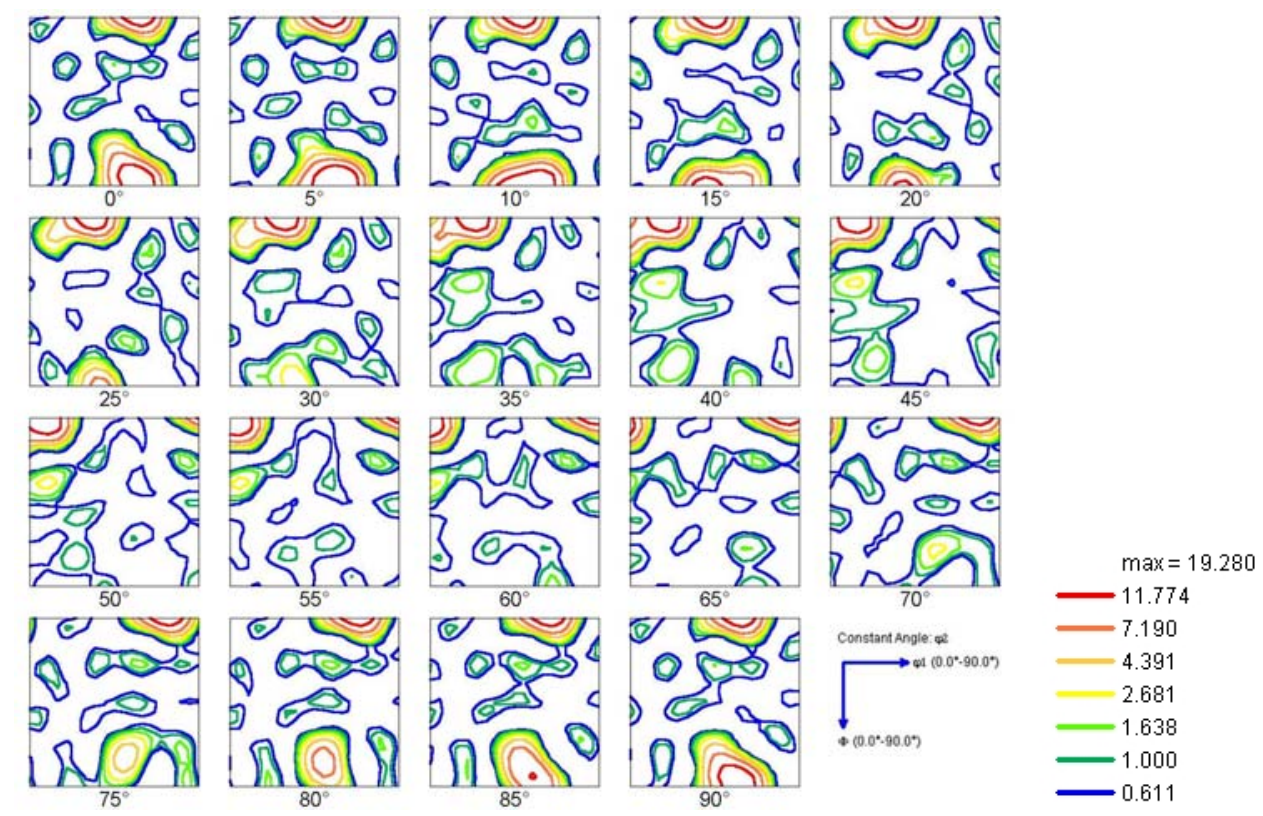

Figura 65 - FDO (EBSD) da amostra laminada a quente superfície.

Comparando-se as medidas de textura tanto da amostra caster quanto da laminada a quente pelo método de elétrons retroespalhados e difração de raios X, nota-se que as mesmas componentes foram encontradas, e a diferença entre os resultados de EBSD e DRX é devida a variações estatísticas que estão envolvidas nos dois métodos. 


\subsection{Microestrutura e textura de laminação a frio de chapas provenientes do processo caster}

Com o intuito de se analisar o comportamento da liga, proveniente do processo caster, durante processamento mecânico, utilizou-se amostras, posteriormente homogeneizada pela Companhia Brasileira de Alumínio - CBA $\left(500^{\circ} \mathrm{C}\right.$ por $\left.12 \mathrm{~h}\right) \mathrm{e}$ laminada a frio também pela CBA. A amostra caster homogeneizada a $500^{\circ} \mathrm{C}$ por $12 \mathrm{~h}$ apresentou uma dureza de $41 \pm 2 \mathrm{HV}(50 \mathrm{gf})$, menor que a amostra caster bruta de fundição como foi mostrado no item anterior, sugerindo a ocorrência de recristalização. A condutividade elétrica encontrada foi de 49\% (também discutida no item anterior). Houve um aumento em relação à bruta de fundição. Este aumento da condutividade foi causado pela diminuição de soluto em solução sólida, ou seja, pela precipitação. A medida de fração volumétrica encontrada foi de $8,6 \pm 0,4 \%$. Porcentagem maior que a encontrada na caster bruta de fundição. $\mathrm{O}$ aumento de fração volumétrica de precipitados está de acordo com aumento da condutividade elétrica.

Amostras que sofreram reduções de $67 \%$ e de $91 \%$ foram analisadas. Através das micrografias (Figura 66) do material homogeneizado e laminado a frio pode-se verificar uma uniformidade nos tamanhos de grão e a deformação preferencial ao longo da direção de laminação.

É importante destacar que a textura não se refere à forma dos grãos, mas sim à forma como a rede cristalina desses grãos é arranjada espacialmente. A presença ou ausência de textura não pode ser inferida a partir da forma dos grãos. Por exemplo, grãos alongados (não equiaxiais) não indicam necessariamente presença de textura cristalográfica. Um processo que introduz textura em um material pode ou não levar à existência de grãos alongados [Viana, 2001]. 


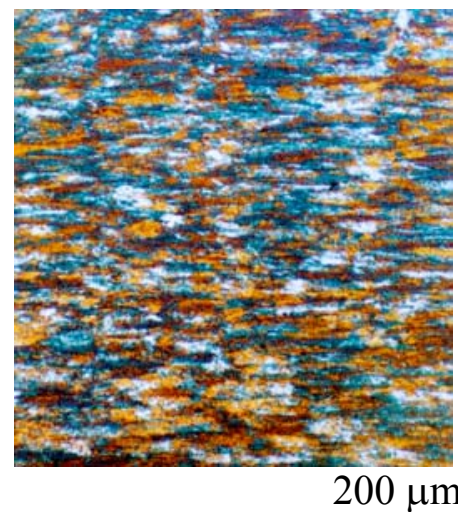

a)

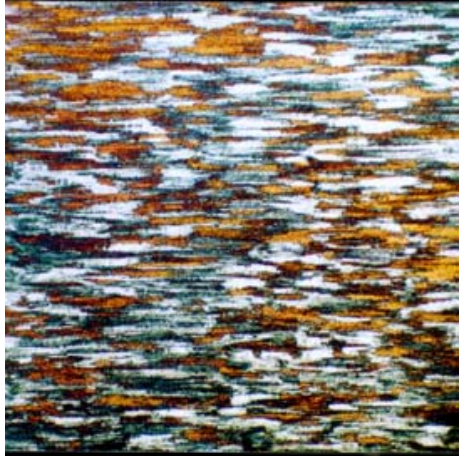

b)

Figura 66 - Micrografias da amostra laminada a frio proveniente do processo caster e homogeneizada $\left(500^{\circ} \mathrm{C} / 12 \mathrm{~h}\right)$ com reduções de $67 \%$ (a) e $91 \%$ (b). Seção da superfície da amostra. Amostra anodizada com solução contendo ácido fluobórico. Microscopia óptica sob luz polarizada. Direção de laminação paralela à direção horizontal.

As FDO's para placas laminadas a frio a $67 \%$ e $91 \%$ (Figuras 67 e 68 ) de redução revelam uma textura de laminação a frio típica do alumínio, composta pelas componentes: latão $\{011\}<211>$, S $\{123\}<634>$ e cobre $\{112\}<111>$ ao longo da fibra $\beta$. Maurice e Driver [1997] encontraram resultado semelhante na região da superfície para liga $\mathrm{AllMn} 1 \mathrm{Mg}$ e reportam que são resultados similares aos obtidos após laminação a frio na mesma liga.

Nota-se que não há diferença entre as texturas de deformação para as duas reduções. Uma sutil diferença encontra-se na intensidade das componentes cobre e S. Para a redução de $67 \% \mathrm{f}(\mathrm{g})=10$ para componente cobre e $\mathrm{f}(\mathrm{g})=6$ para a componente $\mathrm{S}$, enquanto para $91 \%$ de redução as intensidades são um pouco maior, $\mathrm{f}(\mathrm{g})=12$ e $\mathrm{f}(\mathrm{g})=8$, respectivamente. Zhang et al [2002] estudando textura de laminação da liga 3004 observaram que a intensidade da componente cobre aumenta com o aumento da redução e o mesmo ocorre com a componente $\mathrm{S}$ e latão, porém o aumento destas é menor. No entanto, no presente trabalho a intensidade da componente latão mostra-se praticamente constante. 
A componente cubo rodado $\{001\}<110>$ encontrada na superfície da amostra caster não foi encontrada após laminação a frio. Durante laminação, a textura cubo rodado se transforma em textura tipo latão, cobre e S [Zhang et al, 2002]. Conhecendose a textura inicial e a textura de deformação torna-se possível entender a evolução da textura. Estudos com monocristais na orientação $\{001\}<110>$ foram realizados e verificou-se que esta orientação é bastante instável durante a laminação, sofrendo grandes rotações ao redor de DT (direção transversal) [Li e Liu, 2002]. Esta rotação ao redor de DT da orientação $\{001\}<110>$ vai em direção a $(112)<111>$ e $(112)<111>$. 


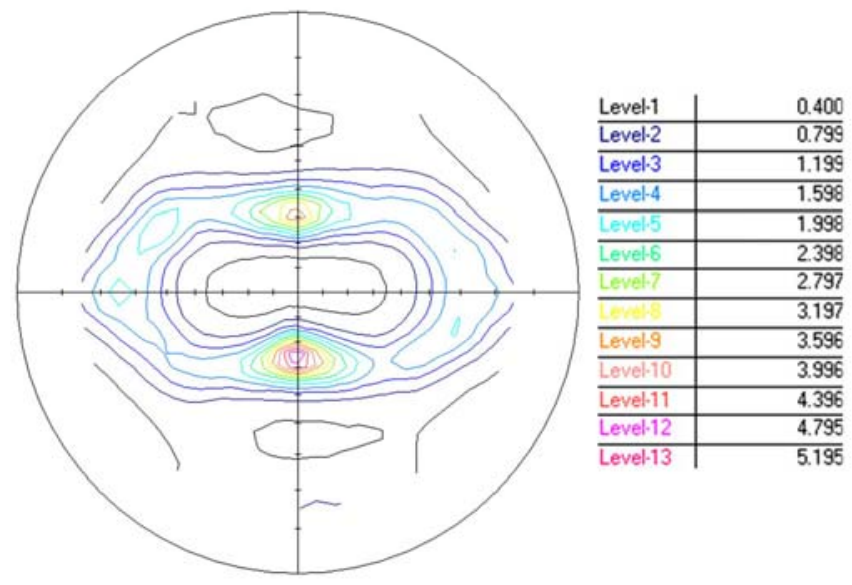

a)
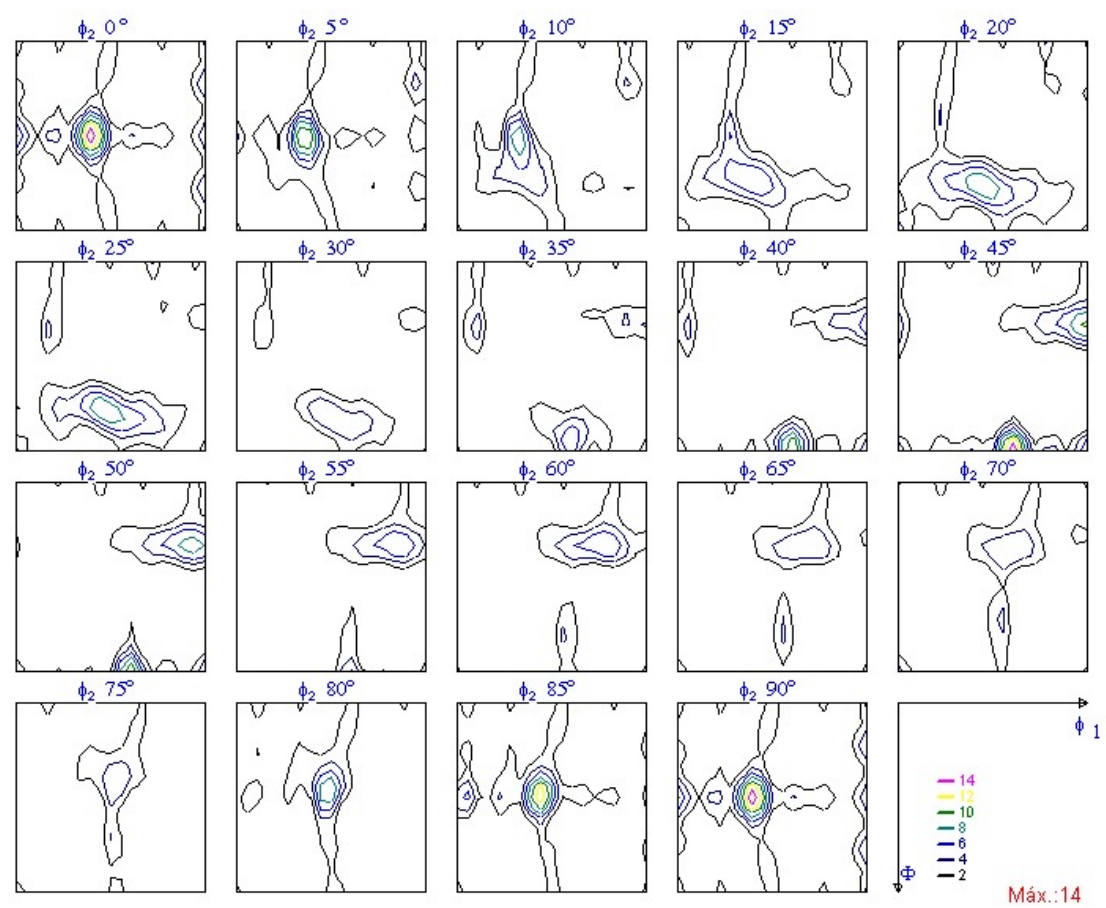

b)

Figura 67 - a) FP 111 obtida por difração de raios X da amostra caster laminada a frio com 67\% de redução; b) FDO (difração de raios X) da amostra caster laminada a frio com $67 \%$ de redução. 

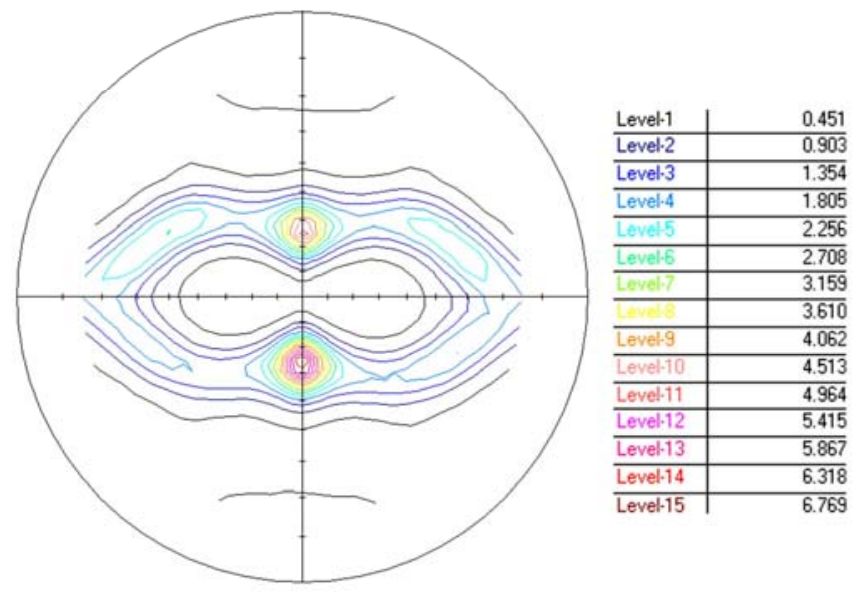

a)
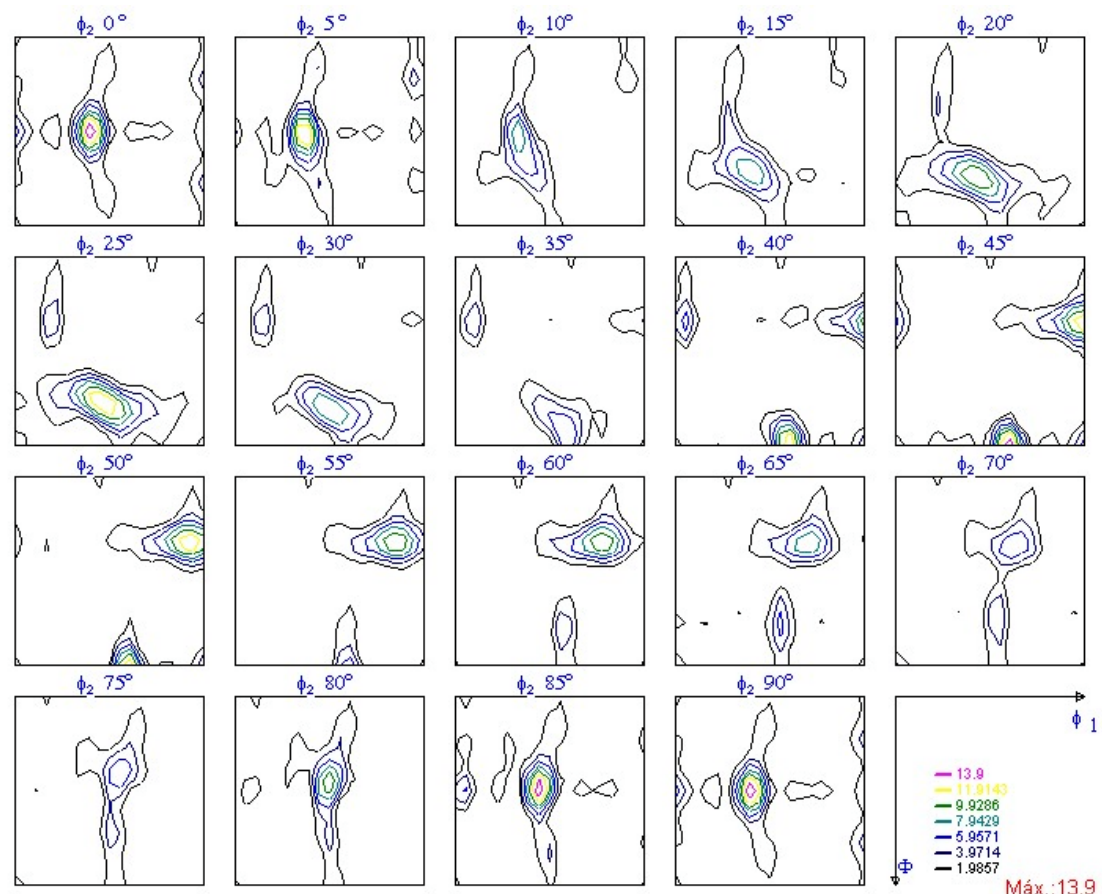

b)

Figura 68 - a) FP 111 obtida por difração de raios X da amostra caster laminada a frio com 91\% de redução; b) FDO (difração de raios X) da amostra caster laminada a frio com $91 \%$ de redução. 


\subsection{Microestrutura, textura e microtextura de recristalização de chapas provenientes do processo caster}

Nas Figuras 69 e 70 encontram-se amostras que sofreram tratamento térmico de homogeneização e foram laminadas a frio até redução de 67\% e 91\%. Após laminação a frio as amostras foram recristalizadas a $400^{\circ} \mathrm{C}$ por $1 \mathrm{~h}$. A análise de textura de laminação já foi apresentada no item anterior.

Nota-se que alguns grãos recristalizados cresceram mais que outros. Esta heterogeneidade de tamanho de grão está relacionada com a heterogeneidade de distribuição de partículas. Os elementos em solução sólida quando precipitam durante recristalização (vide Figura 8) são barreiras para a movimentação de contornos de grão. Portanto, em regiões com maior quantidade de elementos em solução sólida os grãos são menores, enquanto em regiões com menor quantidade de elementos em solução sólida os grãos são maiores. Esta heterogeneidade de partículas tem sua origem já na solidificação do metal. Durante solidificação, as dendritas, que são as primeiras regiões que solidificam, se tornam áreas com pouca quantidade de elementos em solução sólida, praticamente alumínio puro. Conforme as dendritas vão se solidificando os elementos que se encontravam dissolvidos nestas regiões passam a se concentrar na região vizinha, nas regiões interdendríticas. Com isso, nas regiões interdendríticas há maior quantidade de elementos em solução sólida.

Recozimento em temperaturas mais altas causa freqüentemente recristalização. A ocorrência de recristalização pode gerar uma orientação cristalográfica preferencial completamente diferente daquela gerada pela deformação. $\mathrm{Na}$ realidade, a recristalização pode tanto levar à ausência de textura, como desenvolver componentes de textura extremamente intensas ou, simplesmente, não alterar a textura de deformação [Lima et al, 2001]. Por exemplo, no alumínio de alta pureza, submetido a altas porcentagens de redução por laminação, pode ocorrer, após o recozimento, uma textura extremamente intensa, do tipo $\{100\}<001>$ (conhecida como textura do tipo cubo). Esta alteração da textura de deformação, durante a recristalização, é consistente com a idéia de que o fenômeno da recristalização é o resultado de um conjunto de alterações na microestrutura de um material, 
em decorrência de tratamento térmico, com novos grãos nucleando e crescendo. Estes novos grãos podem ter uma orientação diferente daquela orientação dos grãos da microestrutura deformada, pois os grãos formados estão muito mais livres de defeitos, ou seja, com menor energia acumulada. A presença de precipitados, especialmente de precipitados grandes (incoerentes e não cisalháveis, que é o caso da liga 3003) que estimulam a nucleação da recristalização, favorecem a presença de textura ao acaso, ou melhor, de ausência de textura, pois os precipitados grandes favorecem a nucleação ao seu redor e esta nucleação pode não ter relação com a matriz. Em geral, a textura de recristalização do tipo cubo é fortalecida por altas reduções a frio e por altas temperaturas de recristalização. A textura do tipo cubo é em geral indesejável, pois causa a formação de orelhas ("earing") durante a estampagem.

Após recristalização a $400^{\circ} \mathrm{C}$ na amostra com $91 \%$ de redução, a textura apresenta componentes retidas da textura de laminação, a componente cubo e a componente $\{001\}<310>$ como mostra a Figura 71 . As componentes da fibra $\beta$ retidas têm nível de intensidade comparável ao estado laminado, apenas a componente latão apresentou intensidade um pouco menor no estado recristalizado. Benum and Nes [1997] realizaram um trabalho cujo objetivo era explorar o efeito da precipitação no desenvolvimento de grãos de orientação cubo durante a recristalização. Eles verificaram que para recristalização a $275^{\circ} \mathrm{C}$ houve predominância da textura cubo enquanto na recristalização a $400^{\circ} \mathrm{C}$ apareceram as componentes retidas da textura de laminação e a componente cubo. Concluíram que a mudança de textura com o aumento da temperatura, de um tipo de núcleo (cubo) para uma família de núcleos (fibra $\beta$ ) é induzida pelo efeito da precipitação.

Doherty [1997] reporta que há uma significativa textura de laminação retida em alumínio comercialmente puro laminado a frio e recristalizado. E explica a presença da textura de laminação retida após recristalização. A liga de alumínio contendo grandes constituintes ricos em ferro de 1 a $2 \mu \mathrm{m}$ apresentará diferença de orientação na zona deformada de tamanho igual a duas vezes este tamanho, então esta zona de deformação será mais grossa do que a banda deformada. Esta zona de deformação aumentará a diferença de orientação da banda de deformação permitindo que novos grãos da orientação retida de laminação cresça através das bandas de deformação. Portanto, o modelo orientation pinning, que é caracterizado pelo impedimento do crescimento de um núcleo pela baixa 
mobilidade de contornos de baixo ângulo, é fraco para alumínio comercialmente puro laminado a frio, explicando a forte textura de laminação retida na recristalização.

Na Figura 72 é apresentada a FDO da amostra caster com 67\% de redução e recristalizada a $400^{\circ} \mathrm{C}$ por 1 hora. Nota-se que neste caso não houve componente de textura retida da laminação. A textura neste caso apresenta a componente $\{001\}<310>$ e a componente cubo, sendo a primeira de maior intensidade. Esta componente é conhecida como cubo $_{N D}$, ou seja, rotação da orientação cubo em torno da direção normal $\{001\}<u v 0>$, visível ao longo de $\varphi_{1}, \operatorname{com} \varphi_{2}=\phi=0$. Os gráficos de fibras ao longo de $\varphi_{1}, \operatorname{com} \varphi_{2}=\phi=$ 0, apresentados na Figura 73 mostram a diferença entre as duas amostras. 

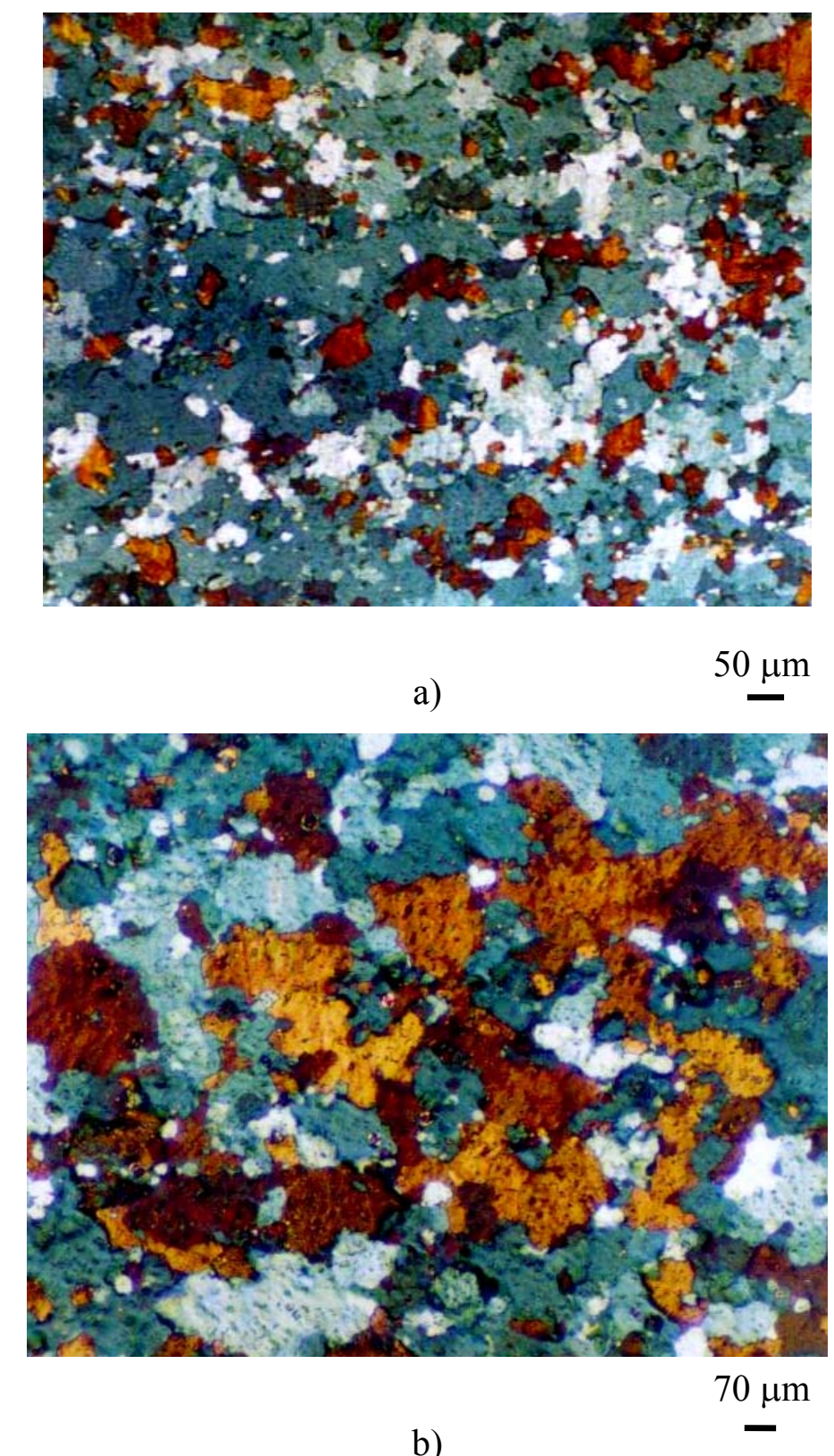

Figura 69 - Microestrutura da amostra caster recristalizada (após 67\% de redução e recozimento a $400^{\circ}$ por 1 hora), microscopia ótica sob luz polarizada. Seção da superfície da amostra. Amostra anodizada com solução contendo ácido fluobórico. Microscopia óptica sob luz polarizada. Direção de laminação paralela à direção horizontal. 


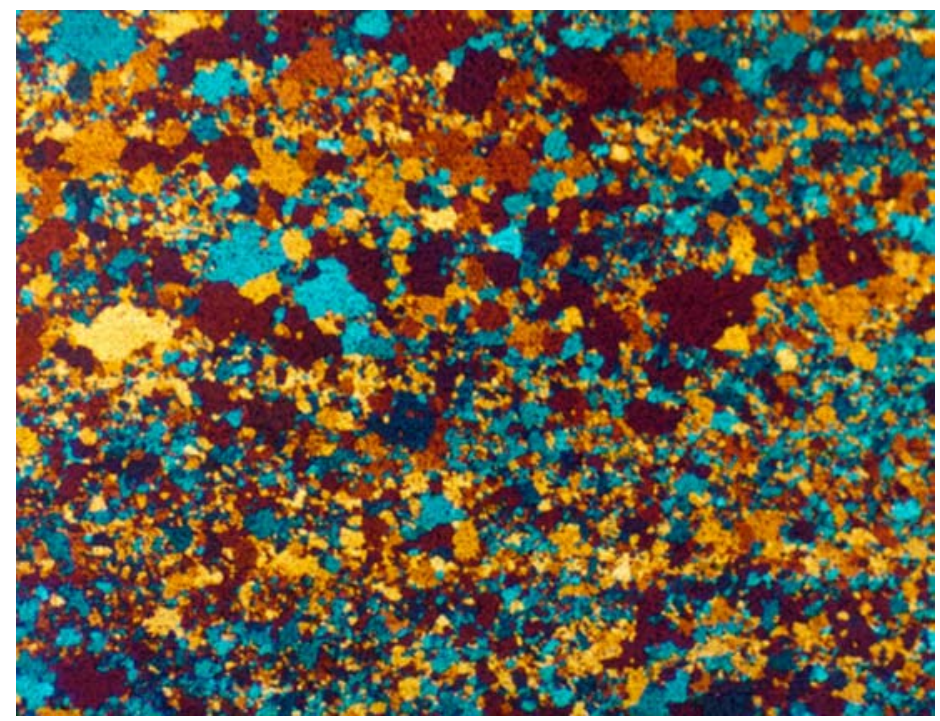

a)
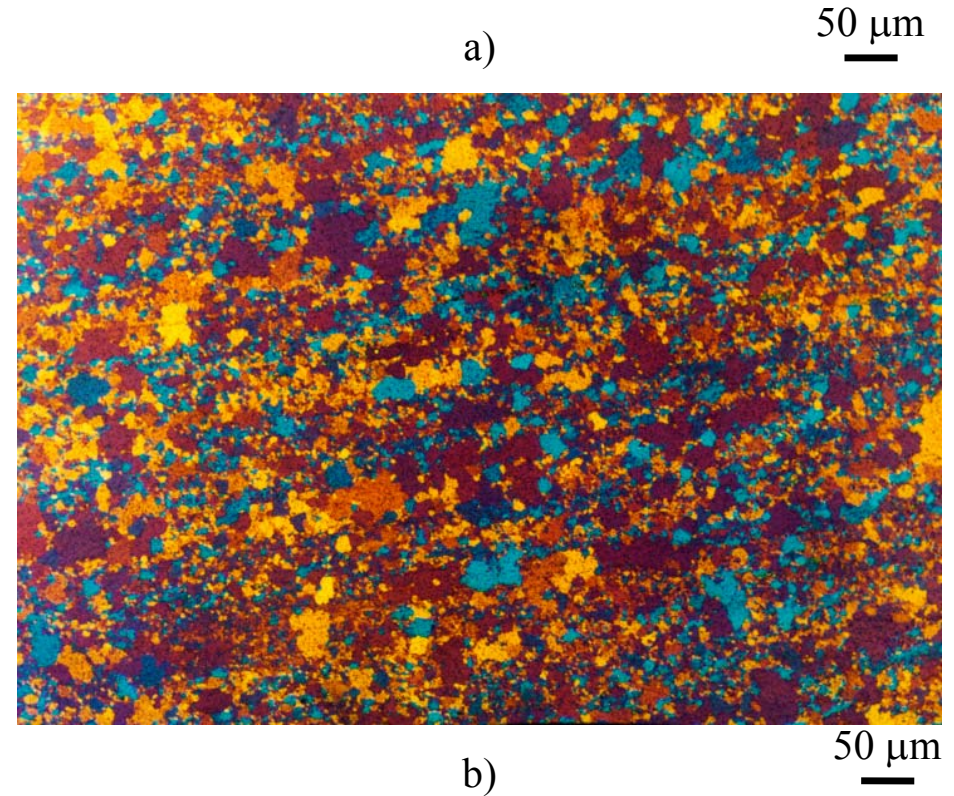

Figura 70 - Microestrutura da amostra caster recristalizada (após 91\% de redução e recozimento a $400^{\circ}$ por 1 hora), microscopia ótica sob luz polarizada. Seção da superfície da amostra. Amostra anodizada com solução contendo ácido fluobórico. Microscopia óptica sob luz polarizada. Direção de laminação paralela à direção horizontal. 
Na Figura 74 é apresentado o mapeamento de orientações da amostra caster com 91\% de redução e recristalizada. Nesta região observa-se completa recristalização. A FDO gerada revela as mesmas componentes encontradas através de difração de raios $\mathrm{X}$, uma pequena diferença encontrada apenas na intensidade. A FDO gerada por EBSD (Figura 75) para a amostra com $67 \%$ de redução e recristalizada também revela as mesmas componentes encontradas através de difração de raios $\mathrm{X}$, uma pequena diferença encontrada também apenas na intensidade.

Com auxílio da análise das microestruturas apresentadas nas Figuras 69 e 70 e dos mapeamentos de orientações nas Figuras 74 e 75, nota-se que a forma dos grãos é irregular, mais próximo a contornos serrilhados.

Pode-se notar a presença de pequenos grãos no interior de grãos grandes na Figura 75. Não houve predominância de orientação para estes pequenos grãos (island grains) ou para os grãos grandes, onde este fenômeno foi evidenciado. Esta estrutura pode ter ocorrido pelo fato de alguns grãos crescerem mais rápido do que outros, e os mais lentos são subseqüentemente rodeados [Daaland, 1996]. 


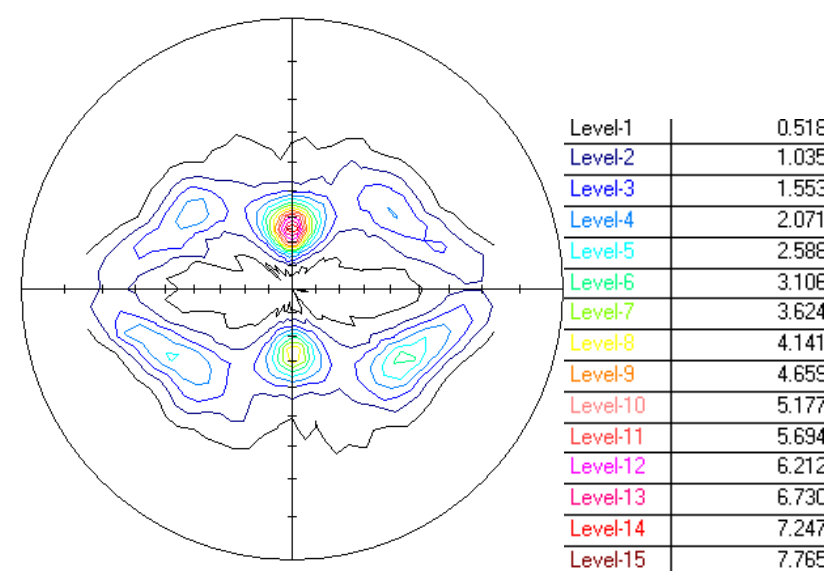

a)
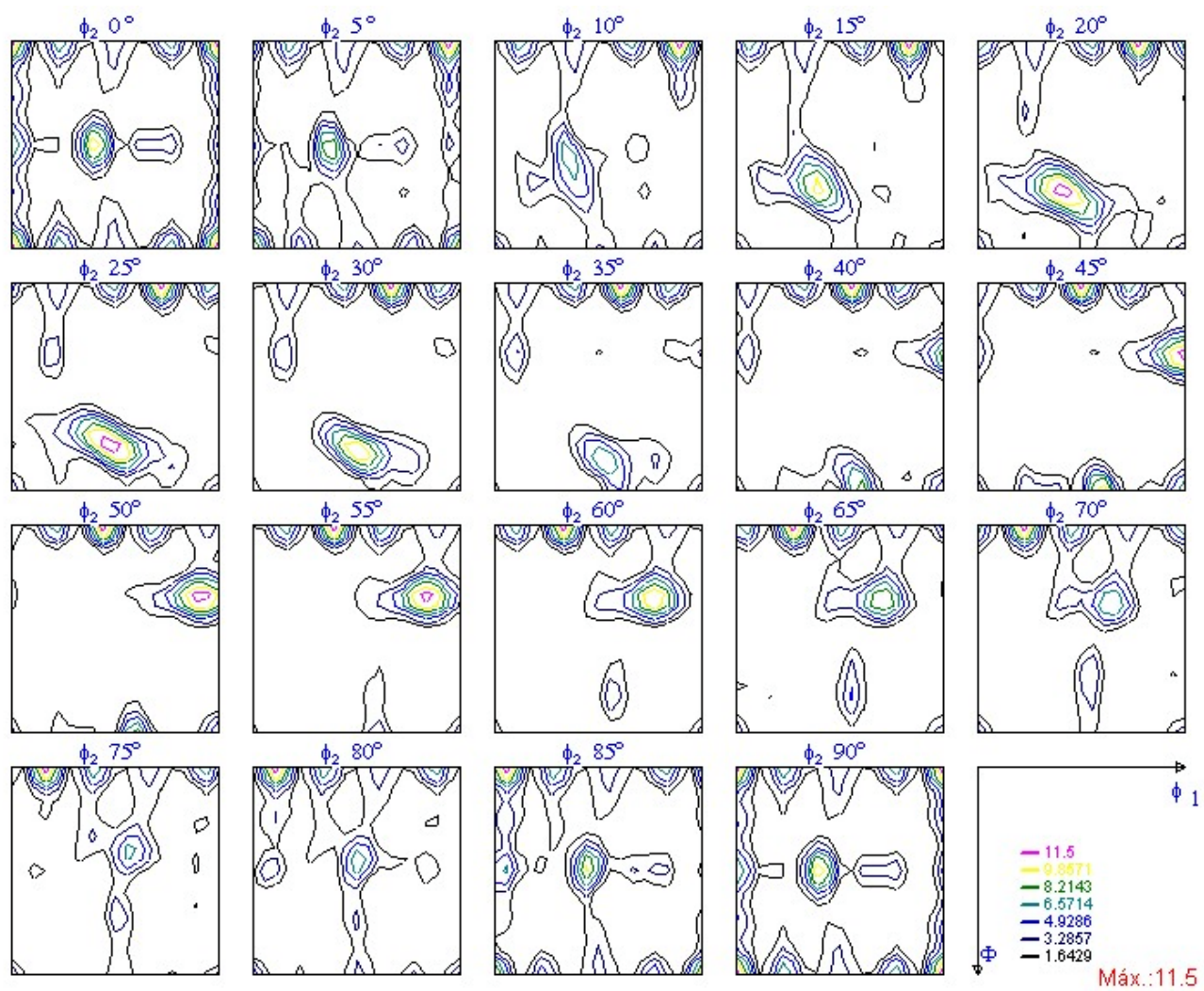

b)

Figura 71 - a) FP 111 obtida por difração de raios $X$ da amostra caster recristalizada a $400^{\circ} \mathrm{C} / 1 \mathrm{~h}$ após $91 \%$ de redução; b) FDO (difração de raios X) da amostra caster recristalizada a $400^{\circ} \mathrm{C} / 1 \mathrm{~h}$ após $91 \%$ de redução. 


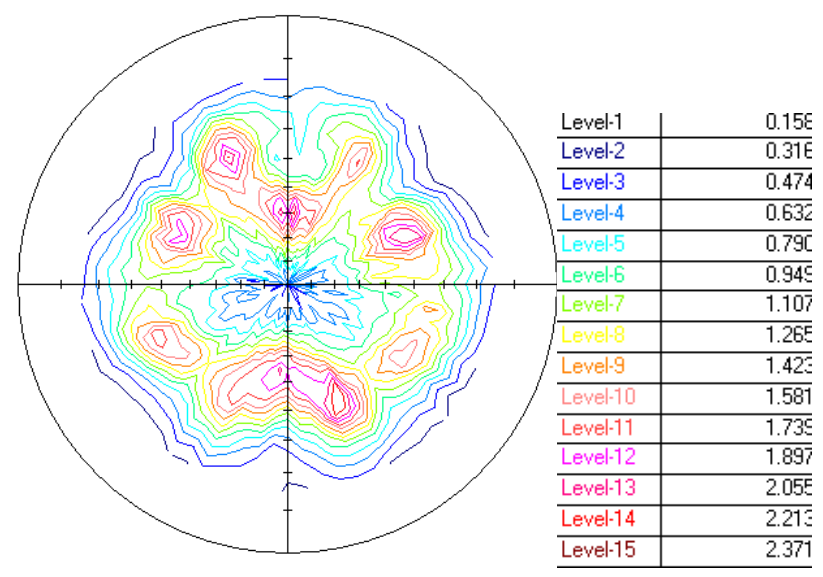

a)
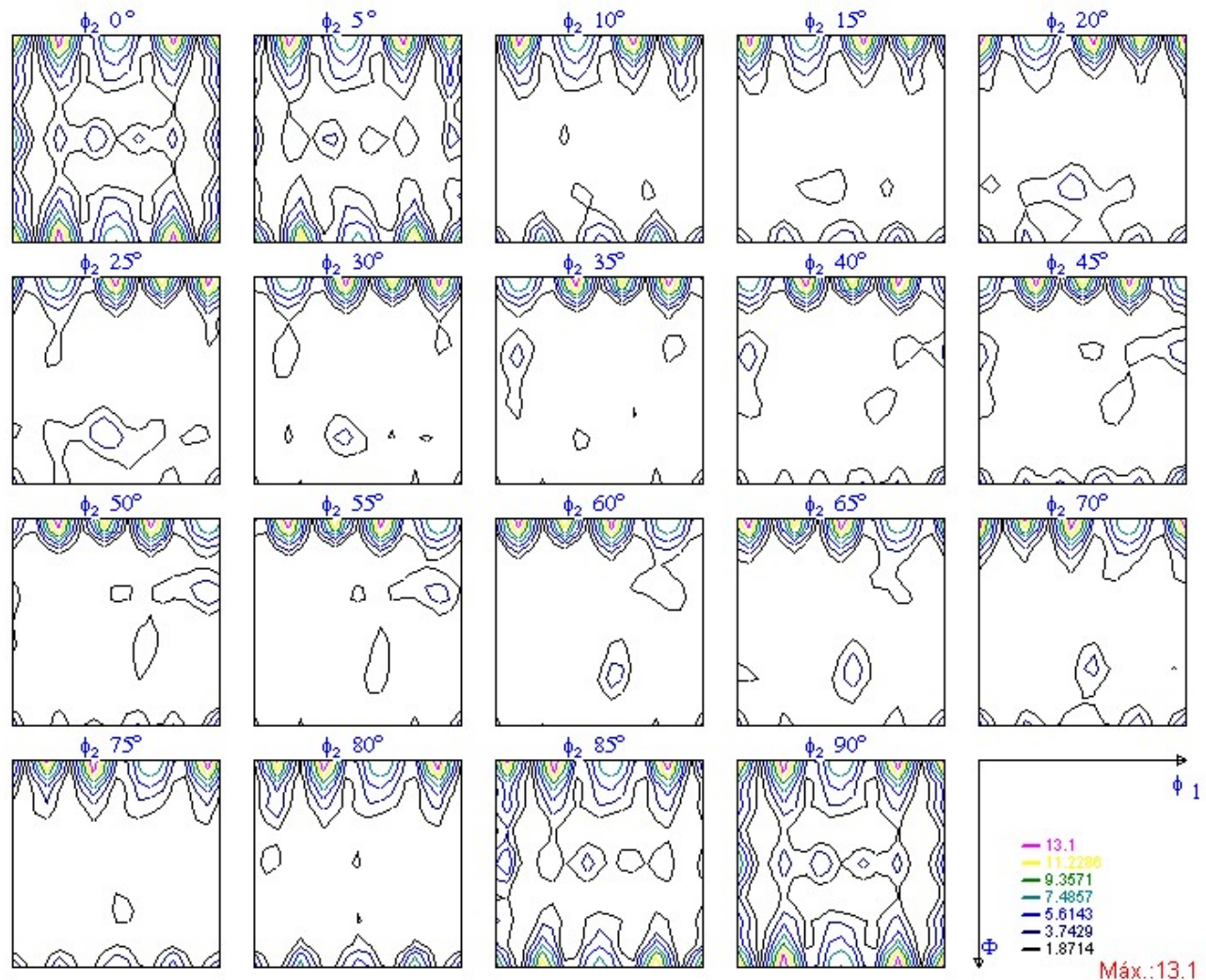

b)

Figura 72 - a) FP 111 obtida por difração de raios $\mathrm{X}$ da amostra caster recristalizada a $400^{\circ} \mathrm{C} / 1 \mathrm{~h}$ após $67 \%$ de redução; b) FDO (difração de raios X) da amostra caster recristalizada a $400^{\circ} \mathrm{C} / 1 \mathrm{~h}$ após $67 \%$ de redução. 


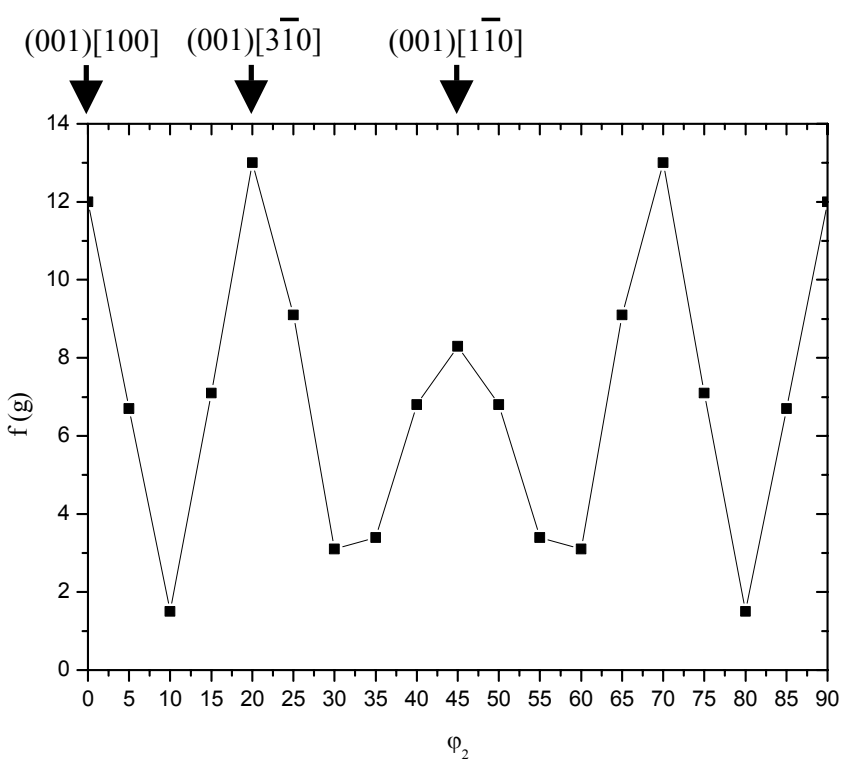

a)

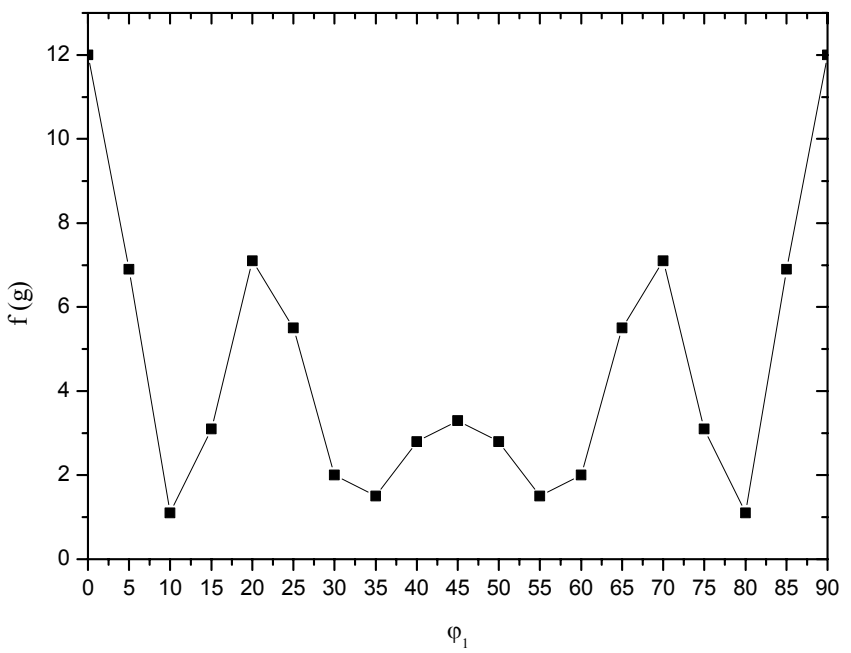

b)

Figura 73 - Gráfico de fibra com $\varphi_{2}=0$ e $\phi=0$ : a) $67 \%$ de redução e recristalizada e b) $91 \%$ de redução e recristalizada. 


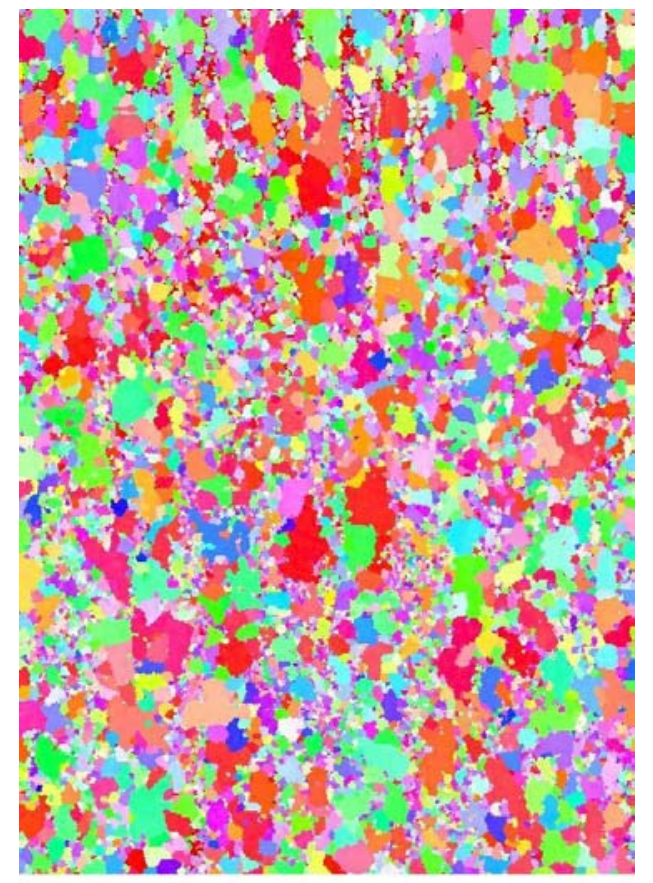

$240.0 \mu \mathrm{m}=80$ steps IPF [001]

a)

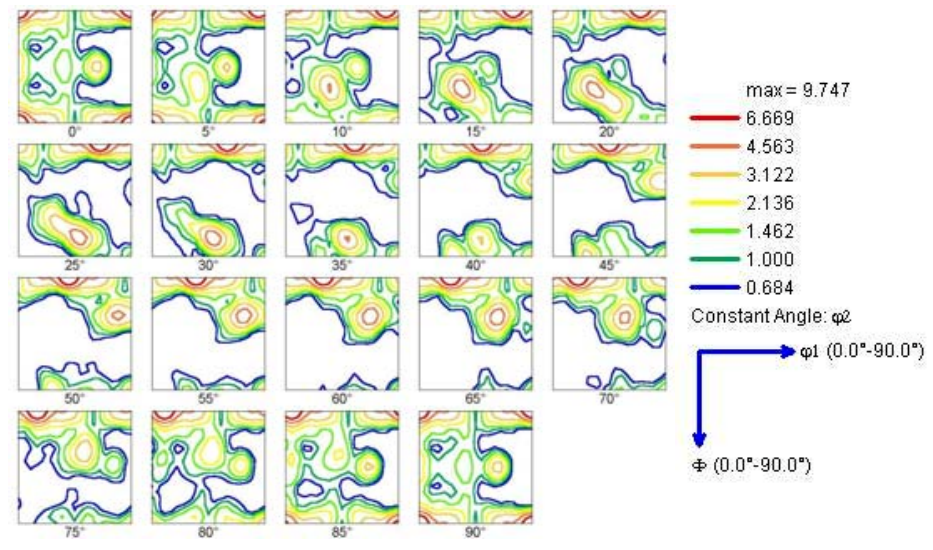

b)

Figura 74 - Análise através de EBSD da amostra caster com 91\% de redução e recristalizada a $400^{\circ} \mathrm{C}$ por 1 hora: a) Mapeamento de orientações; b) FDO da região analisada. Direção de laminação paralela à direção vertical. 


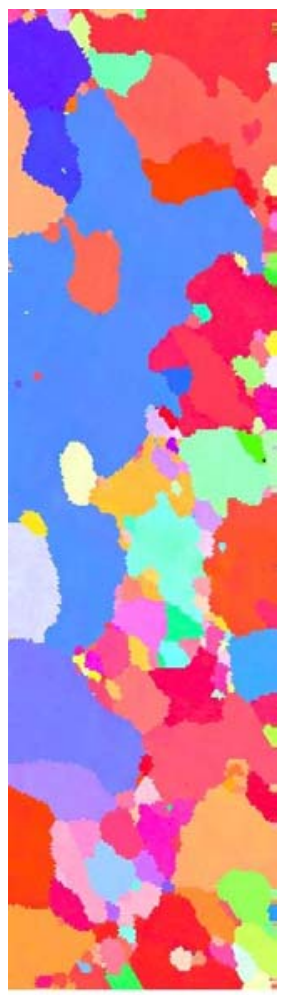

$20.00 \mu \mathrm{m}=20 \mathrm{st}$

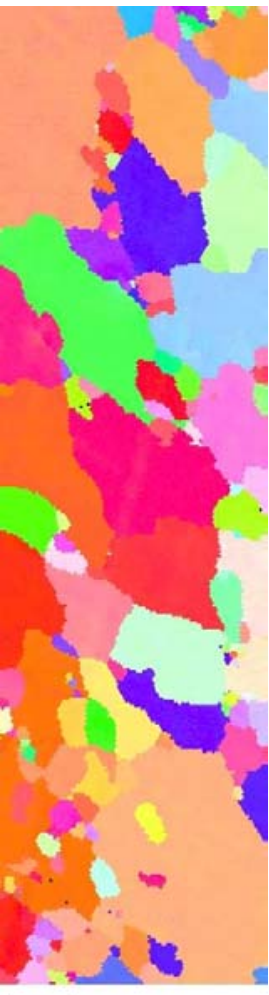

$20.00 \mu \mathrm{m}=20$ st

a)

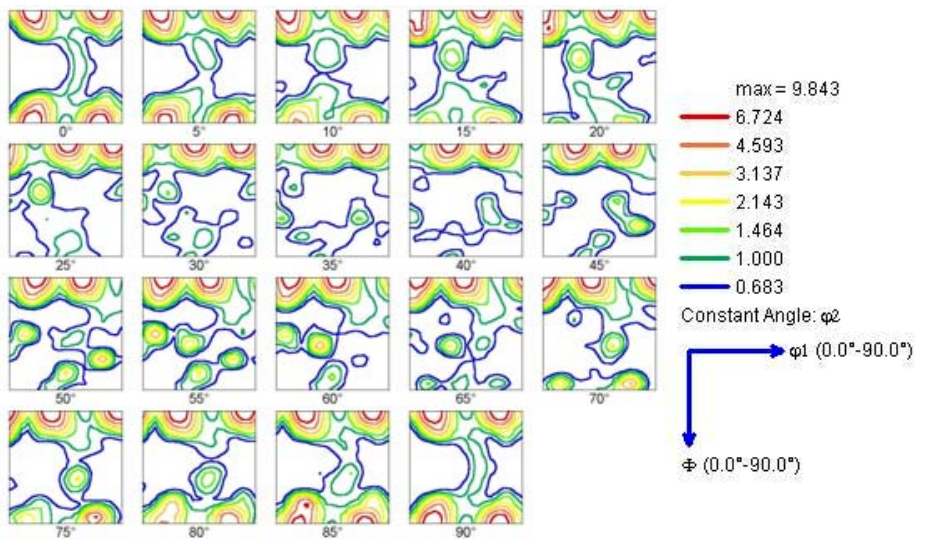

b)

Figura 75 - Análise através de EBSD da amostra caster com $67 \%$ de redução e recristalizada a $400^{\circ} \mathrm{C}$ por 1 hora: a) Mapeamento de orientações; b) FDO da região analisada. Direção de laminação paralela à direção vertical. 


\subsection{Estudo do efeito do tratamento térmico prévio de homogeneização no encruamento e na posterior recristalização de chapas provenientes do processo caster}

Com o intuito de se comparar o efeito da homogeneização antes da laminação a frio, duas placas obtidas através do processo roll caster foram laminadas no laminador duo reversível instalado no Departamento de Engenharia Metalúrgica e de Materiais da EPUSP.

As duas placas possuíam, antes da laminação, as mesmas dimensões: 200 mm x 35 $\mathrm{mm}$ e 7,4 mm de espessura. Uma placa era bruta de fundição e a outra sofreu tratamento térmico prévio de homogeneização $\left(550^{\circ} / 24 \mathrm{~h}\right.$; tratamento feito em uma mufla da marca Lindberg, a amostra foi resfriada em água com gelo). Durante a laminação a frio foram retiradas amostras das duas placas nas mesmas reduções, como foi mostrado na Tabela 7 do capítulo 3.

Após laminação a frio, amostras com 91\% de redução das duas placas sofreram tratamentos térmicos entre $100^{\circ} \mathrm{C}$ e $550^{\circ} \mathrm{C}$ por 1 hora, para estudo da recristalização (forno tubular da marca Lindberg instalado no Departamento de Engenharia de Materiais Faenquil - Lorena/SP). Medidas de microdureza Vickers em função da redução em área

durante laminação a frio e em função da temperatura nas duas condições (aqui denominadas de caster bruta de fundição e caster com prévia homogeneização) foram determinadas em um microdurômetro Micromet da Buehler, instalado no Departamento de Engenharia de Materiais da Faenquil - Lorena, com carga de 50 gf. Foram feitas imagens por transmissão para caracterizar o início da recristalização nas duas condições, além da microscopia ótica.

Uma boa distribuição da fase eutética e de intermetálicos é essencial para um bom andamento do processo de laminação, desse modo, processos de homogeneização são realizados antes da laminação e tem substancial efeito na microestrutura gerada na chapa caster.

Durante a laminação a frio, as duas chapas tiveram comportamento similar, como mostra a Figura 76. A amostra aqui designada como caster se refere à chapa que foi laminada a frio sem ser homogeneizada, ou seja, no estado bruto de fundição. Enquanto a amostra caster homogeneizada se refere à chapa que sofreu tratamento térmico de $550^{\circ} \mathrm{C} /$ 24h. Durante este tratamento de homogeneização houve acentuado crescimento de grão, 
como pode ser visto na Figura 77. Esta imagem foi feita a partir de análise de dados de varredura feita por EBSD. É interessante observar que no estado inicial, sem deformação, a amostra caster é substancialmente mais dura que a amostra caster homogeneizada (54 HV para caster e 39,4 HV para a caster homogeneizada). Esta diferença de dureza está relacionada à diferença de encruamento e de quantidade de soluto em solução sólida. Já foi discutido na seção 4.1 que há um aumento da condutividade elétrica da amostra caster com tratamento térmico de homogeneização em relação à amostra bruta de fundição. E este aumento é causado pela diminuição de soluto em solução sólida, ou seja, pela precipitação.

A análise por microscopia eletrônica de transmissão da amostra caster (apresentada item 4.1) mostrou a presença de apreciável densidade de discordâncias, com subestrutura típica de deformação a quente. Portanto, a amostra caster está, na realidade, levemente encruada. Este encruamento poderia ter causado o aparecimento de grãos grosseiros (recristalização secundária induzida por deformação). A presença de grãos exageradamente grandes em metais e ligas que foram levemente deformados e posteriormente recozidos é freqüente. Isto tanto pode ocorrer em um aço ferrítico baixo carbono que sofreu uma leve redução no passe de acabamento (“skin pass") em laminação a frio, como em um metal ou liga que apresenta gradientes de deformação, por exemplo, abaixo de uma simples impressão de dureza [Schumann, 1980]. Neste último caso, a região de grãos exageradamente grandes não aparece imediatamente abaixo da marca de dureza, mas sim a uma certa distância abaixo da mesma, sugerindo a existência de uma deformação crítica para a ocorrência do fenômeno. No início do século XX, este fenômeno foi muito utilizado para a obtenção de monocristais ("strain-anneal method"). Para isto, metais puros levemente deformados eram aquecidos sob gradiente de temperatura. Em 1999, Cahn publicou uma revisão histórica sobre o uso de monocristais metálicos em pesquisa [Cahn, 1999], na qual descreve estes experimentos do começo do século XX e os interpreta como recristalização e não como crescimento anormal de grãos (recristalização secundária). É importante acentuar que gradientes de deformação e a existência de regiões levemente deformadas são freqüentes na manufatura de objetos metálicos, embora, na maioria dos casos, o material não seja posteriormente recozido.

No decorrer da década de 1970, Antonione, Riontino e co-autores [Antonione et al, 1973, 1977; Riontino et al, 1979] investigaram o efeito de pequenos graus de deformação a 
frio no tamanho de grão após o posterior recozimento de ferro puro. Amostras de ferro com pureza superior a 99,998 \% e diâmetro médio de grão de $50 \mu \mathrm{m}$ foram deformadas de 2,5 e $10 \%$ em tração na temperatura ambiente, e em seguida recozidas a 664,680 e $690^{\circ} \mathrm{C}$. Enquanto nas amostras não deformadas o crescimento de grão era contínuo ou normal, nas amostras pré-deformadas, após um certo período de incubação, apenas alguns poucos grãos cresciam abruptamente; crescimento anormal ("abnormal growth") segundo os autores. O tempo de incubação e o diâmetro final máximo diminuíram com o aumento do grau de deformação. Efeito similar foi observado por Randle e Brown [1988] em um aço inoxidável austenítico do tipo Fe-20\%Cr-25\%Ni-Nb deformado de 2 e $7 \%$ em tração, que foi denominado pelos autores crescimento anômalo de grão induzido por deformação ("strain-enhanced anomalous grain growth"). Mais tarde, Randle [1993] estudou o efeito da velocidade de aquecimento no crescimento anômalo de grão causado por $2 \%$ de deformação por compressão em níquel puro e concluiu que o aquecimento lento era mais eficiente para induzir o aparecimento dos grãos grandes do que o aquecimento rápido. Randle [1988, 1993a, 1993b] descreve o fenômeno como crescimento anormal de grão ou recristalização secundária e o atribui ao aumento da mobilidade dos contornos induzida por deformação. Mais recentemente, crescimento anormal de grãos induzido por baixos graus de deformação a frio foi detectado em cobre de alta pureza [Koo et al, 2002] deformado na faixa de 2 a 8\% em compressão, em superliga à base níquel [Cho et al, 2001] deformada na faixa de 1 a 4\% em compressão e em aço ferrítico de baixo teor de carbono contendo cerca de $1 \%$ de silício [Cheong et al, 2003] deformado até $10 \%$ de redução por laminação (“temper rolling"). Em geral, estes trabalhos [Randle 1988, 1993a, 1993b; Koo et al, 2002; Cho et al, 2001; Cheong et al, 2003] consideram que pequenas deformações possibilitam a introdução de discordâncias ("extrinsic dislocations") nos contornos de grãos, alterando a "estrutura" e a mobilidade dos mesmos. Segundo Koo e co-autores [2002], o nível de deformação crítica depende do tamanho de grão inicial e da temperatura de tratamento, mas situa-se entre 2 e $4 \%$ para a maioria dos metais. Na deformação crítica, apenas alguns contornos, os contornos facetados, são seletivamente distorcidos pelas "extrinsic dislocations", aumentando suas mobilidades e induzindo o crescimento rápido de alguns poucos grãos. Para deformações maiores, mas ainda menores que a deformação crítica para ocorrência de recristalização, um número maior de contornos é ativado e o tamanho de grão 
resultante é menor. As evidências experimentais em favor da ocorrência de crescimento anormal ou recristalização secundária durante o recozimento após baixos graus de deformação são numerosas, mas não são consensuais. Por exemplo, trabalho muito recente [Murakami et al, 2004] apresentado no principal congresso internacional da área de recristalização e crescimento de grão interpreta o efeito de pequenas deformações em aço elétrico de grão não orientado contendo $0,5 \%$ de silício em termos do mecanismo de recristalização por migração de contorno de grão induzida por deformação ("strain induced boundary migration"; SIBM). O livro texto mais recente e importante da área de recristalização e crescimento de grão também prefere interpretar este fenômeno em termos de recristalização [Humphreys, 1996]. Trabalho recente de tese de Guimarães de Lima [Lima, 2005] em aços ferríticos apresenta evidências de que o aparecimento de grãos grandes após recozimento de amostras levemente deformadas é causado por recristalização primária e não por recristalização secundária. Ou seja, para ter certeza, de que o crescimento exagerado de grão ocorrido na amostra caster homogeneizada a $550^{\circ} \mathrm{C}$ por $24 \mathrm{~h}$ foi causado por recristalização secundária induzida por deformação e não por recristalização primária, são necessários estudos sistemáticos complementares.

Resultados de identificação de CSL (Coincidence Site Lattice) dos contornos, da amostra caster, ao longo da espessura, são apresentados na Figura 78. O reticulado de coincidência (Coincidence site lattice, CSL) é uma relação geométrica, a qual é fundamental para entender a organização dos átomos do reticulado nos contornos de grão. Considerando-se duas redes cristalinas interpenetradas, se transladarmos uma para fazer com que um ponto da rede coincida com a outra, e, com isto, outros pontos da rede coincidirem, então estes pontos formam um reticulado de coincidência. A relação recíproca de sítios CSL e de sítios da rede é denotada por $\Sigma$. Contornos com $\Sigma 1$ são contornos de baixo ângulo e de baixa energia, constituídos de discordâncias, ou seja, são subcontornos e não contornos de alto ângulo. Medidas de identificação de contornos que possuem CSL na amostra caster foram feitas com o objetivo de identificar a existência de contornos de alta coincidência, antes do tratamento térmico de homogeneização de $550^{\circ} \mathrm{C}$ por $24 \mathrm{~h}$. Pelas Figuras 78 a/ b/ c nota-se a presença de uma fração relativamente alta de $\Sigma 1$ ao longo da espessura da amostra caster bruta de fundição. 


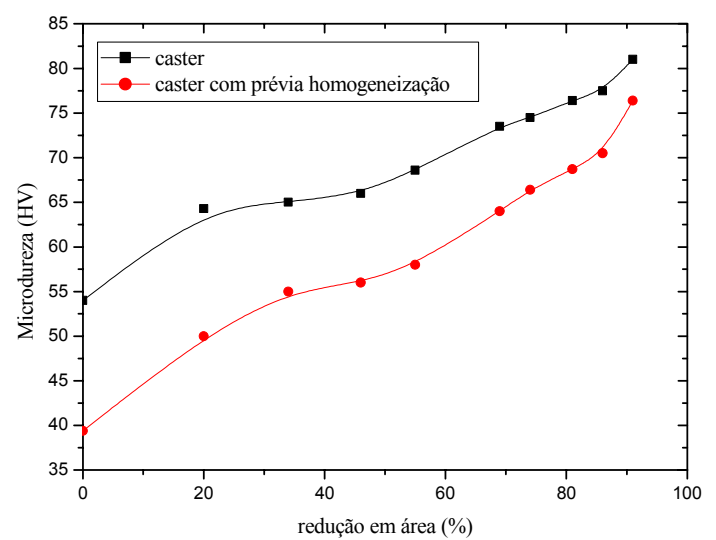

Figura 76 - Variação da microdureza Vickers (carga 50gf) em função da redução em área durante laminação a frio de duas condições: caster e caster com prévia homogeneização. A designação caster se refere à amostra no estado bruto de fundição.

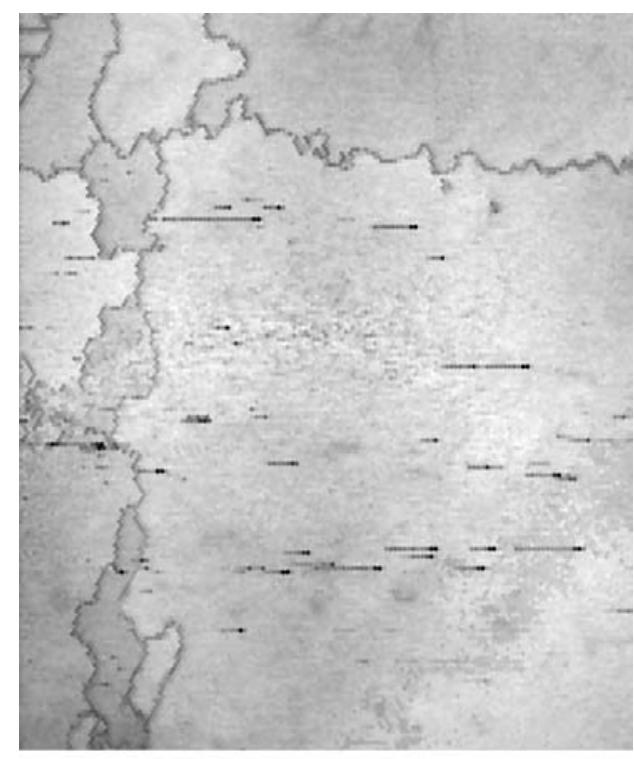

$1200.0 \mu \mathrm{m}=30$ steps $I Q 14.03 \ldots 95.958$

Figura 77 - Image Quality de uma amostra retirada da chapa que sofreu tratamento térmico de $550^{\circ} \mathrm{C} / 24 \mathrm{~h}$. Região da superfície da amostra. Direção de laminação paralela à direção vertical. 


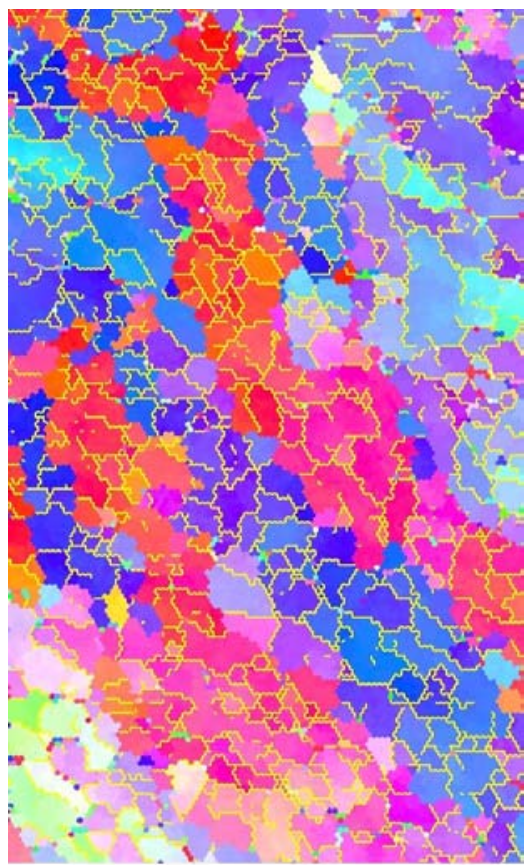

$20.00 \mu \mathrm{m}=20$ steps
Color Coded Map Type: Inverse Pole Figure [001]

Aluminum

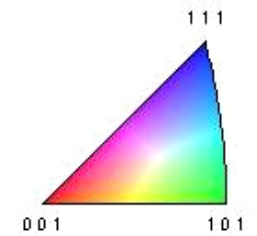

Boundaries: CSL

$\underline{\text { Sigma }} \frac{\text { Tolerance }}{15.00} \frac{\text { Fraction Volume }}{0.614} \frac{0.0228}{0.014}$ $\begin{array}{lll}\text { summary - } & 0.614 & 0.0228\end{array}$

a)

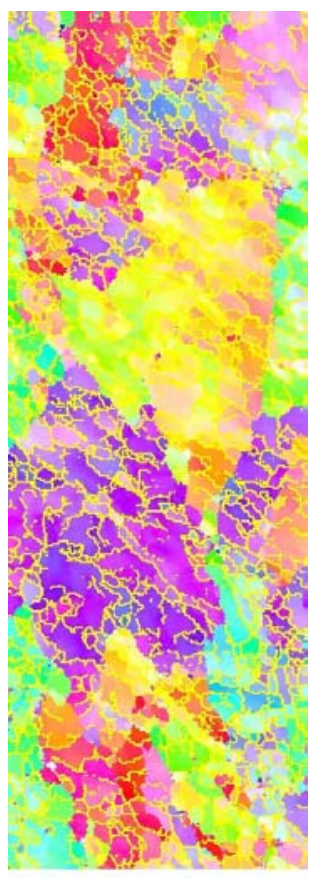

$30.00 \mu \mathrm{m}=30$ steps
Color Coded Map Type: Inverse Pole Figure [001]

Aluminum

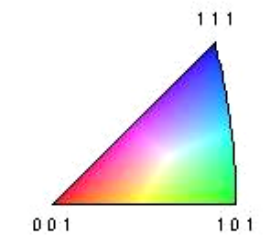

$\frac{\text { Sigma }}{1} \frac{\text { Tolerance }}{15.00} \frac{\text { Fraction }}{0.763} \frac{\text { Volume }}{0.0228}$
summary $0.763 \quad 0.0228$
Boundaries: CSL

b) 


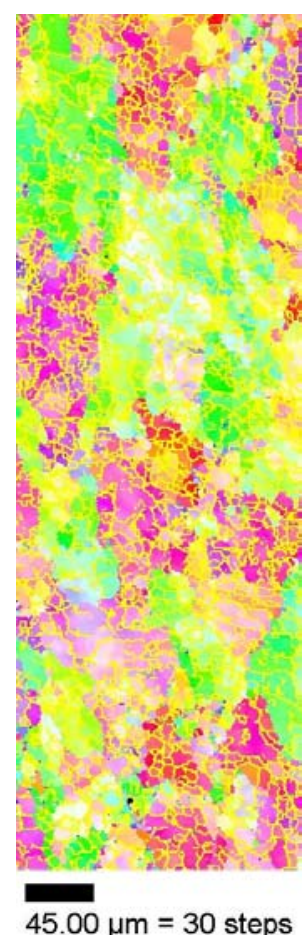

Color Coded Map Type: Inverse Pole Figure [001]

Aluminum

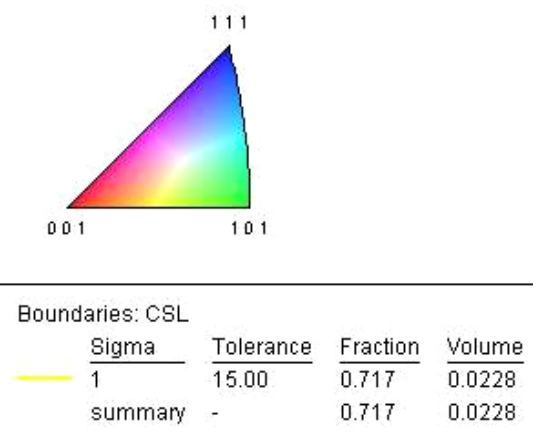

c)

Figura 78 - Análise de EBSD ao longo da espessura para determinar CSL da amostra caster bruta de fundição: a) superfície da amostra; b) na região $1 / 4$ de espessura; c) na região $1 / 2$ de espessura. Direção de laminação paralela à direção vertical.

A força motriz para a recristalização, em ligas supersaturadas e com presença de precipitados, é dada por [Hornbogen e Köster, 1978]:

$P=P_{D}-P_{Z}=\frac{2 \gamma_{S B}}{d}-\frac{3 F_{V} \cdot \gamma_{G B}}{2 r}$

onde, $\mathrm{P}_{\mathrm{D}}$ é a força motriz devido a energia dos contornos de diâmetro $\mathrm{d}, \mathrm{P}_{\mathrm{Z}}$ é a força retardadora (efeito Zener) devido a fração volumétrica de partículas $F_{\mathrm{V}}$ de raio $\mathrm{r}$, e $\gamma_{\mathrm{SB}}$ e $\gamma_{\mathrm{GB}}$ são energias dos contornos de subgrãos e de contornos de alto ângulo, respectivamente. A expressão para o efeito retardador Zener baseia-se na dipersão de partículas aleatoriamente distribuídas. Quando as partículas estão preferencialmente dispersas em contornos de baixo e de alto ângulo, este efeito pode ser maior nestes locais [Daaland, 1996]. Em ligas comerciais Al-Mn, os dispersóides precipitam preferencialmente na microestrutura deformada, em subcontornos ou nas discordâncias isoladas, levando a um considerável 
aumento na força retardadora [Tangen et al, 2002]. Isto indica que se a precipitação ocorrer simultaneamente com a recristalização, o processo de recristalização poderá ser fortemente retardado devido à precipitação de dispersóides. A variação da microdureza Vickers em função da temperatura apresentada na Figura 79 confirma este efeito. Pode-se verificar que houve atraso da recristalização para as amostras que não passaram por tratamento térmico de homogeneização antes da laminação a frio. Análise da microestrutura obtida por microscópio eletrônico de transmissão (Figura 80) nos revela que ocorreu precipitação durante tratamento térmico $\left(300^{\circ} \mathrm{C} / 1 \mathrm{~h}\right)$ que efetivamente atrasou a recristalização. Portanto, o tratamento térmico de homogeneização, além de causar o amolecimento do material devido à redução de defeitos cristalinos, causa também a precipitação. Os precipitados formados durante tratamento térmico de homogeneização não foram identificados, mas devem ser ricos em manganês, pois este é o soluto que permanece parcialmente em solução sólida após o processamento caster. Este aspecto será discutido em detalhes no item 4.8.

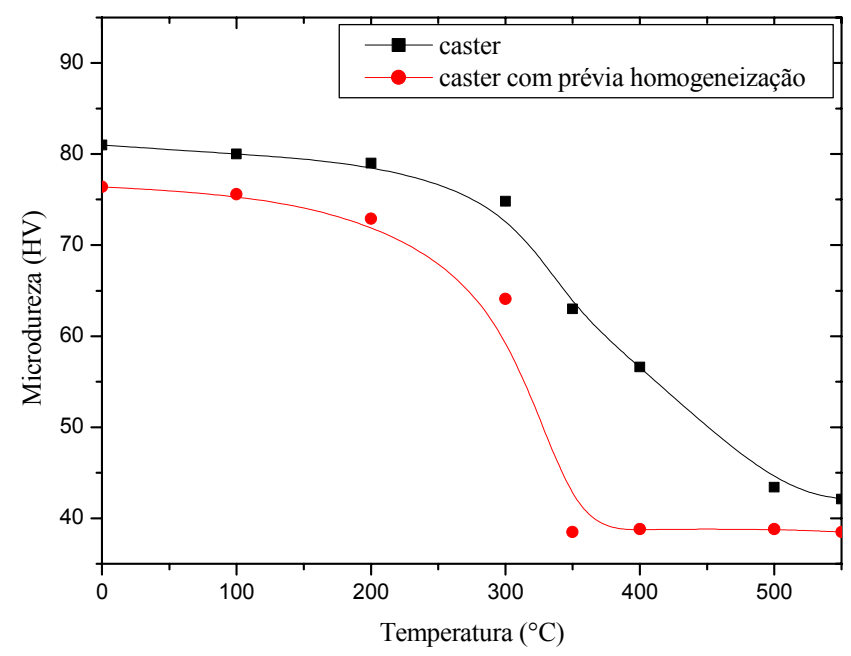

Figura 79 - Variação da microdureza Vickers em função da temperatura de duas condições: caster e caster com prévia homogeneização. A designação caster se refere à amostra no estado bruto de fundição. 


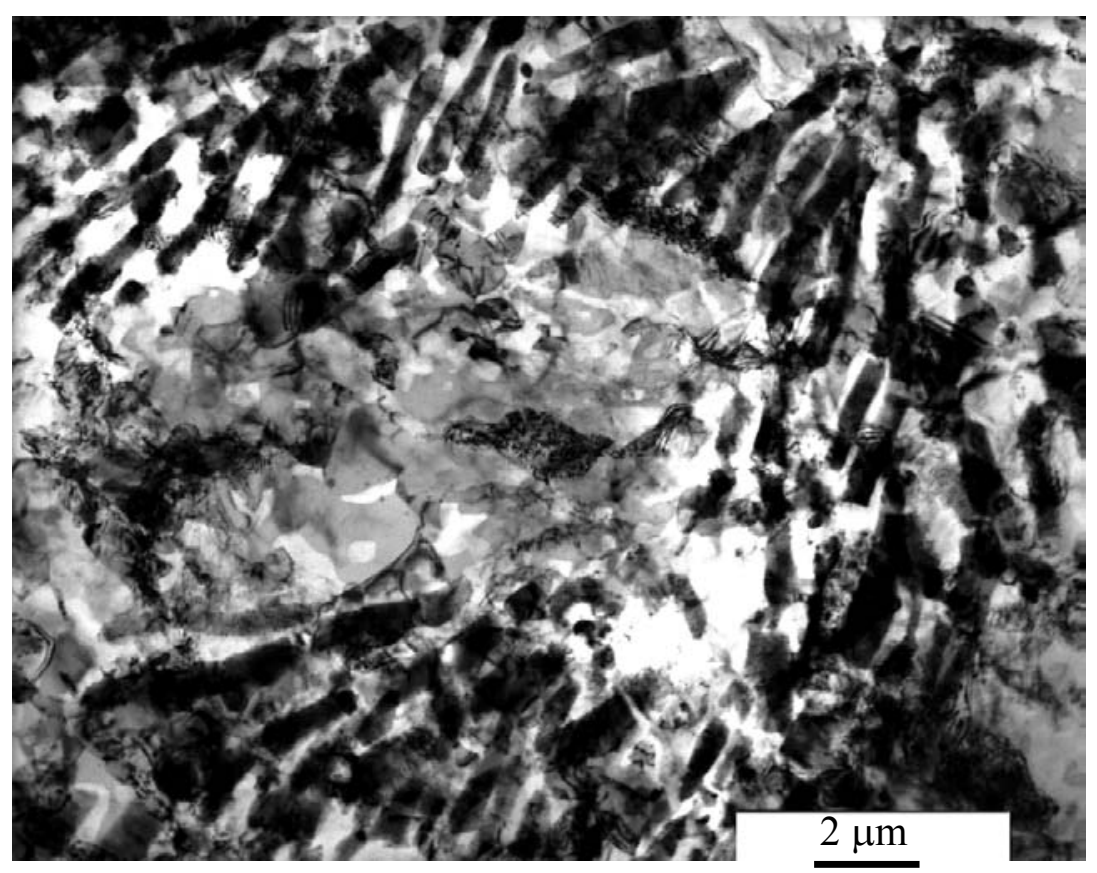

Figura 80 - Microestrutura da amostra caster recozida a $300^{\circ} \mathrm{C} / 1 \mathrm{~h}$ (após $91 \%$ de redução, laminada sem tratamento térmico prévio de homogeneização), microscopia eletrônica de transmissão. Amostra afinada eletroliticamente com solução contendo ácido perclórico.

Comparando-se as Figuras 81a e 81b (micrografias obtidas com o mesmo aumento), nota-se a diferença na microestrutura final das duas condições. A amostra que foi homogeneizada antes da laminação apresentou grãos menores (na ordem de 80-100 ㅆm), enquanto a amostra que não foi homogeneizada os grãos estão maiores (na ordem de 200 $\mu \mathrm{m})$. A comparação entre estas micrografias, mostra nitidamente que o tratamento térmico de homogeneização, além de acelerar a posterior recristalização estática, causa apreciável refino de grão. 


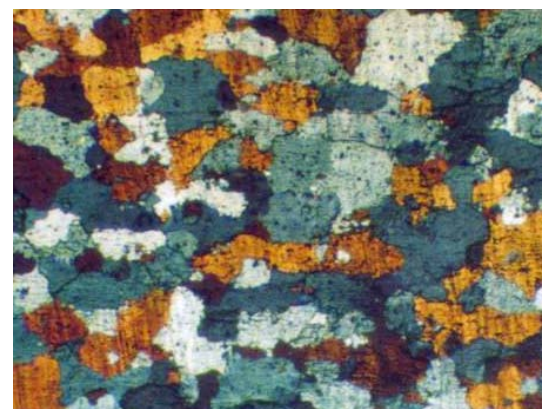

a)

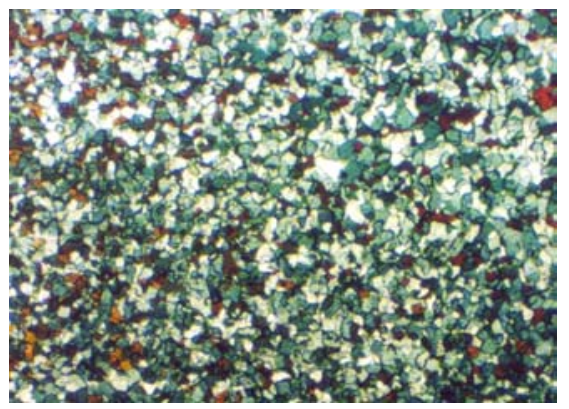

b)

Figura 81 - Microestrutura da amostra caster recozida a $500^{\circ} \mathrm{C} / 1 \mathrm{~h}$, após $91 \%$ de redução. Microscopia óptica com luz polarizada. Amostra anodizada com solução contendo ácido fluobórico. Direção de laminação paralela à direção horizontal. a) laminada sem tratamento térmico prévio de homogeneização; b) laminada com tratamento térmico prévio de homogeneização.

Com o objetivo de se analisar e comparar a textura das duas chapas laminadas, amostras foram retiradas, preparadas e levadas ao difratômetro Rigaku DMAX-2000 com goniômetro de textura horizontal. Nas Figuras 82 e 83 são mostradas as figuras de pólo 111 das duas chapas. Na amostra caster, observa-se que a amostra possui simetria, enquanto na amostra caster homogeneizada, não há qualquer simetria. Isto pode ter sido causado pelo acentuado crescimento de grão da amostra, que ocorreu durante homogeneização.

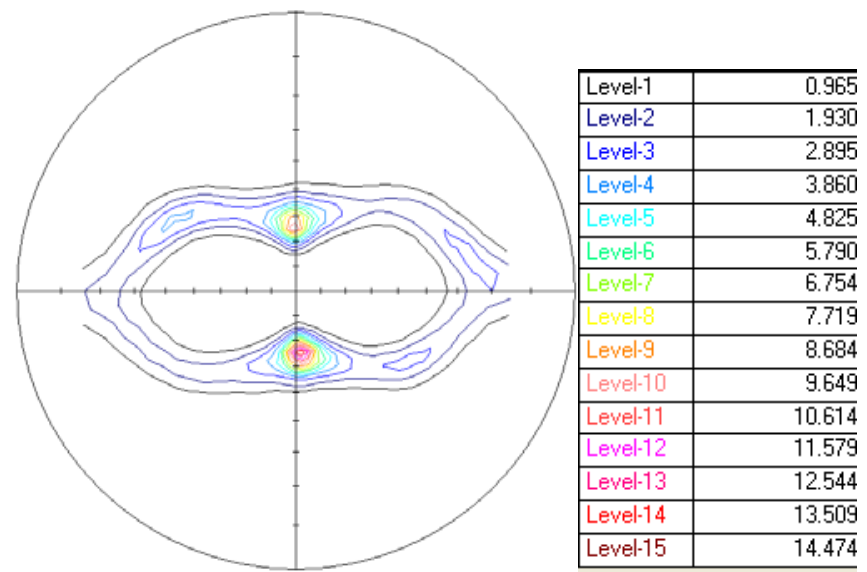

Figura 82 - Figura de pólo 111 da amostra caster com 91\% de redução, laminada sem tratamento térmico prévio de homogeneização. 


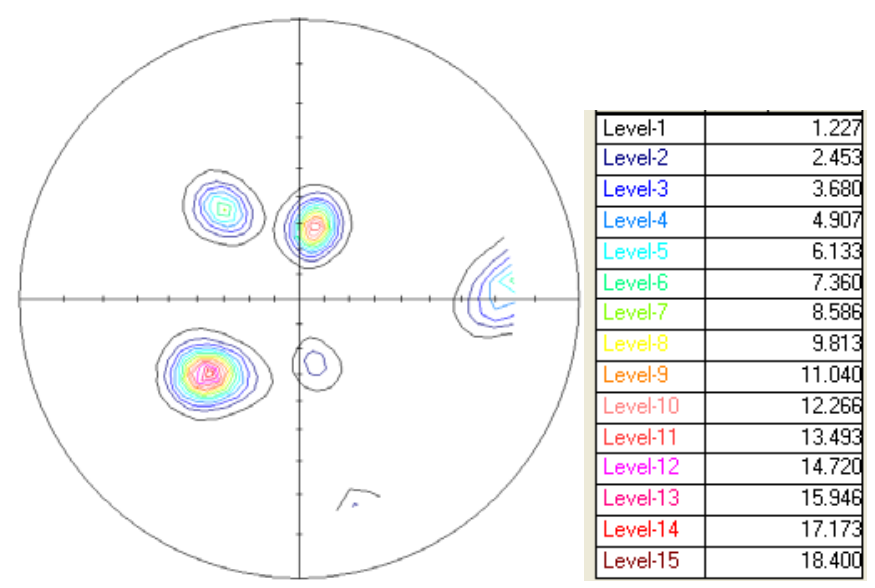

Figura 83 - Figura de pólo 111 da amostra caster com 91\% de redução, laminada sem tratamento térmico prévio de homogeneização.

Como a Figura de pólo (FP) da caster homogeneizada não possui simetria não é possível gerar FDO, mas pela intensidade da FP, nota-se que há textura. Para a amostra caster foi possível gerar FDO que é apresentada na Figura 84. Foi verificada a presença de três componentes típicas de laminação do alumínio: $\{011\}<211>$, conhecida como tipo latão, de maior intensidade, $\{123\}<634>$, conhecida como tipo S e $\{112\}<111>$, conhecida como tipo cobre.

As amostras que sofreram tratamento térmico de $500^{\circ} \mathrm{C} / 1 \mathrm{~h}$ após $91 \%$ de redução (caster e caster homogeneizada) também foram analisadas por EBSD, pois não foi possível gerar FP, por difração de raios $\mathrm{X}$ pela dificuldade encontrada devido ao tamanho de grão grande das amostras. Uma limitação da técnica difração de raios X para determinação de textura é que para tamanho de grão acima de $50 \mu \mathrm{m}$ a técnica passa a ser inviável.

A Figura 85 mostra o mapeamento de orientações e a FP gerados pelas medidas da amostra caster sem prévia homogeneização após 91\% de redução e tratamento térmico de $500^{\circ} \mathrm{C} / 1 \mathrm{~h}$. Realizaram-se cinco varreduras com o mesmo número de pontos. Essas cinco varreduras foram somadas para poder gerar as FP's. Por meio da análise da FP nota-se a presença da componente $\{113\}<\overline{1} 10>$. Esta componente pertence à fibra DL (direção de laminação) em coordenadas de Bunge (FDO). Na Figura 86 encontram-se o mapeamento de orientação, FP's e FDO obtidos por EBSD da amostra caster com prévia homogeneização após $91 \%$ de redução e tratamento térmico de $500^{\circ} \mathrm{C} / 1 \mathrm{~h}$. Observa-se a predominância da componente cubo, típica textura de recristalização. 


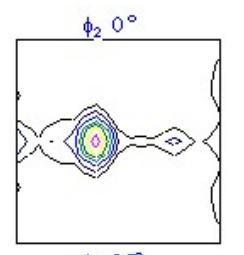

$\phi_{2} 25^{\circ}$

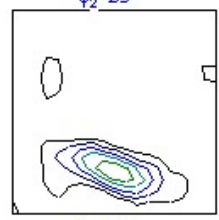

$\phi_{2} 50^{\circ}$
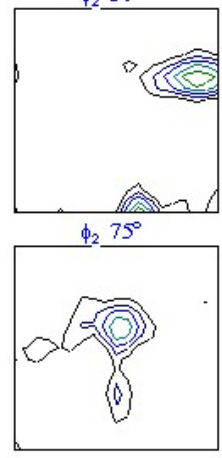

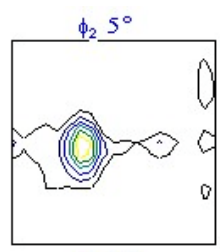

$\phi_{2} 30^{\circ}$

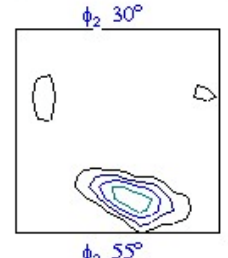

$\phi_{2} 55^{\circ}$
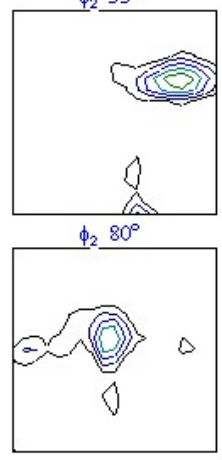

$\phi_{2} 10^{\circ}$

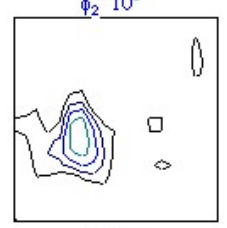

$\phi_{2} 35^{\circ}$

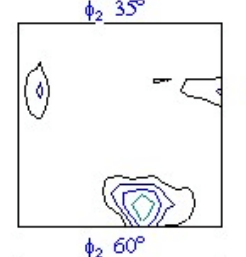

$\phi_{2}$
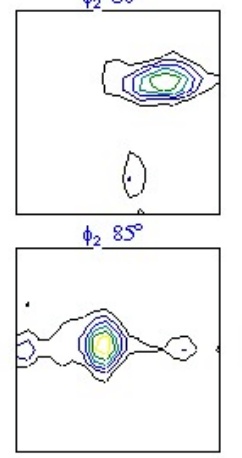

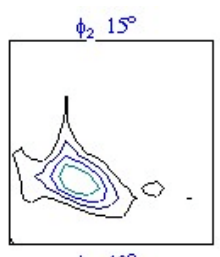

$\phi_{2} 40^{\circ}$
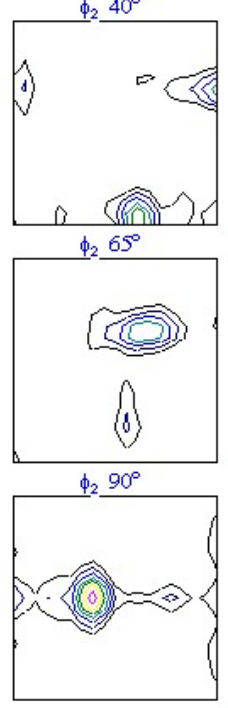
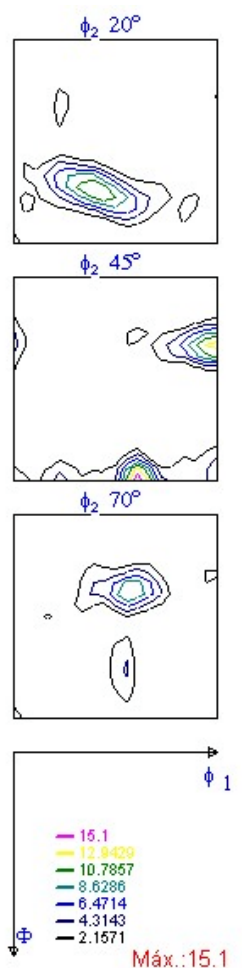

Figura 84 - ODF da amostra caster sem prévia homogeneização após 91\% de redução.

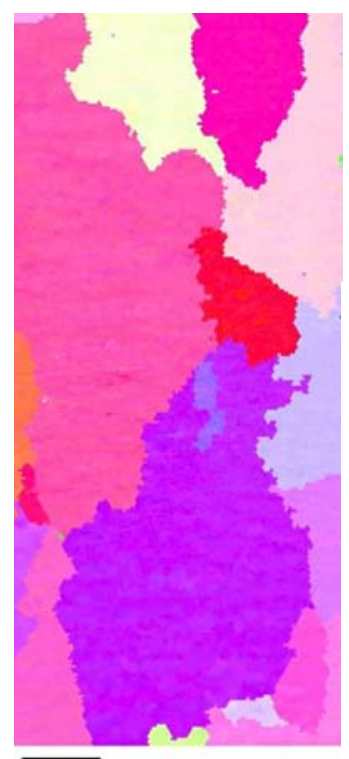

$225.0 \mu \mathrm{m}=25$ steps

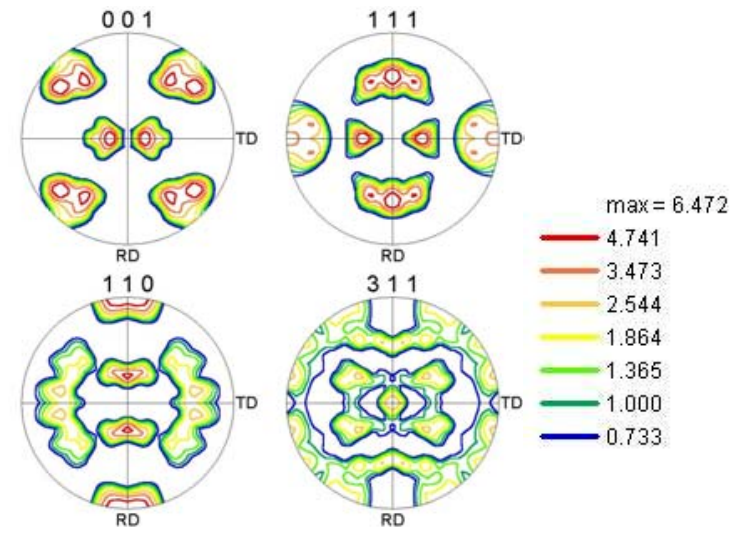

Figura 85 - Mapeamento de orientação e FP's obtidas por EBSD da amostra caster sem prévia homogeneização após $91 \%$ de redução e tratamento térmico de $500^{\circ} \mathrm{C} / 1 \mathrm{~h}$. Direção de laminação paralela à direção vertical. 

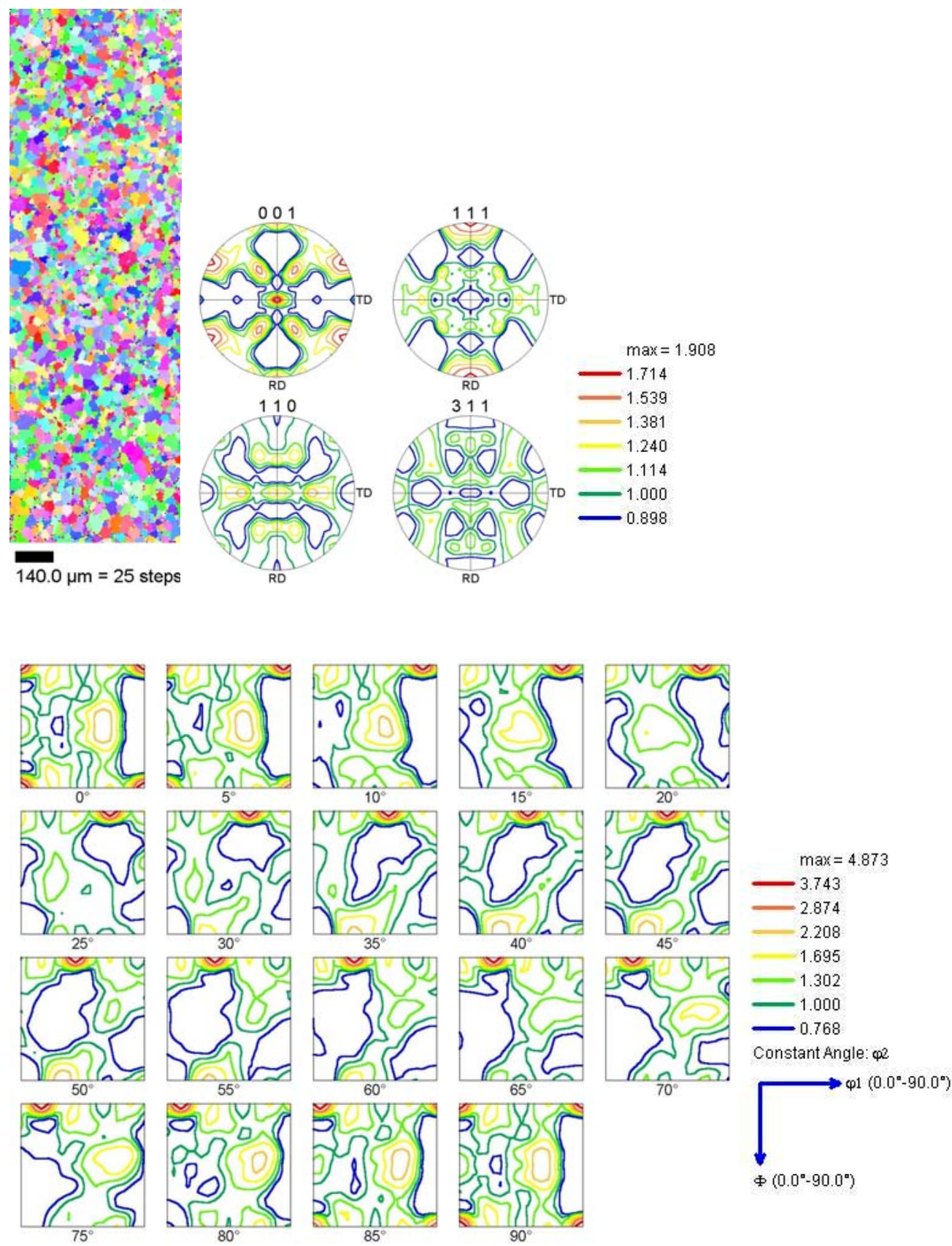

$\Phi\left(0.0^{\circ}-90.0^{\circ}\right)$

Figura 86 - Mapeamento de orientação, FP's e FDO obtidos por EBSD da amostra caster com prévia homogeneização após $91 \%$ de redução e tratamento térmico de $500^{\circ} \mathrm{C} / 1 \mathrm{~h}$. Direção de laminação paralela à direção vertical. 


\subsection{Comparação entre as técnicas de EBSD e de difração de raios X}

Para a comparação entre os dados de EBSD e difração de raios X, foram utilizados dados obtidos na análise da amostra caster: análise na superfície da amostra. $\mathrm{O}$ parâmetro $\rho_{0, \mathrm{~N}}$ foi calculado em função do número de orientações medidas e a curva obtida é apresentada na Figura 87. Para o cálculo de $\rho_{0, \mathrm{~N}}$ e do índice $J$ com dados de EBSD, foi utilizado um programa desenvolvido por Marilene Morelli Serna e Eguiberto Galego (CCTM-IPEN-SP). A curva apresenta o comportamento esperado, as diferenças percentuais tendem a diminuir com o aumento do número de pontos. Na Figura 54 foi apresentada a FDO da amostra caster superfície obtida por difração de raios X e na Figura 60 foi apresentada a FDO da mesma amostra, mas feita por EBSD e calculada impondo-se a simetria ortorrômbica, com 151500 pontos medidos. Nota-se que não houve diferença significativa na principal componente de textura.

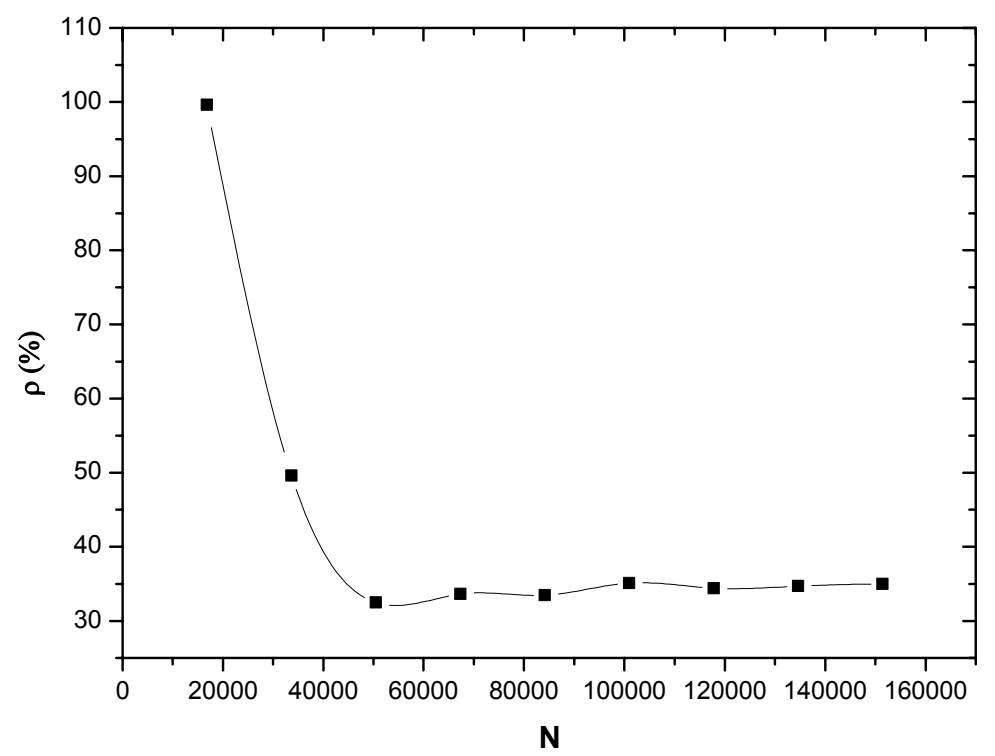

Figura 87 - Gráfico do parâmetro $\rho_{0, \mathrm{~N}}$ calculado em função do número de orientações medidas, dados da amostra caster superfície. 


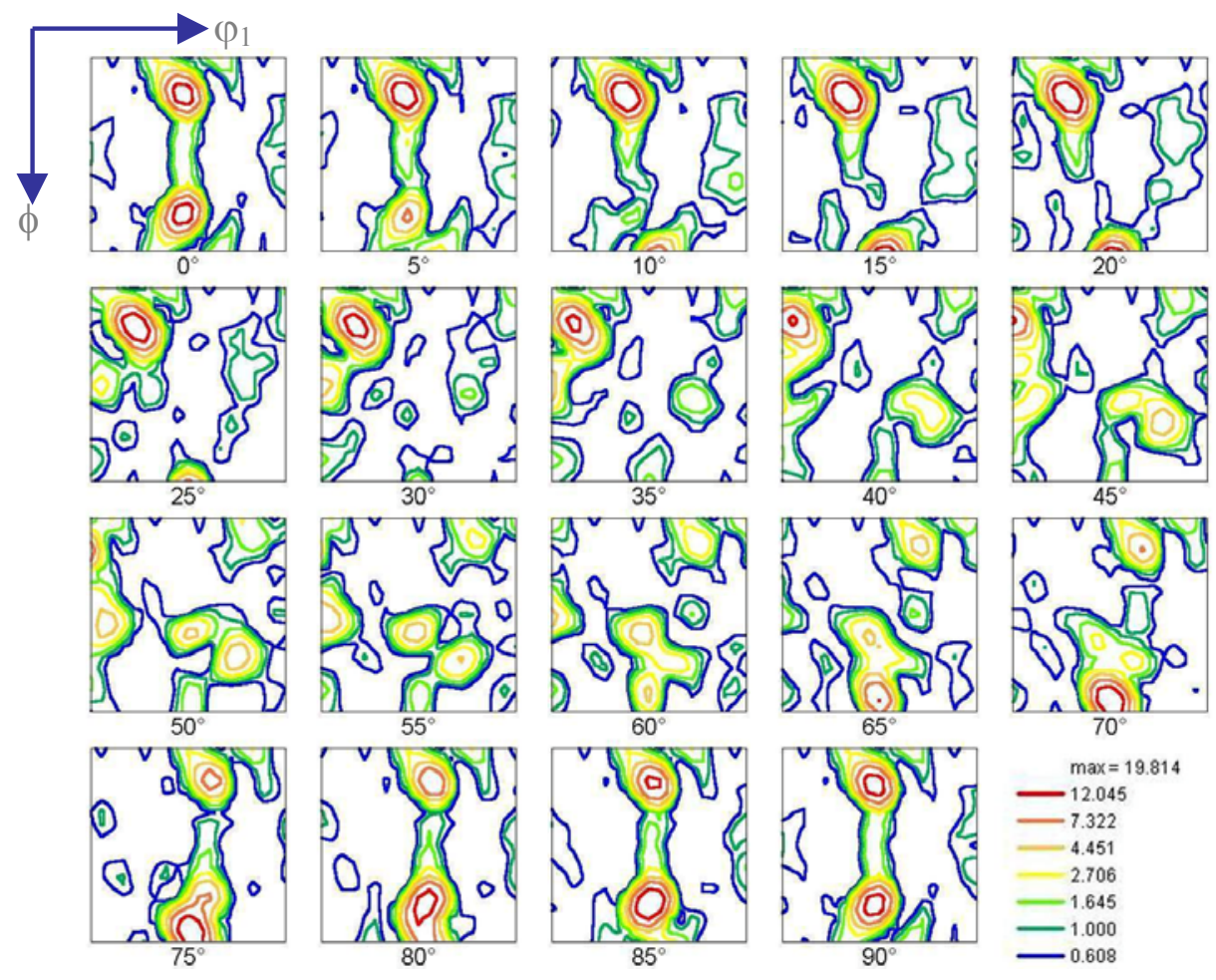

Figura 88 - FDO (EBSD) da amostra caster superfície a partir de 17000 pontos.

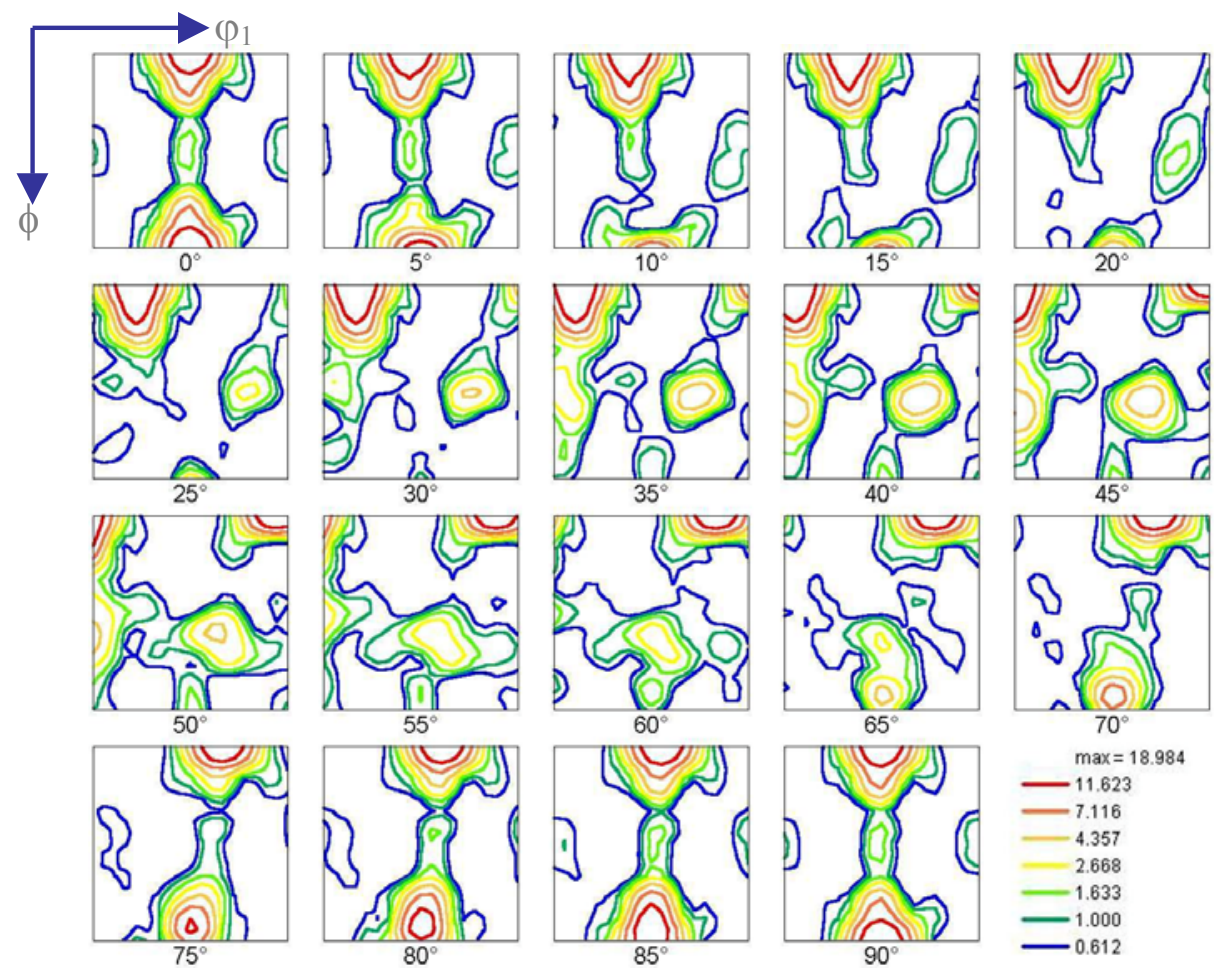

Figura 89 - FDO (EBSD) da amostra caster superfície a partir de 50500 pontos. 
Para representar a intensidade de textura de um material utiliza-se o índice $\mathrm{J}$ proposto por Bunge [1982]. Para amostras sem textura $\mathrm{J}=1$ e para um monocristal $\mathrm{J} \rightarrow \infty$. E uma grande diferença encontrada está no índice J calculado. Pela análise por EBSD, com 151500 pontos, foi encontrado $\mathrm{J}=3,07$ e pela análise de difração de raios $\mathrm{X}, \mathrm{J}=148,9$.

Nas Figuras 88 e 89 estão as FDO's da amostra caster superfície por EBSD a partir de 17000 pontos e a partir de 50500 pontos, respectivamente. Portanto, a Figura 88 referese a FDO do primeiro ponto do gráfico apresentado na Figura 87 e a Figura 89 refere-se a FDO do terceiro ponto, onde o valor do parâmetro $\rho_{0, \mathrm{~N}}$ tende a tornar constante. Pode-se notar que a análise apenas da Figura 88 gera erro, pois neste caso há grande diferença entre a componente de textura encontrada e a componente cubo rodado encontrada por difração de raios X. No entanto, a FDO da Figura 89 já seria suficiente para analisar a textura. 


\subsection{Técnicas de extração de precipitados}

A extração de precipitados em ligas de alumínio é especialmente problemática, pois a maioria das partículas (compostos intermetálicos) presentes dissolve-se tão facilmente quanto a matriz de alumínio [Gupta, 1996]. Por outro lado, as vantagens analíticas que se obtém ao isolar as partículas da matriz [Padilha, 1983] justificam o esforço de se tentar desenvolver e aperfeiçoar a técnica para as ligas de interesse deste trabalho. Os trabalhos encontrados na literatura [Cogan et al, 1978; Hodgson, 1981; Sperry, 1955] sobre extração de precipitados nas ligas Al-Mn-Fe-Si não são numerosos, mas fornecem algumas informações relevantes. As seguintes soluções para dissolução da matriz foram testadas:

a) dissolução química em solução de iodo em metanol [Sperry, 1955];

b) dissolução eletrolítica em solução de ácido benzóico e hidroxiquinolina em clorofórmio e metanol [Cogan et al, 1978; Hodgson, 1981];

c) dissolução eletrolítica em solução de ácido perclórico, butil glicol, álcool etílico e água [Pimenta et al, 1986].

d) dissolução química em solução de fenol [Gupta, 1996].

\subsubsection{Método da dissolução química}

Para a dissolução química foram utilizados dois métodos diferentes. Foram utilizados o método da dissolução química em solução de iodo em metanol e o método da dissolução química em solução de fenol. Para o primeiro utilizou-se amostra proveniente do processo caster bruta de fundição. Para o segundo método utilizaram-se duas amostras: caster homogeneizada pela $\mathrm{CBA}\left(500^{\circ} \mathrm{C}\right.$ por $\left.12 \mathrm{~h}\right)$ e caster homogeneizado em forno tubular a $550^{\circ} \mathrm{C}$ por $120 \mathrm{~h}$.

$\mathrm{Na}$ primeira tentativa do método dissolução química em solução de iodo em metanol obteve-se uma quantidade muito pequena de precipitados $(0,0011 \mathrm{~g})$, o que inviabilizou a análise dos mesmos. Na segunda e na terceira tentativa, além da matriz alumínio, os precipitados também foram dissolvidos pela solução, com isso, o filtro não apresentava precipitado retido. $\mathrm{Na}$ quarta tentativa obtiveram-se melhores resultados, a quantidade de precipitados obtida foi de $0,0171 \mathrm{~g}$. 
A difração no filtro contendo precipitado foi feita $\operatorname{com} 2 \theta$ inicial $=15^{\circ}$ e $2 \theta$ final $=$ $120^{\circ}$, passo de $0,02^{\circ}$ e tempo de exposição de 1 segundo. A idéia inicial era fazer difração do filtro com precipitado e outra em um filtro limpo, desse modo, os picos do filtro seriam identificados e separados dos picos dos precipitados. O difratograma obtido é apresentado na Figura 90. Pela dificuldade de se identificar os picos dos precipitados que ficaram com intensidades muito baixas, optou-se por se retirar os precipitados do filtro para se fazer a difração. O difratograma do pó encontra-se na Figura 91.

Pela Figura 91 nota-se que no pó ainda há alumínio, provavelmente o tempo não foi suficiente ou a quantidade de solução não foi adequada para a diluição de toda a matriz. Como foi visto na Figura 34, a solução de iodo e metanol com o tempo começa a atacar não só o alumínio mas também os precipitados, portanto, aumentar o tempo não é uma solução adequada.

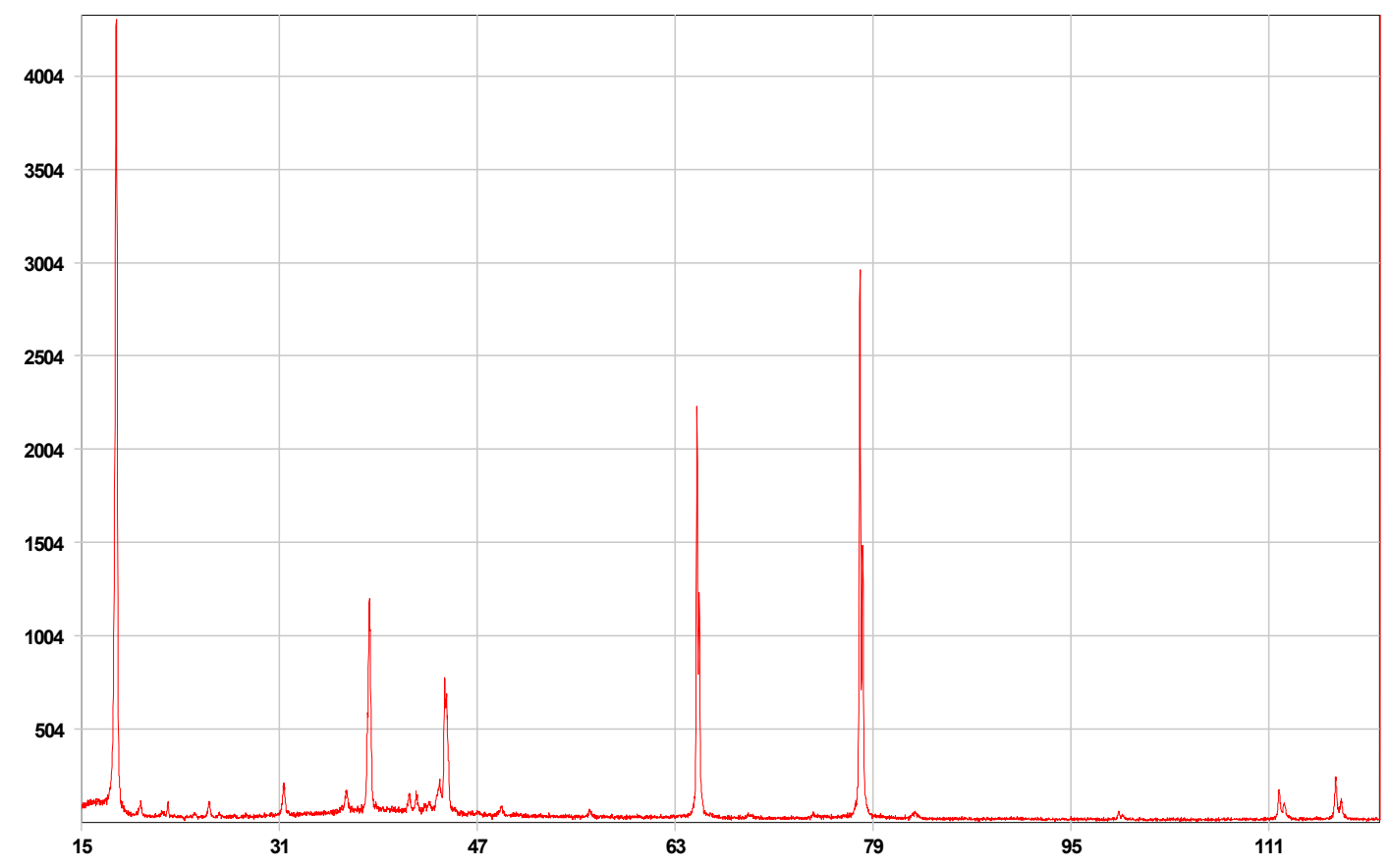

Figura 90 - Difratograma (utilizando-se tubo de cobre) do filtro de PTFE com resíduo extraído da amostra caster, pela dissolução química em solução de iodo e metanol. 


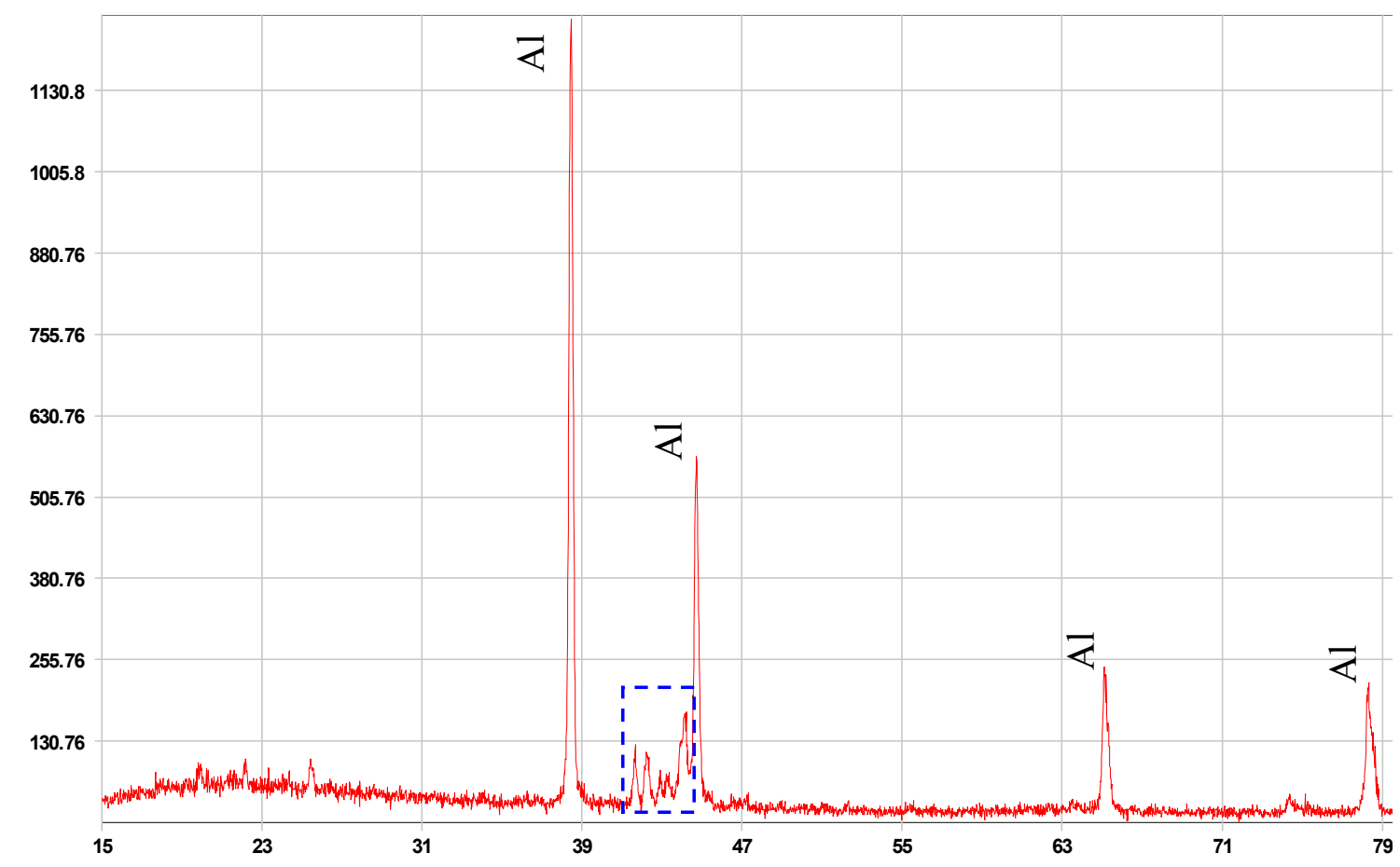

Figura 91 - Difratograma (utilizando-se tubo de cobre) do resíduo extraído da amostra caster, pelo método de dissolução química em solução de iodo e metanol.

Os picos de maior intensidade das fases $\mathrm{Al}_{6} \mathrm{Mn}$ e $\alpha$-AlMnSi estão entre o intervalo de $2 \theta 36^{\circ}$ e $46^{\circ}$, mostrado na Figura 91. A dificuldade encontrada está relacionada com o fato dos valores de distâncias interplanares e de $2 \theta$ serem muito similares nas duas fases.

Os picos das fases $\mathrm{Al}_{6} \mathrm{Mn}$ e $\alpha$-AlMnSi foram identificados com o auxílio das fichas JCPDS 06-0665 e 06-0669, respectivamente. Estas fichas não são muito recentes e no caso da ficha 06-0669 a estequiometria não foi considerada tão relevante. Estas fichas foram escolhidas pela concordância dos parâmetros de rede e estruturas cristalinas com as informações encontradas em literatura, conforme mostrado na Tabela 3.

Os picos das fases presentes no resíduo encontram-se muitos próximos na Figura 91, tornando difícil a identificação dos picos das fases no próprio difratograma. Portanto torna-se necessário descrever aqui os picos utilizados na análise. Para cálculo do parâmetro de rede da fase $\alpha$, cúbica, foram utilizados os picos de $2 \theta=43,9^{\circ}, 61,1^{\circ}$ e $74,4^{\circ}$. Para cálculo dos parâmetros de rede da fase $\mathrm{Al}_{6} \mathrm{Mn}$, ortorrômbica, foram utilizados os picos de $2 \theta=18^{\circ}, 20^{\circ}$ e $43,3^{\circ}$. Após identificação, os parâmetros de rede das fases foram calculados. Para a fase cúbica utilizou-se o método de Cohen [Cullity, 2001] e o valor 
obtido foi 1,266 nm. Para a fase ortorrômbica os valores obtidos foram: $\mathrm{a}=0,652 \mathrm{~nm}, \mathrm{~b}=$ 0,749 e c $=0,887 \mathrm{~nm}$.

Optou-se por fazer uma tentativa através da dissolução química com fenol [Gupta et al, 1996]. Esta dissolução foi feita em duas amostras, como já foi dito, caster homogeneizada pela $\mathrm{CBA}\left(500^{\circ} \mathrm{C}\right.$ por $\left.12 \mathrm{~h}\right)$ e caster homogeneizado em forno tubular a $550^{\circ} \mathrm{C}$ por $120 \mathrm{~h}$. Estas condições foram escolhidas propositalmente, para possibilitar o estudo da transformação da fase $\mathrm{Al}_{6} \mathrm{Mn}$, de estrutura ortorrômbica, na fase $\alpha$ - $\mathrm{Al}(\mathrm{Mn}, \mathrm{Fe}) \mathrm{Si}$, de estrutura cúbica.

Na Figura 92 encontra-se o difratograma do resíduo extraído na primeira tentativa de dissolução química com fenol, feita com a amostra caster homogeneizada a $500^{\circ} \mathrm{C}$ por $12 \mathrm{~h}$. Nota-se que ainda há o pico (111) do alumínio com $2 \theta=38,48^{\circ}$. O pico de maior intensidade é da fase $\mathrm{Al}_{6} \mathrm{Mn}$, plano (310), com $2 \theta=43,77^{\circ}$. Na Figura 93 encontra-se o difratograma da amostra homogeneizada a $550^{\circ} \mathrm{C}$ por $120 \mathrm{~h}$. Nota-se que não há presença de alumínio e o pico de maior intensidade é da fase $\alpha$ - $\mathrm{Al}(\mathrm{Mn}, \mathrm{Fe}) \mathrm{Si}$, plano (611), com $2 \theta=$ $44,10^{\circ}$. Observa-se também que a intensidade dos picos é bastante baixa. Portanto, o tratamento térmico de homogeneização a $550^{\circ} \mathrm{C}$ por $120 \mathrm{~h}$ causou a transformação da fase $\mathrm{Al}_{6} \mathrm{Mn}$ em $\alpha-\mathrm{Al}(\mathrm{Mn}, \mathrm{Fe}) \mathrm{Si}$, também conhecida como $6 \rightarrow \alpha$.

É importante esclarecer que o difratograma completo foi analisado, de $2 \theta=15^{\circ} \mathrm{a}$ $2 \theta=120^{\circ}$. Mas, para tornar mais simples a apresentação dos resultados, considerou-se conveniente mostrar apenas os difratogramas das varreduras mais lentas, de $2 \theta=36^{\circ}$ a $2 \theta=46^{\circ}$. 


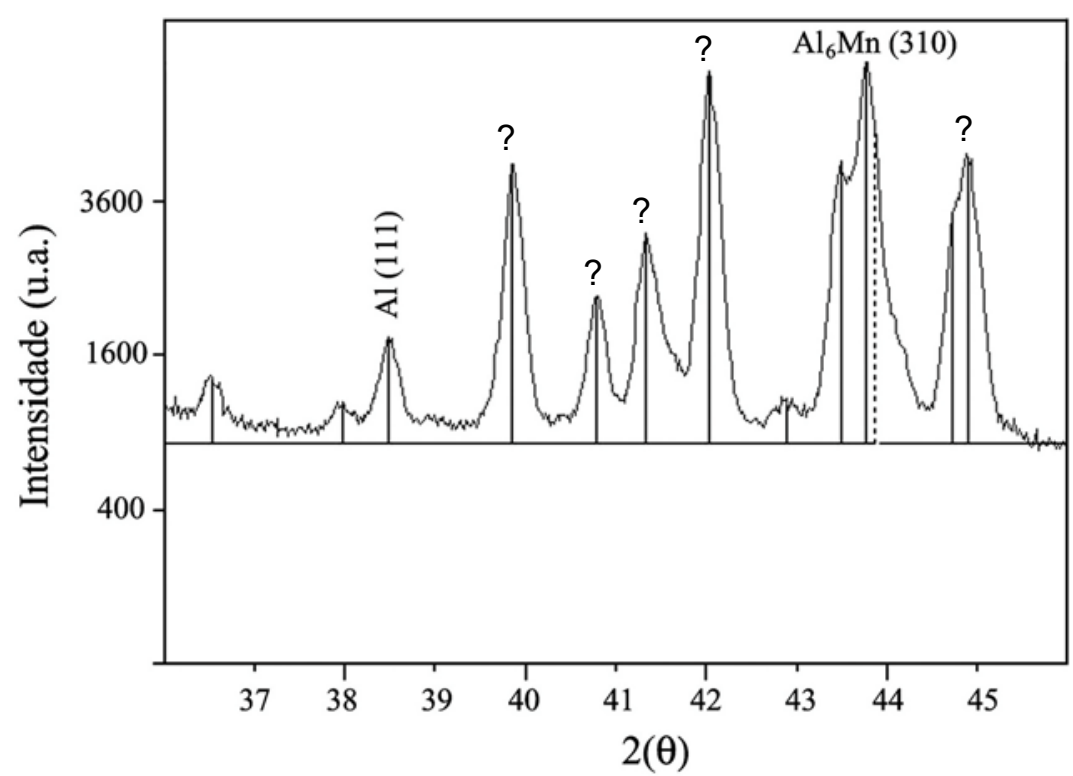

Figura 92 - Difratograma (utilizando-se tubo de cobre) do resíduo extraído de amostra homogeneizada a $500^{\circ} \mathrm{C}$ por $12 \mathrm{~h}$. Dissolução química por fenol. Varredura lenta com tempo de exposição de 10 segundos.

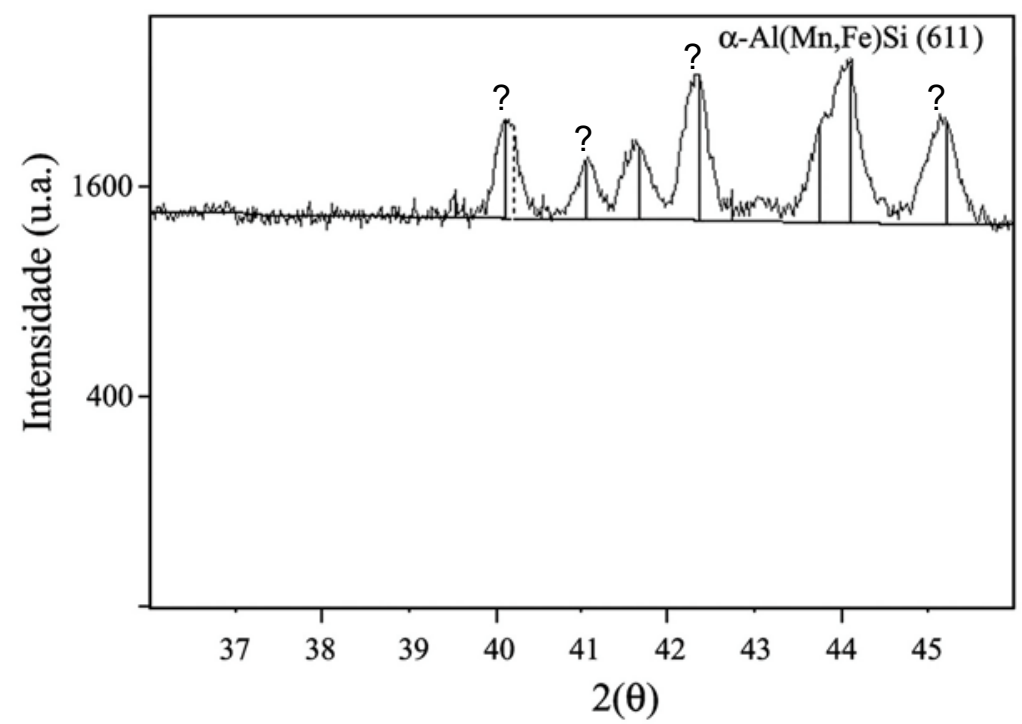

Figura 93 - Difratograma (utilizando-se tubo de cobre) do resíduo extraído de amostra homogeneizada a $550^{\circ} \mathrm{C}$ por $120 \mathrm{~h}$. Dissolução química por fenol. Varredura lenta com tempo de exposição de 10 segundos. 


\subsubsection{Método da dissolução eletrolítica}

Para esta técnica utilizaram-se duas amostras: uma proveniente do processo roll caster sem posterior tratamento térmico e outra homogeneizada pela $\mathrm{CBA}\left(500^{\circ} \mathrm{C}\right.$ por 12 horas). Na primeira amostra a quantidade de pó obtida foi de $0,0298 \mathrm{~g}$ e na segunda amostra $0,011 \mathrm{~g}$.

O difratograma resultante da primeira varredura da amostra caster, mostrada pela Figura 94, revela que há alumínio presente no pó. Entre $2 \theta=15^{\circ}$ e $2 \theta=31^{\circ}$ há uma região que sugere a presença de um material amorfo, que provavelmente, provém da resina utilizada para fixar o pó no suporte para a difração.

Na Figura 95, encontra-se o difratograma da varredura mais lenta da amostra caster, houve uma diminuição no ruído e foi possível diferenciar o que realmente era pico e o que era ruído.

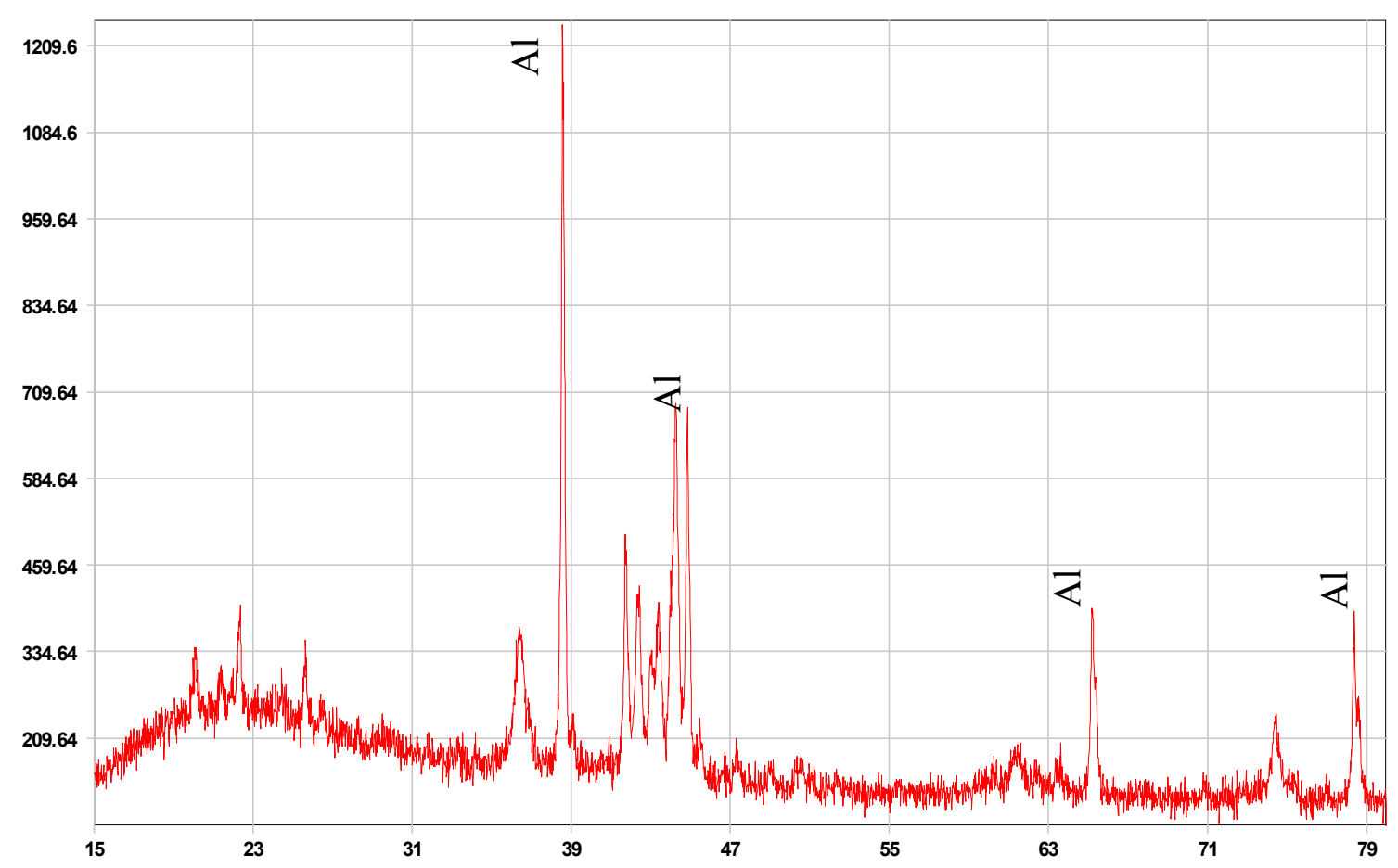

Figura 94 - Difratograma (utilizando-se tubo de cobre) do resíduo extraído da amostra caster pela dissolução eletrolítica com solução contendo ácido perclórico. 
Os picos das fases $\mathrm{Al}_{6} \mathrm{Mn}$ e $\alpha$-AlMnSi foram identificados também com o auxílio das fichas JCPDS 06-0665 e 06-0669, respectivamente, e são mostrados na Figura 95. Com

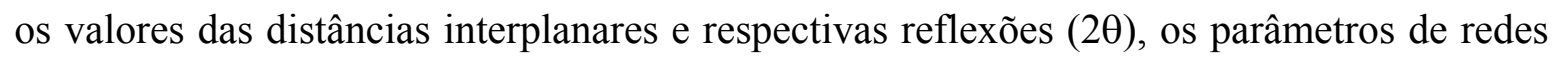
foram calculados. Para a fase cúbica utilizou-se o método de Cohen [Cullity, 2001] e o valor obtido foi 1,262 $\mathrm{nm}$. Para a fase ortorrômbica os valores obtidos foram: $\mathrm{a}=0,651 \mathrm{~nm}$, $\mathrm{b}=0,737$ e $\mathrm{c}=0,881 \mathrm{~nm}$. Valores muito próximos aos calculados com os dados da difração de precipitados extraídos pela dissolução química. Estes valores de parâmetros de rede estão em boa concordância com os valores encontrados na literatura e que foram mostrados na Tabela 3 [Hansen et al, 1995].

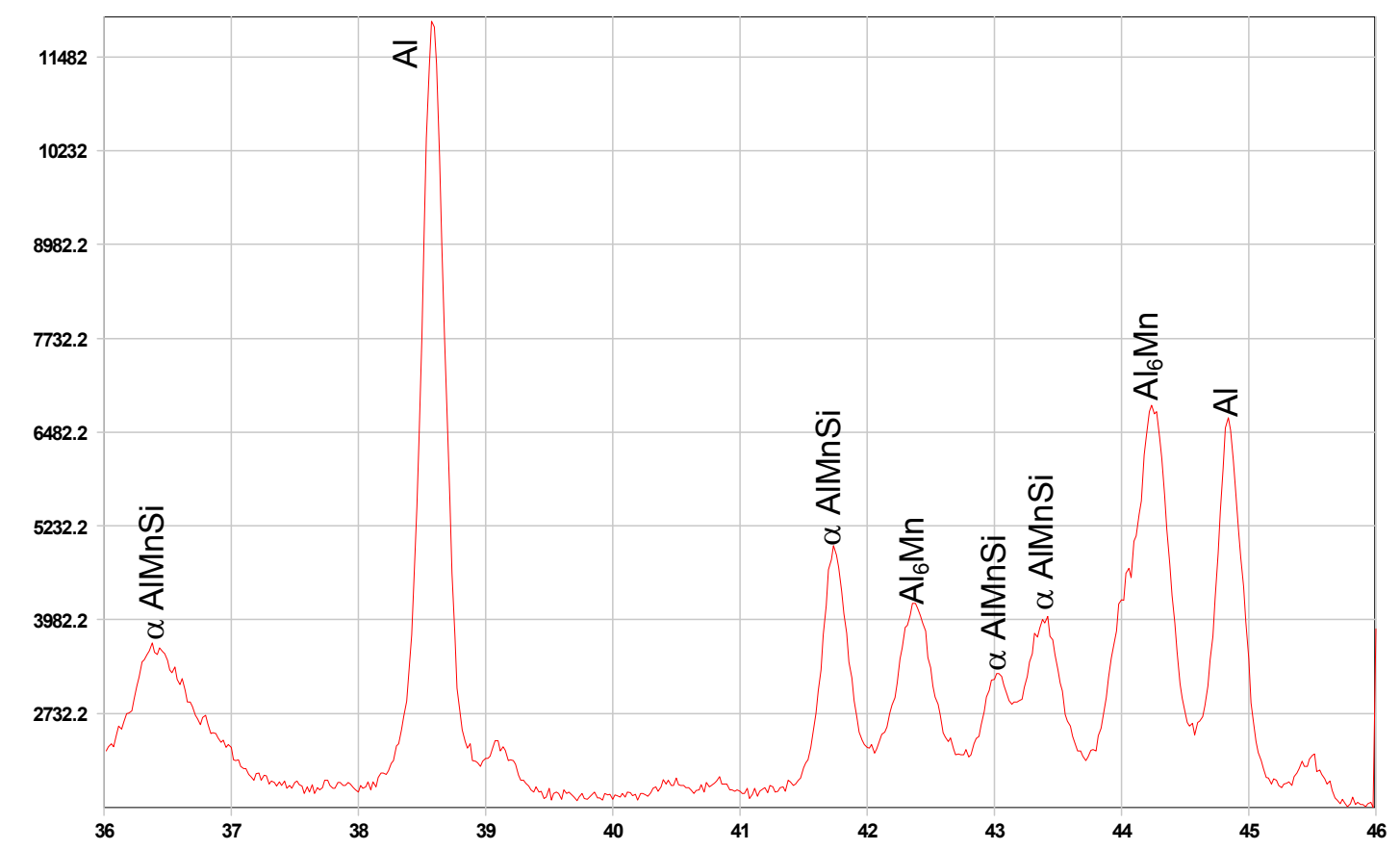

Figura 95 - Difratograma (utilizando-se tubo de cobre) do resíduo extraído da amostra caster pela dissolução eletrolítica com solução contendo ácido perclórico. Varredura lenta com tempo de exposição de 10 segundos. 


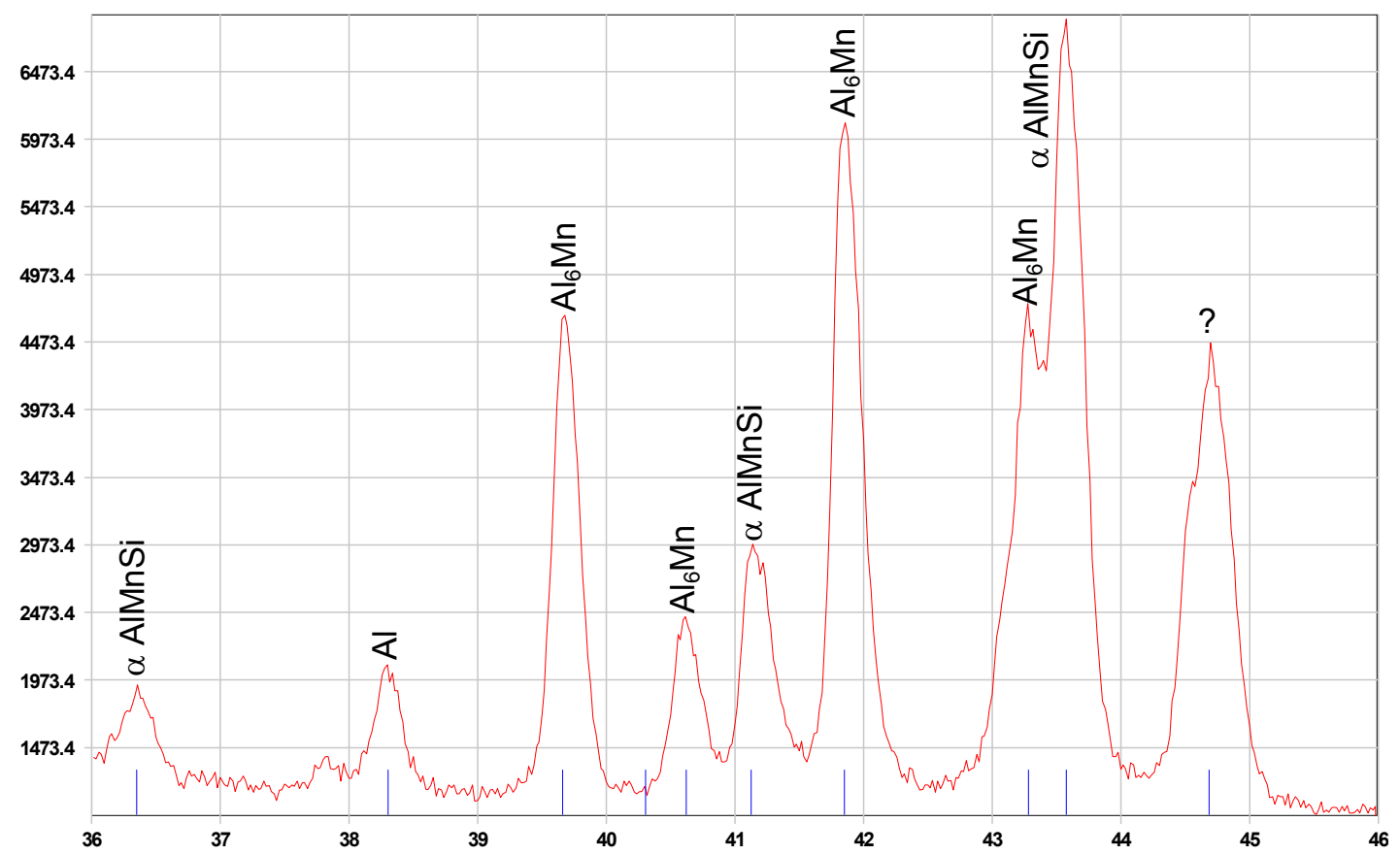

Figura 96 - Difratograma (utilizando-se tubo de cobre) do resíduo extraído da amostra caster homogeneizada a $500^{\circ} \mathrm{C}$ por 12 horas pela dissolução eletrolítica com solução contendo ácido perclórico. Varredura lenta com tempo de exposição de 10 segundos.

Na Figura 96 o difratograma feito com precipitados da amostra caster homogeneizada revela que ainda há alumínio no pó.

Outra solução foi utilizada pelo método eletrolítico: $15 \mathrm{~g}$ de oxina, $60 \mathrm{~g}$ de ácido benzóico, $60 \mathrm{ml}$ de clorofórmio, $165 \mathrm{ml}$ metanol. Foi o pior resultado obtido: ataque muito lento e houve reação com o filtro, impossibilitando a pesagem para se obter a quantidade de precipitados e análise por difração de raios $\mathrm{X}$. Na Tabela abaixo são comparados os resultados dos quatro métodos utilizados. 
Tabela 10 - Comparação entre os métodos de extração de precipitados.

\begin{tabular}{|c|c|c|}
\hline Método & $\begin{array}{l}\text { Velocidade de } \\
\text { dissolução }\end{array}$ & Resultados \\
\hline $\begin{array}{l}\text { Ataque eletrolítico } \\
\text { com ácido } \\
\text { perclórico }\end{array}$ & $0,8 \mathrm{~g} / \mathrm{h}$ & Não dissolve todo o alumínio \\
\hline $\begin{array}{l}\text { Ataque eletrolítico } \\
\text { com oxina }\end{array}$ & $0,2 \mathrm{~g} / \mathrm{h}$ & $\begin{array}{llrrr}\text { Houve } & \text { reação } & \text { com o } & \text { filtro, } \\
\text { necessita } & \text { de } & \text { sistema } & \text { de } \\
\text { centrifugação } & & & \end{array}$ \\
\hline $\begin{array}{l}\text { Ataque químico } \\
\text { com iodo }\end{array}$ & $\begin{array}{l}\text { 0,02(sem } \\
\text { agitação) a } \\
0,04 \mathrm{~g} / \mathrm{h} \quad \text { (sob } \\
\text { agitação) }\end{array}$ & Dissolve também os precipitados \\
\hline $\begin{array}{l}\text { Ataque químico } \\
\text { com fenol }\end{array}$ & $0,02 \mathrm{~g} / \mathrm{min}$ & $\begin{array}{l}\text { Ataque rápido (a reação dura de } 10 \\
\text { a } 15 \text { minutos); } 1^{\circ} \text { tentativa não } \\
\text { dissolveu todo o alumínio; } 2^{\circ} \\
\text { tentativa dissolveu todo o alumínio }\end{array}$ \\
\hline
\end{tabular}




\subsection{Estudo da transformação do precipitado $\mathrm{Al}_{6} \mathrm{Mn}$ durante tratamentos de homogeneização}

A homogeneização em produtos fundidos produz uma dispersão de partículas grossas e, no caso da liga 3003, reduz a concentração de Mn em solução sólida antes da laminação para se obter um produto final de grãos finos. Finos dispersóides e partículas

primárias grandes têm influência na recristalização, na textura e no comportamento mecânico de ligas de alumínio. Durante tratamento térmico, a composição de partículas primárias muda, a fase $\mathrm{Al}_{6}(\mathrm{Mn}, \mathrm{Fe})$ se transforma em $\alpha-\mathrm{Al}(\mathrm{Mn}, \mathrm{Fe}) \mathrm{Si}$. No presente capítulo serão apresentados resultados das análises de dois diferentes tratamentos térmicos. Primeiro foi analisado o tratamento utilizado pela empresa CBA - Companhia Brasileira de Alumínio (homogeneização a $500^{\circ} \mathrm{C}$ por $12 \mathrm{~h}$ ). No segundo subitem a transformação da fase foi analisada por meio de tratamentos térmicos de homogeneização realizados em laboratório, na temperatura de $550^{\circ} \mathrm{C}$, em tempos variados.

\subsubsection{Caracterização do tratamento térmico de homogeneização de $500^{\circ} \mathrm{C}$ por $12 \mathrm{~h}$}

Na Figura 97 tem-se a microestrutura da amostra caster após homogeneização $\left(600^{\circ} \mathrm{C}\right.$ por $8 \mathrm{~h}$ para que todas as bobinas cheguem a $500^{\circ} \mathrm{C}$ e o tratamento final é a $500^{\circ} \mathrm{C}$ por $12 \mathrm{~h}$ ). Pode-se perceber 3 tipos de partículas distintas no caster homogeneizado: partículas claras (da cor da matriz) globulares, partículas escuras também globulares e partículas menores escuras. $\mathrm{Na}$ microscopia ótica as partículas claras são $\mathrm{Al}_{6} \mathrm{Mn}$ e as escuras são $\alpha \mathrm{Al}(\mathrm{Mn}, \mathrm{Fe}) \mathrm{Si}$. Na Figura 98 encontra-se a mesma amostra, analisada em microscópio eletrônico de varredura com elétrons retroespalhados. Nota-se uma distribuição mais homogênea dos precipitados e, em relação à morfologia, os precipitados encontram-se mais esferoidizados após homogeneização, em comparação com a amostra bruta de fundição. Segundo Li [2002] na microscopia eletrônica de varredura com elétrons retroespalhados as partículas escuras são $\mathrm{Al}_{6} \mathrm{Mn}$ e as partículas claras são $\alpha-\mathrm{Al}(\mathrm{Mn}, \mathrm{Fe}) \mathrm{Si}$.

Com auxílio de imagens obtidas por microscopia eletrônica de varredura, elétrons retroespalhados (como mostra a Figura 98), foi possível medir a fração volumétrica de precipitados para a amostra homogeneizada $\left(500^{\circ} \mathrm{C}\right.$ por $\left.12 \mathrm{~h}\right)$ na região $1 / 2$ da espessura. 
Foram realizadas 15 medidas por amostra. A Tabela 11 compara os valores de fração volumétrica da amostra homogeneizada com o valor do estado bruto de fundição, ambos determinados à $1 / 2$ espessura.

Tabela 11 - Fração volumétrica de precipitados para amostra homogeneizada a $500^{\circ} \mathrm{C}$ por 12 horas e no estado bruto de fundição ( $1 / 2$ espessura).

\begin{tabular}{|c|c|}
\hline Condição & Fração Volumétrica (\%) \\
\hline $\begin{array}{c}\text { Homogeneizado } \\
\left.\mathbf{( 5 0 0}^{\circ} \mathbf{C} / \mathbf{1 2 h}\right)\end{array}$ & $8,6 \pm 0,4$ \\
\hline Bruto de fundição & $6,3 \pm 0,9$ \\
\hline
\end{tabular}

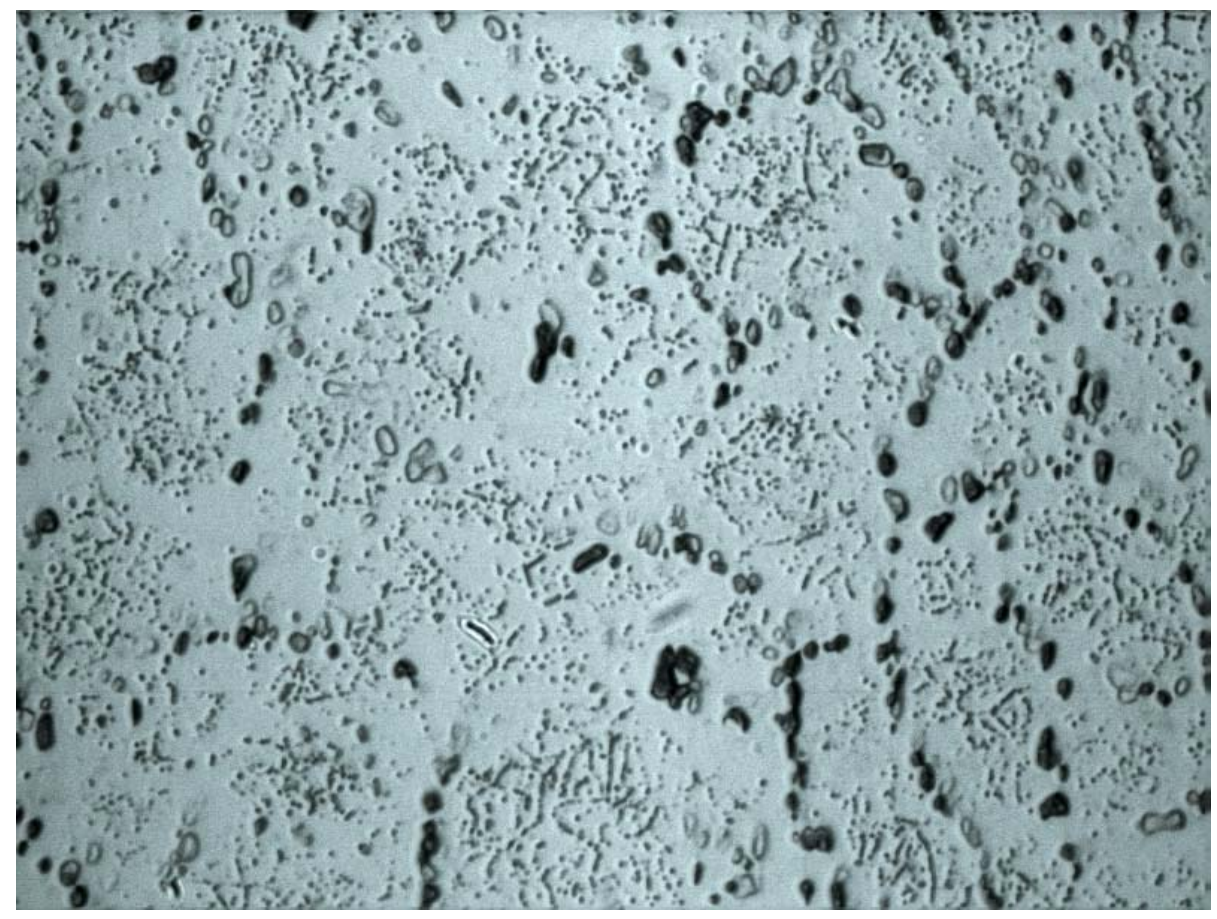

$20 \mu \mathrm{m}$

Figura 97 - Microestrutura da amostra caster homogeneizada a $500^{\circ} \mathrm{C}$ por 12 horas, microscopia óptica, ataque de solução $0,5 \%$ HF e em seguida solução aquosa de $\mathrm{KMnO}_{4} \cdot \mathrm{Na}_{2} \mathrm{CO}_{3}$. 

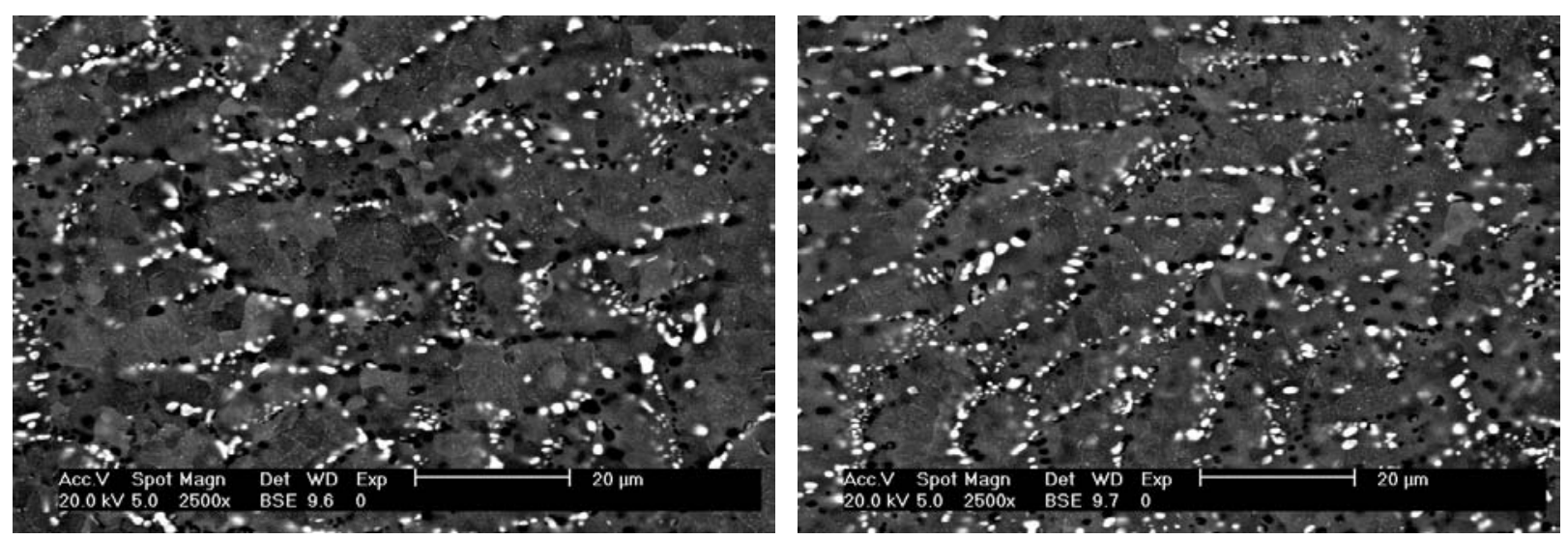

Figura 98 - Microestrutura da amostra caster homogeneizada a $500^{\circ} \mathrm{C}$ por 12 horas, microscopia eletrônica de varredura, elétrons retroespalhados.

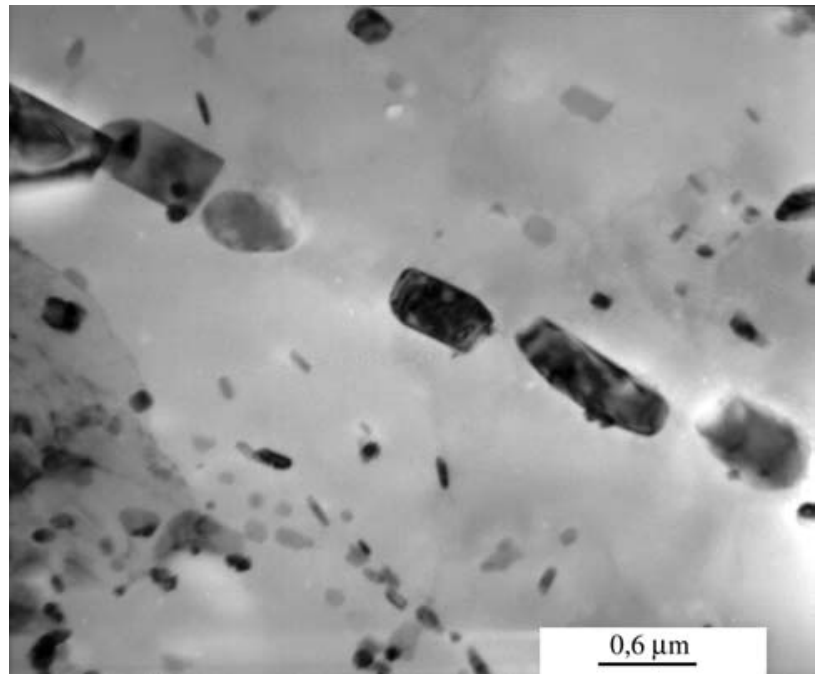

a)

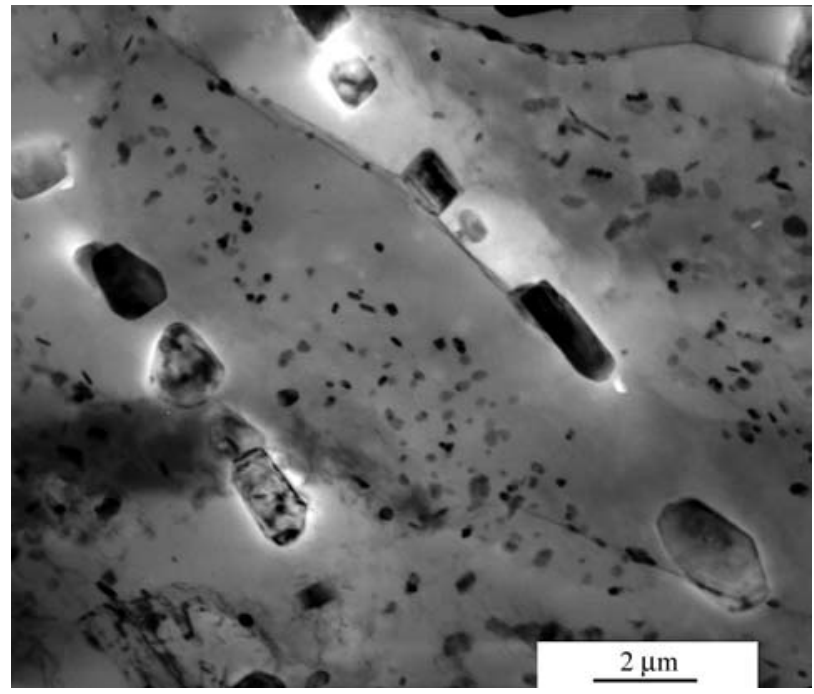

b)

Figura 99 - Microestrutura do caster após homogeneização de $500^{\circ} \mathrm{C}$ por 12 horas, microscopia eletrônica de transmissão. Amostra afinada eletroliticamente com solução contendo ácido perclórico.

Na Figura 99 nota-se que os precipitados tem um formato de bastonetes e também se percebe a presença de muitos dispersóides. Pelas análises de EDS e apresentadas nas Figuras 48 e 49, sabe-se que o precipitado que apresenta esta morfologia é a fase $\mathrm{Al}_{6} \mathrm{Mn}$. Mathew et al [1984] relata que para tratamento térmico de homogeneização acima de $645^{\circ} \mathrm{C}$ ocorre a completa transformação $6 \rightarrow \alpha$, ou seja, toda fase $\mathrm{Al}_{6} \mathrm{Mn}$ se transforma em fase $\alpha-\mathrm{Al}(\mathrm{Mn}, \mathrm{Fe}) \mathrm{Si}$. Como a homogeneização no presente estudo foi feita a $500^{\circ} \mathrm{C}$ ainda há 
presença da fase $\mathrm{Al}_{6} \mathrm{Mn}$. Estes resultados estão de acordo com os obtidos por difração de raios $\mathrm{X}$ no resíduo extraído de amostra homogeneizada na mesma condição (vide item anterior, Figura 92). Por meio da análise do difratograma do resíduo extraído foi possível identificar a presença da fase $\mathrm{Al}_{6} \mathrm{Mn}$.

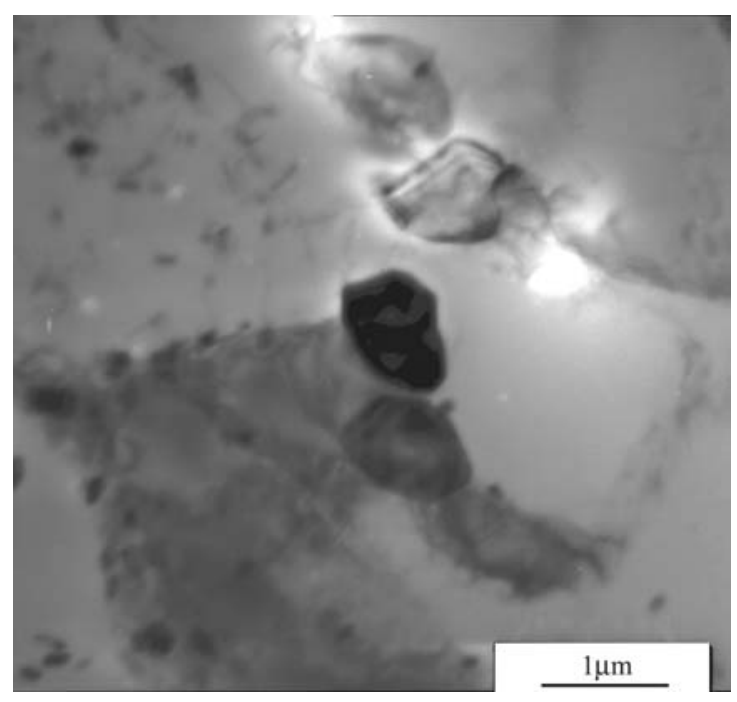

a)

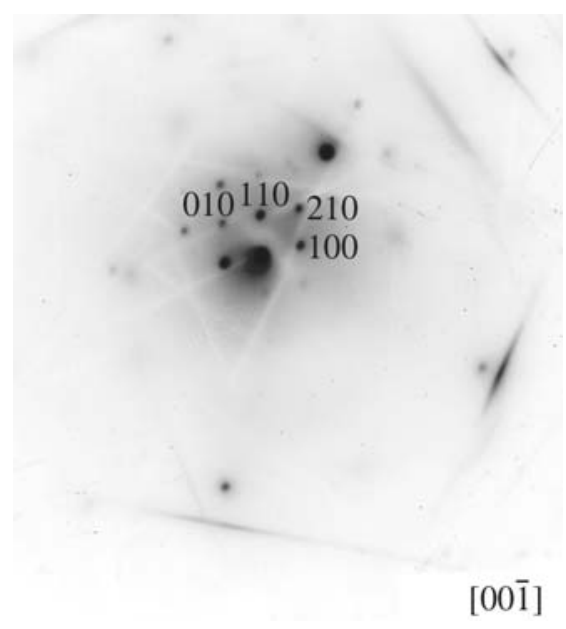

b)

Figura 100 - a) Precipitado presente na amostra caster após homogeneização de $500^{\circ} \mathrm{C} / 12 \mathrm{~h}$, microscopia eletrônica de transmissão; b) Difração de elétrons da fase $\mathrm{Al}_{6} \mathrm{Mn}$, precipitado preto mostrada em a). A direção do feixe de elétrons é indicada na micrografia. Amostra afinada eletroliticamente com solução contendo ácido perclórico.

A amostra homogeneizada a $500^{\circ} \mathrm{C}$ por $12 \mathrm{~h}$ foi atacada severamente com a solução de fenol. O objetivo do experimento foi dissolver parcialmente a matriz, deixando os precipitados expostos. Em seguida, esta amostra foi levada ao MEV onde se realizou um estudo sistemático dos precipitados com auxílio da técnica de microanálise química por dispersão de energia (EDS). A microestrutura homogeneizada a $500^{\circ} \mathrm{C}$ por 12 horas e parcialmente dissolvida em solução de fenol é mostrada na Figura 101. 


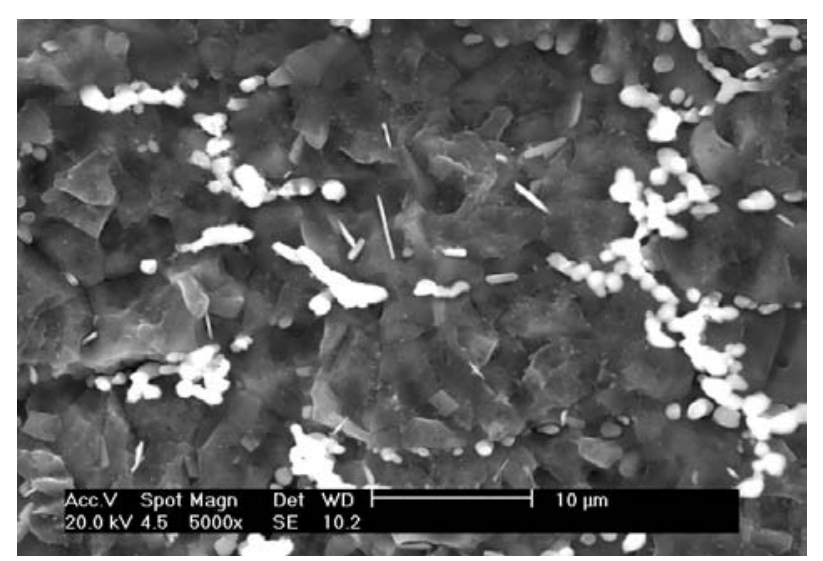

Figura 101- Amostra caster, homogeneizada a $500^{\circ} \mathrm{C} / 12 \mathrm{~h}$ e parcialmente dissolvida em fenol, microscopia eletrônica de varredura, elétrons retroespalhados.

Na Figura 101 pode-se observar a presença de colônias de precipitados com formato esférico, além de poucos precipitados em forma de bastonetes. Deve-se destacar que o fato dos precipitados estarem intactos é mais um indício de que a solução de fenol é adequada para a extração, pois dissolve apenas a matriz. Na Figura 101 nota-se a presença de precipitados em forma de agulhas. Merchant et al [1990] encontraram partículas semelhantes a estas também em amostras homogeneizadas.

Com auxílio deste ataque severo com a solução de fenol foi possível obter uma pequena quantidade de pó (Figura 102) que também foi levado ao MEV e feita análise de EDS (Tabela 12). Pelos cálculos feitos através das porcentagens atômicas encontradas, as partículas apresentam uma estequiometria próxima a $\mathrm{Al}_{12}(\mathrm{Mn}, \mathrm{Fe})_{3,2} \mathrm{Si}_{0,2}$. A estequiometria determinada neste trabalho pode ser comparada com a encontrada na literatura (Morris, 1978; Hodgson, 1981) $\mathrm{Al}_{12}(\mathrm{Mn}, \mathrm{Fe})_{3} \mathrm{Si}$. 


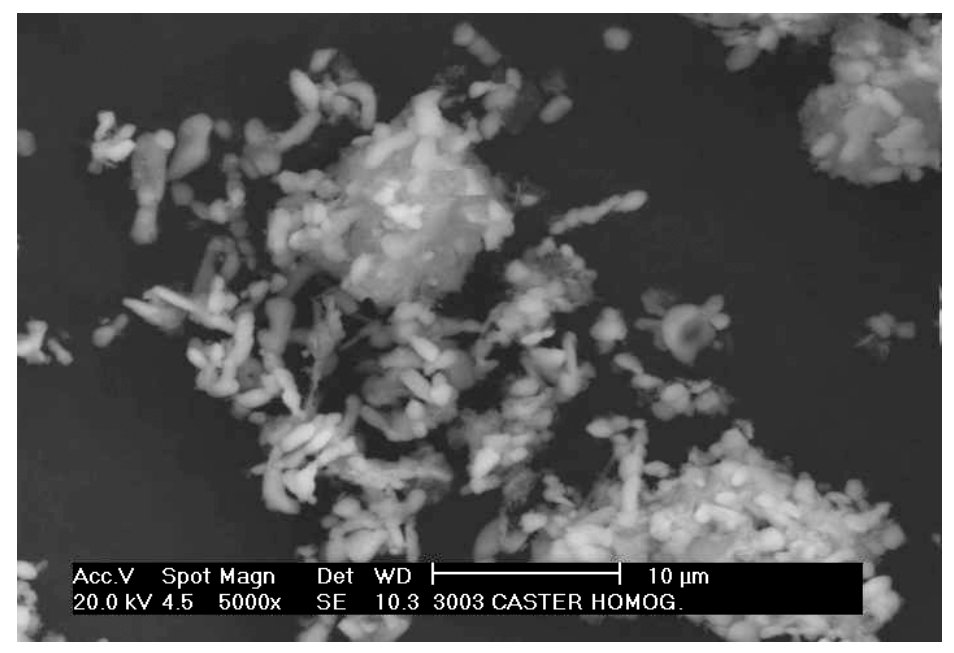

Figura 102 - Pó obtido pela dissolução química por fenol da amostra caster homogeneizada $500^{\circ} \mathrm{C} / 12 \mathrm{~h}$, microscopia eletrônica de varredura, elétrons secundários.

Tabela 12 - Análise feita por EDS do pó apresentado na Figura 102.

\begin{tabular}{|l|c|c|}
\hline Elemento & \% peso & \% atômica \\
\hline $\mathrm{Al}$ & 64 & 78 \\
\hline $\mathrm{Si}$ & 1 & 2 \\
\hline $\mathrm{Mn}$ & 23 & 13 \\
\hline $\mathrm{Fe}$ & 12 & 7 \\
\hline Total & 100.00 & 100.00 \\
\hline
\end{tabular}

\subsubsection{Evolução da transformação de fase ao longo do tempo}

A transformação da fase $\mathrm{Al}_{6} \mathrm{Mn}$ na fase $\alpha$ - $\mathrm{Al}(\mathrm{Mn}, \mathrm{Fe}) \mathrm{Si}$ foi estudada por meio de tratamentos térmicos de homogeneização na temperatura de $550^{\circ} \mathrm{C}$, em tempos variando entre 2 e 120 horas. A caracterização das amostras foi realizada com auxílio das técnicas de extração de precipitados, microscopia eletrônica de varredura, microscopia eletrônica de transmissão, medidas de condutividade elétrica, medidas de resistividade elétrica e medidas de fração volumétrica de precipitados. Os resultados da análise dos resíduos extraídos pela técnica de extração de precipitados foram apresentados no item 4.7.

A microestrutura da amostra homogeneizada a $550^{\circ} \mathrm{C} / 120 \mathrm{~h}$ é mostrada na Figura 103. Observa-se uma distribuição bem mais homogênea de precipitados, em sua maioria ora com formatos próximos a de bastonetes, ora, quadrados. Alguns precipitados maiores apresentaram aspecto facetado. 

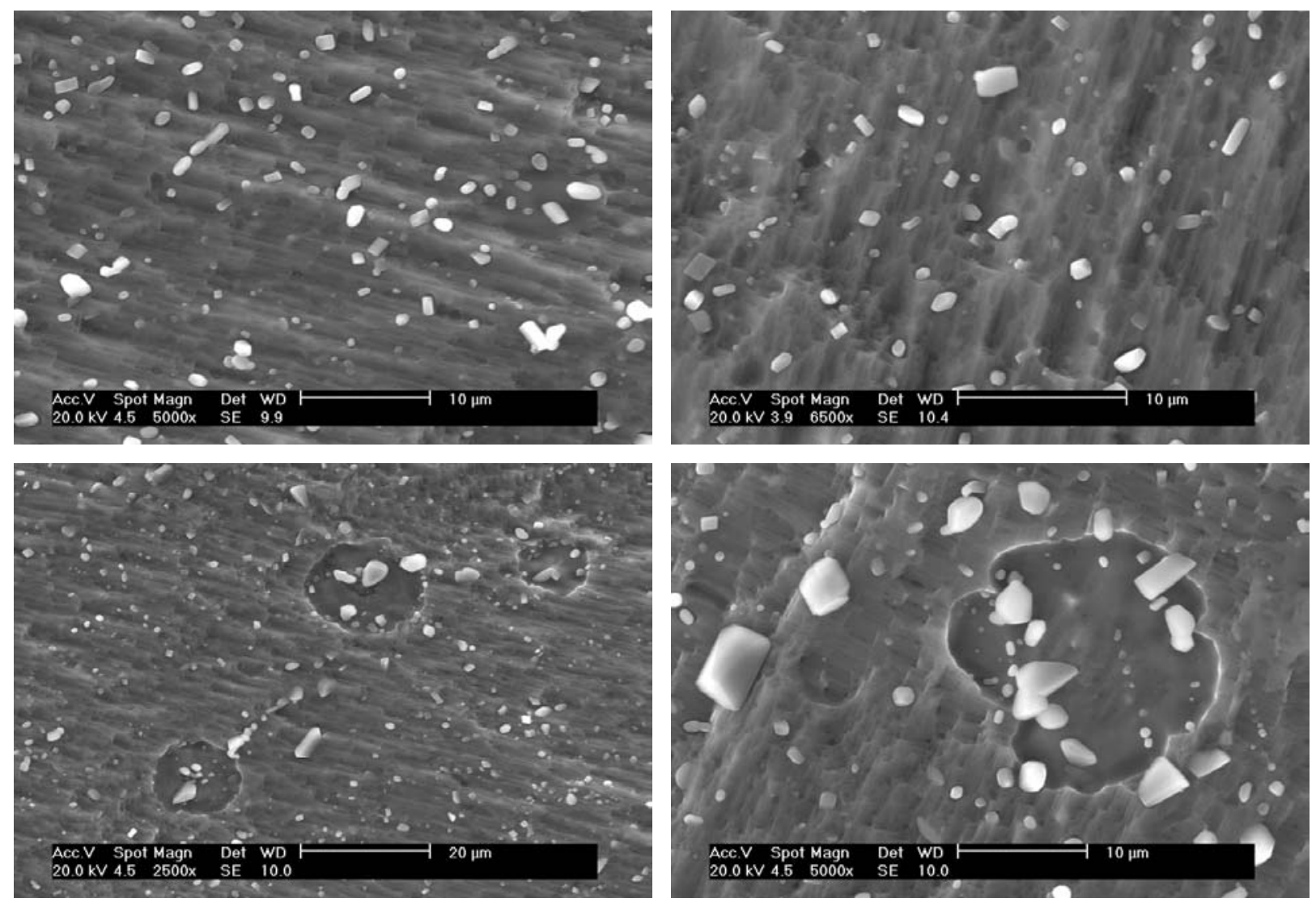

Figura 103 - Amostra caster homogeneizada a $550^{\circ} \mathrm{C}$ por $120 \mathrm{~h}$ e parcialmente dissolvida em fenol. Microscopia eletrônica de varredura, imagens de elétrons retroespalhados.

A análise por EDS dos precipitados apresentou a seguinte composição média $82,3 \% \mathrm{Al}-10,6 \% \mathrm{Mn}-6,6 \% \mathrm{Fe}-0,43 \% \mathrm{Si}$ ( $\%$ em peso), próxima à da fase $\alpha-\mathrm{Al}(\mathrm{Mn}, \mathrm{Fe}) \mathrm{Si}$. Estes resultados e a ausência de precipitados em forma de bastonete, observados na amostra homogeneizada a 500\%12horas, são fortes indícios de que a homogeneização a $550^{\circ} \mathrm{C}$ durante 120 horas é realmente suficiente para promover a completa transformação $6 \rightarrow \alpha$, tal como demonstrado pelos resultados de extração de precipitados.

Na Figura 104 é apresentada a medida de fração volumétrica de precipitados das amostras homogeneizadas a $550^{\circ} \mathrm{C}$ por diversos tempos. As imagens para análise foram feitas no microscópio eletrônico de varredura para se obter um bom contraste entre a matriz e os precipitados, uma vez que os precipitados são pequenos. A fração volumétrica foi medida com o auxílio do software KS 300. A presença na amostra de precipitados com várias classes de tamanho, alguns só observáveis por microscopia eletrônica de transmissão, dificulta a determinação da quantidade ou fração volumétrica total. A 
dificuldade é agravada pela distribuição relativamente heterogênea das partículas maiores formadas durante a solidificação. A fração volumétrica encontrada para a amostra caster bruta de fundição por este método foi de 7,6\% $\pm 0,6$, maior que 4,2\% $\pm 0,8$, encontrada pelo método descrito no item 4.1 (técnica de microscopia óptica em campo escuro). Esta diferença nos valores obtidos através de técnicas diferentes, cerca de 44,7\% maior, pode ser explicada pelo fato da microscopia eletrônica de varredura possuir maior resolução e contraste também maior entre o precipitado e a matriz. Analisando-se a Figura 104 percebese o espalhamento das medidas de fração volumétrica quando se utiliza microscopia eletrônica de varredura para esta técnica. Este resultado revela que esta técnica mostrou-se pouco apropriada no presente estudo.

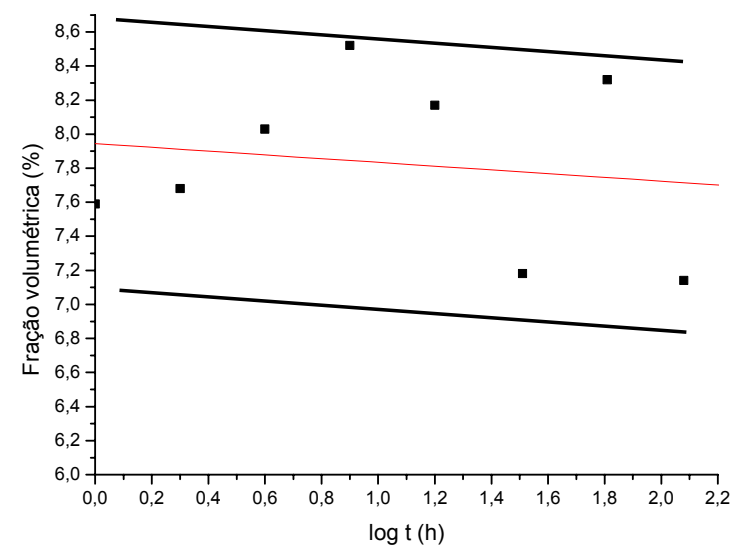

Figura 104 - Fração volumétrica dos precipitados de amostras homogeneizadas a $550^{\circ} \mathrm{C}$ por diversos tempos.

Na Figura 105 nota-se a presença de partículas em forma de agulhas na amostra homogeneizada a $550^{\circ} \mathrm{C}$ por $2 \mathrm{~h}$. Partículas com esta morfologia foram observadas na Figura 101 na amostra homogeneizada a $500^{\circ} \mathrm{C}$ por $12 \mathrm{~h}$. Partículas na forma de paralelogramos foram encontradas com bastante freqüência na amostra homogeneizada a $550^{\circ} \mathrm{C}$ por $120 \mathrm{~h}$. Na Figura 93 foi apresentado o difratograma da amostra homogeneizada a $550^{\circ} \mathrm{C}$ por $120 \mathrm{~h}$, que revelou a presença da fase $\alpha-\mathrm{Al}(\mathrm{Mn}, \mathrm{Fe}) \mathrm{Si}$, e que este tratamento térmico de homogeneização causou a transformação da fase $\mathrm{Al}_{6} \mathrm{Mn}$ em $\alpha-\mathrm{Al}(\mathrm{Mn}, \mathrm{Fe}) \mathrm{Si}$, 
também conhecida como $6 \rightarrow \alpha$. Na Figura 106 pode-se observar a presença de um precipitado que foi identificado como $\alpha-\mathrm{Al}(\mathrm{Mn}, \mathrm{Fe}) \mathrm{Si}$.

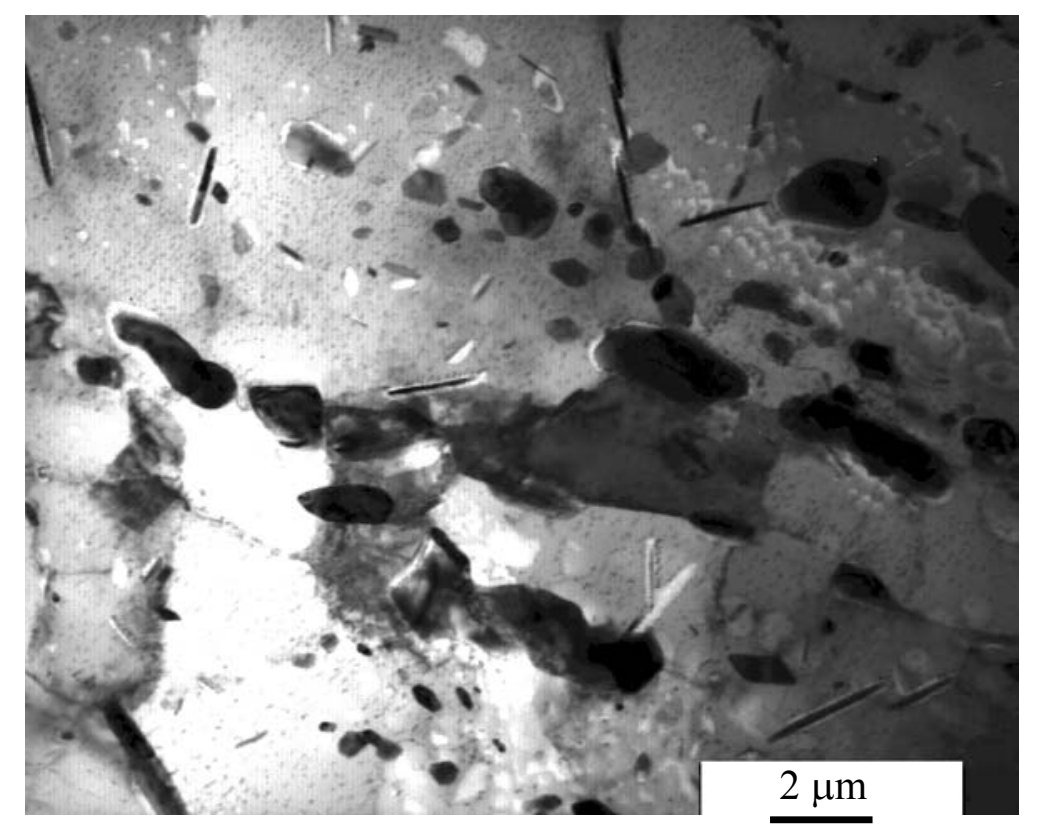

Figura 105 - Microestrutura da amostra homogeneizada a $550^{\circ} \mathrm{C}$ por $2 \mathrm{~h}$, microscopia de transmissão. Amostra afinada eletroliticamente com solução contendo ácido perclórico.

A resistividade de um monocristal puro e bem recozido é muito baixa devido à pequena quantidade de defeitos que espalham ou param os elétrons em movimento no reticulado sob a influência de uma diferença de potencial externa. Sendo a resistividade pequena então a condutividade é alta. Por outro lado, nos cristais reais existem vários tipos de imperfeições que espalham elétrons e, portanto contribuem para aumentar a resistividade (contribuindo desse modo para diminuir a condutividade). Essas contribuições são independentes entre si [Padilha, 1985]:

$\rho=\rho(\mathrm{T})+\rho(\mathrm{C})+\rho(\mathrm{L})+\rho(\mathrm{d})+\rho(\mathrm{b})$

onde, $\rho(\mathrm{T})$ resistividade devido a vibrações térmicas, $\rho(\mathrm{C})$ devido ao espalhamento causado por átomos de impureza, $\rho$ (L) devido à presença de lacunas, $\rho$ (d) devido à presença de discordâncias e $\rho$ (b) devido à presença de defeitos bidimensionais, como contornos de grão e falha de empilhamento. 

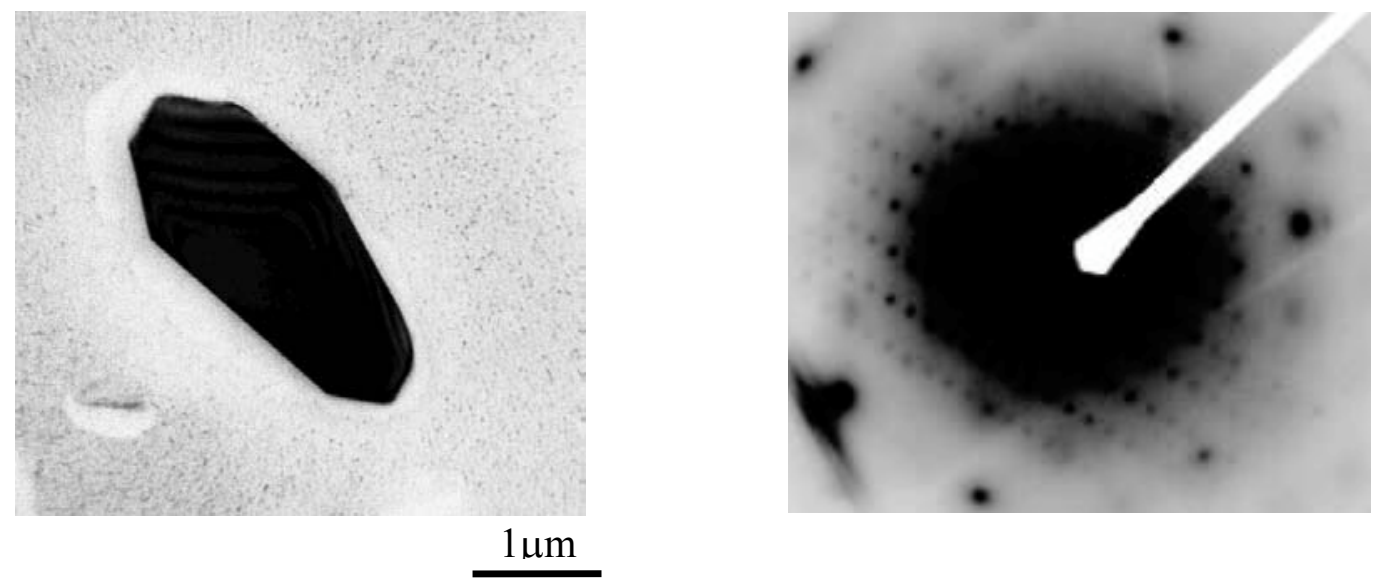

Figura 106 - a) Precipitado da amostra homogeneizada a $550^{\circ} \mathrm{C} / 120 \mathrm{~h}$; b) difração de elétrons do precipitado indexada como fase $\alpha$ feixe na direção [0 010 ] plano mais próximo é da família $\left\{\begin{array}{lll}0 & 2 & 2\end{array}\right\}$ e o segundo mais próximo é $\left\{\begin{array}{lll}2 & 2 & 2\end{array}\right\}$. Amostra afinada eletroliticamente com solução contendo ácido perclórico.

Medidas de resistividade são de extrema valia no estudo de defeitos puntiformes, tais como, lacunas, intersticiais e átomos de soluto. Esses defeitos em virtude de suas pequenas dimensões e baixas energias de formação, são dificilmente estudados por técnicas diretas.

A Figura 107 mostra a evolução da razão entre a resistividade elétrica à $300 \mathrm{~K}$ e à $77 \mathrm{~K}$, da liga 3003, durante tratamento térmico. Quando a liga foi aquecida a $550^{\circ} \mathrm{C}$ houve um aumento desta razão, mostrando que a quantidade de Mn em solução sólida está menor após tratamento térmico. Com o aquecimento a condutividade aumenta, pois o teor de $\mathrm{Mn}$ em solução sólida diminui. Houve uma variação na condutividade ao longo do tempo. Estudos [Li, 2003 b] indicam que a $300^{\circ} \mathrm{C}$ aumenta rapidamente e atinge um máximo a $530^{\circ} \mathrm{C}$ e então decresce com o aumento da temperatura. Isto indica que $\mathrm{Mn}$ na solução sólida supersaturada começa a precipitar a $300^{\circ} \mathrm{C}$ e quando é aquecida a $530^{\circ} \mathrm{C}$ algumas partículas começam a se dissolver (por isso cai a condutividade) devido ao aumento da solubilidade de Mn em solução sólida com o aumento da temperatura. A condutividade volta a aumentar a $600^{\circ}$, mas vagarosamente. Mostra que Mn, mantendo-se a amostra a $600^{\circ} \mathrm{C}$, precipita continuamente na matriz [Li, $\left.2003 \mathrm{~b}\right]$. 


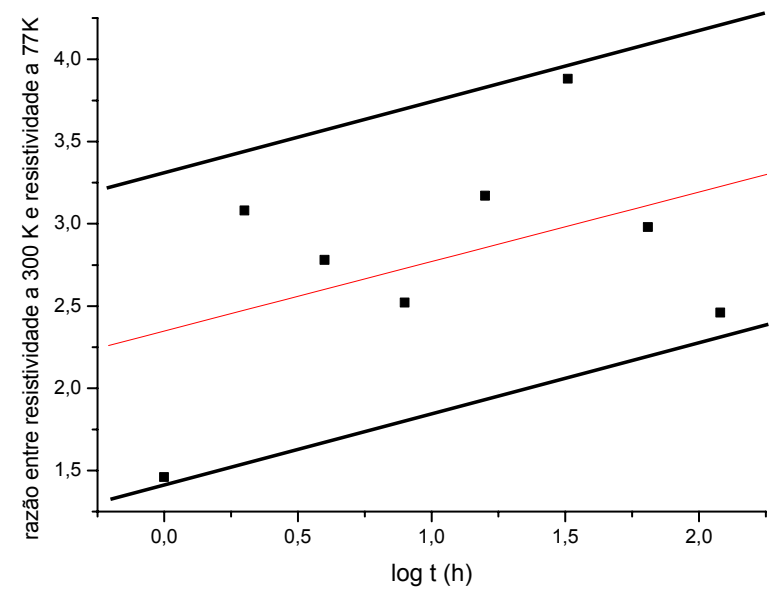

Figura 107 - Evolução da resistividade elétrica da liga 3003 durante tratamento térmico a $550^{\circ} \mathrm{C}$. 


\section{Conclusões}

Para tornar a leitura e o entendimento mais fáceis optou-se por organizar as conclusões por assuntos, assim como eles foram apresentados e discutidos no capítulo anterior.

Caracterização microestrutural inicial das amostras provenientes dos processos “caster" e laminada a quente

Com o auxílio de microscopia eletrônica de transmissão e de microdureza concluise que durante o processamento "roll caster" há considerável deformação plástica, com a formação de subgrãos e células de discordâncias.

Comparando-se a dureza das amostras provenientes de fundição contínua de chapas ("roll caster") e de lingotamento semicontínuo seguido de homogeneização e laminação a quente, conclui-se que a diferença de dureza está associada a três mecanismos: endurecimento por deformação, endurecimento por refino de grão e endurecimento por dispersão de precipitados incoerentes. Sendo que o mecanismo de endurecimento por deformação é o que mais influencia na dureza da amostra caster.

A microestrutura, a morfologia e o tamanho de grão, da amostra "roll caster" bruta de fundição são mais homogêneos que na amostra laminada a quente. $O$ tamanho de grão da amostra laminada a quente é muito maior e a morfologia dos grãos, ao longo da espessura e nas seções longitudinal e transversal, é mais heterogênea.

Por meio de medidas de condutividade elétrica, foi possível demonstrar que na amostra "roll caster" bruta de fundição há uma supersaturação de elementos de liga, especialmente manganês, em solução sólida quando comparada com a laminada a quente.

A composição química não varia ao longo da espessura das chapas provenientes dos dois processos. Por meio da técnica de microscopia óptica em campo escuro, seguida de análise de imagens foi possível determinar a fração volumétrica de precipitados de forma mais rápida e eficiente. A fração volumétrica de precipitados ao longo da espessura da amostra caster é maior na região central, devido ao resfriamento mais lento no centro da chapa. 
Análise comparativa de textura resultante dos processos "caster" e laminada a quente

Para amostras que apresentam intensidade de textura relativamente alta, a imposição da simetria triclínica ou ortorrômbica não acarreta em diferenças significativas. Com a imposição da simetria ortorrômbica ocorreu um alargamento nos picos das principais orientações para FDO.

As chapas, laminada a quente e caster, exibem forte gradiente de textura ao longo da espessura. A textura predominante nos dois processos, ao longo da espessura, é a do tipo latão $\{011\}<211>$. Outra componente importante é a cubo rodado $\{001\}<110>$ que predominou na superfície. A principal diferença de textura ao longo da espessura, entre as chapas provenientes dos dois processos distintos, foi encontrada na região $1 / 2$ de espessura. Enquanto na amostra caster foram encontradas as componentes do tipo S, a tipo cobre e latão, na amostra laminada a quente apenas aparece a componente cubo rodado.

\section{Microestrutura e textura de laminação a frio de chapas provenientes do processo “caster"}

A componente cubo rodado $\{001\}<110>$ encontrada na superfície da amostra caster não foi encontrada após laminação a frio.

A textura de laminação a frio de chapas provenientes do processo "caster" é uma textura de laminação a frio típica do alumínio, composta pelas componentes: latão $\{011\}<211>$, $S\{123\}<634>$ e cobre $\{112\}<111>$ ao longo da fibra $\beta$.

Após $67 \%$ de redução na laminação a frio não houve alteração na textura.

Microestrutura, textura e microtextura de recristalização de chapas provenientes do processo "caster"

Após a alta redução de $91 \%$ e o posterior tratamento térmico de $400^{\circ} \mathrm{C} / 1 \mathrm{~h}$, que a chapa proveniente do processo caster sofreu, foi possível obter uma textura de recristalização com uma combinação da textura tipo cubo (recristalização) somada à 
parcela de textura de deformação, que no caso do alumínio e suas ligas, sabe-se que propiciam melhores resultados de estampabilidade. Enquanto para uma redução menor (de $67 \%$ ) a componente cubo somada a componente cubo ${ }_{N D}$ prevaleceram após recristalização.

Estudo do efeito do tratamento térmico prévio de homogeneização no encruamento e na posterior recristalização de chapas provenientes do processo "caster"

Com o tratamento térmico de homogeneização da amostra caster (bruta de fundição) a $550^{\circ} \mathrm{C}$ por 24 horas houve acentuado crescimento de grão.

Ao longo da espessura da amostra caster bruta de fundição há uma fração relativamente alta de contornos do tipo $\Sigma 1$, ou seja, há fração alta de subcontornos.

Durante a laminação a frio, a chapa que sofreu tratamento térmico antes da laminação e a chapa que foi laminada no estado bruto de fundição tiveram comportamento similar em relação à redução em área versus dureza. No entanto, a chapa que sofreu tratamento térmico antes da laminação apresentou valores de dureza menores, pois continha densidade de discordância menor e menor quantidade de Mn em solução sólida, embora tenha ocorrido precipitação durante homogeneização.

A variação da dureza em função da temperatura da chapa que sofreu tratamento térmico antes da laminação e da chapa que foi laminada no estado bruto de fundição revela que a recristalização foi retardada na amostra, inicialmente, bruta de fundição. Pois, a precipitação ocorreu simultaneamente com a recristalização, com isso os dispersóides precipitaram preferencialmente na microestrutura deformada, em subcontornos ou nas discordâncias isoladas, levando a um considerável atraso no rearranjo das discordâncias e na nucleação da recristalização.

A comparação microestrutural após recristalização entre a chapa que sofreu tratamento térmico antes da laminação e a chapa que foi laminada no estado bruto de fundição mostra nitidamente que o tratamento térmico de homogeneização, além de acelerar a posterior recristalização estática, causa apreciável refino de grão.

A textura de recristalização difere entre a chapa que sofreu tratamento térmico antes da laminação e a chapa que foi laminada no estado bruto de fundição. Observa-se a predominância da componente cubo, textura típica de recristalização para o primeiro caso e 
a presença da componente $\{113\}<\overline{1} 10>$, pertencente à fibra DL, no segundo caso.

\section{Comparação entre as técnicas de EBSD e de difração de raios $X$}

Com 50500 números de medidas de orientações utilizando EBSD já foi possível caracterizar a textura do material, quando comparado com resultado de textura proveniente de difração de raios X.

\section{Técnicas de extração de precipitados}

Por meio da análise dos difratogramas dos resíduos provenientes das extrações conclui-se que a extração de precipitados pelos métodos apresentados facilitou a identificação das fases presentes na liga bruta de fundição e na liga homogeneizada.

Por meio da técnica de extração de precipitados e análise destes por difração de raios $\mathrm{X}$ foi possível avaliar, que nas amostras caster bruta de fundição as partículas identificadas são a fase $\mathrm{Al}_{6}(\mathrm{Mn}, \mathrm{Fe})$ e $\alpha$-AlMnSi.

O método de extração que apresentou melhores resultados foi dissolução química com fenol.

\section{Estudo da transformação do precipitado Al $_{6}$ Mn durante tratamentos de homogeneização}

Após o tratamento térmico de homogeneização da amostra caster (bruta de fundição) a $500^{\circ} \mathrm{C}$ por 12 horas não ocorre a completa transformação $6 \rightarrow \alpha$, ainda há presença da fase $\mathrm{Al}_{6} \mathrm{Mn}$. Mas após o tratamento térmico de homogeneização da amostra caster (bruta de fundição) a $500^{\circ} \mathrm{C}$ por 120 horas ocorre a completa transformação $6 \rightarrow \alpha$.

$\mathrm{O}$ tratamento térmico de homogeneização de $500^{\circ} \mathrm{C}$ por 12 horas permitiu uma distribuição mais homogênea dos precipitados. Os precipitados se tornaram mais esferoidizados, quando comparado com a amostra bruta de fundição. Houve aumento de fração volumétrica de precipitados.

A fase $\alpha$ apresenta uma estequiometria próxima a $\mathrm{Al}_{12}(\mathrm{Mn}, \mathrm{Fe})_{3,2} \mathrm{Si}_{0,2}$. 
A evolução da transformação de fase ao longo do tempo revelou que para 120 horas há uma distribuição bem mais homogênea de precipitados, com morfologia facetada e de bastonetes.

Quando a liga foi aquecida a $550^{\circ} \mathrm{C}$ houve um aumento da razão entre a resistividade elétrica à $300 \mathrm{~K}$ e à $77 \mathrm{~K}$, mostrando que a quantidade de $\mathrm{Mn}$ em solução sólida está menor após tratamento térmico. Com o tratamento térmico a condutividade aumenta, pois Mn em solução sólida diminui. 


\section{Referências Bibliográficas}

ALEXANDER D. T. L.; HAMERTON R. G.; CAMA H.; GREER A. L. Study of intermetallic phase transformation in $3 \mathrm{XXX}$ alloys using diffusion couples, Materials Science Forum, vol.396-402, pp.681-686, 2002.

ANTONIONE C., DELlA GATTA G., RIONTINO G. and VENTURELLO G. Graingrowth and secondary recrystallization in iron, Jornal of Materials Science, vol. 8, pp. 1$10,1973$.

ANTONIONE C., MARINO F., RIONTINO G. and TABASSO M. C. Effect of slight deformations on grain-growth in iron, Journal of Materials Science, vol. 12, pp. 747-750, 1977.

ASHBY, M. F. Work hardening in dispersion hardened crystals. Philosophical Magazine, vol. 14, pp. 1157-1178, 1966.

ASHBY, M. F. The deformation of plastically non-homogeneous alloys. In:_Strengthening Methods in Crystals. A. KELLY e R. B. NICHOLSON (Editores), London, Applied Science Publish, capítulo 3, pp. 137-192, 1971.

BECK P. A.; SPERRY, P. R. Strain induced grain boundary in high purity aluminum. Journal of applied physics, vol. 21, pp. 150-152, 1950.

BECK P. A.; SPERRY, P. R., HU H., The orientation dependence of the rate of boundary migration. Journal of applied physics, vol. 21, pp. 420-425, 1950.

BENUM S., NES E. Effect of precipitation on the evolution of cube recrystallisation texture. Acta Materialia, vol.45, n 11, pp. 4593-4602, 1997. 
BERG B. S., HANSEN V., ZAGIERSKI P. T., NEDREBERG M. L., OLSEN A., GJONNES J., Gauge reduction in twin roll casting of an AA5052 aluminum alloy: The effects on microstructure, Journal of Materials Processing Technology, vol.53, pp.65-74, 1995.

BEVER M. B.; HOLT D. L.; TITCHENER A. L. The stored energy of cold work. Progress in Materials Science, vol. 17, pp. 1-190, 1973.

BLUM W., SCHLÖGL C., MEIER M., Subgrain formation and subgrain boundary migration in $\mathrm{Al}-5 \mathrm{Mg}$ during high temperature deformation in the range of class $\mathrm{A}$ behaviour in comparison with pure aluminium, Zeitschrift für Metallkunde, pp. 631-637, vol. $86, \mathrm{n}^{\circ} 9,1995$.

BLUM, W.; MCQUEEN, H. J. Dynamics of recovery and recrystallization. Materials Science Forum, vol. 217-222, pp. 31-42, 1996.

BORBÉLY, A.; DRIVER, J.H. Stored energies in plastically deformed metals. In: Recrystallization and grain growth. Proceedings of the First Joint International Conference. G. Gottstein e D. A. Molodov (Editores), Editora Springer-Verlag, Aachen, vol.2, pp. 635-644, 2001.

BRANDES E. A., Smithells Metals Reference Book, $6^{\circ}$ Edição. London: Butterworths, 1983.

BUNGE H. J. Texture analysis in materials science mathematical methods. 1ed. Butterworths, 1982.

BURGERS W. G., LOUWERSE P. C., Über den Zusammenhang zwischen deformationsvorgang und rekristallisationnstextur bei aluminium, Zeitschrift für Physik, vol.67, pp. 605-678, 1931. 
CAHN R. W. The use of metallic single crystals in metals research: a concise history, Zeitschrift für Metallkunde, vol. 90, pp. 860-862, 1999.

CHEONG S. W., HILINSKI E. J. AND ROLLETT A. D. Grain growth in a low-loss coldrolled motor-lamination steel, Metallurgical and Materials Transactions A, vol. 34A, pp. 1321-1327, 2003.

CHO Y. K., ION D. Y. AND HENRY M. The effects of deformation and pre-heattreatment on abnormal grain growth in RENÉ 88 superalloy, Metallurgical and Materials Transactions A, vol. 32A, pp. 3077-3090, 2001.

COGAN S. F., GAYLE F. W., KLEIN J. D., COCKS F. H., SHEPARD M. L. Extraction and X-ray analysis of phases in aluminium alloys. Journal of Materials Science, vol.13, pp. 2687-2691, 1978.

COOK R., GROCOCK P. G., THOMAS P. M., EDMONDS D. V., HUNT J. D., Development of the twin roll casting process, Journal of Materials Processing Technology, vol.55, pp.76-84, 1995.

CULLITY, B.D.; STOCK, S.R. Elements of X-Ray diffraction. 3 ed. New Jersey: Prentice Hall, 2001. pp.664.

DAALAND O.; NES E. Recrystallization texture developmente in commercial Al-Mn-Mg alloys. Acta Materialia. vol. 44, pp. 1413-1435, 1996.

DAALAND O.; NES E. Origin of cube texture during hot rolling of commercial Al-MnMg alloys. Acta Materialia. vol. 44, pp. 1389-1411, 1996.

DAVIS J. R. Microstructures of aluminum alloys. In: Aluminum and aluminum alloys, ASM specialty handbook. Ohio: ASM International, 1993, pp.784. 
DINGLEY, D. J.; FIELD, D. P. Electron backscattered diffraction and orientation imaging microscopy, Materials Science and Technology, vol.13, pp. 69-73, 1997.

DOHERTY R. D. Nucleation and growth kinetics of different recrystallization texture components, Scripta Metallurgica, vol. 19, pp. 927-930, 1985.

DOHERTY R. D. Recrystallization and texture, Progress in Materials Science, vol. 42, pp. 39-58, 1997.

DOHERTY, R. D.; HUGHES, D. A.; HUMPHREYS, F. J.; JONAS, J. J.; JUUL JENSEN, D.; KASSNER, M. E.; KING, W. E.; MCNELLEY, T. R.; MCQUEEN, H. J.; ROLLETT, A. D. Current issues in recrystallization: a review, Materials Science and Engineering, vol. A238, pp. 219-274, 1997.

DOHERTY R. D.; CHEN L. C.; SAMAJDAR I. Cube recrystallization texture experimental results and modeling, Materials Science Engineering A, vol. A257, pp. 18-36, 1998.

EDINGTON J.W. Practical electron microscopy in materials science, New York: Van Nostrand Reinhold Company, 1976, 344p.

ENGLER, O. Nucleation and growth during recrystallization of aluminium alloys investigated by local texture analysis. Materials Science and Technoloy, vol. 12, pp. 859872, 1996.

FALLEIROS I. G. S. Transformações estruturais durante homogeneização de Al comercialmente puro. 1970. 86p. Tese (Doutorado) - Escola Politécnica, Universidade de São Paulo, São Paulo, 1970.

FURRER P. Gefügeänderungen bei der Wärmebehandlung Von Al-Mn-Stranggußbarren, Zeitschrift für Metallkunde, vol.70, pp. 699-706, 1979. 
GODEC, M.; JENKO, M. Presentation methods of textures measurements, Materiali in Tehnoloije, vol.34, pp. 359-364, 2000.

GONÇALVES, M. Processamento termomecânico e evolução microestrutural de ligas de alumínio: aspectos da metalurgia física fundamental. In: Textura e relações de orientação. A.P. Tschiptschin e outros (Editores), EPUSP, São Paulo, $2^{\circ}$ edição, pp. 330-348, 2003.

GUPTA A. K., MAROIS P. H. and LLOYD D. J. Review of techniques for the extraction of second-phase particles from aluminum alloys. Materials Characterization, vol.37, pp. $61-80,1996$.

HAESSNER F. Recrystallization of metallic materials. Stuttgart: Riederer-Verlag, $2^{\circ}$ edição, 1978. 293p.

HAGA T., SUZUKI S., Study on high speed twin roll caster for aluminum alloys, Journal of Materials Processing Technology, vol.143-144, pp.895-900, 2003.

HAGA T., TKAHASHI K., IKAWAAND M., WATARI H., Twin roll casting of aluminum alloy strips, Journal of Materials Processing Technology, vol.153-154, pp.42-47, 2004.

HANSEN V.; ANDERSSON B.; TIBBALLS J. E.; GJONNES J. Metallurgical reactions in two industrially strip-cast aluminium-manganese alloys, Metallurgical and Materials Transactions B, vol. 26B, pp. 839-849, 1995.

HAUSCH G.; FURRER P.; WARLIMONT H. Recrystallization and precipitation in AlMn-Si alloys. Zeitschrift für Metallkunde, vol. 69, pp. 174-180, 1978.

HIRSCH J.; NES E.; LÜCKE K. Rolling and recrystallization textures in directionally solidified aluminum, Acta Metallurgica, vol. 35, pp. 427-438, 1987. 
HJELEN J.; ORSUND R.; NES E. On the origin of recrystallization textures in aluminum, Acta Metallurgica e Materialia, vol. 39, pp. 1377-1404, 1991.

HODGSON P., PARKER B. A. The composition of insoluble intermetallic phases in aluminium alloy 6010. Journal of Materials Science, vol.16, pp. 1343-1348, 1981.

HORNBOGEN, E. and KÖSTER, U. Recrystallization of two-phase alloys. In HAESSNER F. Recrystallization of metallic materials. Stuttgart: Riederer-Verlag, $2^{\circ}$ edição,1978, 293p.

HUMPHREYS, F.J.; HATHERLY, M. Recrystallization and related annealing phenomena. Oxford: Pergamon, 1995. 497p.

HUMPHREYS, F. J. Quantitative metallography by electron backscattered diffraction. Journal of Microscopy, vol.195, pp. 170-185, 1999.

HWANG N. M., LEE B. J., HAN C. H., Texture evolution by grain growth under a system of anisotropic grain baoundary energy. Scripta Materialia, vol. 37, pp. 1761-1767, 1997.

INAGAKI, H. Basic earing behavior of fcc and bec metals in cup drawing, Zeitschrift für Metallkunde, vol.82, pp. 361-372, 1991.

KOCKS U.F.; TOMÉ C.N.; WENK H.R. Texture and anisotropy: preferred orientations in polycrystals and their effect on materials properties. Cambridge : Cambridge University Press, 1998. pp.676.

KOLOSOSKI J.; FILHO F. A.; COUTO A. A. Curso de metalografia do alumínio e suas ligas. São Paulo: ABAL. 1998. pp. 148.

KOO J. B., YOON D. Y. AND HENRY M. F. The effect of small deformation on abnormal grain growth in bulk $\mathrm{Cu}$. Metallurgical and Materials Transactions A, vol. 33A, pp. 3803-3815, 2002. 
KOSTER U. Recrystallization involving a second phase, Metal Science, vol.8, pp. 151-160, 1974.

KRONBERG M. L., WILSON F. H., Secondary recrystallization in copper. Transactions AIME, vol. 185, pp. 501-514, 1949.

LIANG X, Edge containment of a twin roll caster for near-net-shape strip casting, Journal of Materials Processing Technology, vol.63, pp. 788, 1997.

LI B. Q., Producing thin strips by twin roll casting, Part II: Process modeling and development, Journal of the Minerals Metals and Materials Society, vol. 47, pp. 13-17, 1995.

LEE C. S.; DUGGAN B. J.; SMALLMAN R. E. A theory of deformation banding in cold rolling. Acta Metallurgica et Materialia, vol. 41, pp. 2265-2270, 1993.

LI Y. J.; ARNBERG L. Precipitation of dispersoids in DC-cast 3003 alloy, Materials Science Forum, vol.396-402, pp. 875-880, 2002.

LI Y. J.; ARNBERG L. Evolution of eutectic intermetallic particles in DC-cast AA3003 alloy during heating and homogenization, Materials Science and Engineering, vol. A347, pp.130-135, 2003 a.

LI Y. J.; ARNBERG L. Quantitative study on the precipitation behavior of dispersoids in DC-cast AA3003 alloy during heating and homogenization. Acta Materialia. vol.52, pp. 3415-3428, 2003 b. 
LI Z. J.; LIU Q. Microstructure and local crystallography of rolled Al - $1 \mathrm{wt} \% \mathrm{Mn}$ single crystal of $\{001\}<110>$ orientation. Materials Science and Engineering A, vol.338, pp.237242, 2002.

LIMA N. B., LIMA L. M. F. G. E PADILHA A. F. Texturas de recristalização. In: Textura e relações de orientação. A. P. TSCHIPTSCHIN e outros (Editores), EPUSP, São Paulo, pp. 59-75. (ISBN 85-86686-16-6), 2001.

LIMA L. M. F. G. Estudo da evolução da textura, da microtextura e da mesotextura de recristalização, após baixos graus de deformação a frio, em dois aços ferríticos com baixo teor de carbono. 2005. 114p. Tese (Doutorado) - Instituto de Pesquisas Energéticas e Nucleares, São Paulo, 2005.

LOCKYER S. A., YUN M., HUNT J. D., EDMONDS D. V., Micro and Macrodefects in thin sheet twin roll cast aluminum alloys, Materials Characterization, vol.37, pp. 301-310, 1996.

LOW M. Determinação do estágio inicial da recristalização em ligas de alumínio por difração de raios-X. 2000. 113p. Dissertação (Mestrado) - Instituto de Pesquisas Energéticas e Nucleares. São Paulo. 2000.

MACHADO R. C. Um século do processo Hall/Heroult de produção de alumínio. Metalurgia, vol.42, 1986, 295p.

MARTIN, J. W.; DOHERTY, R. D.; CANTOR, B. Stability of microstructure in metallic systems, Cambridge: Cambridge University Press, $2^{\circ}$ edição, 1997. 426p.

MARTINS, J. P. Estudo da recuperação e recristalização do tântalo com microestrutura oligocristalina laminado a frio. 2002. 112p. Dissertação (Mestrado) - Faculdade de Engenharia Química de Lorena. Lorena. 2002. 
MATHEW E. V.; RAMACHANDRAN T. R.; GUPTA K. P.; DAS S. Homogenization of commercial Al-Mn alloys, Journal of Materials Science Letters, vol. 3, pp. 605-610, 1984.

MAURICE, C.I.; DRIVER, J.H. Hot rolling textures of FCC metals - part I experimental results on Al single and polycristals. Acta Materialia. vol.45, pp. 4627-4638, 1997.

MCQUEEN, H. J.; EVANGELISTA, E.; KASSNER, M. E. The classification and determination of restoration mechanisms in the hot working of Al alloys, Zeitschrift für Metallkunde, vol.82, pp. 336-343, 1991.

MERCHANT, H. D., MORRIS, J. G., HODGSON, D. S. Characterization of intermetallics in aluminum alloy 3004. Materials Characterization, vol. 25, pp. 339-373, 1990.

MIYAZAWA K., SZEKELY A. Mathematical model of the splat cooling process using the twin roll technique, Metallurgical Transactions A, vol. 12A, pp.1047, 1981.

MONDOLFO L. F. 'Manganese in aluminium alloys', Norwich: Edited by The Manganese Centre, 1977, 118p.

MONDOLFO L. F. Aluminum alloys: structure and properties, London: Butterworths. 1976, 971p.

MORRIS, P. L., DUGGAN, B. J. Precipitation and recrystallization in Al-1,8\% Mn alloy. Metal Science, Janeiro, pp. 1-7, 1978.

MURAKAMI K., TARASIUK J., REGLÉ H. AND BACROIX B. Study of the texture formation during strain induced boundary migration in electrical steel sheets, Materials Science Forum, vols. 467-470, pp. 893-898, 2004.

PADILHA A. F. Utilização da extração de precipitados na identificação de constituintes microestruturais. Anais do XXXVIII Congresso Anual da ABM, vol.3, pp. 299-318, 1983. 
PADILHA A. F., AMBROZIO F. F. Técnicas de análise microestrutural, São Paulo: Ed. Hemus, 1985, 190p.

PADILHA, A. F.; SICILIANO Jr., F. Encruamento, recristalização, crescimento de grão e textura. São Paulo: ABM, 1996. $2^{\circ}$ edição. $158 \mathrm{p}$.

PADILHA, A.F.; PLAUT R. L. Work hardening, recovery, recrystallization and grain growth. In TOTTEN G. E. and MACKENZIE D. S. Handbook of aluminum, Alloy production and materials manufacturing. New York: Marcel Dekker, 2003. 724p.

PADILHA A. F., SICILIANO Jr. F. Crescimento de regiões recristalizadas. In: Textura e relações de orientação. A. P. TSCHIPTSCHIN e outros (Editores), EPUSP, São Paulo, $2^{\circ}$ edição, pp. 72-84. (ISBN 85-86686-16-6), 2003a.

PETTERSEN T.; FURU T.; HÅKONSEN A. Effect of changing homogenization treatment for the alloys AA3102 and AA3103, Materials Science Forum, vol.396-402, pp.1067-1072, 2002.

PIMENTA Jr., F. C. Interação entre precipitação e recristalização em uma liga de alumínio da série 3000. 1985. 92p. Dissertação (Mestrado) - Faculdade de Engenharia de Campinas, Universidade Estadual de Campinas, Campinas, 1985.

PIMENTA F. C. Jr.; MONTEIRO W. A., PADILHA A. F. A microestrutura de chapas laminadas a quente da liga de alumínio 3003. Revista Latinoamericana de Metalurgia y Materiales, vol.6, pp. $19-23,1986$.

PIMENTA F. C. Jr; ARRUDA A. C. F.; PADILHA A. F. Resistance to recrystallization in Al-1\%Mn alloys. Zeitschrift für Metallkunde, vol. 77, pp. 522-528, 1986. 
POLMEAR J. 'Light Alloys - Metallurgy of the light metals, New York: Edward Arnold, $2^{\circ}$ edição, 1989, 278p.

POSPIECH, J.; JURA J.; GOTTSTEIN G. Statistical analysis of single grain orientation data generated from model textures, Materials Science Fórum, vol. 157-162, pp. 407-412, 1994.

PULGARÍN, C. I. H. Microestrutura e textura de fitas ("tapes") de aço inoxidável dúplex produzidas por solidificação ultra-rápida ("melt-spinning"). 2003. 92p. Dissertação (Mestrado) - Escola Politécnica, Universidade de São Paulo. São Paulo, 2003.

RAABE, D.; LÜCKE, K. Rolling and annealing textures of BCC metals, Materials Science Forum, vol.157-162, pp. 597-610, 1994.

RANDLE V. and BROWN A. The effects of strain on grain misorientation texture during the grain growth incubation period, Philosophical Magazine A, vol. 58, pp. 717-736, 1988.

RANDLE V. Microtexture determination and its applications. London: The Institute of Materials, 1992, 174p.

RANDLE V. Microtexture investigation of the relationship between strain and anomalous grain growth, Philosophical Magazine A, vol. 67, pp. 1301-1313, 1993a.

RANDLE V. Strain-induced secondary recrystallization. In: M. Fuentes and J. Gil Sevillano (eds.) Recrystallization '92, Trans Tech Publications, pp. 189-194, Aedermannsdorf, Switzerland, 1993 b.

RANDLE, V.; ENGLER, O. Introduction to texture analysis. Macrotexture, microtexture and orientation mapping. Singapore, Gordon and Breach Science Publishers, 2000, 388p. 
RIONTINO G., ANTONIONE C., BATTEZZATI L., MARINO F. AND TABASSO M. C. Kinetics of abnormal grain growth in pure iron, Jornal of Materials Science, vol. 14, pp. 86-90, 1979.

SAITOH T., HOJO H., YAGUCHI H., KANG C. G., Two dimensional model for twin roll continuous casting, Metallurgical Transactions B, vol. 20B, pp.381, 1989.

SANDERS R. E. Jr. Technology innovation in aluminium products. JOM, vol. 53, pp. 21$25,2001$.

SAMAJDAR I; DOHERTY R. D. Grain boundary misorientation in DC-cast aluminium alloy. Scripta Metallurgica et Materialia, vol. 31, pp.527-530, 1994.

SANDIM, H. R. Z., MARTINS, J. P., PADILHA, A. F., Orientation effects during grain subdivision and subsequent annealing in coarse-grained tantalum, Scripta Materialia, vol.45, pp.733-738, 2001.

SANDIM, H. R. Z., MARTINS, J. P., PINTO, A. L., PADILHA, A. F. In-grain and grainto-grain textural inhomogeneities in coarse-grained tantalum. Materials Science Forum. Suiça, vol.467-70, Part 1, pp.507 - 512, 2004.

SANTOS C. A., SPIM J. A. JR., GARCIA A, Modeling of solidification in twin roll strip casting, Journal of Materials Processing Technology, vol.102, pp.33-39, 2000.

SAXENA A., SAHAI Y., Modeling of fluid flow and heat transfer in twin roll caster of aluminum alloys, Materials Transactions, pp. 206-213, vol.43, 2002.

SERNA M. M., Estudo comparativo da análise de macrotextura pelas técnicas de difração de raios X e difração de elétrons retroespalhados. 2002. 85p. Dissertação (Mestrado) Instituto de Pesquisas Energéticas e Nucleares. São Paulo. 2002. 
SINGH, R.K.; SINGH, A.K. Evolution of texture during thermo-mechanical processing of Al-Mg-Si-Cu alloy. Scripta Materialia, vol.38, pp. 1299-1306, 1998.

SCHUMANN H. Metalographie 10. Auflage. VEB Deutscher Verlag für Grundstoffindustrie, pp. 385-389, Leipzig, 1980.

SLAMOVA M., KARLIK M., ROBAUT F., SLAMA P., VERON M., Differences in microstructure and texture of $\mathrm{Al}-\mathrm{Mg}$ sheets produced by twin roll continuous casting and by direct chill casting, Materials Characterization, vol. 49, pp. 231-240, 2003.

SPERRY P. R. Metallographic study of equilibrium relationships in $3 \mathrm{~S}$ aluminum alloy. Journal of Metals, vol.7, pp. 145-151, 1955.

TAKANOHASHI, R. Efeito do tamanho de grão inicial e de um recozimento intermediário na microestrutura e textura cristalográfica de aços elétricos. 2003. 183p. Dissertação (Mestrado) - Escola Politécnica, Universidade de São Paulo. São Paulo, 2003.

TANGEN, S.; SJØLSTAD, K.; NES, E.; FURU, T.; MARTHINSEN, K. The effect of precipitation on the recrystallization behavior of a supersaturated, cold rolled AA3103 aluminium alloy. Materials Science Forum, vols-396-402, pp. 469-474, 2002.

TRICIBAR R., JIN I., Rolling aspects of twin roll casting. Light Metals, pp. 1129-1143, 1999.

URIZ J. P. I., SALAS J. F., SANABRIA A. S., Recristalización de bandas de alumínio procedentes de colada continua em frio, Revista de Metalurgia, vol. 36, pp. 435-451, 2000.

VERLINDEN B.; WOUTERS P.; MCQUEEN H. J.; AERNOUDT E.; DELAY L.; CAUWENBERG S. Effect of different homogenization treatments on the hot workability of alloy AA2024, Materials Science and Engineering, vol. A123, pp.229, 1990. 
VIANA, C.S.; PAULA, A.S. Texturas de deformação. In: Textura e relações de orientação. A.P. Tschiptschin e outros (Editores), EPUSP, São Paulo, pp. 59-75, 2001.

VIEIRA C.; MAZZOLENIS S. A história do alumínio no Brasil, 30 anos Abal, São Paulo: Editora Antonio Belline, 2000. pp.120.

WEI M.; ZHI D.; BRANDON D. Analysis of C-axis textured $\alpha$-alumina by electron backscatter diffraction, The Americas Microscopy and Analysis, vol. 55, pp. 13-15, 2002.

WELCH P. I. An analysis of equibiaxial stretching texture in commercial killed steel, brass and aluminium. Zeitschrift für Metallkunde, vol. 73, pp. 381-386, 1982.

WESTENGEN H., Twin roll casting of aluminium, Light Metals, pp. 1111-1127, 2000.

WEVER F., Über die Walzstruktur kubisch kristallisierender Metalle, Zeitschrift für Physik, vol.28, pp. 69-90, 1924.

YUN M., LOKYER S., HUNT J. D., Twin roll casting of aluminum alloys, Materials Science and Engineering A, vol. 280, pp. 116-123, 2000.

ZENER, C. citado em: SMITH, C. S. Grains, phases and interfaces: an interpretation of microstructure. Transactions AIME, vol. 175, pp. 11-51, 1948.

ZHANG, D.F.; JIANG, X. P.; HU, Z.C.; WANG, F.; ZUO, F. Rolling and annealing texture of 3004 aluminium alloy. Materials Science Forum, vol. 408-412, pp. 1477-1482, 2002. 